$$
\text { ADRIANA PETRELLA HANSEN }
$$

ANÁLISE DO EFEITO EM TERMOS DE DESEMPENHO AMBIENTAL DA SUBSTITUIÇÃO DE ETENO DE ORIGEM FÓSSIL POR EQUIVALENTE RENOVÁVEL NA PRODUÇÃO DE POLIESTIRENO 



\section{ANÁLISE DO EFEITO EM TERMOS DE DESEMPENHO AMBIENTAL DA SUBSTITUIÇÃO DE ETENO DE ORIGEM FÓSSIL POR EQUIVALENTE RENOVÁVEL NA PRODUÇÃO DE POLIESTIRENO}

Dissertação apresentada à Escola Politécnica da Universidade de São Paulo como requisito necessário para a obtenção do título de Mestre em Engenharia

São Paulo 



\section{ANÁLISE DO EFEITO EM TERMOS DE DESEMPENHO AMBIENTAL DA SUBSTITUIÇÃO DE ETENO DE ORIGEM FÓSSIL POR EQUIVALENTE RENOVÁVEL NA PRODUÇÃO DE POLIESTIRENO}

Dissertação apresentada à Escola Politécnica da Universidade de São Paulo como requisito necessário para a obtenção do título de Mestre em Engenharia

Área de Concentração:

Engenharia Química

Orientador:

Prof. Dr. Luiz Alexandre Kulay 
Este exemplar foi revisado e corrigido em relação à versão original, sob responsabilidade única do autor e com a anuência de seu orientador.

São Paulo, de julho de 2013.

Assinatura do autor

Assinatura do orientador

FICHA CATALOGRÁFICA

Hansen, Adriana Petrella

Análise do efeito em termos de desempenho ambiental da substituição de eteno de origem fóssil por equivalente renovável na produção de poliestireno / A.P. Hansen. -- versão corr. -- São Paulo, 2013.

$227 \mathrm{p}$.

Dissertação (Mestrado) - Escola Politécnica da Universidade de São Paulo. Departamento de Engenharia Química.

1.Poliestireno 2. Ciclo de vida (Avaliação) I.Universidade de São Paulo. Escola Politécnica. Departamento de Engenharia Química II.t. 


\section{DEDICATÓRIA}

Dedico este trabalho a Deus por me proporcionar saúde e perseverança. 


\section{AGRADECIMENTOS}

Ao Prof. Dr. Luiz Alexandre Kulay registro meus sinceros agradecimentos, não só pela orientação digna, mas também por compartilhar sabedorias e por acreditar no meu potencial.

Aos meus pais, irmã e cunhado agradeço por entenderem a importância deste mestrado na minha vida.

Ao meu namorado, Pedro, pelo apoio e carinho.

Aos amigos do GP2, Alex e Rafael, pelos conhecimentos transmitidos que foram fundamentais para que eu pudesse concluir a disciplina obrigatória e demais etapas do mestrado.

Ao colega Eduardo, por me orientar e fornecer informações de relevância para o andamento da pesquisa.

Ao Prof. Gil Anderi, pelas palavras de estímulo e acolhimento.

À Petrobras S.A., pelo suporte técnico oferecido durante a análise crítica do relatório final da dissertação. 


\section{RESUMO}

O uso intensivo de petróleo tem sido matéria de discussões constantes por diferentes setores da sociedade, seja pela possibilidade de seu esgotamento ou pelos potenciais danos ambientais por ele ocasionados. Assim, com o intuito de minimizar os impactos gerados na produção de bens de consumo fundamentalmente constituídos por recursos fósseis, a indústria petroquímica se mobilizou no desenvolvimento de novas tecnologias. No que tange a produção de derivados poliméricos, a principal estratégia adotada nesse sentido está associada à substituição de petróleo por insumos manufaturados a partir de fontes renováveis. Esta solução visa tanto reduzir a extração dos recursos fósseis, quanto amenizar as emissões de gases efeito estufa. Entretanto, poucos são os estudos que avaliam os reais efeitos decorrentes desta medida, quantificando os impactos, positivos e negativos, ocasionados ao meio ambiente e ao homem. Diante deste fato, o presente trabalho tem por finalidade investigar os efeitos ambientais da substituição de eteno de origem fóssil por sucedâneo obtido via desidratação de etanol de cana-de-açúcar, no processo produtivo do poliestireno. $O$ atendimento de tal objetivo foi alcançado a partir da aplicação da técnica de Avaliação do Ciclo de Vida (ACV), cuja visão sistêmica permite analisar a influência da troca de matériasprimas para a produção de uma tonelada de poliestireno cristal (GPPS) e uma tonelada de poliestireno de alto impacto (HIPS), respectivamente. A abordagem possui uma abrangência do "berço-ao-portão da fábrica" e faz uso do método de avaliação $\operatorname{ReCiPe}(H)$ - Midpoint, versão 1.07. Considerando treze categorias de impacto, os resultados dos perfis de desempenho do GPPS e HIPS parcialmente renováveis apresentaram-se pior em: mudanças climáticas; acidificação terrestre; eutrofização; toxicidade humana; formação de oxidantes fotoquímicos e material particulado; ecotoxicidade terrestre e aquática; uso de solo agricultável e depleção de água; em resposta às atividades agrícolas para a produção de cana-de-açúcar. Por outro lado, os maiores consumos de gás natural e petróleo requeridos para a manufatura de eteno no sistema de produto do GPPS e HIPS fósseis, contribuíram para impactos relativamente superiores nas categorias de depleção de ozônio, transformação de solo natural e depleção de recursos fósseis.

Palavras-chave: Desempenho ambiental; poliestireno; recurso fóssil; recurso renovável; Avaliação do ciclo de vida. 


\begin{abstract}
The intensive use of oil has been a subject of constant discussion among different sectors of society, due to the fossil depletion and potential environmental damage caused by it. Therefore, in order to minimize impacts on the production of consumer goods made from fossil resources, the petrochemical industry has been developing new technologies. Regarding the production of polymer derivatives, the key strategy was to replace fossil assets by raw materials obtained from renewable resources, for the purpose of slowing down the extraction of crude oil, as well as balancing atmospheric emission of greenhouse gases. However, there are only few studies assessing the actual results of this solution, quantifying its positive and negative environmental impacts. Considering this scenario, this study aims to investigate the environmental effects associated to the replacement of ethylene produced from natural gas by ethylene obtained by sugarcane ethanol dehydration in the production of polystyrene. This study used the Life Cycle Assessment (LCA) methodology, which systemic view allows to analyze the influence of this substitution during the production of one ton of crystal polystyrene (GPPS) and one ton of high impact polystyrene (HIPS). The system boundary comprises a "cradle-to-gate" approach and uses ReCiPe Midpoint $(\mathrm{H}) \mathrm{V} 1.07$ method to analyze thirteen environmental impacts. Both GPPS and HIPS partially made from renewable resource presented unfavorable results in ten impacts categories: climate change, terrestrial acidification, eutrophication, human toxicity, photochemical oxidants formation, particulate matter formation, terrestrial and freshwater Ecotoxicity, agricultural land occupation and water depletion. This scenario can be assigned to sugarcane production activities. On the other hand, the higher consumption of natural gas and crude oil required for the manufacture of ethylene in the fossil GPPS and HIPS system boundary contributed to greater impacts in the categories of ozone depletion, natural land transformation and fossil depletion.
\end{abstract}

Keywords: Environmental performance; polystyrene; fossil resource; renewable resource; Life Cycle Assessment. 


\section{SUMÁRIO}

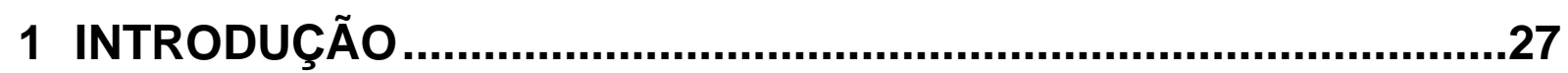

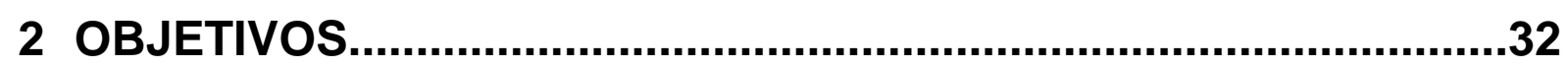

3 SUMÁRIO EXECUTIVO ................................................................33

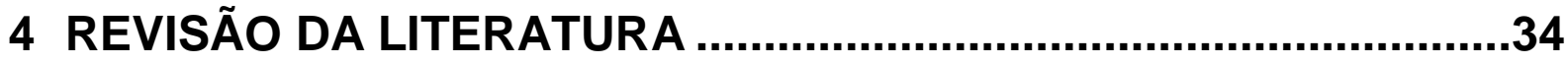

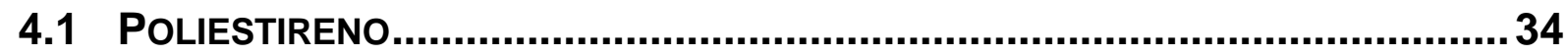

4.1.1 Caracterização, Histórico e Classificação do Poliestireno.........................34

4.1.2 Perspectivas do Mercado Mundial e Brasileiro ........................................36

4.1.3 Poliestireno: rota tecnológica petroquímica ………...............................38

4.1.3.1 Extracão de Petróleo e Gás Natural.......................................................38

4.1.3.1.1 Extração, pré-tratamento e bombeamento de Gás Natural......................39

4.1.3.1.2 Extração, pré-tratamento e bombeamento de Petróleo ...........................40

4.1.3.2 Refino de Petróleo ……………………………………………………....43

4.1.3.3 Produção de Intermediários ……………………………………………....47

4.1.3.3.1 Produção de eteno e benzeno ..........................................................48

4.1.3.3.2 Produção de Polibutadieno ……………………………....................5

4.1.3.4 Produção de Etilbenzeno ……………………………………………...51

4.1.3.5 Produção de Estireno …………………………………………………...52

4.1.3.6 Produção de Poliestireno ……………………………………………...53

4.1.4 Poliestireno: rota tecnológica via fonte renovável ................................55

4.1.4.1 Cultivo de Cana-de-açúcar.................................................................57

4.1.4.2 Produção de etanol hidratado a partir de cana-de-açúcar ........................60

4.1.4.3 Produção de eteno via etanol...............................................................62

4.1.4.3.1 Histórico da produção de eteno a partir de etanol...................................62

4.1.4.3.2 Produção de eteno a partir de etanol .................................................63

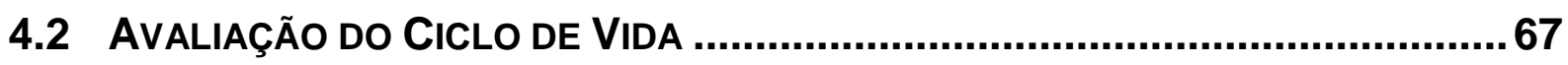

4.2.1 ACV: Conceito e Definição..................................................................69

4.2.2 Usos e aplicações ..............................................................................70

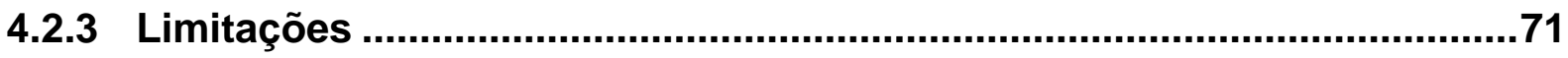

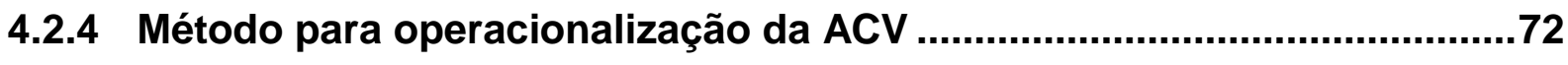

4.2.4.1 Definição de Objetivo e Escopo …………………………………………....73 
4.2.4.2 Análise de Inventário.....................................................................

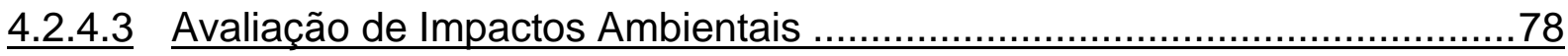

4.2.4.3.1 Seleção das categorias de impacto ............................................. 78

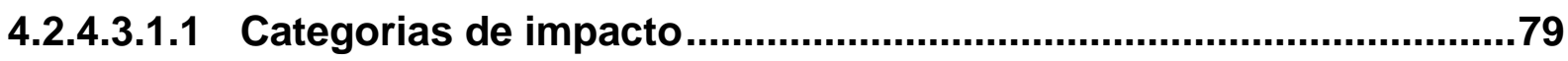

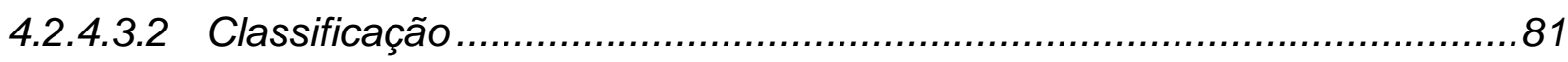

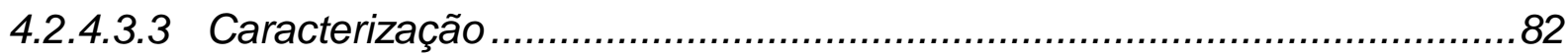

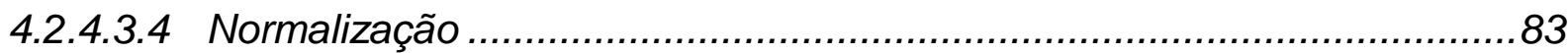

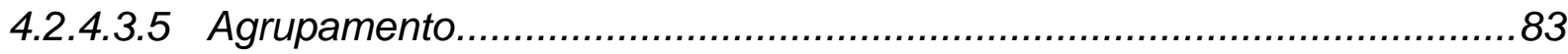

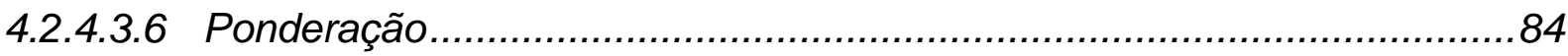

4.2.4.3.7 Métodos de Avaliação de Impactos Ambientais .................................... 85

4.2.4.3.7.1 CML - Center of Environmental Science ........................................85

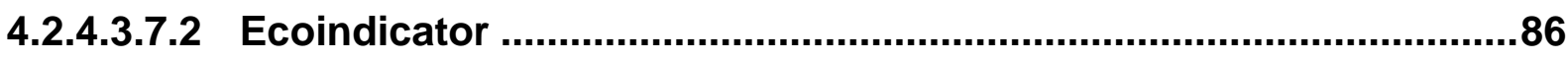

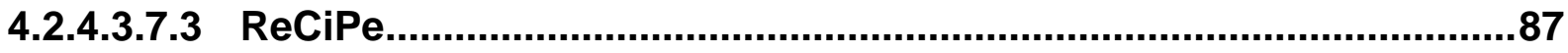

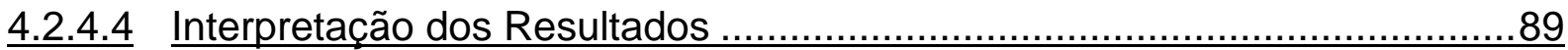

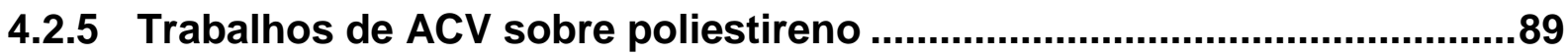

5 MÉTODO DE TRABALHO.............................................................95

6 ESTUDO DE ACV DO POLIESTIRENO .........................................97

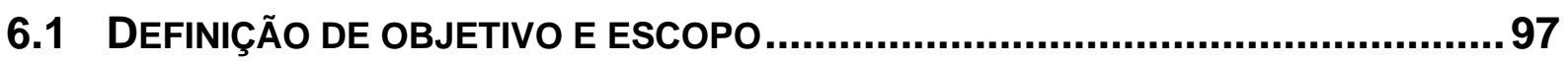

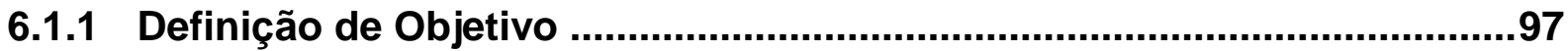

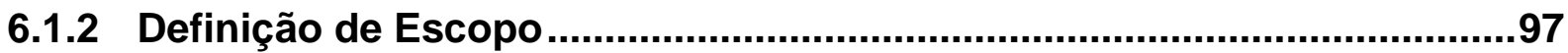

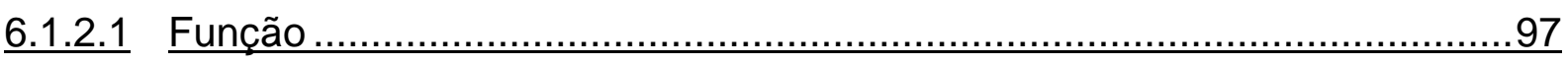

6.1.2.2 Unidade Funcional e Fluxo de Referência …………………………......98

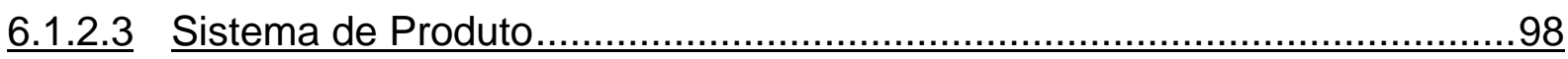

6.1.2.3.1 Poliestireno derivado exclusivamente de petróleo ….............................98

6.1.2.3.2 Poliestireno derivado parcialmente de fonte renovável......................... 100

6.1.2.4 Fronteiras do sistema de produto ...........................................................101

6.1.2.5 Cobertura tecnológica ........................................................................103

$\underline{6.1 .2 .6}$ Cobertura temporal ...................................................................104

6.1.2.7 Cobertura Geográfica...................................................................104

6.1.2.8 Requisitos de qualidade dos dados ...............................................105

6.1.2.9 Fonte dos dados ........................................................................105

$\underline{6.1 .2 .10}$ Procedimentos de alocação ...........................................................106

6.1.2.11 Exclusão de aspectos ambientais ......................................................106 
6.1.2.12 Método de Avaliação de Impacto e categorias de impacto ….................107

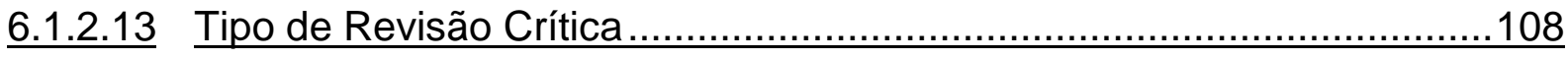

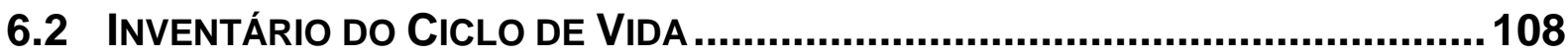

6.2.1 Subsistema de extração de petróleo ……...............................................108

6.2.1.1 Origem e procedência do petróleo ………...............................................109

6.2.1.2 Transporte do Petróleo Bruto .................................................................111

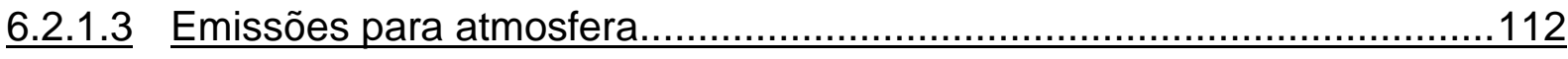

6.2.1.4 Emissões para o solo .....................................................................112

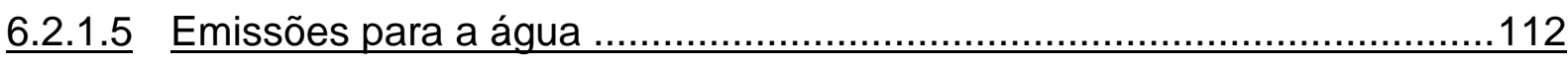

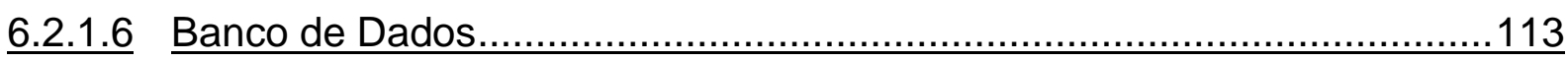

6.2.1.7 Inventário Consolidado da extração de petróleo nacional.........................114

6.2.1.8 Inventário Consolidado da extração de petróleo internacional..................116

6.2.2 Subsistema Extração de Gás Natural..................................................119

6.2.2.1 Determinação do percentual de Gás Natural Nacional e Importado .........119

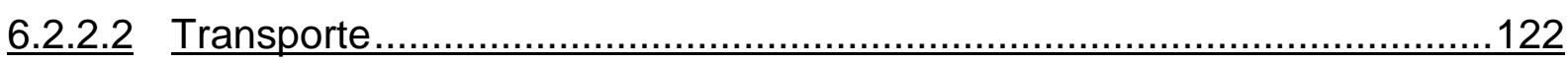

6.2.2.3 Emissões para atmosfera.................................................................123

6.2.2.4 Emissões para o solo ......................................................................124

6.2.2.5 Emissões para a água ……………………....................................124

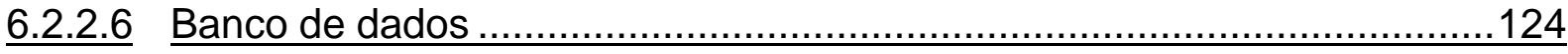

6.2.2.7 Inventário do Ciclo de Vida da Extração de Gás Natural .........................125

6.2.3 Subsistema Refino de Petróleo - Produção de Nafta .............................127

6.2.3.1 Critério de Alocação para os derivados de petróleo...................................129

6.2.3.2 Transporte de Nafta .......................................................................129

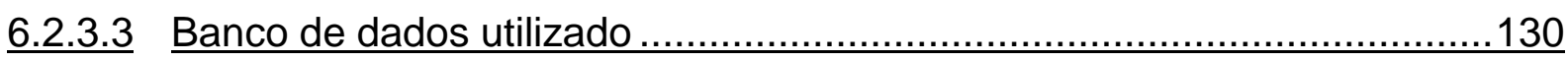

6.2.3.4 Características da Matriz Energética Brasileira .........................................130

6.2.3.5 Inventário do Ciclo de Vida do Refino de Petróleo ....................................131

6.2.4 Subsistema Produção de Eteno, Benzeno e Polibutadieno ....................132

6.2.4.1 Banco de Dados................................................................................133

6.2.4.2 Transporte de eteno e benzeno …………....................................... 134

6.2.4.3 Inventários do Ciclo de Vida do eteno e do benzeno ................................134

6.2.5 Subsistema Produção de Poliestireno ................................................141

6.2.5.1 Cobertura Tecnológica da produção de poliestireno ...................................142

6.2.5.1.1 Unidade complementar de vapor d'água ........................................ 142

6.2.5.2 Emissões para a atmosfera............................................................143 
6.2.5.3 Emissões para o solo .........................................................................

6.2.5.4 Emissões para a água ……………………...................................... 144

6.2.5.5 Banco de Dados........................................................................ 144

6.2.5.6 Inventário do Ciclo de Vida do GPPS e HIPS ..........................................145

6.2.6 Subsistema cultivo de cana-de-açúcar .............................................147

6.2.6.1 Área, produtividade e produção de cana-de-açúcar ...................................147

6.2.6.2 Área de Plantio e consumo de mudas ....................................................148

6.2.6.3 Aplicação de resíduos industriais no campo ….....................................148

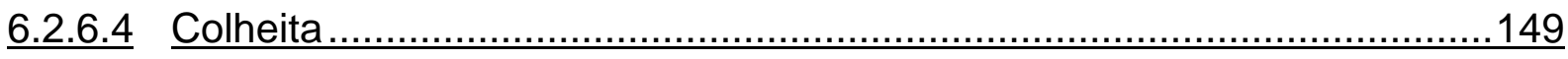

6.2.6.5 Consumo de calcário e gesso ……...................................................149

6.2.6.6 Consumo de fertilizantes minerais ...................................................... 150

6.2.6.7 Consumo de Pesticidas …………………........................................ 150

6.2.6.8 Equipamentos e consumo de Óleo Diesel ............................................151

6.2.6.9 Captura de Dióxido de Carbono e emissões atmosféricas ........................152

6.2.6.9.1 Emissões decorrentes da queima de óleo diesel ................................ 152

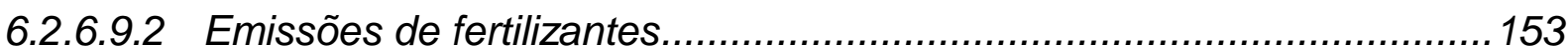

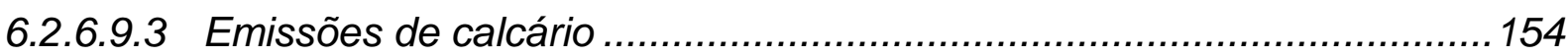

6.2.6.9.4 Emissões de resíduos industriais.................................................. 154

6.2.6.9.5 Emissões da queima de canavial....................................................154

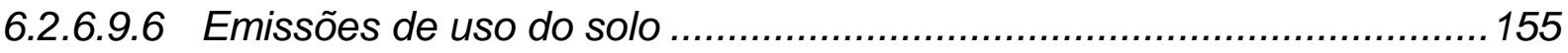

6.2.6.10 Emissões para o solo .....................................................................155

6.2.6.11 Emissões para a água …............................................................156

6.2.6.12 Transportes ..............................................................................157

6.2.6.13 Bancos de dados ......................................................................159

6.2.6.14 Inventário do Ciclo de Vida do cultivo de cana.....................................160

6.2.7 Subsistema Produção de Etanol Hidratado...........................................162

6.2.7.1 Cobertura Tecnológica.........................................................................162

6.2.7.2 Critério de Alocação ..........................................................................164

6.2.7.3 Transporte......................................................................................164

6.2.7.3.1 Transporte de insumos até a usina de etanol ................................... 165

6.2.7.3.2 Transporte etanol hidratado até a indústria de eteno............................166

6.2.7.4 Banco de Dados................................................................................ 167

6.2.7.5 Inventário do Ciclo de Vida da produção de Etanol Hidratado ...................167

6.2.8 Subsistema de Produção de Eteno a partir de Etanol ...........................168 
6.2.8.1 Características da Modelagem da Planta de Eteno ……............................169

6.2.8.1.1 Unidade de Desidratação de Etanol............................................... 170

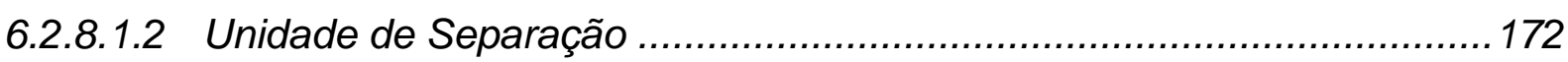

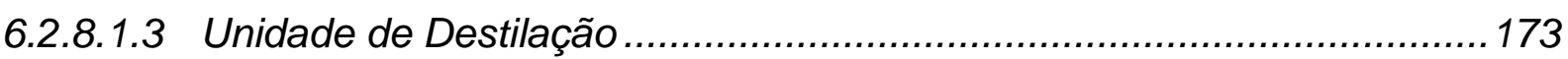

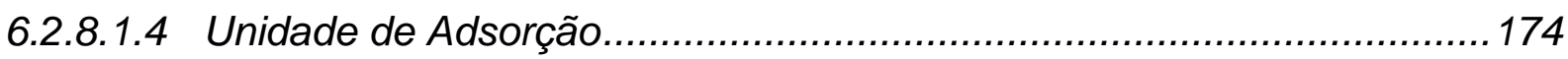

6.2.8.1.5 Unidade de Destilação Criogênica .....................................................175

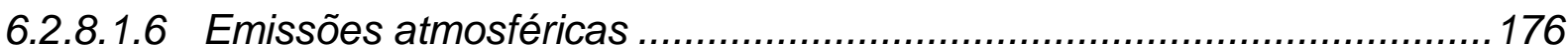

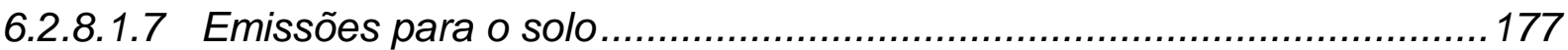

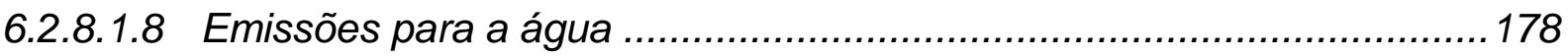

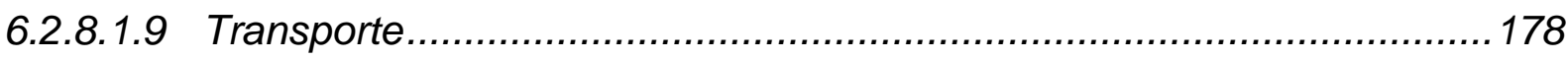

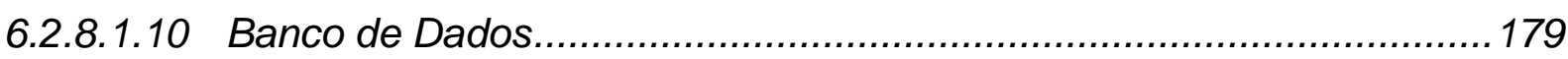

6.2.8.1.11 Inventário do Ciclo de Vida de Eteno a partir de Etanol......................179

7 RESULTADOS .........................................................................181

7.1 PerfiL de IMPacto ambiental do GPPS de ORIGem FósSiL E

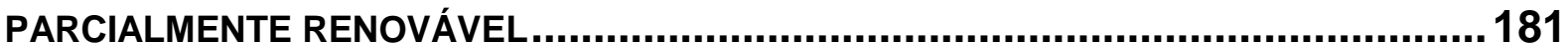

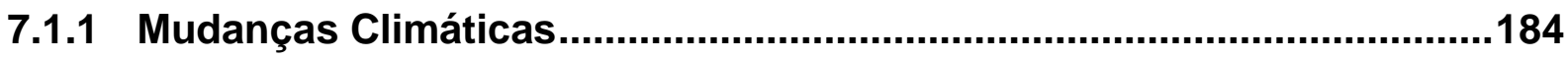

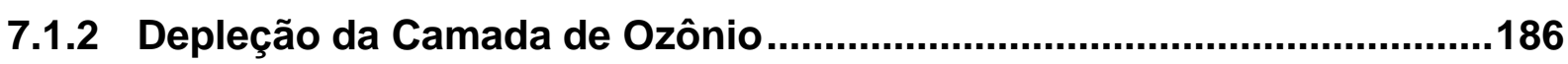

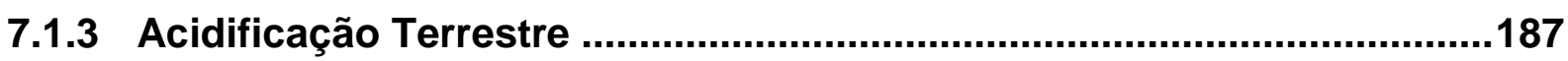

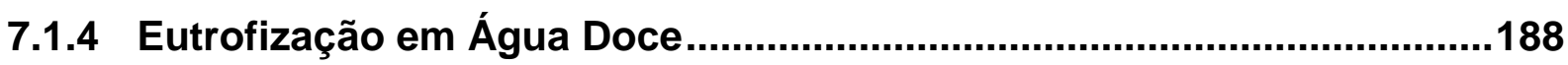

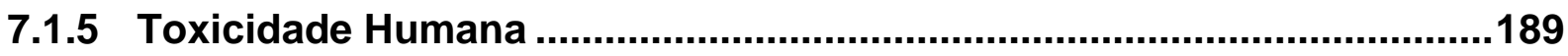

7.1.6 Formação de Oxidantes Fotoquímicos .................................................190

7.1.7 Formação de Material Particulado ........................................................191

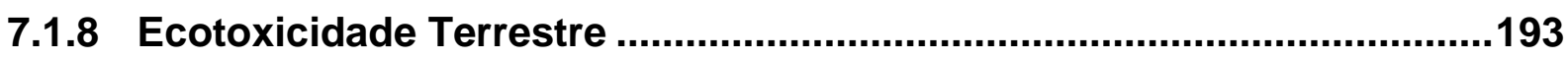

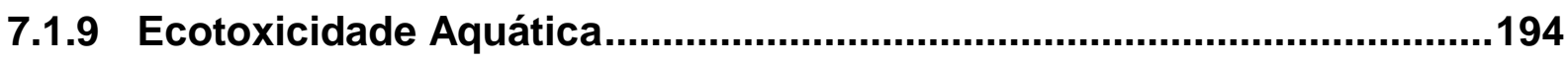

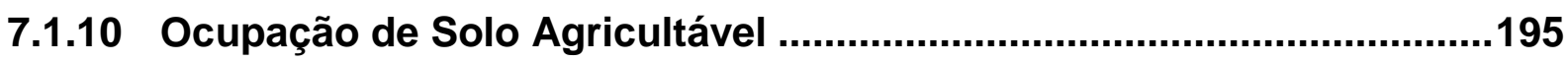

7.1.11 Transformação de Áreas Naturais .....................................................196

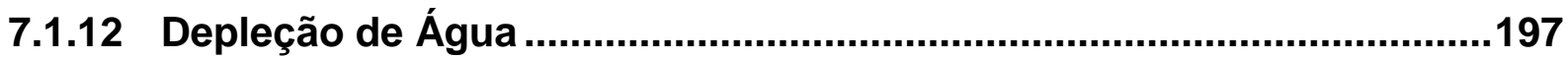

7.1.13 Depleção de Recurso Fóssil ..............................................................197

7.2 PeRfIL de IMPACTO AMBIENTAL DO HIPS DE ORIGEM FósSIL E

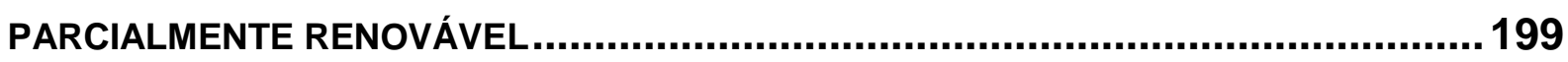

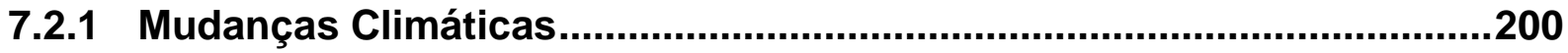

7.2.2 Depleção da Camada de Ozônio.........................................................202

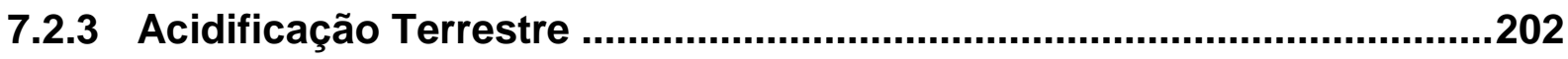




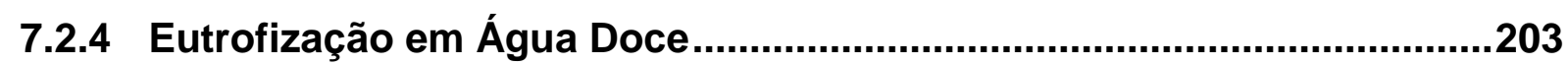

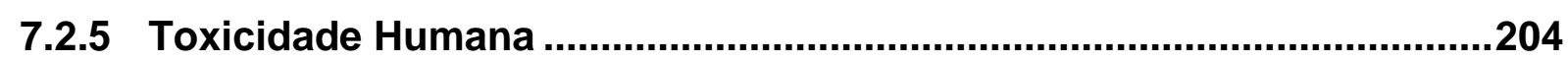

7.2.6 Formação de Oxidantes Fotoquímicos …...........................................205

7.2.7 Formação de Material Particulado.....................................................206

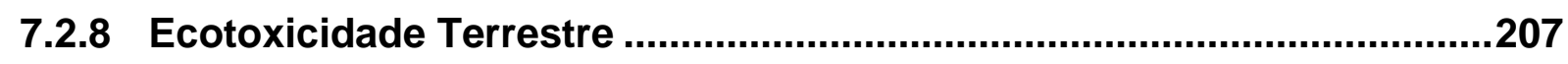

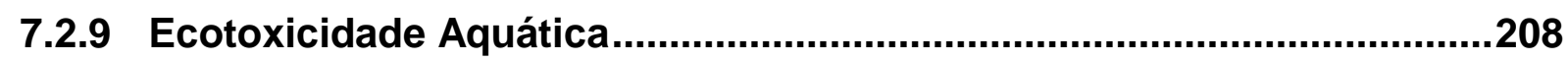

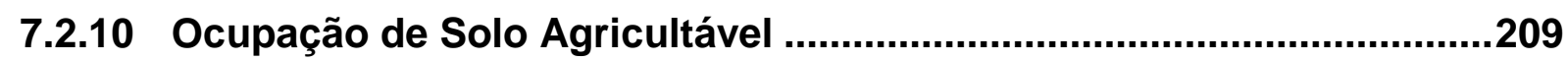

7.2.11 Transformação de Áreas Naturais ..................................................210

7.2.12 Depleção de Água ......................................................................211

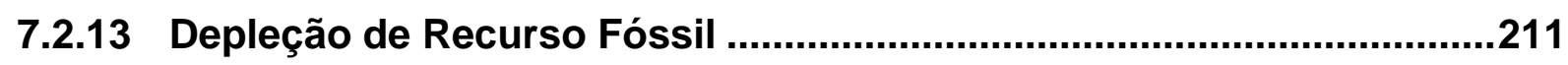

7.3 ANÁLISE COMPARATIVA ENTRE OS POLIESTIRENOS FÓSSEIS E PARCIALMENTE

RENOVÁVEIS - INDICADOR ENDPOINT ........................................................212

8 CONSIDERAÇÕES FINAIS ......................................................216

9 REFERÊNCIAS BIBLIOGRÁFICAS ........................................219 


\section{LISTA DE FIGURAS}

Figura 1: Sequência de operações relacionadas à produção de poliestireno a partir de ativos fósseis

Figura 2: Esquema do processo de Refino de Petróleo (adaptado de ANP, 2011). .45 Figura 3: Fluxograma simplificado de uma unidade de produção de poliestireno (Almeida, 2004). 54

Figura 4: Fluxograma da produção de poliestireno a partir de ativos fósseis e renovável .56

Figura 5: Estrutura típica da biomassa da cana-de-açúcar (BNDES, 2008). .57

Figura 6: Mapa de produção de cana-de-açúcar no Brasil (ÚNICA, 2012). .58

Figura 7: Fluxograma do processo de produção de etanol hidratado a partir de canade-açúcar ...... 60

Figura 8: Fluxograma do processo de produção de eteno a partir de etanol .65

Figura 9: Esquema da Análise de Ciclo de vida de um produto ..... .70

Figura 10: Estágios do estudo de ACV (adaptado da norma ABNT NBR ISO 14040, 2009). .73

Figura 11: Elementos da fase da AICV (ABNT, 2009) .78

Figura 12: Fluxograma esquemático da classificação dos aspectos em categorias de impacto (adaptado de UNEP, 2011).

Figura 13: Perfil de desempenho ambiental das embalagens de ovos a partir de papel reciclado e GPPS (ZABANIOTOU e KASSIDI, 2003).

Figura 14: Fluxograma do sistema de produto do poliestireno derivado exclusivamente de petróleo.

Figura 15: Fluxograma do sistema de produto do poliestireno derivado parcialmente de fonte renovável.

Figura 16: Modelo esquemático da malha de transporte de gás natural no Sistema Sudeste/Sul (CNI, 2010). 121

Figura 17: Gasodutos em operação (GASNET, 2013). 123

Figura 24: Produção de eteno a partir de etanol adotada para o desenvolvimento do ICV. 


\section{LISTA DE GRÁFICOS}

Gráfico 1: Produção, Importação e Exportação de nafta no Brasil - 2002 a 2011 (ANP, 2012).

Gráfico 2: Percentual de carga processada pela REFAP, segundo origem nacional e importada (ANP, 2011)

Gráfico 3: Percentual de carga processada pela REVAP, segundo origem nacional e importada (ANP, 2011) 128

Gráfico 4: Oferta Interna de Energia Elétrica por Fonte - 2011 (BEN, 2012).... 131

Gráfico 5: Comparação percentual dos desempenhos ambientais do GPPS fóssil e do GPPS parcialmente renovável. 183

Gráfico 6: Comparação percentual dos desempenhos ambientais do HIPS fóssil e do HIPS parcialmente renovável. 200

Gráfico 7: Avaliação de Impacto, em nível endpoint, para o GPPS fóssil e parcialmente renovável. 214

Gráfico 8: Avaliação de Impacto, em nível endpoint, para o HIPS fóssil e parcialmente renovável. 


\section{LISTA DE TABELAS}

Tabela 1: Capacidade Instalada (t/ano) de GPPS e HIPS no Brasil (ABIQUIM, 2010).

Tabela 2: Produção e vendas declaradas expressas em toneladas de GPPS e HIPS no Brasil (ABIQUIM, 2010).

Tabela 3: Importação e Exportação de GPPS e HIPS no Brasil (ABIQUIM, 2010)...37

Tabela 4: Produção de gás natural associado e não associado 2008-2011 (ANP, 2012)

Tabela 5: Composição elementar do gás natural associado e não associado (SANTOS, et. al., 2002).

Tabela 6: Composição elementar de óleos crus (FAHIN, AL-SAHHAF E ELKILANI, 2012).

Tabela 7: Produção de petróleo, por localização (terra e mar) e Unidades da Federação - 2010 (ANP, 2011). 41

Tabela 8: Produção de derivados de petróleo $\mathrm{m}^{3}$ - ano base 2010 (ANP, 2011) ....43

Tabela 9: Capacidade instalada de benzeno e eteno no Brasil (ABIQUIM, 2011) ...48

Tabela 10: Produção, Importação e Exportação de Nafta no Brasil (ANP, 2012) .....55

Tabela 11: Tipos de Transporte de cana - dados de 2005 (CTC, 2006 apud SEABRA, 2008).

Tabela 12: Relação entre as categorias midpoint e endpoint no método ReCiPe (GOEDKOOP, et al. 2013).

Tabela 13: Perfil de desempenho ambiental de 1000 embalagens de morango (MADIVAL et. al., 2009)

Tabela 14: Perfil de desempenho ambiental da produção de $1 \mathrm{~kg}$ de GPPS e $1 \mathrm{~kg}$ de HIPS (PlasticsEurope, 2008).

Tabela 15: Comparação entre a emissão de gases efeito estufa para os polímeros HIPS, GPPS e PLA - kg CO2eq/kg de polímero (adaptado de SUWANMANEE, 2010).

Tabela 16: Exploração de Petróleo Nacional (baseado em ANP, 2011). 109

Tabela 17: Produção de petróleo, por localização em mar, segundo Unidades da Federação - 2009-2010 (baseado em ANP, 2011). 
Tabela 18: Volume de carga processada importada, segundo país de origem - Média 2009 e 2010 (ANP, 2011)

Tabela 19: Distâncias de transporte marítimo do petróleo importado 112

Tabela 20: Bancos de dados utilizados para representar extração de petróleo importado

Tabela 21: Banco de dados adotados para os sistemas de transporte de petróleo cru

Tabela 22: Inventário da extração de $1 \mathrm{~kg}$ petróleo nacional - offshore. 114

Tabela 23: Inventário da extração de $1 \mathrm{~kg}$ petróleo onshore - Nigéria 116

Tabela 24: Inventário da extração de $1 \mathrm{~kg}$ petróleo onshore - Argélia 117

Tabela 25: Inventário da extração de 1 kg petróleo onshore - Arábia Saudita, Líbia e Iraque

Tabela 26: Volume de gás natural importado, produzido e consumido no Brasil - 2009 e 2010 (BEN, 2012)

Tabela 27: Importação de gás natural, segundo países de procedência - 2009 e 2010 (ANP, 2011)

Tabela 28: Média aritmética do percentual de contribuição do gás natural nacional e importado - 2009 e 2010.

Tabela 29: Oferta de gás natural, segundo os estados integrados ao estado do RS 2009 e 2010 (ANP, 2011).

Tabela 30: Referências da base de dados do Ecoinvent para a extração de gás natural.

Tabela 31: Inventário da extração de $1 \mathrm{~m}^{3}$ de gás natural - Brasil 125

Tabela 32: Inventário da extração de $1 \mathrm{~m}^{3}$ de gás natural - Bolívia 126

Tabela 33: Determinação para os fatores de alocação 129

Tabela 34: Inventário do refino de $1 \mathrm{~kg}$ de petróleo 131

Tabela 35: Modelagem utilizada do SimaPro para produção de intermediários 133

Tabela 36: Banco de dados adotados para os sistemas de transporte de petróleo cru

Tabela 37: Inventário da produção de $1 \mathrm{~kg}$ de eteno 135

Tabela 38: Inventário da produção de $1 \mathrm{~kg}$ de benzeno 136

Tabela 39: Inventário da produção de $1 \mathrm{~kg}$ de polibutadieno 137

Tabela 40: Inventário do Ciclo de Vida da unidade de produção de vapor - boiler à gás 
Tabela 41: Bancos de dados do Ecoinvent adotados na produção de poliestireno 144 Tabela 42: Inventário da produção de 1 t. GPPS 145

Tabela 43: Inventário da produção de 1 tonelada de HIPS 146

Tabela 44: Caracterização do esquema de plantio adotado no estudo (SUGAWARA, 2012). 148

Tabela 45: Caracterização do esquema de colheita adotada no estudo (SUGAWARA, 2012). 149

Tabela 46: Teor de nutrientes recomendado nos diferentes estágios da cana (SUGAWARA, 2012).

Tabela 47: Tipo e quantidade de fertilizantes aplicados (SUGAWARA, 2012) . ......150 Tabela 48: Teor de nutrientes recomendado nos diferentes estágios da cana (SUGAWARA, 2012).

Tabela 49: Consumo de óleo diesel por grupo de processos agrícolas da cana (FNP, 2010 apud SUGAWARA, 2012).

Tabela 50: Fatores de emissão para a queima de óleo diesel em maquinários agrícolas (NEMECEK e KAJI, 2007 apud SUGAWARA, 2012).

Tabela 51: Fatores de emissão para a queima de palha (GREET, 2010 apud SUGAWARA, 2012).

Tabela 52: Emissões estimadas de $\mathrm{CO} 2$ decorrentes do uso do solo pela cana-deaçúcar (SUGAWARA, 2012). 155

Tabela 53: Origem e teor de metais de pesados de produtos agrícolas utilizadas na cana-de-açúcar (SUGAWARA, 2012).

Tabela 54: Emissões de metais pesados para o solo pela cultura da cana-de-açúcar (SUGAWARA, 2012).

Tabela 55: Distâncias de transporte dos insumos agrícolas da cana-de-açúcar (SUGAWARA, 2012). 158

Tabela 56: Dados da operação de $1 \mathrm{~m}^{3}$ pelo sistema de aspersão da vinhaça (SUGAWARA, 2012). 159

Tabela 57: Bancos de dados do Ecoinvent adotados na produção de cana-de-açúcar (SUGAWARA, 2012).

Tabela 58: Inventário da produção de $1 \mathrm{~kg}$ de cana (SUGAWARA, 2012). 160

Tabela 59: Percentuais de Alocação de Etanol Hidratado e Açúcar 164 Tabela 60: Localização das unidades fornecedoras de insumos da produção de etanol hidratado. 165 
Tabela 61: Distâncias de transporte dos insumos da produção de etanol hidratado 166

Tabela 62: Distâncias de transporte do etanol hidratado até a indústria de eteno .. 167 Tabela 63: Banco de dados do Ecoinvent adotados na produção de etanol hidratado

Tabela 64: Inventário da produção de etanol hidratado a partir de 1 tonelada de canade-açúcar

Tabela 65: Composição das correntes de entrada e saída dos reatores catalíticos da produção de eteno renovável

Tabela 66: Composição das correntes da unidade de separação - produção de eteno renovável.

Tabela 67: Composição dos fluxos de entrada e saída da unidade de destilação produção de eteno renovável

Tabela 68: Composição das correntes de entrada e saída da unidade de adsorção produção de eteno renovável

Tabela 69: Composição das correntes de entrada e saída da unidade de destilação criogênica - produção de eteno renovável.

Tabela 70: Composição química dos efluentes líquidos da produção de eteno renovável.

Tabela 71: Banco de Dados adotado para a composição do subsistema de produção de eteno a partir de etanol.

Tabela 72: Inventário da produção de 1 tonelada de eteno a partir de etanol

Tabela 73: Perfil de Impacto Ambiental do GPPS fóssil e do GPPS parcialmente renovável.

Tabela 74: Principais aspectos ambientais contribuintes para a categoria de Mudanças Climáticas na produção de GPPS

Tabela 75: Principais aspectos ambientais contribuintes para a categoria de Depleção da Camada de Ozônio na produção de GPPS 186

Tabela 76: Principais aspectos ambientais contribuintes para a categoria de Acidificação Terrestre na produção de GPPS

Tabela 77: Principais aspectos ambientais contribuintes para a categoria de Eutrofização em Água Doce na produção de GPPS 188

Tabela 78: Principais aspectos ambientais contribuintes para a categoria de Toxicidade Humana na produção de GPPS. 
Tabela 79: Principais aspectos ambientais contribuintes para a categoria de Formação de Oxidantes Fotoquímicos de GPPS.

Tabela 80: Principais aspectos ambientais contribuintes para a categoria de Formação de Material Particulado na produção de GPPS

Tabela 81: Principais aspectos ambientais contribuintes para a categoria de Ecotoxicidade Terrestre na produção de GPPS 193

Tabela 82: Principais aspectos ambientais contribuintes para a categoria de Ecotoxicidade Aquática na produção de GPPS

Tabela 83: Principais aspectos ambientais contribuintes para a categoria de Ocupação de Solo Agricultável na produção de GPPS

Tabela 84: Principais aspectos ambientais contribuintes para a categoria de Transformação de Áreas Naturais na produção de GPPS 196

Tabela 85: Principais aspectos ambientais contribuintes para a categoria de Depleção de Água na produção de GPPS

Tabela 86: Principais aspectos ambientais contribuintes para a categoria de Depleção de Recurso Fóssil na produção de GPPS

Tabela 87: Perfil de Impacto Ambiental do HIPS fóssil e do HIPS parcialmente renovável.

Tabela 88: Principais aspectos ambientais contribuintes para a categoria de Mudanças Climáticas na produção de HIPS 201

Tabela 89: Principais aspectos ambientais contribuintes para a categoria de Depleção da Camada de Ozônio na produção de HIPS 202

Tabela 90: Principais aspectos ambientais contribuintes para a categoria de Acidificação Terrestre na produção de HIPS. 203

Tabela 91: Principais aspectos ambientais contribuintes para a categoria de Eutrofização em Água Doce na produção de HIPS. 204

Tabela 92: Principais aspectos ambientais contribuintes para a categoria de Toxicidade Humana na produção de HIPS 204

Tabela 93: Principais aspectos ambientais contribuintes para a categoria de Formação de Oxidantes Fotoquímicos de HIPS 205

Tabela 94: Principais aspectos ambientais contribuintes para a categoria de Formação de Material Particulado na produção de HIPS. 206

Tabela 95: Principais aspectos ambientais contribuintes para a categoria de Ecotoxicidade Terrestre na produção de HIPS 
Tabela 96: Principais aspectos ambientais contribuintes para a categoria de

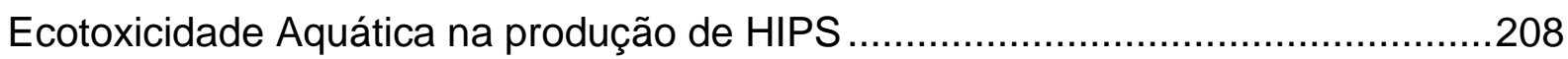
Tabela 97: Principais aspectos ambientais contribuintes para a categoria de Ocupação de Solo Agricultável na produção de HIPS 209 Tabela 98: Principais aspectos ambientais contribuintes para a categoria de Transformação de Áreas Naturais na produção de HIPS 210 Tabela 99: Principais aspectos ambientais contribuintes para a categoria de Depleção de Água na produção de HIPS. 211 Tabela 100: Principais aspectos ambientais contribuintes para a categoria de Depleção de Recurso Fóssil na produção de HIPS .212 Tabela 101: Resultados da Avaliação de Impacto, em nível endpoint, para o GPPS fóssil e parcialmente renovável. .213 Tabela 102: Resultados da Avaliação de Impacto, em nível endpoint, para o HIPS fóssil e parcialmente renovável. 


\section{LISTA DE ABREVIATURAS E SIGLAS}

$\left(\mathrm{C}_{2} \mathrm{H}_{5}\right)_{2} \mathrm{O} \quad$ Éter Etílico

ABIQUIM Associação Brasileira da Indústria Química

ABNT Associação Brasileira de Normas Técnicas

ACC Conselho de Química Americano

ACV Avaliação do Ciclo de Vida

AICV Avaliação de Impacto do Ciclo de Vida

AN Transformação de Áreas Naturais

ANP Agência Nacional do Petróleo, Gás Natural e Biocombustíveis

AT Acidificação Terrestre

BEN Balanço Energético Nacional

BNDES Banco Nacional de Desenvolvimento Econômico e Social

$\mathrm{C}_{2} \mathrm{H}_{4} \quad$ Eteno ou Etileno

$\mathrm{C}_{2} \mathrm{H}_{5} \mathrm{OH} \quad$ Acetaldeído

$\mathrm{C}_{2} \mathrm{H}_{6} \quad$ Etano

CENPES Centro de Pesquisas e Desenvolvimento da Petrobrás

CFC Clorofluorcarbono

CGEE Centro de Gestão de Estudos Estratégicos

$\mathrm{CH}_{3} \mathrm{COH}$ Etanol

$\mathrm{CH}_{3} \mathrm{COOH}$ Ácido Acético

$\mathrm{CH}_{4} \quad$ Metano

CMAI Chemical Market Associates Inc.

CNI Confederação Nacional da Indústria

CO Monóxido de carbono

$\mathrm{CO}_{2} \quad$ Dióxido de carbono

CONAB Companhia Nacional de Abastecimento

CSTR Reatores Contínuos Agitados

CTBE Laboratório Nacional de Ciência e Tecnologia do Bioetanol

DA Depleção de Água

$\mathrm{DBO}_{5}$ Demanda Bioquímica de Oxigênio

DF Depleção de Recurso Fóssil 


\begin{tabular}{ll} 
DO & Depleção da Camada de Ozônio \\
DQO & Demanda Química de Oxigênio \\
EA & Ecotoxicidade de Água Doce \\
EB & Etilbenzeno \\
EH & Efluentes Hídricos \\
EPE & Empresa de Pesquisa Energética \\
ET & Ecotoxicidade Terrestre \\
ETE & Estação de Tratamento de Efluentes \\
EU & Eutrofização \\
FCC & Craqueamento em Leito Fluidizado \\
GASBOL & Gasoduto Bolívia-Brasil \\
GEE & Gás de Efeito Estufa \\
GLP & Gás Liquefeito de Petróleo \\
GPPS & Poliestireno Cristal \\
$\mathrm{H}_{2}$ & Hidrogênio \\
$\mathrm{H}_{2} \mathrm{O}$ & Água \\
HC & Hidrocarbonetos \\
HIPS & Poliestireno de Alto Impacto \\
ICV & Inventário de Ciclo de Vida \\
IPCC & Intergovernmental Panel on Climate Change \\
ISO & International Organization for Standardization \\
MC & Mudanças Climáticas \\
MDIC & Ministério do Desenvolvimento, Indústria e Comércio Exterior \\
MHE & Ministerio Hidrocarburos y Energía \\
MME & Ministério de Minas e Energia \\
MP & Material particulado \\
$\mathbf{N}_{2} O$ & Óxido de dinitrogênio \\
NH & Amônia \\
NMVOC & Compostos Orgânicos Voláteis Não-Metano \\
NO ${ }_{3}^{-}$ & Nitrato \\
NOx & Óxidos de enxofre \\
OF & Formação de Oxidantes Fotoquímicos \\
ONG & Organização Não Governamental \\
& \\
\hline
\end{tabular}




$\begin{array}{ll}\text { ONS } & \text { Operador Nacional de Sistema Elétrico } \\ \text { OSCAN } & \text { Oleoduto Osório-Canoas } \\ \text { PBD } & \text { Polibutadieno } \\ \text { PET } & \text { Politereftalato de etileno } \\ \text { PLA } & \text { Plástico Polilático } \\ \text { PM } & \text { Material Particulado } \\ \text { PO } 4 & \text { Fosfato } \\ \text { PS } & \text { Poliestireno } \\ \text { REDUC } & \text { Refinaria Duque de Caxias } \\ \text { REFAP } & \text { Refinaria Alberto Pasqualini } \\ \text { REPA } & \text { Resource Environmental Profile Analysis } \\ \text { REVAP } & \text { Refinaria Henrique Lages } \\ \text { RLAM } & \text { Refinaria Landulpho Alves } \\ \text { SA } & \text { Ocupação de Solo Agricultável } \\ \text { SESMA } & \text { Setor de Segurança, Saúde e Meio Ambiente } \\ \text { SETAC } & \text { Society of Environmental Toxicology and Chemistry } \\ \text { SF6 } & \text { Hexafluoreto de enxofre } \\ \text { SICECORS } & \text { Sistema Centralizados de Controle de Resíduos Sòlidos } \\ \text { SIGEA } & \text { Sitema de Gestão de Emissões Atmosféricas da Petrobrás } \\ \text { SIN } & \text { Sistema Interligado Nacional } \\ \text { SITEL } & \text { Sistema Inegrado de Tratamento de Efluentes Líquidos } \\ \text { SM } & \text { Estireno } \\ \text { SO } 2 & \text { Dióxido de enxofre } \\ \text { SOx } & \text { Óxidos de enxofre } \\ \text { SST } & \text { Sólidos Suspensos Totais } \\ \text { TEDUT } & \text { Terminal Marítimo Almirantes Soares Dutra } \\ \text { TH } & \text { Toxicidade Humana } \\ \text { TKN } & \text { Total Kjeldahl Nitrogen } \\ \text { TSP } & \text { Superfosfato triplo } \\ \text { UF } & \text { Unidade Funcional } \\ \text { UNEP } & \text { United Nations Environment Programme } \\ \text { ÚNICA } & \text { União da Indústria de Cana-de-açúcar } \\ \text { UPGN } & \text { Unidades de Processamento de Gás Natural } \\ & \end{array}$


VOC Compostos Orgânicos Voláteis

WMO Organização Meteorológica Mundial 


\section{INTRODUÇÃO}

As consequências do uso desregrado dos recursos naturais na manutenção do atendimento das necessidades humanas tem estimulado extensos debates relacionados a matéria ambiental nas últimas quatro décadas. A possibilidade de aumento da temperatura média do planeta resultante da emissão de gases efeito estufa, a acidificação da chuva, o possível esgotamento de recursos abióticos, dentre outros impactos ambientais intensificados por ações antrópicas, são alguns dos motivos pelos quais a sociedade passou a discutir sobre a influência adversa de seu modelo de desenvolvimento, perante a qualidade do meio ambiente presente e futura. Sob o viés histórico, tal reflexão teve início com a crise de petróleo da década de 1970. Neste momento, questionava-se a relação entre a demanda de bens e a capacidade de suporte do meio ambiente em reaver a sua condição de equilíbrio, já que demandado extensivamente pelas atividades humanas. Assim, em primeira instância, estudos propunham o desenvolvimento de análises energéticas de produtos, com o intuito de quantificar consumos, em detrimento às reservas naturais de fontes não renováveis de energia até então conhecidas. Mais adiante, na década de 1980, tais trabalhos ampliaram seu enfoque para quantificar o volume de matérias-primas necessário para a produção de um bem e as perdas relacionadas às transformações do processo.

Em decorrência dessas discussões, algumas pesquisas incorporaram análises comparativas entre diferentes materiais que desempenhavam mesmo uso ao fornecedor final. Destaca-se nessa temática, o questionamento sobre a adoção do plástico para embalagens, tendo em vista a crise do recurso energético base de sua constituição, em comparação ao uso de papel.

Paralelamente, a sociedade, em todas as suas dimensões, passou a interrogar a influência do consumo de petróleo, tanto para fins energéticos como não energéticos, no aumento da emissão de poluentes atmosféricos. Além disso, a possibilidade de esgotamento desse recurso inflamava a procura por substitutos do petróleo como matéria-prima para a indústria química. Atualmente, essa problemática ainda permeia o setor.

No Brasil, a crescente demanda por plásticos nas últimas décadas impulsionou o setor de petroquímicos básicos no aumento da produção de seus produtos, dentre eles o 
eteno. Consequentemente, a demanda por estes compostos estimulou o setor de derivados não energéticos, no que tange à oferta de nafta - principal matéria-prima da indústria petroquímica na produção de eteno e propeno.

Como evidência numérica deste cenário, tem-se o fato da produtividade de nafta em território nacional estar aquém da demanda do mercado brasileiro. Segundo a Agência Nacional de Petróleo (2012), dentre os derivados não energéticos, a nafta se sobressaiu, representando $23,5 \%$ das importações no ano de 2011 . Além disso, de 2007 a 2011, a importação da nafta passou por uma crescente representatividade ante o total de nafta oferecido no país, conforme corrobora o Gráfico 1 abaixo.

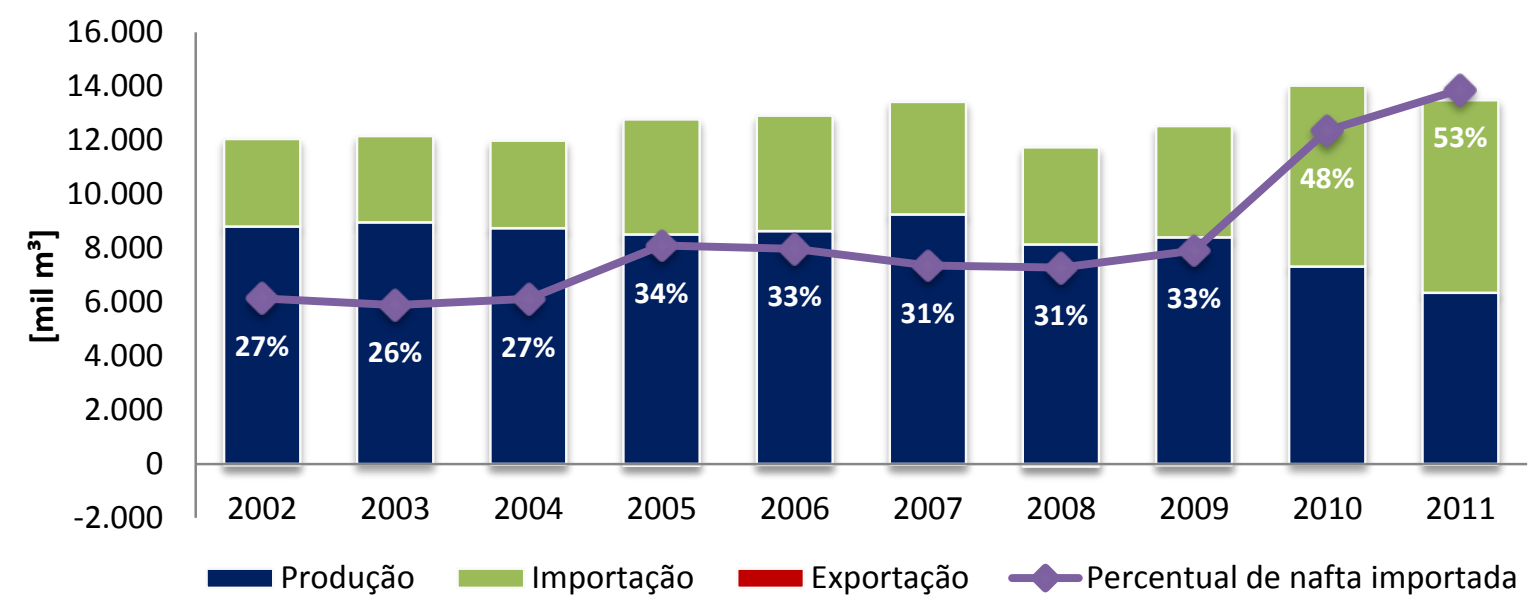

Gráfico 1: Produção, Importação e Exportação de nafta no Brasil - 2002 a 2011 (ANP, 2012).

O notório déficit de disponibilidade de matéria-prima brasileira para a fabricação de petroquímicos básicos estimulou a busca por tecnologias de transformação que viabilizassem a adoção de recursos renováveis na produção de bens de consumo.

Aliado a este esforço, tem-se também a crença de que tal mudança de matéria-prima possa melhorar a sustentabilidade ambiental do setor petroquímico, minimizando a sua geração de gases efeito estufa e sulfurados.

No âmbito nacional, este posicionamento assume duas frentes. A primeira visa a substituição do petróleo como fonte energética, a partir do desenvolvimento de combustíveis derivados a partir de cana-de-açúcar, dendê, mamona, dentre outras fontes vegetais.

Já a segunda frente objetiva suprimir a demanda de recursos petroquímicos não energéticos por fontes renováveis, na obtenção de produtos básicos do setor. 
O resultado desta percepção impulsionou, assim, a consolidação de rotas tecnológicas de produção de eteno derivado de fontes renováveis no país. $\mathrm{E}$, a partir deste, instituiu-se uma nova linha de plásticos nacionais, denominados de "polietileno verde", no qual parte da matéria-prima advém de cana-de-açúcar.

Em termos produtivos, a capacidade instalada de manufatura de eteno via etanol é, atualmente, da ordem de 200 mil t/ano. Contudo, esta produção tende a quadriplicar nos próximos cinco anos, com a instalação de novas unidades fabris (ABIQUIM, 2011).

O motivo pelo qual novas indústrias estão buscando fontes alternativas de matériaprima está pautado em três grandes questões: (i) diminuta oferta de recursos petroquímicos convencionais; (ii) custo de importação desses recursos; e (iii) o marketing ambiental positivo decorrente de uma mudança de comportamento do setor. Entretanto, apesar dos incentivos diretos e indiretos à adoção de recursos renováveis, outros plásticos de origem fundamentalmente fóssil ainda não incorporaram à cadeia de suprimentos produtos químicos intermediários derivados de cana-de-açúcar. Este panorama é constatado, por exemplo, nas indústrias produtoras de poliestireno.

O poliestireno é uma resina termoplástica amplamente utilizada nos segmentos de eletrodomésticos, informática, construção civil e embalagens alimentícias, o que faz deste um material presente nas atividades cotidianas. A sua demanda, seja global ou nacionalmente, acompanha a tendência de crescimento identificada no setor de plásticos. Nesse sentido, estima-se que 23 milhões de toneladas de poliestireno serão consumidas mundialmente em 2020, da quais cerca de 500 mil toneladas estarão centradas no mercado brasileiro.

O que faz do poliestireno uma resina de ampla utilização são as suas características físico-químicas. Estas, por sua vez, são específicas para cada classe de produtos: poliestireno cristal; poliestireno expandido; e, poliestireno de alto impacto.

O poliestireno cristal caracteriza-se por possuir aspecto brilhante e boa estabilidade dimensional, enquanto que o poliestireno de alto impacto possui maior tenacidade e ductilidade devido à incorporação de borracha na sua composição. Já o poliestireno expandido é conhecido por sua leveza, rigidez e baixa condutividade térmica.

Até o momento, pesquisas indicam que os poliestirenos ofertados no mercado não possuem qualquer componente de origem renovável, tal como outros plásticos. Não obstante, a previsão de crescimento da oferta de eteno via cana-de-açúcar induz, 
positivamente, o setor de resinas termoplásticas na incorporação de insumos desta natureza.

Com o aumento da produção de eteno renovável, duas problemáticas do setor estariam parcialmente sanadas. Ou seja, os custos de importação e escassez de nafta seriam substituídos pela oferta de insumos derivados da indústria sucroalcooleira. Por outro lado, os reais efeitos ocasionados pela substituição de eteno de origem fóssil por matéria-prima renovável no desempenho ambiental da produção de poliestireno ainda seriam uma incógnita para o setor.

Sob o viés ambiental, essa ação se reverte em potenciais benefícios quando comparada a condição original, em virtude do uso de ativos renováveis que promovem a retirada de gás carbônico presente na atmosfera para a constituição da matéria vegetal. No entanto, são aspectos inerentes e compulsórios da mesma atividade agrícola, o uso e a transformação do solo, bem como o consumo indireto de fontes não renováveis via insumos agrícolas.

O enfoque sistêmico dos malefícios e benefícios dessa substituição de recursos passa, então, a requerer uma visão holística sobre o ciclo de vida do bem em estudo. A partir dessa abordagem, é possível identificar as consequências ambientais de ações e estratégias além da fronteira do processo de transformação, evitando que uma possível solução transfira cargas ambientais entre diferentes impactos, regiões ou até mesmo entre receptores, ou seja, meio ambiente e saúde humana. Nesse cenário, a inclusão de etapas como extração de recursos, distribuição, uso, manutenção e descarte final do produto é intrínseca a análise. Tais características metodológicas adicionadas ao levantamento quantitativo dos impactos ambientais relacionados ao exercício da função de um produto são a base essencial da técnica de Avaliação de Ciclo de Vida (ACV).

Assim, a ACV permite entender as interações que ocorrem no ciclo de vida de um produto, processo ou serviço com o meio ambiente, possibilitando: identificar oportunidades para a melhoria de desempenho ambiental relativa a mudanças de processos, produtos e insumos; obter rótulos e declarações ambientais; e, comparar desempenhos ambientais de produtos cujo uso final ao consumidor atende a uma necessidade comum.

Esta última aplicação da metodologia justifica seu amplo uso nos estudos até hoje desenvolvidos para as análises ambientais de substituição de petróleo mediante outras matérias-primas. Nesta perspectiva, tem-se trabalhos de comparação de 
desempenho ambiental entre diesel e biodiesel, gasolina e etanol, dentre outros com viés na substituição de fontes energéticas. Em contrapartida, são recentes e em baixo número os estudos que visam quantificar os impactos ambientais relacionados a esta mesma estratégia na produção de bens não energéticos de petróleo.

Por tais motivos, o presente trabalho acadêmico utiliza a técnica da ACV para o estudo do poliestireno totalmente derivado de petróleo e do poliestireno de fonte parcialmente renovável. Desta forma, pretende-se averiguar as consequências da substituição de recursos fósseis por renováveis no perfil de desempenho ambiental do poliestireno, fornecendo dados quantitativos à indústria petroquímica sobre esta estratégia, de forma a viabilizar comparações entre os resultados obtidos com avaliações já desenvolvidas em mercados internacionais. 


\section{OBJETIVOS}

O objetivo deste estudo consiste em investigar o efeito em termos de desempenho ambiental da substituição de insumos de origem fóssil por homólogos, derivados de fonte renovável, na produção de poliestireno cristal (GPPS) e de alto impacto (HIPS).

Como objetivos complementares, porém não menos importantes, decorrentes desta iniciativa, pretende-se ainda:

- Proporcionar à indústria petroquímica um perfil quantitativo dos impactos ambientais associados à produção dos bens supramencionados, com grau de precisão, consistência e aprofundamento suficientes para permitir incorporar a variável ambiental a processos gerenciais de tomada de decisão;

- Contribuir para a ampliação do Banco de Dados brasileiro para suporte a estudos de Avaliação de Ciclo de Vida. 


\section{SUMÁRIO EXECUTIVO}

A fim de proporcionar ao leitor o melhor entendimento das reflexões empreendidas neste estudo, o mesmo foi estruturado da seguinte forma: Capítulo 4 - Revisão de Literatura, em que apresenta-se o poliestireno quanto às suas propriedades, aspectos de mercado e rotas tecnológicas de manufatura. O mesmo capítulo, trata ainda de apresentar a técnica de Avaliação de Ciclo de Vida (ACV), seus usos, aplicações e características. A Revisão de Literatura se encerra com uma digressão sobre estudos recolhidos na literatura dedicados a avaliação de desempenho ambiental de poliestireno.

No Capítulo 5 - Método de Trabalho aparecem descritos os passos que foram cumpridos no sentido de atender aos objetivos propostos para o estudo. Segue-se a este, o Capítulo 6 - Estudo de ACV do Poliestireno, que traz as bases conceituais que foram estabelecidas para o desenvolvimento da avaliação de ciclo de vida dos poliestirenos sob análise. Os produtos deste esforço de pesquisa encontram-se registrados mais adiante no Capítulo 7 - Resultados e Discussão, em associação com as reflexões analíticas que os mesmos puderam proporcionar.

Um extrato desta análise, construído no sentido de responder às perguntas ocultas por detrás dos objetivos estabelecidos no trabalho, encontra-se redigido no Capítulo 8 de Considerações Finais. Este arrazoado se completa com uma lista das Referências Bibliográficas (Capítulo 9) que consubstanciaram o estudo, a qual foi preparada de maneira a dar o devido crédito aos autores consultados para o suporte conceitual desta obra, bem como para permitir ao leitor recuperar as informações e conceitos tratados na dissertação. 


\section{REVISÃO DA LITERATURA}

Este capítulo discorre sobre o estado da arte das rotas tecnológicas de produção de poliestireno cristal e de alto impacto, bem como descreve os mecanismos de produção de eteno a partir de fonte renovável e a técnica da Avaliação do Ciclo de Vida.

No que se refere ao eteno derivado de fonte renovável, a pesquisa estendeu-se para a produção brasileira de cana-de-açúcar e etanol, elementos necessários para a sua manufatura.

\subsection{Poliestireno}

\subsubsection{Caracterização, Histórico e Classificação do Poliestireno}

O poliestireno é uma resina termoplástica inodora, incolor, insípida e rígida (EPA, 2012), resultante do processo de polimerização do estireno, tal como mostra a Equação 1 indicada a seguir.

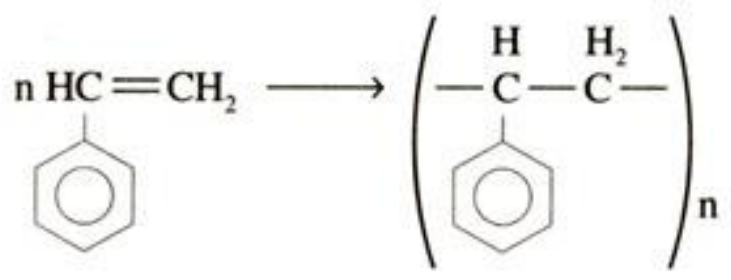

Borrelly (2002) explica que o poliestireno é um polímero comum, em que o número de unidades repetidas de estireno, indicado pelo índice $\mathbf{n}$, pode atingir valores em torno de 1000.

O primeiro relato sobre a descoberta da resina de poliestireno data de 1839 , na Alemanha, quando o químico Eduard Simon conseguiu isolar uma substância de aspecto incolor após destilar uma resina gomosa com vapor (Wünsch, 2000).

Conforme Almeida (2004) expõe, várias décadas se passaram entre a descoberta e a produção comercial do poliestireno, devido à falta de tecnologia para a manufatura de estireno em grandes quantidades. 
Assim, somente na década de 1930, pesquisadores da Dow Chemical Company desenvolveram um inibidor químico capaz de produzir estireno com elevado grau de pureza, viabilizando a produção de poliestireno de qualidade em escala comercial.

Como consequência dessa descoberta, as primeiras indústrias foram instaladas naquela mesma década na Alemanha e nos Estados Unidos respectivamente. (SERFATY e MONTENEGRO, 2002).

O aprimoramento da tecnologia de manufatura, aliado a redução de custos de fabricação e às propriedades físico-químicas de baixa condutividade, transparência, leveza e resistência, fizeram do poliestireno o quarto termoplástico de maior produção e consumo na década de 1990 (Corazza, 1995 apud Borrelly, 2002).

Ressalta-se que a ampla possibilidade de aplicação do material nos setores de embalagens, eletrônicos, bens de consumo, materiais de construção, transporte e mobiliários também foi responsável pela difusão do poliestireno mundialmente.

Assim, em resposta às necessidades do mercado, o poliestireno foi adaptado, passando a constituir três classes de produtos: poliestireno cristal; poliestireno expandido; e, poliestireno de alto impacto.

O poliestireno cristal, ou general purpose polystyrene (GPPS), é obtido via polimerização de estireno e caracteriza-se por possuir aspecto brilhante e boa estabilidade dimensional, além de ser um polímero originalmente incolor e rígido (ARAUJO, 2006). Sua principal aplicação se dá na manufatura de embalagens alimentícias, materiais descartáveis transparentes e produtos de escritórios.

O poliestireno expandido, conhecido por sua leveza e rigidez, é resultante da expansão da resina de poliestireno a partir de hidrocarbonetos criogênicos. Essas características, associadas à baixa condutividade térmica, justificam a aplicabilidade do material em sistemas de isolamento e embalagens diversas (ARAUJO, 2006).

Por fim, o poliestireno de alto impacto, ou high impact polystyrene (HIPS) é derivado da polimerização do monômero de estireno junto ao polibutadieno, em geral na presença de peróxidos. A incorporação de borracha ao poliestireno altera suas propriedades mecânicas, proporcionando maior tenacidade e ductilidade. Por outro lado, a transparência do material acaba por ser reduzida em decorrência da mesma ação (FORTE e DAL PIZZOL, 2001).

Entre as aplicações do HIPS, destacam-se a fabricação de embalagens de proteção contra choque, artigos descartáveis, peças de refrigeradores, eletroeletrônicos, entre outros. 


\subsubsection{Perspectivas do Mercado Mundial e Brasileiro}

Com base nos dados da Chemical Market Associates Inc. (CMAI, 2011), cerca de 60\% do estireno produzido no mundo em 2010 foi aplicado como matéria-prima para a produção de poliestireno. Já o restante destinou-se a manufatura de resinas e borrachas.

Estimativas feitas no mesmo período projetam que a demanda de poliestireno e poliestireno expandido deverá alcançar uma Taxa Anual de Crescimento Composta ${ }^{1}$ de 4,7\% até 2020. Em termos absolutos, isso corresponde a mais de 23 milhões de toneladas consumidas de poliestireno (GLOBAL BUSINESS INTELLIGENCE, 2012). No Brasil, a aplicação do estireno segue a tendência mundial, com prevalência de uso para fabricação de poliestireno e resinas termoplásticas (44\%), ao que se seguem a produção de resinas sintéticas (34\%) e borrachas (9\%).

Segundo levantamentos realizados pela ABIQUIM (2010), a manufatura de poliestireno e poliestireno expandido ultrapassou a marca de 510 mil toneladas em 2009. Destas, exatas 456 mil toneladas corresponderam a GPPS e a HIPS e as outras 68 mil toneladas, a poliestireno expandido. De acordo com a mesma fonte as manufaturas de GPPS e HIPS estão centralizadas nas empresas Dow Brasil S.A., Innova S.A., Unigel Plásticos S.A. e Videolar S.A., cujas capacidades instaladas estão apresentadas na Tabela 1.

Entre os anos de 2005 e 2009, a Taxa Anual de Crescimento Composta para a produção de HIPS e GPPS no mercado nacional foi de 2,7\%. Mantido este ritmo é possível projetar uma produção da ordem de 471 mil toneladas anuais de HIPS e GPPS para o país em 2020.

Tabela 1: Capacidade Instalada (t/ano) de GPPS e HIPS no Brasil (ABIQUIM, 2010).

\begin{tabular}{lcc}
\hline Empresa & Localização & $\begin{array}{c}\text { Capacidade Instalada (t) } \\
\text { Ano base: } \mathbf{2 0 0 9}\end{array}$ \\
\hline Dow Brasil S.A. & SP & 190.000 \\
Innova S.A. & RS & 146.000 \\
\hline Unigel Plásticos S.A. & SP & n.d. \\
Videolar S.A. & AM & 120.000 \\
\hline Total & & $\mathbf{4 5 6 . 0 0 0}$ \\
\hline
\end{tabular}

\footnotetext{
${ }^{1}$ A Taxa Anual de Crescimento Composta é definida pela taxa geométrica de crescimento em um dado período de tempo. Nesse conceito, entende-se que o crescimento ocorre de forma uniforme durante o período em análise.
} 
A Tabela 2 a seguir traz dados atualizados de produção e vendas destas mesmas modalidades de poliestireno para o país. No período de tempo indicado na mesma tabela, observa-se que aproximadamente $90 \%$ das produções de GPPS e de HIPS ocorreram no sentido de abastecer o mercado interno.

Tabela 2: Produção e vendas declaradas expressas em toneladas de GPPS e HIPS no Brasil (ABIQUIM, 2010).

\begin{tabular}{lccc}
\hline Ano & Produção & Vendas Internas & Vendas Externas \\
\hline 2005 & 317.434 & 274.969 & 45.860 \\
\hline 2006 & 360.957 & 313.210 & 52.761 \\
\hline 2007 & 376.471 & 331.259 & 36.641 \\
\hline 2008 & 345.285 & 313.105 & 25.671 \\
\hline 2009 & 361.995 & 335.922 & 33.676 \\
\hline
\end{tabular}

Do total consumido, $35 \%$ foram destinados à fabricação de derivados poliméricos na forma de bens de consumo; outros $33,4 \%$ foram aproveitados no segmento de eletrodomésticos; um total de $18,1 \%$ atendeu ao mercado de embalagens alimentícias; frações menores - de 2,2\% e 1,0\% respectivamente - serviram aos segmentos de informática e construção civil; e os demais 10,3\% estiveram pulverizados por muitos mercados.

Vale ressaltar que apesar da subutilização das instalações fabris na produção de poliestireno, parte do material consumido e exportado pelo país foi importada, como mostra a Tabela 3.

Tabela 3: Importação e Exportação de GPPS e HIPS no Brasil (ABIQUIM, 2010).

\begin{tabular}{lcc}
\hline Ano & Importação [t/ano] & Exportação [ t/ano] \\
\hline 2005 & 18.347 & 46.353 \\
\hline 2006 & 16.347 & 55.762 \\
2007 & 16.156 & 40.169 \\
\hline 2008 & 18.209 & 26.475 \\
2009 & 15.980 & 34.480 \\
\hline
\end{tabular}

Dados da ABIQUIM (2011) apontam que as principais importações brasileiras de GPPS ocorrem a partir dos Estados Unidos e da Argentina, sendo realizadas principalmente para atender a compromissos comerciais específicos, ou absorver oscilação de demanda tanto interna como de exportação. 


\subsubsection{Poliestireno: rota tecnológica petroquímica}

A produção de poliestireno é um processo essencialmente petroquímico derivado da manufatura do monômero de estireno. Este último, por sua vez, tem na nafta sua matéria-prima essencial. De acordo com Antunes (2007), a tecnologia de processamento do monômero de estireno ocorre, fundamentalmente, por meio de cinco etapas: (i) extração de petróleo cru e gás natural; (ii) refino para produção de nafta; (iii) produção de petroquímicos básicos; (iv) produção de etilbenzeno; e, por fim, (v) obtenção do monômero de estireno. As produções tanto de GPPS como de HIPS se completam por meio de polimerização, que caracteriza a última etapa de transformação química do produto.

A Figura 1 abaixo representa a sequência de transformações necessárias para a produção de poliestireno na forma de um diagrama de blocos.

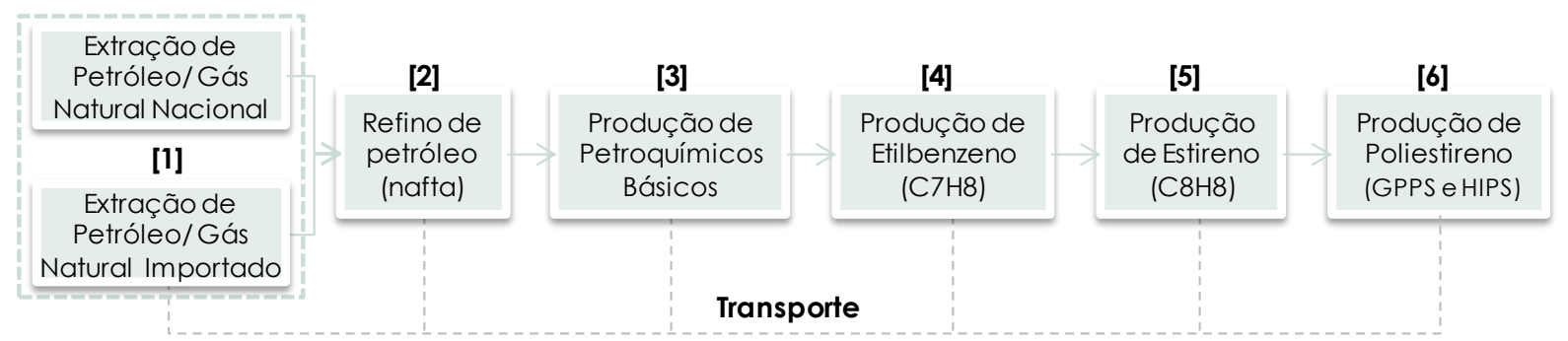

Figura 1: Sequência de operações relacionadas à produção de poliestireno a partir de ativos fósseis

A seguir são apresentados detalhes específicos sobre mercados, procedências e, sobretudo, tecnologias praticadas no país para cada qual destas transformações, tanto no tocante ao GPPS como para o HIPS. Tais informações ocorrem com nível de detalhe suficiente para que o leitor possa compreender as reflexões empreendidas na presente incursão de pesquisa.

\subsubsection{Extração de Petróleo e Gás Natural}

A manufatura de poliestireno inicia-se na fase de extração de petróleo e gás natural, a qual, para efeito deste estudo, compreende as atividades de bombeamento, prétratamento e transporte do petróleo cru e gás natural produzidos em território nacional e internacional. 


\subsection{Extração, pré-tratamento e bombeamento de Gás Natural}

De acordo com a Agência Nacional do Petróleo, Gás Natural e Biocombustíveis (ANP) entende-se por gás natural como todo hidrocarboneto que permaneça em estado gasoso nas condições atmosféricas normais, extraído diretamente de reservatórios petrolíferos ou gasíferos, incluindo gases úmidos, secos, residuais e gases raros (ANP, 2011).

Sob o viés geológico, o gás natural pode ser classificado em duas categorias: (i) não associado e (ii) associado. Na primeira (i), o gás é encontrado em reservatórios livre ou em presença de diminutas quantidades de óleo e água. Na segunda (ii), o gás é assim definido por estar dissolvido em petróleo ou sob a forma de capa de gás.

No cenário brasileiro, a produção de gás associado representou, nos últimos quatro anos, mais de $70 \%$ do total de gás natural extraído, conforme mostra a Tabela 4.

Tabela 4: Produção de gás natural associado e não associado 2008-2011 (ANP, 2012)

\begin{tabular}{ccccc}
\hline \multirow{2}{*}{ Ano } & \multicolumn{2}{c}{ Produção em milhões de $\mathbf{m}^{3}$} & \multicolumn{2}{c}{ Percentual de Contribuição } \\
& Gás associado & Gás Não Associado & Gás associado & Gás Não Associado \\
\hline $\mathbf{2 0 0 8}$ & 14.519 & 7.074 & $62,7 \%$ & $37,3 \%$ \\
$\mathbf{2 0 0 9}$ & 16.976 & 4.165 & $80,3 \%$ & $19,7 \%$ \\
$\mathbf{2 0 1 0}$ & 17.300 & 5.638 & $75,4 \%$ & $24,6 \%$ \\
$\mathbf{2 0 1 1}$ & 17.650 & 6.424 & $73,3 \%$ & $26,7 \%$ \\
\hline
\end{tabular}

A origem do gás natural e os processos naturais ao qual este é submetido influenciam na sua composição química. Santos et. al. (2002) ressaltam - por meio dos dados constantes na Tabela 5 - que a despeito desta condição, o gás natural é composto em especial por: metano; etano; propano; e pequenas concentrações de hidrocarbonetos de maior peso molecular. Além desses elementos, o gás natural apresenta baixas concentrações de impurezas como nitrogênio, dióxido de carbono, água e compostos de enxofre.

Tabela 5: Composição elementar do gás natural associado e não associado (SANTOS, et. al., 2002).

\begin{tabular}{lcc}
\hline \multirow{2}{*}{ Elementos } & \multicolumn{2}{c}{ Composição (\% em peso) } \\
& Associado & Não Associado \\
\hline Metano & 81,57 & 85,48 \\
\hline Etano & 9,17 & 8,26 \\
\hline Propano & 5,13 & 3,06 \\
\hline I-Butano & 0,94 & 0,47 \\
\hline
\end{tabular}




\begin{tabular}{lcc}
\hline \multirow{2}{*}{ Elementos } & \multicolumn{2}{c}{ Composição (\% em peso) } \\
\cline { 2 - 3 } & Associado & Não Associado \\
\hline N-Butano & 1,45 & 0,85 \\
\hline I-Pentano & 0,26 & 0,20 \\
\hline N-Pentano & 0,30 & 0,24 \\
\hline Hexano & 0,15 & 0,21 \\
\hline Heptano e Superiores & 0,12 & 0,06 \\
\hline Nitrogênio & 0,52 & 0,53 \\
\hline Dióxido de Carbono & 0,39 & 0,64 \\
\hline
\end{tabular}

Ao ser extraído do reservatório por sistema de bombeamento, o gás natural passa por vasos separadores, cuja função é, além de retirar a água, também separar o gás dos hidrocarbonetos em estado líquido. O processo de purificação é complementado na etapa de depuração, na qual partículas líquidas e sólidas de hidrocarbonetos são removidas (TALAVERA, 2002).

Ainda na plataforma de extração, o gás natural é direcionado à unidade de adoçamento ou dessulfurização, caso esteja contaminado por compostos de enxofre. Nesta etapa, sistemas de absorção química ou física são adotados para garantir ao final do processo um gás seco desacidificado, segundo as premissas da ANP, Regulamento Técnico n. ${ }^{\circ}$ 001/98 (SANTOS et. al., 2002).

Após este tratamento primário, o gás é enviado por meio de gasodutos até as Unidades de Processamento de Gás Natural (UPGN), onde é desidratado e fracionado (MELO, 2005). Tanto nas plataformas de extração quanto nas UPGNs, parte do gás natural é utilizada para alimentar o sistema de geração de energia das unidades produtoras (SANTOS et. al., 2002).

\subsection{Extração, pré-tratamento e bombeamento de Petróleo}

O petróleo, também denominado óleo cru, é uma mistura líquida constituída principalmente por hidrocarbonetos e pequenas quantidades de compostos orgânicos como: enxofre, oxigênio, nitrogênio e metais.

Suas propriedades físicas estão relacionadas à razão $(\mathrm{H} / \mathrm{C})$ dos compostos de hidrocarbonetos, de tal modo que quanto menor esta razão, maior é sua massa específica e seu ponto de ebulição (FAHIN, AL-SAHHAF E ELKILANI, 2012). 
Apesar da composição do óleo cru ser distinta em cada local de origem, os teores de carbono, hidrogênio e dos demais componentes apresentam pequenas flutuações, como é possível identificar na Tabela 6.

Tabela 6: Composição elementar de óleos crus (FAHIN, AL-SAHHAF E ELKILANI, 2012).

\begin{tabular}{lc}
\hline \multicolumn{1}{c}{ Elemento } & Composição (\% em peso) \\
\hline Carbono & $83,0-87,0$ \\
\hline Hidrogênio & $10,0-14,0$ \\
\hline Enxofre & $0,05-6,0$ \\
Nitrogênio & $0,1-0,2$ \\
Oxigênio & $0,05-2,0$ \\
\hline Níquel & $<120$ ppm \\
\hline
\end{tabular}

Segundo a Agência Nacional de Petróleo (ANP, 2011), exatos 80,2\% do petróleo processado no país são de origem nacional. Dos complementares 19,8\% obtidos de importação, destacaram-se para o período 2009-2010 as procedências de: Nigéria (56,5\%), Arábia Saudita (19,1\%), Iraque (7,9\%), Argélia (4,8\%) e Angola (3,8\%). Juntos estes países responderam por cerca de $90 \%$ do óleo cru importado pelo Brasil no período de referência.

Quanto à extração, levantamentos realizados pela ANP para o ano 2010 apontam que $91,2 \%$ do petróleo nacional foram extraídos de atividades realizadas no mar (offshore), e apenas 8,8\% originaram-se de ações em terra (onshore). Os valores absolutos correspondentes e essa produções aparecem expressos por estado da federação na Tabela 7. Em valores totalizados, os mesmos percentuais acima destacados compreendem a 684 milhões de barris offshore e 66 milhões de barris onshore, respectivamente.

Tabela 7: Produção de petróleo, por localização (terra e mar) e Unidades da Federação - 2010 (ANP, 2011).

\begin{tabular}{lcc}
\hline Unidades da Federação & \multicolumn{2}{c}{ Produção de Petróleo - 2010 [mil barris] } \\
\hline Amazonas & Terra & Mar \\
\hline Ceará & 13030 & 0 \\
\hline Rio Grande do Norte & 674 & 2261 \\
\hline Alagoas & 17868 & 2914 \\
\hline Sergipe & 2029 & 85 \\
\hline Bahia & 12020 & 3063 \\
\hline Espírito Santo & 15551 & 343 \\
\hline
\end{tabular}




\begin{tabular}{lcc}
\hline \multirow{2}{*}{ Unidades da Federação } & \multicolumn{2}{c}{ Produção de Petróleo - 2010 [mil barris] } \\
\cline { 2 - 3 } & Terra & Mar \\
\hline Rio de Janeiro & 0 & 594804 \\
São Paulo & 0 & 5278 \\
\hline Total & 65.973 & 683.980 \\
\hline
\end{tabular}

O petróleo bruto extraído offshore é, então, processado ainda nas plataformas para a remoção preliminar de água salobra, gás, sais, sedimentos e parte de compostos de enxofre comuns nos campos brasileiros. Esta atividade visa dois importantes objetivos: [1] reduzir a possibilidade de corrosão e acúmulo de sedimentos nos dutos, além de riscos relacionados ao transporte de gás; e, [2] diminuir o volume de material a ser bombeado e encaminhado para as refinarias, otimizando assim o dimensionamento das tubulações.

Almeida (2006) expõe que este tratamento primário aplicado ao petróleo bruto ainda na plataforma é composto por etapas de decantação e desidratação. A decantação é o mesmo processo físico simples anteriormente mencionado na extração de gás natural, no qual petróleo, água e gás são separados por diferença de densidade. Já a desidratação é um processo químico que faz uso de desemulsificantes para a redução da água no petróleo, visando que a corrente final deste tratamento tenha apenas $1 \%$ de água e sais.

O efluente líquido produzido nesta etapa é encaminhado para tratamento, sendo lançado a corpos hídricos se em conformidade com os padrões estabelecidos pela Resolução CONAMA.

Já o petróleo previamente tratado, é encaminhado aos parques petroquímicos por meio de uma rede de oleodutos que interligam terminais terrestres e aquaviários às áreas de tancagem. O petróleo bruto importado é, por sua vez, desembarcado nos terminas oceânicos e aquaviários e segue, também, via oleodutos para as refinarias. 


\subsubsection{Refino de Petróleo}

O refino corresponde ao processo de transformação do petróleo cru para a produção de derivados energéticos ${ }^{2}$ e não energéticos ${ }^{3}$. No ano de 2010 , foram processados cerca de 105 milhões $\mathrm{m}^{3}$ de petróleo cru nas dezesseis refinarias em funcionamento no território brasileiro (ANP, 2011).

No que tange à fabricação do poliestireno, é nesta altura do processo que se obtém a nafta, que será posteriormente processada para a obtenção de eteno e benzeno. Segundo estatísticas da ANP, no ano de 2010 a nafta teve grande expressividade dentro do grupo de derivados não energéticos. Esta prevalência pode ser ilustrada pelos dados constantes da Tabela 8 que se segue.

Tabela 8: Produção de derivados de petróleo $\mathrm{m}^{3}$ - ano base 2010 (ANP, 2011).

\begin{tabular}{llll}
\hline Derivados & Produção [m $\left.{ }^{3}\right]$ & Contribuição (\%) & Acumulado (\%) \\
\hline Óleo Diesel & 41.429 .263 & $37,61 \%$ & $37,61 \%$ \\
\hline Gasolina & 23.157 .357 & $21,02 \%$ & $58,64 \%$ \\
\hline Óleo Combustível & 13.883 .271 & $12,60 \%$ & $71,24 \%$ \\
\hline Gás Liquefeito de Petróleo (GLP) & 9.452 .748 & $8,58 \%$ & $79,82 \%$ \\
\hline Nafta & 7.311 .298 & $6,64 \%$ & $86,46 \%$ \\
\hline Querosene & 4.690 .009 & $4,26 \%$ & $90,72 \%$ \\
\hline Coque não energético & 3.056 .971 & $2,78 \%$ & $93,49 \%$ \\
\hline Outros não energéticos & 2.931 .870 & $2,66 \%$ & $96,15 \%$ \\
\hline Asfalto & 2.767 .281 & $2,51 \%$ & $98,67 \%$ \\
\hline Lubrificante & 603.154 & $0,55 \%$ & $99,21 \%$ \\
\hline Solvente & 508.705 & $0,46 \%$ & $99,68 \%$ \\
\hline Outros Energéticos & 262.275 & $0,24 \%$ & $99,91 \%$ \\
\hline Parafina & 94.196 & $0,09 \%$ & $100,00 \%$ \\
\hline Total & 110.148 .398 & $100 \%$ & --- \\
\hline
\end{tabular}

Cabe ressaltar que apenas onze das dezesseis refinarias produziram nafta no período apresentado na Tabela 8 supramencionada.

\footnotetext{
2 Segundo a ANP (2011), classificam-se como derivados energéticos, aqueles utilizados como combustível, isto é, cuja finalidade seja liberar energia, luz ou ambos. Enquadram-se nessa definição: gasolina A, gasolina de aviação, GLP, óleo combustível, óleo diesel, querosene iluminante, querosene de aviação e coque.

3 Derivados não energéticos de petróleo são aqueles que, embora possuam significativo teor energético, não são utilizados para este fim. Fazem parte dessa classificação: graxas, lubrificantes, parafinas, asfaltos, solventes, coque, nafta, extrato aromático, gasóleo de vácuo, óleo leve de reciclo, resíduo atmosférico, diluentes, n-parafinas, outros óleos de petróleo, minerais betuminosos, entre outros produtos de menor importância (ANP, 2011).
} 
Destacam-se, nesse âmbito, a Refinaria Landulpho Alves (RLAM), Refinaria de Duque de Caxias (Reduc), Refinaria Henrique Lage (REVAP) e Refinaria Alberto Pasqualini (REFAP), que juntas somaram 73,3\% da produção de nafta em 2010.

A respeito da tecnologia de processo, o sistema de refino de petróleo apresenta diversas variações nos âmbitos mundial e nacional, seja pelas características do material processado ou pela gama de produtos que se pretende alcançar no beneficiamento (TAVARES, 2005).

Além disso, o avanço das regulamentações ambientais demandaram melhorias contínuas por parte das indústrias petroquímicas, incentivando o avanço tecnológico e elevando a complexidade das plantas de refino (ALMEIDA, 2006).

Fahin, Al-Sahhaf e Elkilani (2012) explicam que, atualmente, as refinarias modernas compõem processos de separação física e conversão química que em conjunto viabilizam a obtenção dos derivados de petróleo. No cenário brasileiro, esta condição tecnológica é compatível com as instalações das refinarias em operação, mesmo para o caso do processamento de petróleos leves e médios.

De acordo com Gomes (2011), as refinarias brasileiras podem ser enquadradas em três configurações. A primeira, e mais simples delas, é constituída apenas por uma unidade de destilação atmosférica e de processos de tratamentos físicos ou químicos para processamento de petróleos leves, geralmente importados, com enfoque na produção de combustíveis e solventes. O segundo grupo de refinarias, refere-se aquelas instaladas no país nas décadas de 1960 e 1970, e que possuem unidades de destilação atmosférica, destilação a vácuo e de craqueamento catalítico, no intuito de maximizar a produção de combustíveis veiculares.

A terceira e última configuração engloba um conjunto complexo de sistemas, a fim de proporcionar maior produtividade de derivados leves e flexibilidade no processamento dos petróleos nacionais pesados. Por este motivo, esse modelo de refinaria é adotado em grande parte dos parques existentes, em especial naqueles de propriedade da Petrobrás. De acordo com a ANP (2012), tais refinarias são compostas pelas seguintes etapas: (i) sistema de aquecimento e dessalinização do petróleo cru; (ii) destilação atmosférica; (iii) destilação a vácuo; (iv) craqueamento catalítico, (v) coqueamento; e, (vi) hidrotratamento. A Figura 2 apresenta de forma esquemática 0 processo de refino e seus produtos, conforme as etapas previamente mencionadas. 


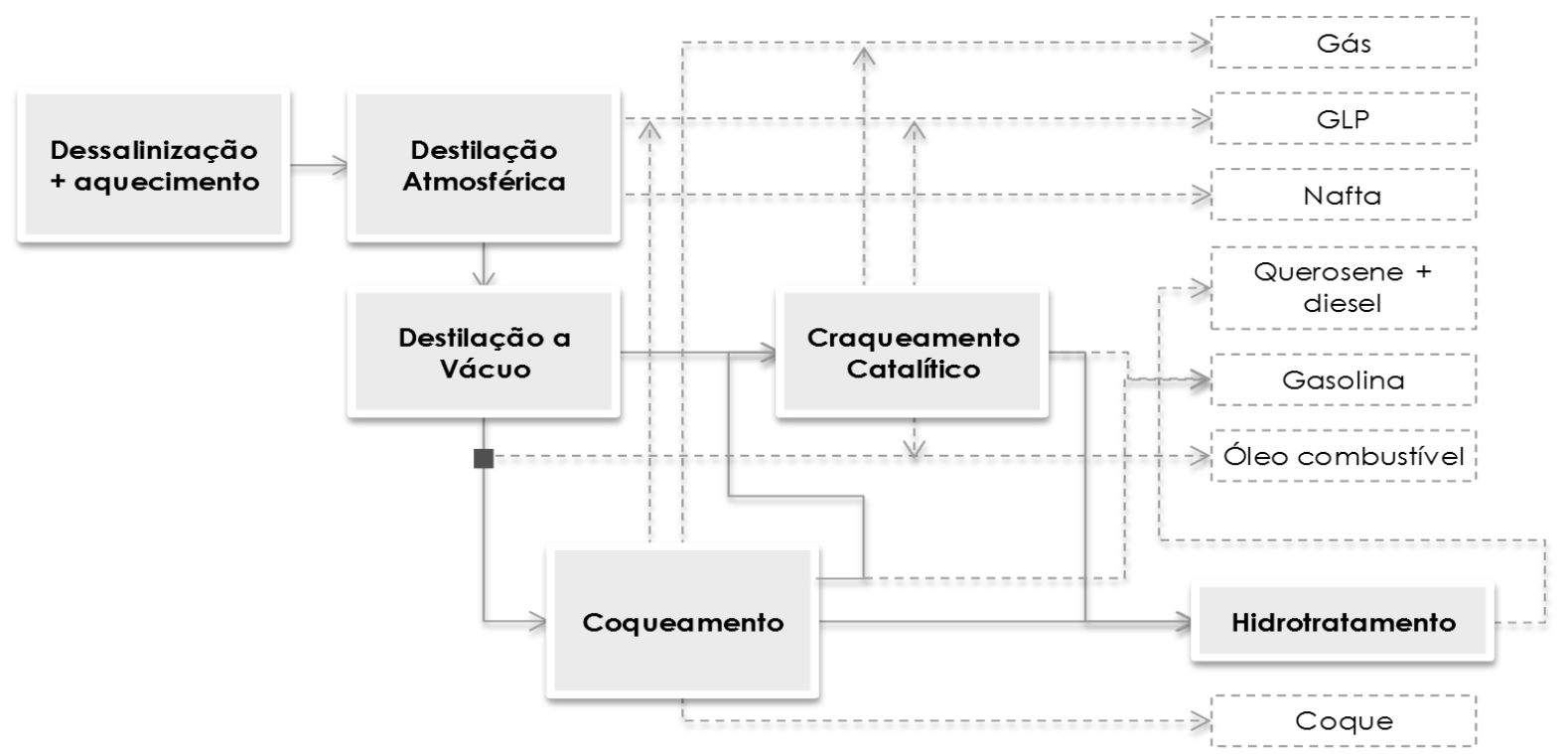

Figura 2: Esquema do processo de Refino de Petróleo (adaptado de ANP, 2011).

Em qualquer das modalidades descritas, o processo de refino se inicia com as operações de dessalinização e aquecimento do petróleo bruto, também denominado de óleo cru, recebido das unidades de extração e de importação.

Mariano (2001) explica que o sistema de dessalinização das refinarias visa remover sais, água, partículas sólidas suspensas e metais do petróleo cru bruto que ainda não foram plenamente retirados nos tratamentos dados na plataforma.

Deste modo são removidas substâncias corrosivas que possam danificar a unidade de destilação e os catalisadores utilizados nas etapas posteriores a esta unidade, aumentando assim a vida útil desses equipamentos.

O processo de dessalinização, então, compreende uma mistura de petróleo cru aquecido em cerca de $3 \%$ a $10 \%$ de seu volume em água. Com o uso de desemulsificadores, esta água carreia os sais, gerando efluentes na forma de borra oleosa e água salgada residual, sempre a altas temperaturas, que seguem para a estação de tratamento antes de serem descartados no ambiente (ALMEIDA, 2006). O petróleo dessalinizado é aquecido até $400^{\circ} \mathrm{C}$ para o estabelecimento das condições ideais de fracionamento, sendo, posteriormente, encaminhado para a torre de destilação atmosférica.

Pereira (2010) descreve a destilação atmosférica como primeiro processo físico para fracionamento do petróleo em produtos. Nesta etapa, mantidas as condições de temperatura da corrente de entrada, são geradas duas correntes principais: a primeira delas formada por frações vaporizadas de componentes mais leves - GLP e nafta 
leve; e a segunda, constituída por frações líquidas que darão origem ao óleo diesel, nafta pesada e querosene.

Tecnicamente, parte das frações obtidas nesta etapa não possuem as especificações técnicas necessárias para a comercialização direta, sendo encaminhadas para outros processos de tratamento ou fracionamento, como indicado pela Figura 2 acima destacada.

As frações não vaporizadas na coluna e de alta massa molecular, denominadas genericamente de resíduo atmosférico, são retiradas sob a forma de asfaltos ou "cru reduzido" e serão reaquecidas e reprocessadas por destiladores a vácuo (Petrobras, 2002).

A função da unidade de destilação a vácuo é fracionar o resíduo atmosférico em diesel e gasóleos leve e pesado, maximizando a produção de derivados petroquímicos com maior potencial econômico. Neste processo, o cru reduzido é submetido a pressões sub-atmosféricas para o rebaixamento da temperatura de ebulição. Os vapores resultantes dessa unidade de destilação são constituídos, sobretudo, por vapor d'água, hidrocarbonetos leves não condensáveis (butanos, etanos, pentanos, entre outros) e gás sulfídrico, enquanto o resíduo emanado do mesmo processo compõese de hidrocarbonetos de elevada cadeia molecular. Tal resíduo é segmentado na unidade de coqueamento (PEREIRA, 2010).

Nessa etapa de conversão química, o material é aquecido em fornos a uma temperatura aproximada de $500^{\circ} \mathrm{C}$ para a obtenção de gases combustíveis, nafta, diesel, gasóleo de coque e coque de petróleo (GOMES, 2011). Para que haja o retardamento da formação de coque, vapor de água é injetado antes do aquecimento, a fim de aumentar a turbulência e velocidade da carga nos fornos (ANTUNES, 2007). Ao sair dos fornos de funcionamento contínuo, a carga é encaminhada para tambores, onde permanece por um longo período de tempo para depósito do coque e resfriamento. A quantidade de tambores é dimensionada de tal sorte que o processo ocorre de forma contínua. Nesta unidade, a remoção e resfriamento dos vapores de hidrocarbonetos e coque resultam na emissão de efluentes líquidos, que mais uma vez são encaminhados à estação de tratamento da refinaria. Além desses, emissões atmosféricas relacionadas ao sistema de aquecimento, vapores remanescentes e eventuais emissões fugitivas de hidrocarbonetos são gerados durante a operação (MARIANO, 2001). 
Tanto os gasóleos pesados da destilação a vácuo quanto aqueles do coqueamento são encaminhados para a unidade de craqueamento catalítico, cujo objetivo é converter o material em produtos mais leves, como gasolina e GLP.

Atualmente, a tecnologia mais frequente nas refinarias brasileiras é a de craqueamento em leito fluidizado (FCC). Neste processo injeta-se a carga fresca na base do equipamento, no qual o catalisador aquecido se encontra. $O$ calor do catalisador vaporiza o material de entrada, iniciando as reações de craqueamento catalítico. A temperatura de reação de quebra das moléculas nesta unidade é em torno de $700^{\circ} \mathrm{C}$ (Petrobras, 2002).

De acordo com Pereira (2010), "o catalisador gasto e os produtos voláteis do craqueamento separam-se no vaso do reator e no retificador". A deposição de material nos catalisadores produz coque, que é queimado para a regeneração do catalisador. O calor produzido é aproveitado para aquecer a carga de entrada do processo; no entanto, há significativa emissão de poluentes atmosféricos na mesma unidade. Outras emissões vinculadas à geração de calor, bem como emissões fugitivas de hidrocarbonetos compõem o restante dos poluentes gerados no FCC (GOMES, 2011). Os produtos voláteis do craqueamento são conduzidos para a fracionadora e separados em função do ponto de ebulição (BAPTISTA, PINHO e GILBERT, 2006). Por fim, os produtos gerados nas unidades de destilação e coqueamento são encaminhados para o sistema de hidrotratamento, em que serão removidas impurezas como enxofre, nitrogênio e haletos. Para tanto, são utilizados catalisadores e hidrogênio a alta pressão e temperatura, com os quais se atingi as condições de reação entre a carga e o gás (PEREIRA, 2010).

Além das correntes de produtos tratados, gases sulfídrico e combustível deixam o processo, sendo posteriormente encaminhados à unidade de tratamento de gases ácidos e a unidade de recuperação de enxofre (MARIANO, 2001).

\subsubsection{Produção de Intermediários}

A produção de insumos intermediários para a manufatura de HIPS e GPPS é composta pelos petroquímicos básicos eteno, benzeno e butadieno, sendo este último posteriormente processado à polibutadieno. 
Schutte (2004) explica que a rota tecnológica para a obtenção desses compostos ocorre a partir da transformação de nafta e/ou de gás natural. Entretanto, para o cenário brasileiro, a utilização de nafta é majoritária.

Nesse sentido, será descrito a seguir as características dos processos de transformação de nafta para cada um dos insumos intermediários requeridos na indústria de poliestireno.

\subsection{Produção de eteno e benzeno}

A nafta produzida por meio do refino de petróleo é, usualmente, transportada por tubovias para as unidades petroquímicas de segunda geração. De acordo com a ABIQUIM (2011), três empresas são responsáveis pela produção de benzeno em território nacional, enquanto que duas dessas mesmas unidades também produzem eteno. A Tabela 9 apresenta a capacidade instalada dessas indústrias para ambos os insumos.

Tabela 9: Capacidade instalada de benzeno e eteno no Brasil (ABIQUIM, 2011).

\begin{tabular}{lccc}
\hline \multirow{2}{*}{ Empresas } & Localização & \multicolumn{2}{c}{ Capacidade instalada [t/ano] -2010} \\
\hline Braskem & BA/RS & Benzeno & Eteno \\
\hline Petrobrás & SP & 714.000 & 2.532 .000 \\
\hline Quattor & RJ/SP & 30.076 & - \\
\hline Total & & 230.000 & 1.240 .000 \\
\hline
\end{tabular}

Segundo Netzer (2005), corroborado por Pereira (2010) são duas as principais rotas tecnológicas para produção de eteno e benzeno: (i) craqueamento térmico a vapor e (ii) reforma catalítica.

Conforme apresenta Antunes (2007), o craqueamento térmico a vapor constitui-se na maior fonte de petroquímicos básicos, com rendimentos em massa de eteno próximos a $30 \%$. Tal produtividade faz com que o processo seja amplamente utilizado no Brasil para a produção deste intermediário. No caso em questão, a corrente de nafta e gás natural é craqueada em cadeias moleculares menores por fornos de pirólise que operam em condições específicas de processo - entre $815^{\circ} \mathrm{C}$ e $900^{\circ} \mathrm{C}$, e 2 atm de pressão -, gerando eteno. 
O gás craqueado é, então, comprimido à 35atm para a remoção de ácidos que são encaminhados à unidade de tratamento de gases. A separação e fracionamento dos produtos gerados por este processo - casos de eteno, etano, propeno, propano, butadieno e aromáticos - acontece em unidades de refrigeração que reduzem a temperatura do gás para $95-130^{\circ} \mathrm{C}$.

A porção gasosa formada por hidrogênio, metano e monóxido de carbono é purificara para a remoção do hidrogênio, sendo os demais componentes queimados para a geração de energia na planta (Antunes, 2007).

As correntes de etano e propano são recicladas para o forno de pirólise no intuito de transformá-las em eteno e propeno. Analogamente, acetileno e propino são hidrogenados a eteno e propeno, respectivamente. Sobre o efluente do processo, este é resfriado em trocadores de calor e reintroduzido no processo.

Ainda no âmbito do processamento de eteno, Gomes (2011) ressalta que a falta de disponibilidade de matéria-prima associada à busca por processos produtivos mais limpos e avanços tecnológicos têm propiciado a conversão de fontes renováveis, como cana-de-açúcar, em produtos petroquímicos. Para tanto, são utilizadas rotas bioquímicas, termoquímicas e alcoolquímicas que permitem a produção de eteno a partir de etanol. Em termos quantitativos, a produção e eteno via cana-de-açúcar representou em 2011 uma produção anual de 200 mil toneladas por ano. Entretanto, esta produção tende a aumentar com a instalação de novas plantas com capacidade conjunta de 710 mil toneladas ano, conforme evidencia a relação de projetos de investimento apresentada no relatório da ABIQUIM (2010). Esta rota tecnológica de produção de eteno será descrita mais adiante no capítulo de revisão de literatura.

Quanto à produção de benzeno, Netzer (2005) explica que a reforma catalítica corresponde a 55\% da produção mundial do petroquímico. No processo, reatores são posicionados em série para um melhor desempenho da reação de desidrogenação de naftênicos em aromáticos. De acordo com informações da Petrobrás (2002), a unidade de reformação catalítica é composta pelas seções de pré-tratamento, transformação e estabilização respectivamente. Na primeira das seções, a carga de nafta é misturada a um gás rico em hidrogênio na presença de catalisadores, sendo posteriormente aquecida em trocadores de calor a temperaturas entre $260^{\circ} \mathrm{C}$ e $340^{\circ} \mathrm{C}$. O intuito do processo é remover impurezas em forma de gases sulfurados, nitrogenados e oxigenados, além de eventuais metais que ficam retidos na superfície do catalisador. 
As emanações atmosféricas do processo são a seguir encaminhadas à unidade de tratamento de gases, enquanto o catalisador junto ao metal é destinado como resíduo sólido perigoso.

Na etapa de transformação, a corrente de nafta pré-tratada recebe nova carga de gás rico em hidrogênio, sendo encaminhada para reatores para ser aquecida entre $470^{\circ} \mathrm{C}$ e $530^{\circ} \mathrm{C}$, a fim de desencadear reações de aromatização. O reformado obtido pela reação é fracionado na torre de estabilização, na qual são geradas correntes de benzeno, Isoparafínicos, produtos leves (GLP e gás combustível), hidrogênio e coque (ANTUNES, 2007).

\subsection{Produção de Polibutadieno}

O polibutadieno é um elastômero com elevada propriedade elástica, alta resiliência, boa resistência à abrasão e bom comportamento de amortecimento. Sua manufatura é derivada do processo de polimerização do butadieno que, ao reagir, propicia a formação de ligações duplas em sua estrutura molecular, as quais resultam em isomerismos e ampla variedade polimérica (COSTA, 2009).

De acordo com a ABIQUIM (2010), duas indústrias são responsáveis pela produção de butadieno no território nacional. A Braskem, localizada nos estados da Bahia e Rio Grande do Sul, possuía em 2009 o equivalente a 75\% da capacidade instalada produtiva brasileira (286 mil toneladas/ano), enquanto que a Quattor inteirava os demais $25 \%$ da capacidade instalada com 95 mil toneladas /ano.

Do montante de butadieno produzido, cerca de $40 \%$ foi destinado à fabricação de borrachas, dentre elas o elastômero de polibutadieno, e $60 \%$ foi encaminhado à indústria de intermediários químicos.

Ainda segunda a ABIQUIM (2010), a Lanxess Elastômeros é a única indústria listada como produtora de polibutadieno no Brasil. Conforme apresentado pela Lanxess Elastômeros (2013), as unidades fabricantes de borracha de polibutadieno estão localizadas nos estados de Rio de Janeiro (Duque de Caxias), Pernambuco (Cabo de Santo Agostinho) e Rio Grande do Sul (Triunfo).

Sob o viés tecnológico, o processo de obtenção de butadieno mais recorrente no mundo é a extração destilativa, na qual butadieno é subproduto da linha de produção de eteno e propeno (BACKES, 2011). 
Conforme descrito anteriormente deste mesmo estudo, uma unidade de separação e fracionamento ao término do sistema de craqueamento térmico a vapor é responsável por separar eteno, etano, propeno, propano, butadieno e aromáticos em diferentes correntes.

Backes (2011) explica que este processo é composto por quatro etapas, sendo duas de destilações extrativas, uma seção de fracionamento e uma seção de purificação de solvente. Nessa rota, solventes, tal como dimetilformamida, são aplicados para alterar as características de volatilidade dos componentes, separando-os em correntes distintas, a fim de obter 1,3-butadieno com elevado grau de pureza.

O produto do processo é resfriado e armazenado sobre pressão para permanecer em estado líquido, sendo transferido via tubovias às unidades de produção de polibutadieno.

Os sistemas catalíticos utilizados na polimerização de butadieno são influenciados significativamente conforme o tipo de catalisador e iniciador empregado no processo (NUNES, COUTINHO e MELLO,2005).

Grassi e Dal Pizzol (2008) colocam que a polimerização que apresenta os melhores resultados de eficiência faz uso da tecnologia de catálise de coordenação. Neste processo, complexos com metais de transição, como cobalto (PB-Co) e neodímio (PB$\mathrm{Nd}$ ) são empregados para gerar os chamados polibutadienos de alto-cis, com o conteúdo do isômero 1,4-cis entre $96 \%$ e $98 \%$.

\subsubsection{Produção de Etilbenzeno}

A obtenção do monômero de estireno passa pela produção de etilbenzeno, um intermediário químico do processo, de aparência incolor e líquida. Oliveria et al (2005) explicam que as principais rotas de produção de etilbenzeno são: alquilação de benzeno com eteno; alquilação de tolueno com metanol; transalquilação de dietilbenzeno ou trietilbenzeno com benzeno; e, transalquilação de tolueno. Entretanto, a alquilação de benzeno com eteno é, atualmente, a rota mais utilizada no país para produção de etilbenzeno em escala econômica. Neste processo, ambas as correntes de eteno e benzeno são pré-aquecidas antes de entrar nos reatores.

A alquilação em fase líquida de eteno grau polímero com benzeno refinado ocorre em temperaturas brandas entre $85-95^{\circ} \mathrm{C}$ e a pressão atmosférica. Condições de processo 
tão acessíveis são proporcionadas pela presença de catalisadores, como zeólitas ou cloreto de alumínio.

Durante o processo, benzeno em excesso é introduzido no reator para garantir a conversão completa de eteno por meio de reações exotérmicas. Parte do benzeno excedente sofre reações adicionais de alquilação, produzindo compostos denominados de polietilbenzenos (dietilbenzeno e trietilbenzeno). Assim, a corrente resultante dos reatores - composta por benzeno não reagido, etilbenzeno produto e compostos polialquilados - é posteriormente fracionada em torre de destilação. Desta etapa, o etilbenzeno é encaminhado para a manufatura de monômero de estireno, enquanto benzeno é reciclado para o processo de origem e os compostos polialquilados são convertidos em etilbenzeno por reatores de transalquilação (ANTUNES, 2007).

\subsubsection{Produção de Estireno}

A obtenção do monômero de estireno pode ocorrer por diferentes rotas tecnológicas, tal como descreve Holtz (2008), dentre as quais citam-se: desidrogenação do etilbenzeno em presença de vapor; desidrogenação oxidativa de etilbenzeno; alquilação e desproporcionamento de metanol; oxidação de propeno; e, degradação de poliestireno reciclado. Das rotas tecnológicas mencionadas, diversos autores confirmam que a desidrogenação catalítica do etilbenzeno em presença de vapor d'água é a de maior utilização em escala mundial (BURRI et. al., 2008; BAGHALLA, 2007 apud HOLTZ, 2008).

O processo compreende reação endotérmica em sistemas adiabáticos colocados em série, aos quais se interpõe um reaquecimento da carga de etilbenzeno em presença de vapor.

Devido a característica endotérmica da reação, as temperaturas dos reatores adiabáticos flutuam durante o processo, resultando em taxas de conversão baixas, que raramente excedem $50 \%$. Isso ocorre em função de reações secundárias não desejáveis, a partir das quais serão produzidos respectivamente: benzeno, tolueno, rejeitos de hidrocarbonetos e coque (LEITE, OLIVEIRA, RANGEL, 2004).

A regulação da temperatura a níveis aproximadamente constates - entre $540^{\circ} \mathrm{C}$ e $650^{\circ} \mathrm{C}$ - ocorre por contato com vapor superaquecido e leitos catalíticos compostos 
por óxidos inorgânicos, em particular óxidos de ferro, potássio e cério, em cujos sítios ativos o etilbenzeno não apenas circula, mas também reage. A razão entre o vapor d'água e o etilbenzeno no processo pode variar entre 4:1 e 20: 1. O excesso de vapor visa aumentar a vida útil e estabilidade do catalisador (HOLTZ, 2008).

Além do estireno - produto principal da reação - integram também a corrente de saída pequenas quantidades de etilbenzeno não convertido, bem como benzeno e tolueno resultantes de reações secundárias. Por questões econômicas, o etilbenzeno é purificado e reciclado no reator de desidrogenação. Já o benzeno, retorna a unidade produtora de etilbenzeno, enquanto que o tolueno é destinado à venda (HOSSAIN et. al., 2012). Os catalisadores, quando inutilizados no processo, retornam aos fornecedores para a reciclagem.

Por fim, o estireno é resfriado e recebe a injeção de produtos químicos com ação antioxidante, denominados inibidores, a fim de evitar a polimerização do material nas condições normais de temperatura e pressão.

\subsubsection{Produção de Poliestireno}

A produção do poliestireno cristal (GPPS) é realizada comercialmente em reatores contínuos agitados (CSTR) colocados em série, conforme mostra a Figura 3. Nesses equipamentos, as reações de polimerização do monômero de estireno são manipuladas por iniciadores, temperatura de reação e tempo de residência.

De acordo com Martins (2009) a reação ocorre na presença de peróxido orgânico como iniciador e requer o uso de solvente para controle da reação. O solvente introduzido no processo - usualmente etilbenzeno - representa entre $2 \%$ e $30 \%$ da carga total de entrada. Este é, em geral, empregado para controlar a viscosidade do fluido no reator e a relação de massa molar média pela taxa de produção, de modo a garantir uma melhor eficiência de conversão (ALMEIDA, WADA \& SECCHI, 2008).

Em termos termodinâmicos, as melhores conversões são obtidas com perfis isotérmicos. No entanto, o fato da conversão do monômero de estireno ser exotérmica, predispõe a instalação de sistemas de remoção de energia nos reatores. Para tanto, camisas de óleos térmicos envolvem os reatores para que os mesmos operem adiabaticamente. A temperatura da reação varia normalmente de $120^{\circ} \mathrm{C}$ a 
$180^{\circ} \mathrm{C}$, porém, o uso de iniciadores de processo leva a redução da temperatura para valores próximos de $90^{\circ} \mathrm{C}$, mantendo-se a efetividade do processo (ALMEIDA, 2004).

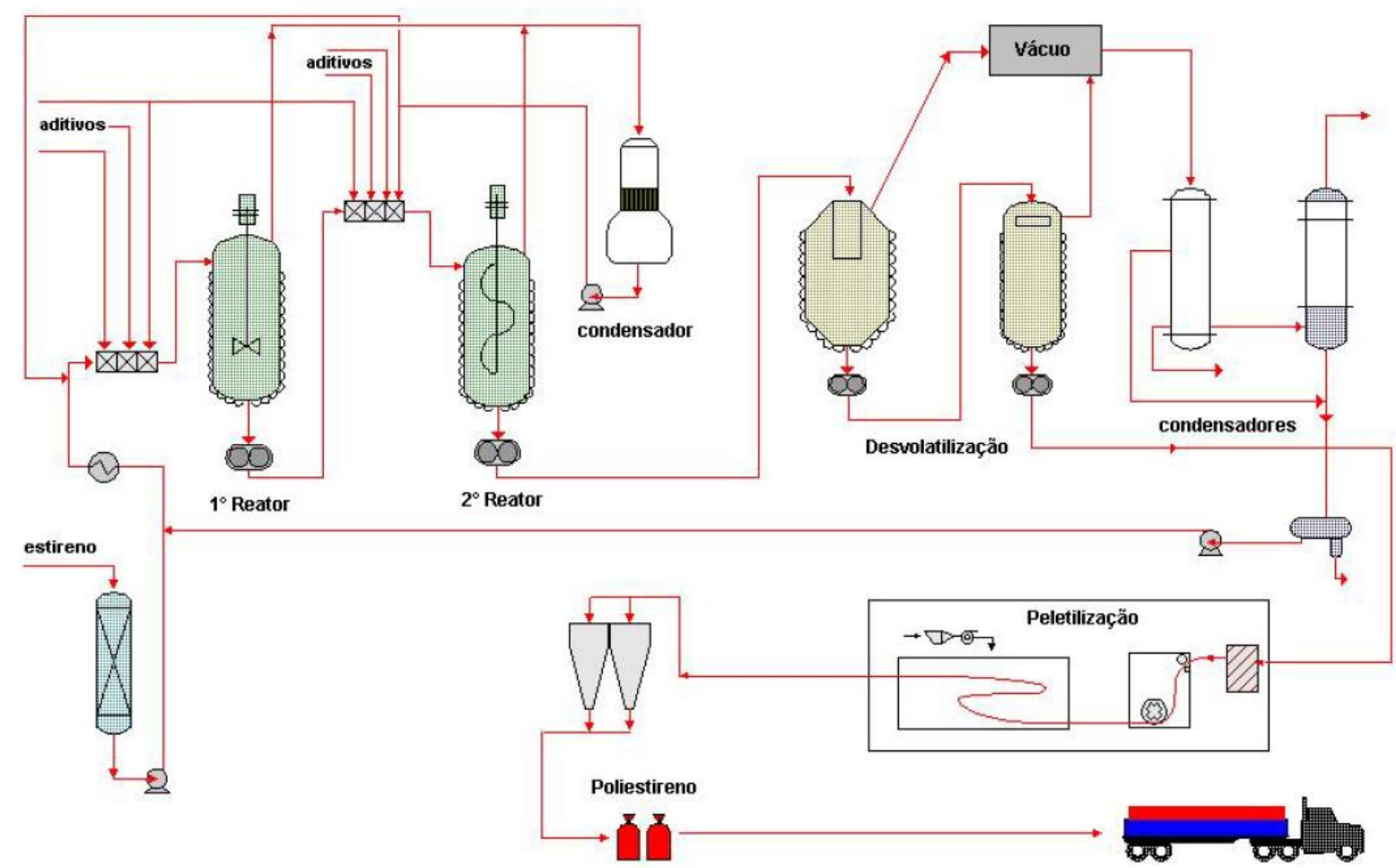

Figura 3: Fluxograma simplificado de uma unidade de produção de poliestireno (Almeida, 2004).

Odian (2004) aponta que a conversão média do monômero de estireno no primeiro reator é da ordem de 30\%; já o produto final obtido no segundo reator apresenta aproximadamente $70 \%$ de poliestireno convertido, misturado a estireno não reagido e solvente.

Após a polimerização, a solução produzida pelo último reator é encaminhada para um evaporador flash, no qual ocorre a remoção do monômero não convertido e de resquícios de solvente. Esta etapa, denominada desvolatização, eleva a temperatura do polímero fundido entre $220^{\circ} \mathrm{C}$ a $260^{\circ} \mathrm{C}$, para que este seja ajustado a sua característica de uso final (ALMEIDA, 2004). O fluído, então, praticamente livre de voláteis é bombeado e encaminhado para a granulação, onde a massa polimérica é transformada em pellets.

O monômero de estireno não reagido, bem como o solvente evaporado na etapa de desvolatização, são reintroduzidos no início do processo (MARTINS, 2009).

A produção de poliestireno de alto impacto (HIPS) segue as mesmas etapas processuais apresentadas para a obtenção de GPPS, com uma diferença relacionada 
à adição de elastômeros de polibutadieno ao monômero de estireno. Neste sentido, a borracha de poliestireno é solubilizada pelo monômero de estireno na etapa de polimerização (ARAUJO, 2006).

A inserção deste elastômero é responsável pela alteração das propriedades mecânicas do poliestireno, elevando a resistência ao impacto e resistência química sob tensão. Segundo Forte e Dal Pizzol (2001), o teor de borracha em resinas de HIPS representa cerca de $10 \%$ em peso e entre $10 \%$ a $40 \%$ em volume.

\subsubsection{Poliestireno: rota tecnológica via fonte renovável}

A crescente preocupação da sociedade moderna com a emissão de Gases Efeito Estufa e, portanto, com a necessidade de adoção de mecanismos de produção mais limpos nas indústrias, tem estimulado a busca de fontes alternativas ao petróleo para produção de insumos e intermediários químicos (TAVARES, 2005 e GOMES, 2011). Aliada a esta questão e talvez, tão representativa quanto ela, está o aprimoramento da legislação ambiental, bem como a indisponibilidade de matéria-prima a preços competitivos para a indústria petroquímica devido à importação de recursos. Destacase para esta última problemática, a manufatura de produtos derivados de nafta, visto que atualmente o volume de produção deste insumo no território nacional é insuficiente para atender a demanda brasileira, conforme evidencia a Tabela 10, o que afeta diretamente a produção de eteno $-\mathrm{C}_{2} \mathrm{H}_{4}-\mathrm{e}$ dos demais derivados resultantes de seu processamento (PEREIRA et al, 2007).

Diante deste cenário, o processamento de recursos renováveis em substituição aos derivados petroquímicos tornou-se, nas últimas décadas, uma alternativa importante para a produção de combustíveis no Brasil e, mais recentemente, para a manufatura de alguns intermediários petroquímicos utilizados na manufatura de plásticos (SCHUCHARDT e RIBEIRO, 2001).

Tabela 10: Produção, Importação e Exportação de Nafta no Brasil (ANP, 2012)

\begin{tabular}{lccc}
\hline Ano & Produção Nacional $\left[\mathrm{m}^{3}\right]$ & Importação $\left[\mathrm{m}^{3}\right]$ & Exportação $\left[\mathrm{m}^{3}\right]$ \\
\hline 2006 & 8.663 .731 & 4.278 .160 & 31.943 \\
\hline 2007 & 9.244 .639 & 4.176 .748 & 26.458 \\
2008 & 8.142 .804 & 3.593 .727 & 103.386 \\
2009 & 8.412 .608 & 4.119 .592 & 50.399 \\
2010 & 7.355 .761 & 6.714 .020 & 0 \\
\hline
\end{tabular}


Em consonância com este movimento da indústria e sob o enfoque do processo de fabricação do poliestireno, a rota tecnológica via fonte renovável difere daquela de origem petroquímica pelo uso de biomassa para a obtenção de eteno a partir de álcool etílico hidratado.

No Brasil, a produção de etanol ocorre, principalmente, a partir de cana-de-açúcar. Segundo Grisoli (2011), esta matéria-prima apresenta uma das melhores taxas de conversão fotossintéticas para a produção de biocombustíveis de primeira geração. No biênio 2010 - 2011, a produção total de etanol no país ultrapassou a marca dos 28,4 milhões de litros, garantindo o primeiro lugar na lista de produtores mundiais desta commoditie (CONAB, 2011).

Neste contexto, o refino de petróleo para a produção de eteno no processo de manufatura do poliestireno é substituído pelo processo de cultivo de cana-de-açúcar, seguido pelas etapas de produção de etanol e obtenção de eteno por desidratação. Este sequenciamento aparece ilustrado a Figura 4.

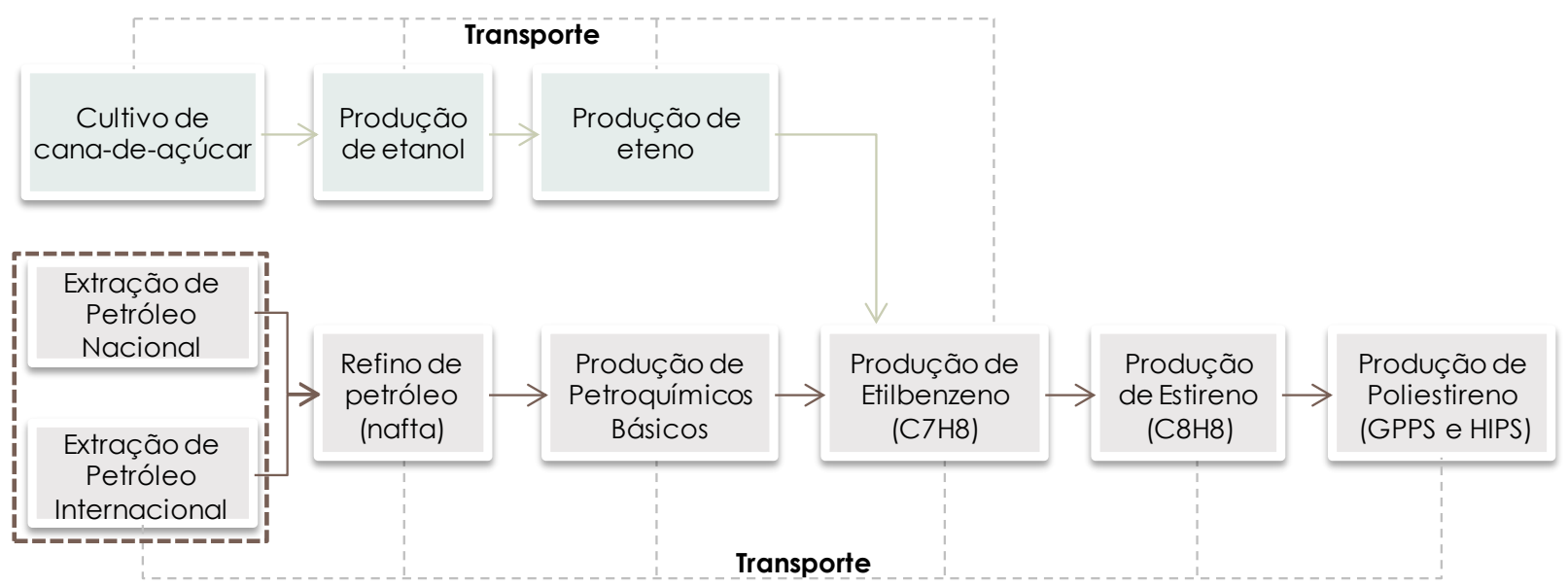

Figura 4: Fluxograma da produção de poliestireno a partir de ativos fósseis e renovável

A seguir serão descritos os processos de cultivo de cana-de-açúcar, produção de etanol e obtenção de eteno a partir de álcool etílico hidratado, na forma como estes são praticados no país atualmente. 


\subsubsection{Cultivo de Cana-de-açúcar}

A cana-de-açúcar é uma gramínea, monocotiledônea, cuja formação vegetal é composta por raízes, colmos, pontas e folhas (SEJIMO, 2011), conforme mostra a Figura 5. De acordo com esta estrutura, é na região dos colmos que se concentra a sacarose que, por fermentação, origina o etanol.

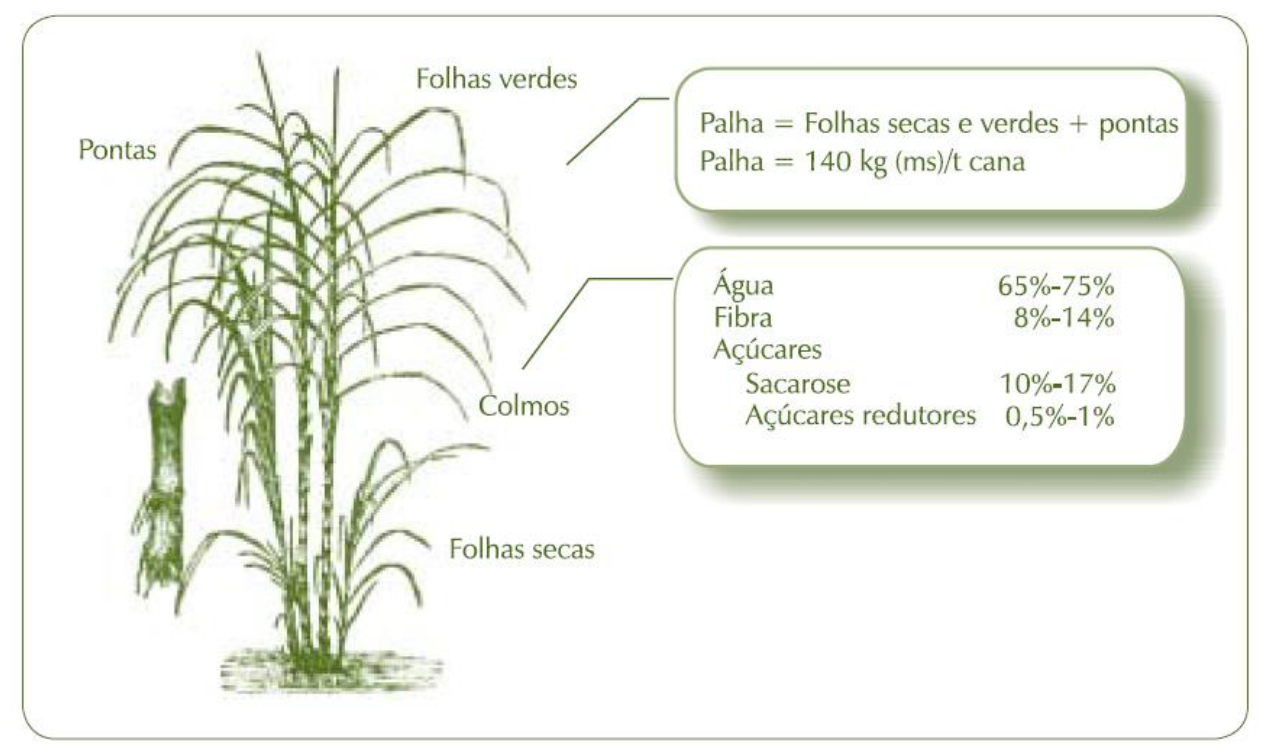

Figura 5: Estrutura típica da biomassa da cana-de-açúcar (BNDES, 2008).

Segundo Seabra (2008), o ciclo completo da cana-de-açúcar varia conforme as condições climáticas e as práticas culturais. No Brasil, este ciclo é de aproximadamente seis anos, dentro do qual ocorrem cinco cortes. O primeiro dos cortes acontece entre 12 e 18 meses após o plantio, enquanto as demais colheitas são realizadas ao longo dos quatro anos consecutivos. Baseado em informações fornecidas pela CONAB (2011), o cultivo de cana-de-açúcar no território nacional está centralizado nas regiões centro-sul e nordeste do país, ambas destacadas dentro das circunferências que constam no mapa da Figura 6. 


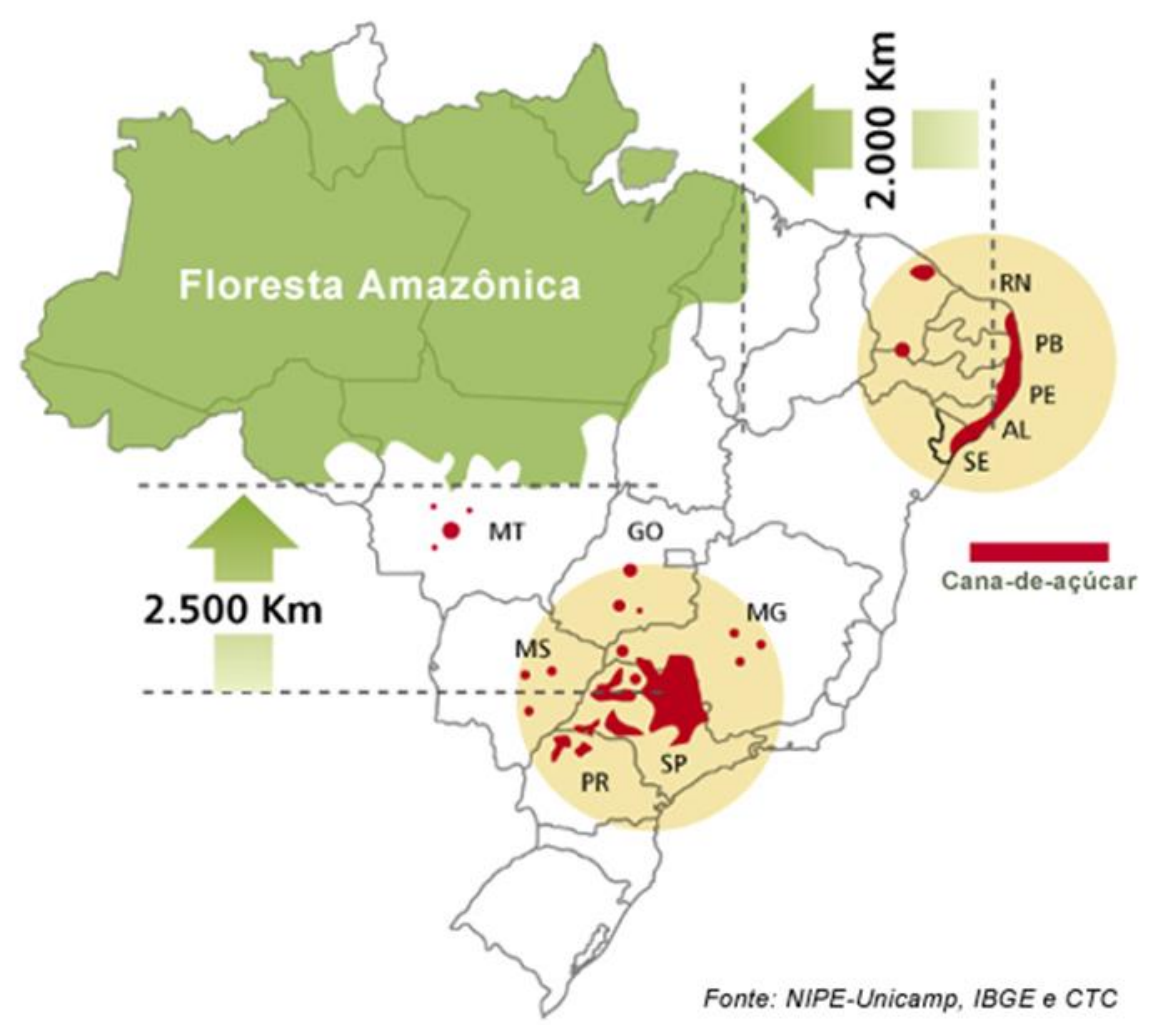

Figura 6: Mapa de produção de cana-de-açúcar no Brasil (ÚNICA, 2012).

Dentre os estados brasileiros, São Paulo é enquadrado como o maior produtor de cana-de-açúcar por possuir 53,6\% das terras cultivadas para este fim. Este mesmo estado responde pelas maiores produtividades agrícolas de cana do país, atingindo de 87 a 98 t/ha ao longo das colheitas, com picos de até 140 t/ha, conseguidos em geral no segundo ou terceiro ano de cultivo (CONAB, 2011).

No Brasil, a produção de cana compreende as seguintes operações: preparação do solo, semeadura, tratos culturais e colheita. Quanto a preparação do solo, cerca de 20 a 30 centímetros de terra são revolvidos e preparados para o recebimento das mudas. Nesta etapa são consumidos macro nutrientes primários - amônia, ureia, superfosfato simples e triplo, ou fosfatos de mono e diamônio, além de cloreto de potássio - e corretivos de acidez e defensivos agrícolas - triazina, diuron, ametrina, diquat e 2,4-D -, essenciais para propiciar o crescimento adequado do cultivo.

A quantidade de fertilizantes aplicada nesta operação varia de acordo com as características de trato do solo, especialmente no que tange ao uso de vinhaça e torta de filtro, rejeitos do processo de obtenção de etanol e açúcar, que propiciam a redução do uso de adubos químicos e a correção dos teores de matéria orgânica dos solos (CGEE, 2009). 
As mudas a serem plantadas também recebem tratamento fungicida e inseticida prévio para controle de pragas e doenças, sendo posteriormente cobertas com 5 a 10 centímetros de terra.

Dados apresentados pela Companhia Nacional de Abastecimento (CONAB, 2011), confirmam que o consumo médio brasileiro de mudas por hectare é de 15 toneladas, podendo ultrapassar 20 toneladas quando o plantio é mecanizado. Neste âmbito é válido ressaltar que o consumo de óleo diesel é inerente à preparação de solo pelo uso de máquinas agrícolas, visto que $55 \%$ da cana-de-açúcar produzida no Brasil advêm de mecanização (CONAB, 2013).

Novaes (2010) explica que o último estágio do cultivo, a colheita, ocorre de três formas no território nacional: [1] sistema manual com queima prévia do canavial; [2] colheita mecanizada simples com queima da palha e [3] colheita mecanizada de cana picada sem queima do canavial.

Para as situações em que ocorre a queima, o fogo ateado visa remover as folhas secas e verdes que não são aproveitadas no processo de transformação da cana, sendo os colmos posteriormente cortados e armazenados inteiros na colhedora.

Neste processo, há grande emissão de poluentes atmosféricos compostos por dióxido de carbono, monóxido de carbono, metano, fuligem, dentre outros gases que, além de degradarem o ambiente e prejudicam a saúde dos trabalhadores. Por estes motivos, a colheita com queima prévia da palha está sendo gradativamente banida e substituída por sistemas mecânicos sem queima (AYARZA, 2007).

$\mathrm{Na}$ colheita mecanizada, os colmos, as pontas e as folhas são cortados e separados, sendo os colmos armazenados no interior das colhedoras e encaminhados para picagem e despalhamento ainda em campo (SALAZAR, 2012).

Após o corte, a cana é transportada rapidamente para a usina, de modo a evitar a perda de sacarose. Segundo o Centro de Gestão de Estudos Estratégicos (2009), as áreas de cultivo no Centro-Sul usualmente encontram-se localizadas próximas às usinas, de modo que a distância média percorrida entre o campo e a destilaria nesta região é de aproximadamente $25 \mathrm{~km}$.

Este transporte é realizado por caminhões até às plantas sucroalcooleiras, onde a cana é estocada ou diretamente encaminhada para o processo de moagem (GRISOLI, 2011). Os principais tipos de transporte da cana, suas capacidades e utilizações estão apresentados na Tabela 11. 
Tabela 11: Tipos de Transporte de cana - dados de 2005 (CTC, 2006 apud SEABRA, 2008).

\begin{tabular}{lcc}
\hline Tipo & Capacidade (t) & Contribuição (\%) \\
\hline Caminhão & 15 & 2 \\
Romeu e Julieta & 28 & 22 \\
\hline Treminhão/Rodotrem & $45 / 58$ & 76 \\
\hline
\end{tabular}

\subsubsection{Produção de etanol hidratado a partir de cana-de-açúcar}

O processamento da cana-de-açúcar pode ocorre em dois modelos distintos de unidades fabris: usinas com destilarias anexas, as quais produzem etanol e açúcar; e, destilarias autônomas, nas quais há a produção exclusiva de etanol. No Brasil, as plantas produtoras de etanol somaram 355 unidades no ano de 2007, das quais 288 usinas estão localizadas na Região Centro-Sul do país (CGEE, 2009).

Destaca-se, ainda, entre os estados produtores, São Paulo, onde neste mesmo ano se concentravam 172 plantas produtoras de etanol.

Tal como expõe o relatório desenvolvido pela CGEE (2009), a configuração tecnológica das usinas de etanol brasileira apresenta poucas variações, seja no tipo e qualidade dos equipamentos ou nos controles operacionais. Segundo Dias, (2011), as operações comumente empregadas nas destilarias para produção de etanol hidratado a partir do caldo da cana-de-açúcar são: recepção, limpeza e preparo da cana-de-açúcar; extração de açúcares; tratamento do caldo; concentração do caldo; fermentação; destilação e geração de energia. A Figura 7 ilustra as operações anteriormente mencionadas.

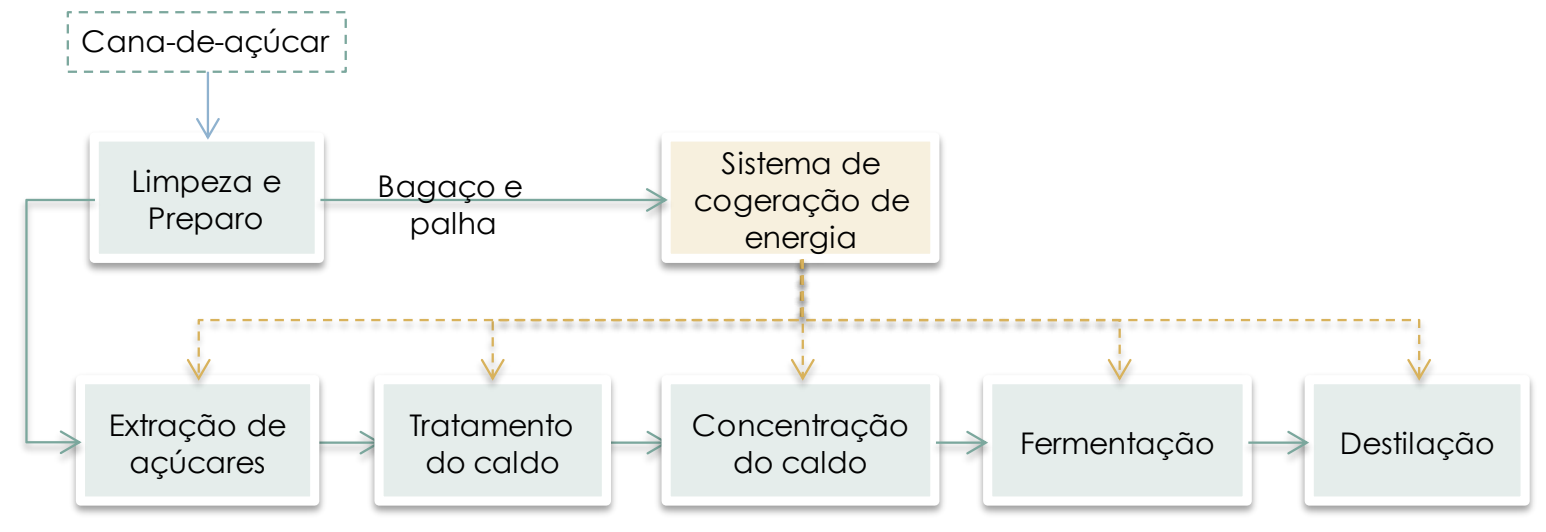

Figura 7: Fluxograma do processo de produção de etanol hidratado a partir de cana-de-açúcar 
O processo de limpeza e preparo da cana-de-açúcar visa remover impurezas minerais e vegetais. Nesta etapa, a cana é descarregada em esteiras e conduzida para o processo de lavagem que utilizada água em circuito fechado. (SEJIMO, 2011).

Dias (2011) descreve que a eficiência de remoção de terra do processo é de aproximadamente $90 \%$, enquanto que o consumo médio de água é da ordem de $2,2 \mathrm{~m}^{3}$ / tonelada de cana. O efluente gerado é, então, encaminhado para tratamento e reaproveitado no mesmo processo.

Após a lavagem, a cana é picada e esmagada para a uniformização do material a ser enviado para a etapa de extração de açúcares.

Segundo Salazar (2012), a tecnologia mais utilizada nas usinas sucroalcooleiras para a extração de açúcares é a moagem por moendas, na qual rolos montados em conjuntos com quatro a sete ternos sucessivos removem, por pressão, o caldo com sacarose. O bagaço resultante da extração é utilizado na planta para a geração de energia térmica e elétrica. Já o caldo segue para o processo de peneiramento, no qual são retirados os bagacilhos ${ }^{4}$.

O resíduo do peneiramento é reintroduzido nas moendas, enquanto que o caldo segue para a produção de etanol (DIAS, 2011).

O tratamento químico do caldo ocorre por meio de calagem, aquecimento e decantação para a remoção de impurezas na forma de compostos solúveis e insolúveis. A primeira etapa do tratamento é o aquecimento do caldo a temperaturas de cerca de $100^{\circ} \mathrm{C}$, cuja função é eliminar bactérias que possam propiciar a perda de açúcares em condições favoráveis de baixas temperaturas.

O caldo quente é direcionado para a calagem, onde leite de cal é adicionado para: [1] neutralizar a acidez do caldo; [2] reagir com ácidos orgânicos; [3] precipitar os colóides presentes no caldo; e, [4] flocular partículas em suspensão. Vale ressaltar que as características de pureza após a calagem são semelhantes àquelas do caldo introduzido ao processo. Entretanto, esta etapa é essencial para a eficiência da decantação, no qual floculantes são misturados ao caldo para a aglomeração e sedimentação dos flocos de impurezas (SEJIMO, 2011). O lodo do processo de decantação é encaminhado para a filtragem, a fim de recuperar parte do açúcar arrastado.

\footnotetext{
${ }^{4}$ Bagacilhos são as fibras arrastadas junto com o caldo no processo de extração de açúcares.
} 
O material filtrado é reciclado para a etapa de calagem e o resíduo sólido - torta de filtro - é utilizado como fertilizante no canavial (SUGAWARA, 2012).

Uma vez tratado, o caldo é evaporado para ajustar sua concentração de açúcares e, eventualmente, misturado com o melaço residual da linha de produção de açúcar. $O$ produto desta etapa, denominado mosto, prossegue para a fermentação.

A fermentação alcoólica é um processo biológico que converte açúcares em etanol e dióxido de carbono. Para que esta reação ocorra são adicionadas leveduras do gênero Saccharomyces cerevisiae ou Schizosaccharomyces pombe, em condições controladas de temperatura $\left(30-34^{\circ} \mathrm{C}\right)$ e $\mathrm{pH}(4,5-5,5)$, que permitem que o mosto seja fermentado dando origem ao vinho com concentração de 7\% a 10\% de álcool em massa. O tempo de reação do processo varia entre 8 a 12 horas, e o rendimento de conversão de açúcar é superior a 90\% (BERECHE, 2011).

Por se tratar de uma reação exotérmica, o controle de temperatura das dornas de fermentação é realizado de maneira indireta com água em de trocadores de calor (SALAZAR, 2012). Dado que o processo de fermentação é realizado sob condições anaeróbicas, há liberação de grandes quantidades de gás carbônico $\left(\mathrm{CO}_{2}\right)$ durante a metabolização da glicose (BNDES, 2008).

$\mathrm{Na}$ destilação, o vinho procedente da fermentação é concentrado para a obtenção de etanol na forma hidratada, com aproximadamente $96^{\circ} \mathrm{GL}$. O processo ocorre em duas etapas. Na primeira etapa, o vinho é aquecido e submetido à destilação, na qual são obtidas três correntes: a flegma, composta por vapores hidroalcóolicos de $45-50^{\circ} \mathrm{GL}$; o etanol de segunda, rico em voláteis; e a vinhaça, classificada como o resíduo da destilaria, com baixo teor de álcool. Na segunda etapa, a flegma segue para a coluna de retificação, gerando álcool hidratado (SALAZAR, 2012). As colunas de destilação e retificação operam à pressão ambiente, com vapor a baixa pressão (entre 1,5 e 2,5 bar). De forma análoga as condensadoras, usadas para resfriar os vapores alcoólicos das colunas, utilizam água.

\subsubsection{Produção de eteno via etanol}

\subsection{Histórico da produção de eteno a partir de etanol}

A produção de eteno a partir de etanol foi descoberta há dois séculos, por meio da técnica de desidratação catalítica. 
No Brasil, a tecnologia de transformação do etanol em eteno foi desenvolvida pelo Centro de Pesquisas e Desenvolvimento da Petrobrás - CENPES - em 1960. Entre 1960 e 1970, pequenas plantas que convertiam etanol em eteno foram inauguradas pela Petrobrás e pela Salgema. O interesse pelo desenvolvimento dessas unidades cresceu, sobremaneira, em 1970, em decorrência da crise do petróleo, resultando no desenvolvimento de patentes brasileiras na década de 1980 (MARQUES, 2010).

Por outro lado, a crescente disponibilidade de eteno por pirólise de hidrocarbonetos não só desestimulou o crescimento de novas plantas de desidratação catalítica de etanol como propiciou o fechamento de todas as unidades existentes em território nacional até o ano de 1992 (LIMA, 2010).

Mais recentemente, a melhoria da produtividade do etanol, a redução de seu custo de produção e a preocupação em reduzir os impactos ambientais associados à produção de bens derivados de petróleo, estimularam as indústrias do setor petroquímico a retomarem a tecnologia de produção de eteno a partir de etanol.

Como consequência desta ação, a Braskem inaugurou em 2010 uma unidade de produção de eteno derivado de etanol de cana-de-açúcar com capacidade produtiva de 200.000 t/ano.

Além desta, outras unidades de manufatura de eteno via cana-de-açúcar estão listadas nos projetos de investimento de 2010 a 2015 da ABIQUIM (2010). De acordo com o relatório da Associação Brasileira da Indústria Química (2010), a Solvay Indupa e a Dow Brasil irão instalar em futuro próximo, unidades com capacidade produtiva de 360 mil e 350 mil t/ano de eteno renovável, respectivamente. Essas unidades estarão localizadas nos estados de São Paulo e Minas Gerais, ou seja, próximas aos polos produtivos de cana-de-açúcar e etanol.

\subsection{Produção de eteno a partir de etanol}

A desidratação de etanol é apresentada na Equação 2 (MARQUES, 2010).

$$
\mathrm{C}_{2} \mathrm{H}_{5} \mathrm{OH} \leftrightarrow \mathrm{C}_{2} \mathrm{H}_{4}+\mathrm{H}_{2} \mathrm{O}
$$

Trata-se de uma transformação endotérmica de entalpia da ordem de $39 \mathrm{kcal} / \mathrm{kg}$. 
Segundo Cameron, et. al. (2012), o processo de conversão de etanol não ocorre em condições normais de temperatura e pressão, uma que vez que estas são desfavoráveis ao equilíbrio da reação para a formação de eteno.

Nesse sentido, para que o processo de desidratação catalítica de etanol atinja taxas de conversão satisfatórias, são empregadas tecnologias de produção baseadas em reatores de leito fixo. Tais reatores podem operar de modo isotérmico ou adiabático para a manutenção da temperatura de reação.

Convencionalmente, os processos de desidratação que trabalham em condições isotérmicas utilizam fluídos aquecidos para fornecer calor ao sistema, a partir do uso de tubos instalados no entorno do reator. Deste modo, o aquecimento ocorre de maneira indireta, mantendo a temperatura de operação entre $330^{\circ} \mathrm{C}$ e $380^{\circ} \mathrm{C}$. Segundo Morschbacker (2009), nesse modelo de manufatura, as taxas de conversão de etanol são de $98 \%$ a $99 \%$, com seletividade molar de eteno da ordem de $95 \%$ a $99 \%$.

Por outro lado, Barrocas, Silva e Assis (1980) ressaltam que o emprego de reatores isotérmicos pode resultar em falhas no sistema de transferência de calor, além de demonstrar desvantagens técnicas e econômicas, especialmente no que se refere à dificuldade de manutenção da temperatura e elevado consumo de combustível.

Assumindo uma eficiência de conversão de 95\%, Marques (2010) coloca que o consumo de etanol no processo varia de 1,7-2,2kg etanol/kg eteno.

No que tange a tecnologia de desidratação a partir de reatores adiabáticos de leito fixo, duas patentes desenvolvidas pela Petrobrás (US Patent 4.232.179 e US Patent 4.396.789) indicam que as operações que compõem o processo são: pressurização e aquecimento do etanol; desidratação de etanol; separação de vapores; destilação; adsorção; e destilação criogênica. A Figura 8 ilustra a configuração de uma planta de desidratação catalítica em condições adiabáticas.

$\mathrm{Na}$ etapa de aquecimento e pressurização, o etanol hidratado utilizado no processo é aquecido por meio de trocadores de calor até alcançar temperaturas próximas a $300^{\circ} \mathrm{C}$, e pressurizado para atingir uma pressão de aproximadamente $40 \mathrm{~atm}$.

A corrente de etanol aquecido é introduzida na etapa desidratação. Esta, por sua vez, é composta tipicamente por três reatores antecedidos por fornos de aquecimento que elevam a temperatura do fluxo de entrada dos reatores para a condição ideal de reação, superior a $360^{\circ} \mathrm{C}$ (BARROCAS e LACERDA, 2006). 


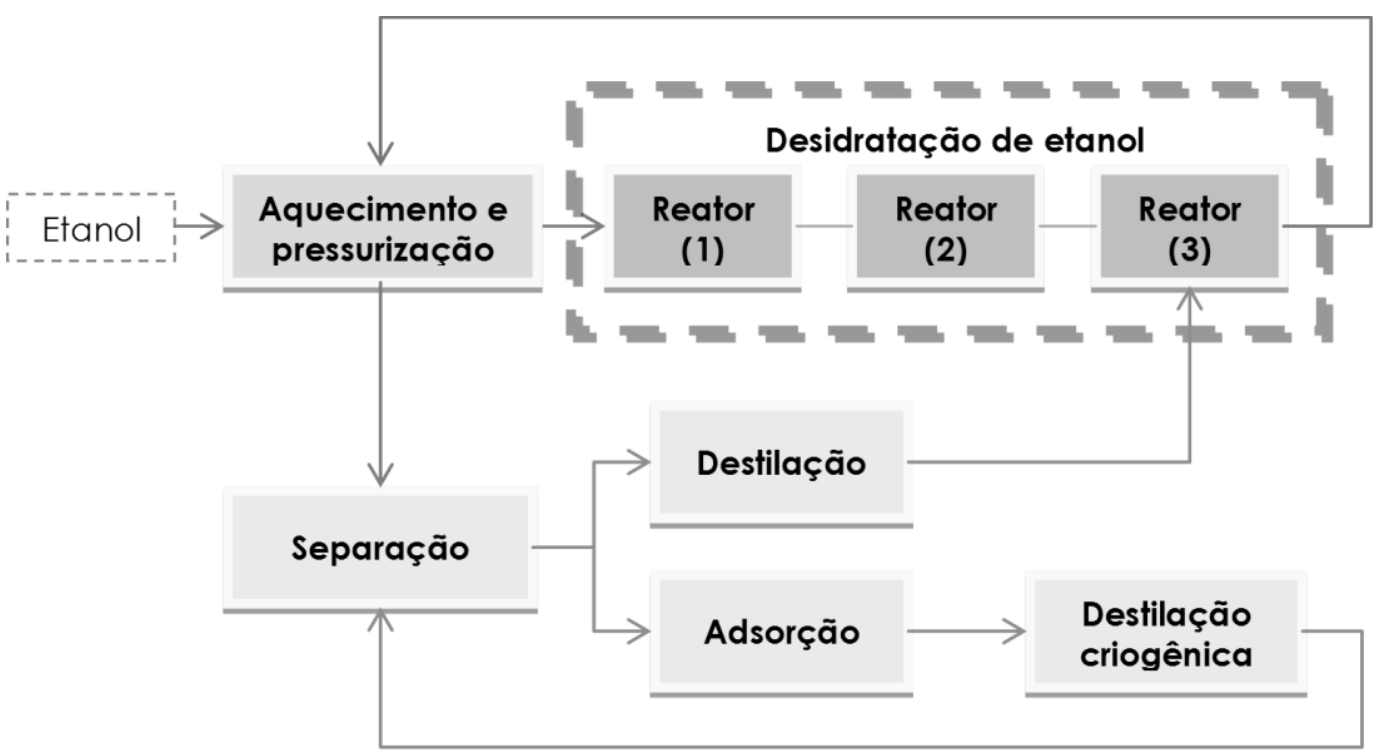

Figura 8: Fluxograma do processo de produção de eteno a partir de etanol

Os reatores são dispostos em série e funcionam em fluxo contínuo. Segundo Lima (2010), o tipo de catalisador empregado nos reatores tem forte influência na seletividade, conversão, temperatura e pressão de operação. Contudo, os reatores de maior recorrência nas unidades de desidratação catalítica são aqueles constituídos por alumina pura e sílica.

Durante o processo de conversão, reações secundárias que produzem éter etílico, acetaldeído, metano, ácido acético e etano acontecem em paralelo. Água e hidrogênio também são gerados em decorrência dessas mesmas reações secundárias, como evidenciam as Equações de 3 a 7 (CAMERON et. al., 2012).

$$
\begin{aligned}
& 2 \mathrm{C}_{2} \mathrm{H}_{5} \mathrm{OH} \leftrightarrow\left(\mathrm{C}_{2} \mathrm{H}_{5}\right)_{2} \mathrm{O}+\mathrm{H}_{2} \mathrm{O} \\
& \mathrm{C}_{2} \mathrm{H}_{5} \mathrm{OH} \leftrightarrow \mathrm{CH}_{3} \mathrm{COH}+\mathrm{H}_{2} \\
& \mathrm{C}_{2} \mathrm{H}_{5} \mathrm{OH}+\mathrm{H}_{2} \leftrightarrow 2 \mathrm{CH}_{4}+\mathrm{H}_{2} \mathrm{O} \\
& \mathrm{C}_{2} \mathrm{H}_{5} \mathrm{OH}+\mathrm{H}_{2} \mathrm{O} \leftrightarrow \mathrm{CH}_{3} \mathrm{COOH}+2 \mathrm{H}_{2} \\
& \mathrm{C}_{2} \mathrm{H}_{5} \mathrm{OH}+\mathrm{H}_{2} \leftrightarrow \mathrm{C}_{2} \mathrm{H}_{6}+\mathrm{H}_{2} \mathrm{O}
\end{aligned}
$$

A conversão de etanol em eteno no último reator varia de 97 a $99 \%$ quando a corrente de entrada dos reatores é mantida em temperaturas entre 400 a $500^{\circ} \mathrm{C}$. 
Enquanto que temperatura mais elevadas não oferecem benefícios em termos de eficiência de conversão, valores abaixo de $360^{\circ} \mathrm{C}$ estimulam o desenvolvimento das reações secundárias antes escritas (BARROCAS e LACERDA, 2006).

O produto da reação é resfriado no trocador de calor e encaminhado para a etapa de separação de vapores. Nesta, uma coluna de destilação flash é utilizada para remover a maior parte da água, gerando duas correntes: uma em fase líquida, rica em água; e outra em fase gasosa, composta por eteno, etanol não reagido e demais subprodutos do processo.

A corrente líquida é, então, encaminhada para a etapa de destilação, em que condições específicas de temperatura e pressão possibilitam a formação de novas correntes. A primeira delas, em fase líquida, é essencialmente composta por água e encaminhada para o sistema de tratamento da unidade industrial.

Já a segunda corrente é composta por resquícios de etanol que permaneceram do processo de separação, sendo posteriormente introduzida no terceiro reator de desidratação catalítica, para conversão do material em eteno (CAMERON et. al., 2012).

$\mathrm{Na}$ adsorção, a corrente gasosa da etapa de separação passa por uma coluna preenchida por partículas de zeólitas. O objetivo desta etapa é garantir a ausência de água e etanol na corrente de saída (CAMERON et. al., 2012).

Tanto o etanol quanto a água são adsorvidos pelas partículas de zeólitas, resultando na geração de resíduos sólidos. A corrente de eteno purificado é ainda separada de frações mais leves durante a destilação criogênica, a fim de se obter um produto, gasoso, com pureza superior a 99\% (CHEN, 2007). A corrente líquida composta por produtos das reações secundárias também é destinada à estação de tratamento de efluentes da planta.

Vale salientar que outras rotas tecnológicas estão sendo desenvolvidas no Brasil, com o intuito de unificar o processo de obtenção de eteno via insumos petroquímico e renovável. Nesse contexto, a Petrobrás, em meados de 2010, patenteou mecanismo de transformação de etanol por craqueamento catalítico. No processo em questão, etanol e hidrocarbonetos com ponto de ebulição entre $380^{\circ} \mathrm{C} \mathrm{e} 600^{\circ} \mathrm{C}$ são introduzidos em zonas diferentes do reator em presença de catalisadores. De acordo com Pinho et. al. (2008) a alimentação do reator é de aproximadamente $20 \%$ em massa de etanol e $80 \%$ em massa de gasóleo. 
A primeira zona do reator é denominada zona de desidratação de etanol; já a segunda seção corresponde à área em que o gasóleo é craqueado. As condições de processo da primeira zona do reator são: tempo de contato de 0,05 a 1,0 segundo entre o etanol e o catalisador; temperatura entre $530-650^{\circ} \mathrm{C}$; pressão de $200-4000 \mathrm{kPa}$; e relação catalisador/etanol entre 10:1 e 100:1.

A eficiência de conversão de etanol em eteno neste processo é entorno de $84 \%$. Para a segunda zona de reação são verificadas as seguintes condições: temperatura entre $500^{\circ} \mathrm{C}$ e $620^{\circ} \mathrm{C}$; e, tempo de contato de 1,5 a 3,0 segundos. A relação estabelecida entre catalisador/hidrocarbonetos varia entre 5:1 e 20:1 (PINHO et al, 2008).

A corrente de saída da segunda zona do reator é composta por etano, água, gás combustível, GLP e gasolina, sendo esta posteriormente encaminhada a uma coluna de separação para a segregação dos componentes.

\subsection{Avaliação do Ciclo de Vida}

O reconhecimento dos limites da exploração de recursos naturais e da capacidade de suporte do meio ambiente em absorver rejeitos, aliado à crise de petróleo da década de 1970, impulsionou o desenvolvimento de iniciativas com enfoque em avaliar o saldo ambiental de produtos e serviços.

De acordo com Chehebe (2002), o primeiro estudo realizado para inventariar o desempenho ambiental de um produto, com vistas ao consumo de energia, matériasprimas, água, e em partes nas emissões geradas no processo de fabricação, ocorreu entre final da década de 1960 e início da década de 1970.

Tal trabalho, desenvolvido para a Coca-Cola Co. foi decorrente de uma mudança de atitude das organizações, pela busca de medidas preventivas quanto à ocorrência de impactos ambientais. Inicialmente denominado de Resource Enviromental Profile Analysis (REPA), o estudo levantou os consumos de energia e recursos do processo de fabricação das embalagens utilizadas para acondicionamento de refrigerante, a fim de selecionar aquela com melhor desempenho ambiental.

Aproximadamente um ano após a elaboração deste estudo, Hunt e Franklin identificaram a existência de outros dois inventários relativos ao consumo de energia no ciclo de vida de embalagens. 
Segundo Baumann e Tillman (2004) ambos as pesquisa foram conduzidos dentro do meio acadêmico, por universidades nos Estados Unidos. Entre as décadas de 1970 e 1980, o desenvolvimento de trabalhos para a quantificação dos consumos e impactos associados ao exercício da função de um produto disseminou-se por diversos países na Europa, viabilizando a fundamentação teórica necessária para a concepção do conceito de Avaliação do Ciclo de Vida (ACV).

Contudo, a falta de uma padronização metodológica dos estudos até então publicados, alimentava certo ceticismo por parte da academia científica, sobretudo, a respeito da credibilidade dos resultados apresentados nos estudos de ACV. Assim, a partir desta constatação, surgiram grupos de pesquisa que se propunham a proceder no aprimoramento de procedimentos confiáveis e exequíveis para a avaliação das interações entre um produto e o meio ambiente ao longo de seu ciclo de vida.

Como resultado desse esforço, contextualizava-se a técnica de Avaliação do Ciclo de Vida, cuja significância é ratificada em 1985, quando esta é recomendada pela Comunidade Europeia como método mais adequada para o auto-monitoramento dos consumos energéticos e de materiais em quaisquer empresas instaladas naquele continente.

Dada a relevância do tema, a SETAC - Society of Environmental Toxicology and Chemistry, organizou entre 1990 a 1993, cerca de nove conferências internacionais que resultaram na elaboração do SETAC Guidelines for Life Cycle Assessment: a Code of Practice, sendo este o primeiro documento voltado à padronização da metodologia da ferramenta (MOURAD, GARCIA e VILHENA, 2002).

Subsidiado pelo trabalho da SETAC, a International Organization for Standardization (ISO), em 1996, decidiu pela normatização e a padronização das práticas e condutas de realização de estudos de Avaliação do Ciclo de Vida. Segundo Sousa (2008), a série ABNT NBR ISO 14040 reservada para a ACV resultou, até o ano de 2006, nas normas técnicas que se seguem:

ABNT NBR ISO 14040: Avaliação do Ciclo de Vida: Princípios e Estrutura (1997);

- ISO 14041: Avaliação do Ciclo de Vida: Definição de Objetivo e Escopo e Análise de Inventário (1998);

- ISO 14042: Avaliação do Ciclo de Vida: Avaliação de Impacto do Ciclo de Vida (2000);

- ISO 14043: Avaliação do Ciclo de Vida: Interpretação do Ciclo de Vida (2000); 
- ISO 14047: Avaliação de Impacto do Ciclo de Vida: Exemplos de Aplicação da ISO 14042 (2001);

- ISO 14048: Avaliação do Ciclo de Vida: Formato de dados e documentação (2006); e,

- ISO 14049: Avaliação do Ciclo de Vida: Exemplos de Aplicação da ISO 14041 (2006).

A partir de 2006, as normas ABNT NBR ISO 14040, ISO 14041, ISO 14042 e ISO 14043 foram compiladas na forma revista da norma ABNT NBR ISO 14040 (2009) e pela criação da ABNT NBR ISO 14044 (2009). Tais documentos normativos tratam respectivamente de Princípios e Estrutura; e, Requisitos e Diretrizes da Avaliação do Ciclo de Vida.

\subsubsection{ACV: Conceito e Definição}

Silva e Kulay (2006) explicam que a ACV pode ser entendida como uma técnica de avaliação quantitativa, voltada à determinação dos impactos ambientais associados ao exercício da função de um produto, processo ou serviço.

Neste âmbito, o conceito ciclo de vida é utilizado para expressar todas as etapas e processos de um sistema de produto ou serviço, o que pressupõe a inclusão de toda a cadeia de obtenção de recursos naturais, produção, consumo, transporte, reciclagem e disposição final, quanto ao uso de recursos energéticos e materiais entradas - e a geração de rejeitos e subprodutos - saídas -, como representado na Figura 9.

Assim, a ACV permite quantificar e avaliar as interações do ciclo de vida de um produto com o meio ambiente, as quais são denominadas de aspectos ambientais pela ABNT (2009), enquanto o termo impacto ambiental designa as modificações do meio ambiente decorrentes dessas mesmas interações. 
Meio ambiente

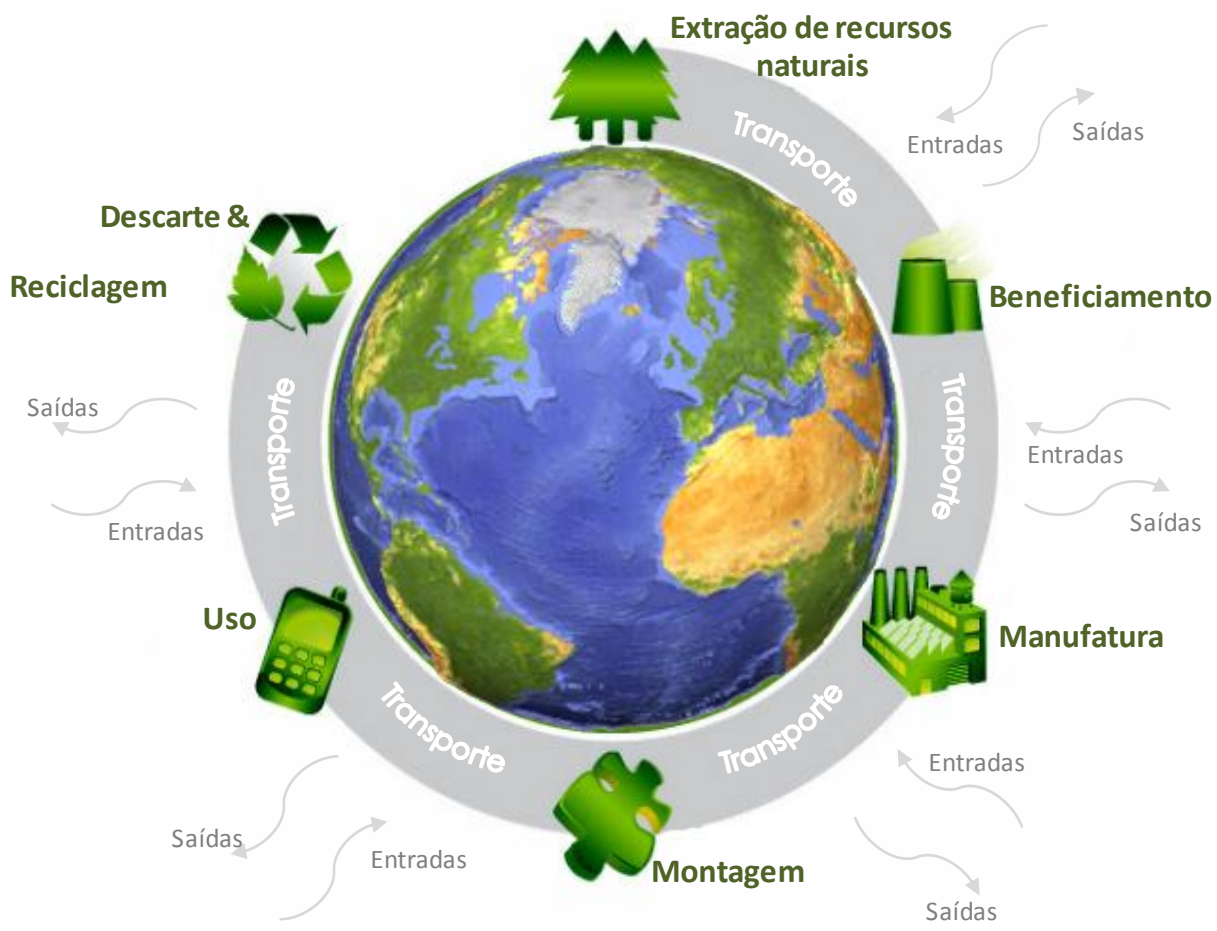

Figura 9: Esquema da Análise de Ciclo de vida de um produto

\subsubsection{Usos e aplicações}

Atualmente, a expansão do interesse pela metodologia da Avaliação do Ciclo de Vida coincide com a diversidade de aplicação e uso da ferramenta pelos setores industriais, empresariais, governamentais, órgãos reguladores, organizações não governamentais (ONGs) e consumidores.

Nesse sentido, são verificadas distintas vertentes de aplicação da ACV. São elas: a identificação de oportunidades de melhoria de desempenho ambiental; comparação de desempenho ambiental de produtos com mesma função; concessão de rótulos ou selos; projeto de novos produtos e processos, ou remodelação dos já existentes, a partir da variável ambiental; comunicação ambiental; entre outras (SILVA e KULAY, 2006).

$\mathrm{Na}$ primeira vertente, a ACV é conduzida com o intuito de aprimorar processos e produtos pela busca de novos insumos, fontes alternativas de energia ou tecnologia. 
Isto por que, a técnica permite explorar as características de desempenho ambiental para cada etapa do ciclo de vida do objeto em estudo, permitindo identificar a origem dos impactos ambientais mais significativos. De forma similar, a ACV pode ser adotada como meio de verificação de desempenho de processos de novos produtos, de forma que este seja concebido com melhor desempenho ambiental que seu predecessor para o exercício de uma mesma função.

A ACV se propõe também a fornecer dados quantitativos de desempenho ambiental para a verificação de atendimento de critérios estabelecidos por selos ou rótulos desenvolvidos por governos, ONGs ou até mesmo pela indústria. Esta aplicação é fortemente utilizada para difundir informações aos consumidores e usuários dos produtos, de forma que estes possam atribuir ao seu critério de escolha a matéria ambiental (BAUMNN e TILLMAN, 2004).

Por fim, a ACV permite identificar estratégias que possam alterar o desempenho ambiental de produtos ou processos que cumprem a mesma função por meio de comparações. Neste cenário, as análises têm como objetivo verificar que estratégias diferenciam um produto do outro em termos ambientais. A minimização de rejeitos no processo, ações de prevenção à poluição, capacidade de reuso, reciclabilidade e substituição de insumos são algumas das causas potenciais de mudança de desempenho ambiental que podem ser identificadas a partir do uso da ACV (SILVA e KULAY, 2006).

\subsubsection{Limitações}

Mesmo com a existência de normas que norteiam o desenvolvimento de estudos de $A C V$, esta ferramenta apresenta algumas limitações vinculadas tanto ao seu caráter metodológico quanto a necessidade de um amplo número de dados (SUGAWARA, 2012).

Assim, conforme identifica a norma ISO 14040 (ABNT, 2009), a subjetividade das decisões aplicadas aos estudos, seja na definição dos limites do sistema, ou na origem de dados e escolha das categorias de impacto, propicia em incertezas diretamente relacionadas ao aspecto metodológico da ferramenta.

Ainda nesse sentido, a inexistência de critérios universais para a padronização das terminologias, método de execução e formato dos dados, podem ocasionar na distorção dos resultados finais dos estudos (SILVA e KULAY, 2006). 
Chehebe (2002) ressalta de forma complementar que os resultados da ACV estão diretamente atrelados às condições técnicas, ambientais e geográficas do local onde o objeto de estudo foi concebido, processado, manufaturado e descartado. Desta maneira, as informações adotadas e as categorias de impacto selecionadas são específicas para cada ACV.

Guinée et al. (2001) colocam neste contexto, que a ACV é direcionada para as características físicas das atividades industriais e processos econômicos, não englobando mecanismos de mercado e efeitos secundários decorrentes do desenvolvimento tecnológico.

Em paralelo a estas questões, está a ausência de dados de apoio. Segundo Ribeiro (2009), apesar de alguns países terem investido na criação de banco de dados, estas mesmas informações não estão uniformizadas em uma única estrutura e, por vezes, apresentam-se obsoletas, incomparáveis ou de qualidade desconhecida.

Com isso, a fim de contornar tais limitações, Kulay (2004) ressalta a importância de esforços intelectuais para a consolidação de um método de execução da ACV que, por consequência, propicie o desenvolvimento de um banco de dados com estudos consistentes e reprodutíveis. Ribeiro (2009) defende, ainda, que a divulgação da técnica como ferramenta ambiental pode estimular empresas, associações e governo na coleta e oferta de informações ambientais sobre produtos e serviços, colaborando para que à abrangência de dados na ACV não seja um problema e, sim, uma possibilidade de aprimoramento dos resultados finais dos estudos.

\subsubsection{Método para operacionalização da ACV}

Conforme já mencionado, as características metodológicas de desenvolvimento dos estudos de ACV foram regulamentadas por um conjunto de normas que constituem a família ABNT NBR ISO 14040.

Segundo Ribeiro (2009), esta metodologia é, basicamente, um conjunto de etapas que visam identificar os aspectos ambientais resultantes do ciclo de vida de um produto e avaliar os potenciais impactos associados a estes aspectos.

Para tanto, a norma ABNT NBR ISO 14040 (2009) defini quatro fases para o desenvolvimento do estudo, quais sejam: [1] definição do objetivo e escopo; [2] análise do inventário; [3] avaliação de impactos ambientais; e, [4] interpretação dos 
resultados. Estas ações aparecem encadeadas de maneira lógica e iterativa como mostra o gráfico indicado pela Figura 10 a seguir.

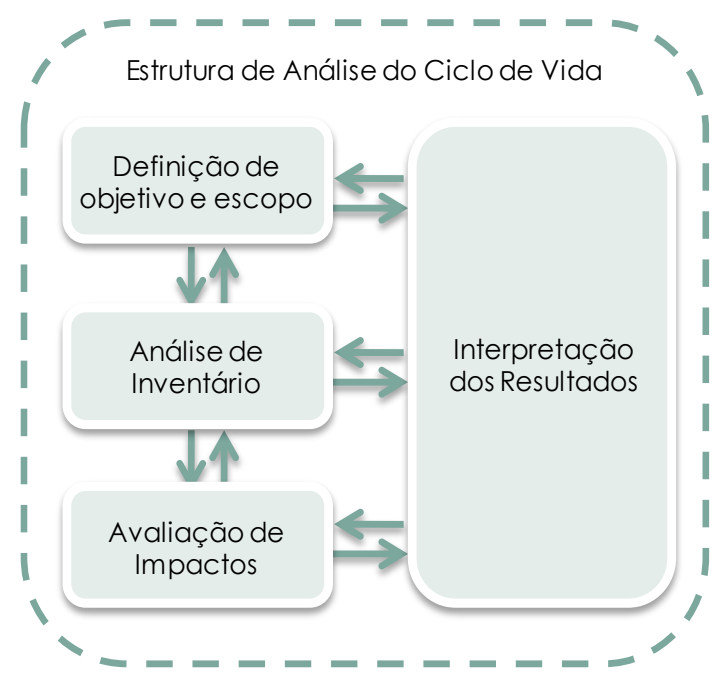

Figura 10: Estágios do estudo de ACV (adaptado da norma ABNT NBR ISO 14040, 2009).

O antes mencionado caráter de iteratividade da ACV aparece representado pelas setas duplas constantes da Figura 10.

Ao interligarem as fases executivas do método, estas permitem a revisão das definições previamente estabelecidas pelo estudo para atendimento de suas metas, bem como a adequação de dados para que estes estejam em consonância com o objetivo e escopo pretendidos.

\subsubsection{Definição de Objetivo e Escopo}

Em linhas gerais, a etapa de definição de objetivo e escopo tem por finalidade apresentar o objeto em estudo, os motivos pelos quais o estudo será desenvolvido, bem como o seu público alvo.

De acordo com Sugawara (2012), a definição clara do objetivo do estudo é fundamental para o sucesso da ACV. Isto porque, é nesta primeira etapa que ocorre a definição das premissas de escopo que irão balizar o desenvolvimento do inventário e da avaliação de impactos.

Assim, a fim de subsidiar as dimensões da ACV, segundo a ABNT NBR ISO 14040 (2009), quatorze elementos devem ser definidos, dentre eles os que seguem abaixo: 
a. Função do sistema de produto:

Estabelece o uso do produto em análise e qual sua função. Usualmente a função é expressa por um verbo plausível de quantificação.

b. Sistema de produto:

Conjunto de processos elementares conectados entre si por meio de fluxos materiais e energéticos, a partir do qual será realizada a função previamente definida.

Os fluxos constantes em cada processo elementar podem ser compostos por entradas sem prévia transformação antrópica, ou por materiais e energia derivados de outros processos elementares (fluxo de produto).

c. Unidade Funcional (UF):

Quantifica a função definida ao produto de acordo com o escopo da ACV. Este valor pode ser entendido como a base de cálculo para a quantificação das entradas e saídas do sistema. Trata-se de um valor arbitrário.

\section{d. Fluxo de referência:}

Quantidade de produto necessária para atender a unidade funcional estabelecida para o estudo. Assim, o fluxo de referência está diretamente relacionado ao desempenho técnico do produto no atendimento de sua função, sendo, portanto, o resultado a multiplicação da unidade funcional pelo desempenho técnico.

\section{e. Fronteiras do Sistema de Produto:}

Delimita a abrangência do estudo, em relação ao sistema natural, a outros sistemas (como produção de insumos e subprodutos), e fronteiras geográfica, temporal e de bens de capital (infraestruturas que serão incorporadas). Nesse sentindo, a fronteira delimita o conjunto de processos elementares que proporcionam o atendimento da função previamente definida e que modela o ciclo de vida de um produto.

Por este motivo, a definição da fronteira de produto é realizada por modelos representativos da realidade, de forma a obedecer a um critério de precisão dos resultados (SILVA e KULAY, 2006). Para Baumann e Tillman (2004), o mecanismo que melhor ilustra as fronteiras do sistema de produtos é o diagrama de blocos. Neste modelo de representação, cada bloco representa um processo elementar, indicando seus fluxos de entrada e saída e suas inter-relações. 
f. Critérios de exclusão de dados:

Rotinas quantitativas utilizadas para selecionar os aspectos ambientais a serem considerados em cada processo elementar que compõe o sistema de produto. De acordo com a ABNT NBR ISO 14040 (2009), os critérios de exclusão podem ser baseados nas representatividades mássicas e energéticas dos fluxos de entrada e saída, quando estes são avaliados sob o enfoque de contribuição quantitativa; ou, em premissas de relevância ambiental, as quais avaliam a significância qualitativa dos fluxos excluídos em relação ao resultado final do estudo.

\section{g. Procedimentos de alocação:}

Válido apenas para estudo de ACV de enfoque dito atribucional, estes procedimentos buscam distribuir as contribuições dos fluxos de entrada e saída e, consequentemente, os impactos ambientais associados a estes, entre os diferentes produtos. Para tanto, são empregados critérios diversos baseados em componentes físicas - como massa, volume e capacidade calorífica -; ou em premissas econômicas.

Mecanismos de alocação são necessários em três cenários clássicos: [1] quando um processo é compartilhado por vários produtos, como é o caso das refinarias, nas quais um único processo resulta em diversos produtos energéticos e não energéticos; [2] quando sistemas são compartilhados por diferentes processos, tal como acontece em polos petroquímicos, onde sistemas de tratamento de efluentes são compartilhados entre diferentes indústrias que manufaturam produtos distintos; e, [3] quando materiais são reciclados em sistemas de produtos diferentes (BAUMANN e TILLMAN, 2004).

\section{h. Requisitos de qualidade:}

Especifica as características dos dados necessários ao estudo para alcance dos objetivos pré-estabelecidos, incluindo os seguintes parâmetros: período de tempo coberto; área geográfica; tecnologias envolvidas; precisão, completeza e representatividade dos dados; reprodutibilidade dos métodos usados ao longo da ACV; fonte dos dados e incertezas da informação.

Destaca-se que as perspectivas temporais, geográficas e tecnológicas dos dados, conjuntamente, podem ser analisadas perante o aspecto de relevância das informações. 
Esta consideração pode ser exemplificada em situações quando a adoção de dados primários é entendida como a fonte de informação mais adequada para a análise de melhoria de um processo industrial específico, enquanto que o uso de dados médios secundários pode ser uma melhor opção para o conhecimento da carga ambiental de uma matéria-prima adquirida de um amplo grupo de fornecedores (BAUMANN e TILLMAN, 2004)

Ainda sobre os parâmetros mencionados, Ribeiro (2009) explica que a precisão mede a variabilidade dos dados e a completeza relaciona a quantidade de dados primários relatados pela quantidade de dados potenciais existentes em um processo elementar. Quanto a reprodutibilidade, Baumann e Tillman (2004) explicam que esta está vinculada ao nível de transparência da ACV. Quanto maior o detalhamento das informações apresentadas, melhor será a característica de reprodutibilidade do estudo.

i. Metodologia para a avaliação de impacto:

Define quais categorias de impacto, indicadores e modelo de avaliação de impactos ambientais serão utilizados no estudo de ACV de acordo com o seu propósito.

\section{j. Limitações}

Descreve as limitações encontradas no decorrer do estudo, sejam estas de caráter temporal, econômico ou de qualidade de dados.

\section{k. Análise crítica:}

Verifica se o estudo satisfez os requisitos adotados quanto à metodologia, aos dados e ao relatório.

Além dessas definições, esta fase inicial do estudo deve contemplar eventuais suposições incorporadas para o andamento da ACV, de forma a relatar de forma fiel, completa e consistente os resultados do trabalho. 


\subsubsection{Análise de Inventário}

Santos (2005) explica que a análise do inventário do ciclo de vida (ICV) é um procedimento sistemático, gradual e objetivo para quantificar os aspectos ambientais no ciclo de vida. O primeiro procedimento a ser realizado nesse âmbito é a coleta de dados, de modo que esta consiga ser revertida em fluxos de entrada de matéria e energia para cada um dos processos elementares e de saída destes para o meio ambiente.

Para tanto, devem ser providenciadas ações prévias a esta incursão, como a construção do fluxograma de processo, a elaboração de dispositivos para coleta e registro de dados e a descrição do objeto em estudo.

Os dados utilizados para estudo podem ser obtidos em campo (dados primários) ou em literatura (dados secundários).

Dados quantitativos utilizados na comparação de materiais ou processos e dados qualitativos empregados para a descrição de aspectos ambientais ou etapas não quantificáveis, podem ser selecionados a partir da aplicação dos critérios de exclusão de dados (ABNT NBR ISO 14044, 2009).

Após a coleta, os dados são tratados, a fim de adequá-los ao fluxo de referência do objeto em estudo. Nesse instante, devem também ser incorporados os critérios de alocação previamente estabelecidos na etapa de definição de objetivo e escopo, para que haja a correta ponderação dos fluxos de entrada e saída dos processos elementares.

Visto a característica iterativa da metodologia, Ribeiro (2009) destaca que durante a execução do inventário, é necessária a realização de análises de sensibilidade para eventuais redefinições da fronteira do sistema, exclusão de aspectos ambientais, ou de processos elementares identificados como não significativos para o estudo.

O produto final da etapa corresponde a uma planilha contendo aspectos ambientais, ou seja, valores de consumo de recursos naturais e energéticos, bem como de emissões para o ar, água e solo resultantes do exercício da função previamente estabelecido para o produto em análise. 


\subsubsection{Avaliação de Impactos Ambientais}

A Avaliação de Impactos Ambientais do Ciclo de Vida (AICV) analisa a magnitude e significância dos impactos ambientais potenciais sobre o meio ambiente e sobre o ser humano, relacionados ao atendimento da função exercitada pelo produto, processo, ou serviço.

De acordo com a norma NBR ISO 14044 (2009), a AICV é composta por elementos obrigatórios e opcionais, conforme apresenta a Figura 11.

Elementos Obrigatórios

Seleção das categorias de impacto, indicadores de categoria e modelos de caracterização

Correlação dos resultados do ICV [classificação]

Cálculo dos resultados dos indicadores de categoria [caracterização]

Perfil do AICV

[RESULTADOS DO INDICADOR DE CATEGORIAS]

Elementos Opcionais

Cálculo da magnitude dos resultados [Normalização]

Agrupamento

Ponderação

Análise da qualidade dos dados

Figura 11: Elementos da fase da AICV (ABNT, 2009)

\subsection{Seleção das categorias de impacto}

De acordo com Pereira (2004), a seleção das categorias de impacto ambiental deve ser baseada nos resultados do inventário, com vistas aos aspectos ambientais mais relevantes para o estudo, segundo as considerações previamente feitas durante a fase de objetivo e escopo. Neste momento, também são definidos os indicadores ambientais e os modelos de caracterização a serem posteriormente utilizados nas etapas obrigatórias subsequentes da AICV. 
Ferreira (2004) lista premissas que devem ser consideradas durante a seleção das categorias de impacto:

- As categorias devem permitir uma avaliação abrangente dos principais impactos resultantes dos fluxos de entrada e saída calculados no inventário do ciclo de vida;

- As categorias devem evitar sobreposição de impactos;

- As categorias devem ser reconhecidas e aprovadas internacionalmente;

- O número de categorias de impacto não deve ser excessivo, a fim de reduzir a complexidade do estudo e possibilitar melhor análise crítica dos resultados.

A quantificação dos resultados das categorias de impacto é realizada com base no estabelecimento de indicadores que estabelecem uma medida comum e científica para a conversão dos valores dos aspectos ambientais.

A profundidade com que os impactos são avaliados é definida por meio da adoção de indicadores intermediários - midpoints - e indicadores finais - endpoints.

O primeiro grupo de indicadores, midpoint, restringe-se a analisar os efeitos primários diretos ocasionados pela disposição e consumo de um determinado aspecto ambiental. Portanto, a modelagem do tipo midpoint resulta em avaliações menos complexas, abarcando potenciais de aquecimento global, toxicidade humana, depleção de recursos naturais, dentre outros (KULAY, 2004). Já os indicadores finais, denominados endpoints, visam avaliar os efeitos finais da cadeia de causa e efeito sobre o meio ambiente e a saúde humana (SUGAWARA, 2012).

Monteiro (2008) exemplifica o indicador endpoint com a categoria de mudanças climáticas, a qual representa as emissões de gases efeito estufa utilizando a radicação infravermelha como indicador ambiental. Neste caso, diferentes ordens de impacto são contempladas no estudo, tais como: a perturbação no balanço da radiação; o aumento da temperatura global; o derretimento das camadas de gelo e o consequente aumento no nível dos oceanos.

\subsection{Categorias de impacto}

As categorias de impacto descritas a seguir compõem parte daquelas comumente utilizadas na realização de estudos de ACV: 
- Acidificação: ocorre a partir da emissão de substâncias solúveis em água que, em primeira estância, ocasionam na redução do $\mathrm{pH}$ das chuvas. Dentre as causas de ordem secundária, tem-se: a alteração do teor de acidez do solo e degradação de patrimônios e da vida aquática. Os Potenciais de Acidificação são expressos em $\mathrm{kg}$ de $\mathrm{SO}_{2}$ equivalente/ kg de emissão, com horizonte temporal é infinito e a escala geográfica varia entre local e continental.

- Eutrofização: refere-se ao enriquecimento de corpos hídricos e do solo por disposição de nutrientes, que eleva a produção de biomassa nesses meios. $O$ excesso de biomassa ocasiona no aumento da taxa de consumo de oxigênio livre pelo processo de decomposição da matéria, alterando as condições naturais desses ambientes e afetando a biodiversidade local. O Potencial de Eutrofização é expresso como $\mathrm{kg}$ de $\mathrm{P}$ equivalente $/ \mathrm{kg}$ de emissão.

- Mudanças Climáticas: representa o aumento da radiação infravermelha na superfície terrestre, proveniente em especial da crescente quantidade de $\mathrm{CO}_{2}$, $\mathrm{N}_{2} \mathrm{O}, \mathrm{CH}_{4}$, aerossóis e outros gases na atmosfera, que impedem a dispersão dos raios solares. O potencial de aquecimento global é expresso em kg de dióxido de carbono equivalente/ kg de emissão.

- Depleção Abiótica: representa a redução de recursos naturais não bióticos que são utilizados como insumos no sistema de produto, como combustíveis fósseis e minérios. O fator de depleção abiótica é baseado na relação oferta global de recursos versus consumo.

- Depleção da camada de ozônio: redução da camada de ozônio existente na estratosfera, que permite a passagem de radiação ultravioleta à superfície terrestre, aumentado a ocorrência de problemas de pele, doenças oculares e interferências no ecossistema. O modelo de caracterização utilizado para medir impactos dessa natureza foi desenvolvido pela Organização Meteorológica Mundial (WMO) e define o Potencial de Depleção de Camada de Ozônio de diferentes gases em termos de kg de CFC-11 equivalente/kg de emissão.

- Toxicidade humana: emissão de substâncias tóxicas no ar, solo ou água, como compostos aromáticos, metais, dentre outros, que podem causar problemas à saúde do homem quando inaladas ou ingeridas. 
Os fatores de caracterização, expressos como potenciais de toxicidade humana, são calculados a partir do USES-LCA, considerando critérios como destino, exposição e efeitos das substâncias tóxicas para um horizonte de tempo infinito, expressos em 1,4 diclorobenzeno equivalente/kg de emissão.

- Ecotoxicidade Terrestre: diz respeito ao impacto causado sobre ecossistemas terrestres por substâncias tóxicas emitidas para o ar, solo ou água. Algumas das consequências finais deste impacto são a redução da produção agrícola e biodiversidade da flora e da fauna. O Potencial de Ecotoxicidade é expresso como equivalentes a 1,4 diclorobenzeno $/ \mathrm{kg}$ de emissão.

- Formação Fotoquímica de Ozônio: nevoeiro decorrente da reação fotoquímica entre óxidos de nitrogênio e sustâncias orgânicas voláteis, que podem diminuir a atividade de fotossíntese da flora pela redução de luminescência solar. Os fatores de Potencial de Formação de Oxidantes Fotoquímicos são calculados em $\mathrm{kg}$ de etileno equivalente / $\mathrm{kg}$ de emissão.

\subsection{Classificação}

O agrupamento qualitativo dos aspectos ambientais em relação às categorias de impacto é realizado na etapa de classificação.

Tal atividade é necessária, uma vez que diferentes aspectos podem contribuir para impactos distintos, sendo esta característica avaliada cientificamente. Neste sentido, os fluxos elementares são associados a um indicador midpoint, cujas informações são posteriormente ordenadas em indicadores finais - endpoints, tal como ilustra a Figura 12 (UNEP, 2011).

Os fluxos de entrada e saída dos processos elementares podem ser contabilizados integralmente mais de uma vez durante a classificação, desde que os impactos ocasionados sejam independentes um do outro (JENSEN et.al., 1997).

Em contra partida, para os casos em que um único aspecto contribui para categorias dependentes, a ABNT (2009) sugere realizar mecanismos distributivos. 


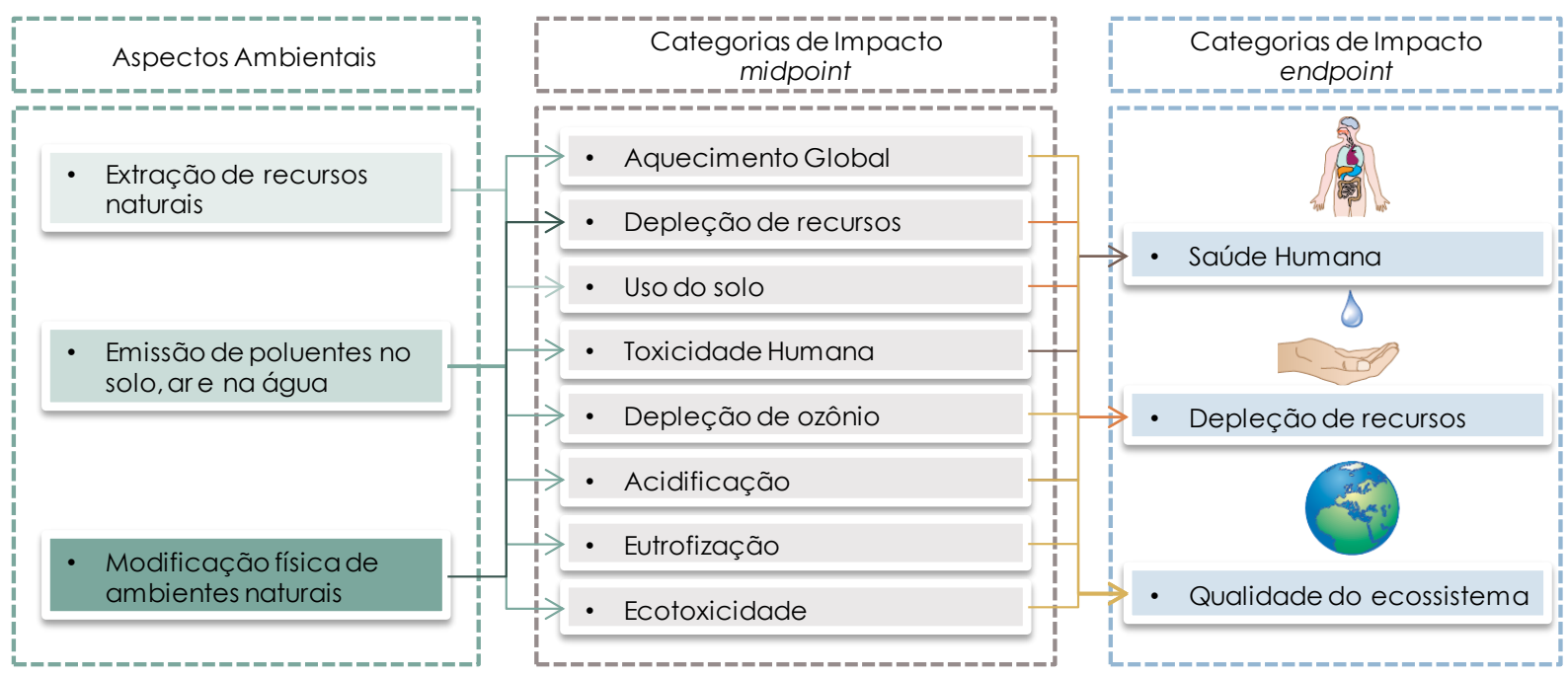

Figura 12: Fluxograma esquemático da classificação dos aspectos em categorias de impacto (adaptado de UNEP, 2011).

\subsection{Caracterização}

Após a classificação, os resultados obtidos no inventário são correlacionados quantitativamente na etapa de caracterização.

A quantificação dos resultados para cada categoria de impacto é realizada com base no estabelecimento de fatores de referência, os quais são representados algebricamente por um composto capaz de expressar a magnitude de contribuição das demais substâncias na referida categoria. Este composto é utilizado como base de comparação científica para a determinação dos fatores de equivalência para cada substância dentro de cada categoria de impacto.

Assim sendo, o impacto ambiental total da categoria é expresso pela Equação 8 que aparece indicada a seguir:

$$
S_{J}=\sum_{I} Q_{J I} \times m_{i}
$$

Onde:

$S_{j}=$ impacto total da categoria $\mathrm{j}$;

$\mathrm{m}_{\mathrm{i}}=$ quantidade da carga ambiental (i) associada aos fluxos de matéria e energia calculados no inventário;

$\mathrm{Q}_{\mathrm{ji}}=$ fator de equivalência para a carga ambiental (i) na categoria de impacto (j). 
A composição dos desempenhos ambientais para as categorias de impacto resulta no chamado Perfil de Impacto Ambiental, última atividade obrigatória da fase de AICV.

\subsection{Normalização}

A normalização do perfil de impacto ambiental tem por objetivo relacionar os resultados das categorias de impacto a uma situação de referência, fornecendo informações sobre sua significância relativa.

De acordo com Ferreira (2004), esta relação ocorre por meio da divisão da carga total de uma categoria de impacto pela magnitude real desta mesma categoria. Alguns exemplos de fatores de normalização são: a utilização de recursos por uma dada área global, regional ou local; as emissões ou consumos totais em uma dada área em base per capita; ou a razão entre o valor de uma alternativa e outra.

Assim, em meio às comparações possíveis, o desenvolvimento da normalização permite identificar a representatividade do impacto ambiental causado pelo objeto em estudo para uma categoria específica, perante o impacto total causado por todos os processos produtivos de um país para a mesma categoria de impacto.

Passuello (2007) exemplifica esta possibilidade por meio das emissões de dióxido de carbono de um produto. Nesse caso, o objeto em estudo emite 1 tonelada de $\mathrm{CO}_{2}$ equivalente, enquanto que a contribuição anual do país onde este é manufaturado é de 1 milhão de toneladas de $\mathrm{CO}_{2}$ equivalente. Assim, a contribuição normalizada do produto é $10^{-6}$ ano, ou 31,5 segundos.

O perfil de impacto ambiental normalizado é produto final desta etapa, que apresenta uma série limitações. Dentre elas tem-se, principalmente, a dificuldade de obter valores confiáveis que, quando não fiéis à realidade, podem alterar significativamente os resultados do estudo (SUGAWARA, 2012).

\subsection{Agrupamento}

A etapa de agrupamento tem por objetivo reordenar as categorias de impacto. Esta atividade, de acordo com a ABNT NBR ISO 14044 (2009), pode ser realizada a partir de duas premissas distintas: 
[1] agrupando as categorias que apresentam características comuns, como abrangência geográfica local, regional ou global; ou, [2] organizando as categorias de impacto segundo um critério de importância relativo e não numérico.

Baumann e Tillman (2004) colocam que o agrupamento possui benefícios quanto à apresentação dos resultados, ordenando as informações de maneira mais compreensível ao leitor. Monteiro (2008) comenta que o uso de fatores de impacto pode comprometer a clareza e confiabilidade dos resultados por não considerar as condições locais onde os impactos foram gerados.

\subsection{Ponderação}

A ponderação pode ser definida como um método qualitativo ou quantitativo, no qual as categorias de impactos são relacionadas entre si para a avaliação de sua importância. O intuito desta atividade é criar um indicador único de desempenho ambiental para o objeto de estudo. Critérios sociais e científicos, dentre outros princípios, são adotados para o desenvolvimento de fatores de peso que se diferem conforme o país de origem (RIBEIRO, 2009). Destacam-se entre os critérios:

- Monetização: avaliação econômica, cuja abordagem visa atribuir custos aos impactos ambientais ou preços pela modificação da qualidade ambiental. $O$ preço pode ser resultado da "disposição a pagar" dos indivíduos afetados pelos prejuízos ambientais ocasionados pelo atendimento da função do objeto em estudo. Esta abordagem é baseada em valores e preferências sociais.

- Limites projetados: resultado da diferença entre os níveis atuais de poluição e os limites desejados, definidos por autoridades ambientais ou por padrões internos de uma companhia.

- Abatimento tecnológico: método que estuda a possibilidade de redução da carga ambiental por meio da adoção de diferentes tecnologias.

- Painéis sociais: emprega a opinião de acadêmicos e autoridades interessadas para a definição de fatores de peso entre as categorias de impacto.

A ponderação pode ser realizada a partir da aplicação da Equação 9 apresentada a seguir (FERREIRA, 2004): 


$$
X=\sum_{j} W_{j} x N_{J}
$$

Onde:

$\mathrm{X}=$ índice ambiental;

$\mathrm{W}_{\mathrm{j}}=$ fator de ponderação para a categoria de impacto $\mathrm{j}$;

$\mathrm{N}_{\mathrm{j}}=$ resultado normalizado do impacto $\mathrm{j}$.

A subjetividade é uma característica inerente ao processo de ponderação, visto que esse envolve a adoção de premissas sociais baseadas na importância e na relevância percebidas (BAUMANN e TILLMAN, 2004). Contudo, Ferreira (2004) afirma que a ponderação pode assumir um perfil racional com o uso de teorias de decisão, as quais são desenvolvidas cientificamente.

\subsection{Métodos de Avaliação de Impactos Ambientais}

A etapa da AICV pode ser facilitada a partir do uso de métodos já desenvolvidos por grupos científicos e instituições do setor, em que as informações sobre os aspectos ambientais quantificados no inventário são agrupadas de acordo com indicadores de caracterização ou mesmo em um índice único. Baumann e Tillman (2004) ressaltam que cada método possui princípios de mensuração particulares e, portanto, a sua escolha influência diretamente o resultado final obtido.

Em métodos de caracterização, a escala é baseada em propriedades físico-químicas dos poluentes, enquanto que nos métodos de ponderação também são utilizados critérios que representam preferências sociais, por exemplo.

A seguir estão descritos alguns dos principais métodos identificados nas literaturas sobre Avaliação do Ciclo de Vida.

\subsection{CML - Center of Environmental Science}

O CML é um método de avaliação de impactos desenvolvido por um grupo de cientistas do Centro de Ciências Ambientais da Universidade de Leiden - Holanda. 
Esta metodologia define tanto fatores de caracterização quanto de normalização, este último proposto para quatro coberturas geográficas e temporais distintas, quais sejam: Holanda - 1997; Europa Ocidental - 1995; Mundo - 1990 e 1995.

O método de caracterização é enquadrado em indicadores midpoint, contemplando os seguintes impactos ambientais: acidificação; mudanças climáticas; eutrofização; ecotoxicidade de água doce; ecotoxicidade marinha; ecotoxicidade terrestre; toxicidade humana; formação de oxidantes fotoquímicos; depleção da camada de ozônio; radiação ionizante; depleção de recursos abióticos e uso do sol (ECOIVENT, 2007).

De acordo com Monteiro (2008), o método CML é um modelo de avaliação de impactos que não é só consistente, como também descreve os efeitos sobre o meio ambiente causados ao longo dos processos envolvidos de forma tal, que futuras ações gerenciais podem ser tomadas.

\subsection{Ecoindicator}

O Ecoindicator é um método de avaliação de impacto desenvolvido pela empresa Pré Consultants, cuja primeira versão foi publicada em 1995. Diferentemente do CML, o Ecoindicator faz uso de indicadores endpoint, contemplando as fases de normalização, ponderação e agregação para o desenvolvimento de um índice único de desempenho ambiental. Desta forma, o resultado final é apresentado em forma de pontuação, colaborando para a fase de interpretação dos resultados.

A primeira fase de análise deste método diz respeito ao cálculo do impacto ambiental causado pelos aspectos levantados durante o inventário do ciclo de vida, para as seguintes categorias: saúde humana; qualidade do ecossistema; e consumo de recursos.

O segundo procedimento faz uso de critérios de normalização baseados em dados médios da Europa Ocidental para a análise das categorias de impacto anteriormente citadas. Por fim, os procedimentos de ponderação são realizados a partir de fatores baseados em valores sociais (BAUMANN e TILLMAN, 2004).

Conforme apresenta Alvarenga (2010), a ponderação aplicada a este método é dividida nas três perspectivas representadas abaixo: 
- Igualitária: abordagem de longo prazo, sem qualquer comprovação científica para contemplar um modelo de caracterização;

- Individualista: abordagem de curto prazo, em que somente efeitos provados cientificamente sustentam a inserção de modelos de caracterização;

- Hierárquica: sugerida como padrão pelos autores do método, esta perspectiva adota fatores de ponderação acordados por especialista.

A partir dessas perspectivas, três índices distintos podem ser gerados. Entretanto, critérios de combinação podem ser adotados para incorporar os resultados desses índices em um único resultado global de desempenho ambiental.

Apesar dos autores do método reconhecerem que o mesmo não é representativo para toda a Europa, este é considerado pela academia como uma primeira etapa para o desenvolvimento de um conjunto de índices (BAUMANN e TILLMAN, 2004).

\subsection{3 $\mathrm{ReCiPe}$}

O ReCiPe é um método de análise que busca harmonizar os indicadores midpoint do CML e a abordagem endpoint do Ecoindicator em uma única metodologia, fornecendo resultados em ambos os níveis de categorias de impacto. Este método é fruto do trabalho desenvolvido por diversas instituições holandesas: Instituto Nacional de Saúde Pública; Centro de Ciências Ambientais da Universidade de Leiden; Departamento de Ciências Ambientais da Radboud University Nijmegen e a organização independente para consultorias CE Delft, possuindo particularidades nos princípios de modelagem aplicados (GOEDKOOP, et al. 2013). A escolha das categorias de impacto e de seus indicadores baseiam-se em três princípios:

- As categorias devem refletir o impacto ambiental direto. Assim, a geração de rejeito não é classificada como uma categoria de impacto. Por outro lado, os efeitos associados a disposição desse rejeito no ambiente são olhadas pelos modelos de avaliação de impactos. A mesma lógica vale para o consumo de recursos.

- As categorias midpoint são definidas por meio de mecanismos científicos que justificam a influência de uma variedade de substâncias em uma categoria de impacto específica. 
- Os indicadores são valores utilizados para caracterizar a magnitude de cada categoria de impacto.

No nível midpoint o método ReCiPe constitui-se de: [1] mudanças climáticas, [2] depleção da camada de ozônio, [3] acidificação terrestre, [4] eutrofização de água doce, [5] eutrofização de água marinha, [6] toxicidade humana, [7] formação de oxidantes fotoquímicos, [8] formação de material particulado, [9] ecotoxicidade terrestre, [10] ecotoxicidade de água doce, [11] ecotoxicidade marinha, [12] radiação ionizante, [13] ocupação de solo agricultável, [14] ocupação de solo urbano, [15] transformação do solo, [16] depleção de água, [17] depleção de recursos minerais e, [18] depleção de recursos fósseis. No nível endpoint, as categorias são agrupadas segundo os mesmos enfoques abordados pelo Ecoindicator: saúde humana; qualidade do ecossistema; e consumo de recursos. As relações entre as categorias de impacto midpoint e endpoint estão apresentadas na Tabela 12.

Tabela 12: Relação entre as categorias midpoint e endpoint no método $\operatorname{ReCiPe}^{5}$ (GOEDKOOP, et al. 2013).

\begin{tabular}{lccc}
\hline Categorias midpoint & $\begin{array}{c}\text { Saúde } \\
\text { Humana }\end{array}$ & $\begin{array}{c}\text { Categorias endpoint } \\
\text { Ecossistema }\end{array}$ & $\begin{array}{c}\text { Consumo de } \\
\text { Recursos }\end{array}$ \\
\hline Mudanças Climáticas (CC) & + & + & - \\
\hline Depleção da Camada de Ozônio (OD) & + & + & + \\
\hline Acidificação Terrestre (TA) & - \\
\hline Eutrofização de água doce (FE) & + & - \\
\hline Eutrofização marinha (ME) & + & + \\
\hline Toxicidade humana (HT) & + & + \\
\hline Formação de oxidantes fotoquímicos (POF) & + \\
\hline Formação de material particulado (PMF) & + \\
\hline Ecotoxicidade terrestre (TET) & + & + \\
\hline Ecotoxicidade de água doce (FTE) & + \\
\hline Ecotoxicidade marinha (MET) & & + \\
\hline Radiação lonizante (IR) & & + \\
\hline Ocupação de solo agricultável (ALO) & \\
\hline Ocupação de solo urbano (ULO) & + \\
\hline Transformação de solo natural (NLT) & + \\
\hline Depleção de água (WD) & & - \\
\hline Depleção de recursos minerais (MRD) & & - \\
\hline Depleção de recursos fósseis (FD) & & + \\
\hline
\end{tabular}

\footnotetext{
${ }^{5}$ As categorias demarcadas com o símbolo "+" representam aquelas cujas relações quantitativas foram incorporadas no $\mathrm{ReCiPe} 2008$; as categorias demarcadas com o símbolo "-" representam aquelas que, apesar da conexão, não foram relacionadas quantitativamente.
} 


\subsubsection{Interpretação dos Resultados}

O conjunto dos indicadores de categoria de impacto forma o perfil ambiental do produto, a ser analisado na última fase da ACV, de Interpretação dos resultados. Esta etapa de análise crítica objetiva combinar, resumir e discutir as constatações da análise de inventário e da avaliação de impacto, de maneira iterativa aos objetivos e escopo da ACV, bem como da natureza e da qualidade dos dados coletados.

A fase de interpretação da ACV compreende identificar dos temas de maior relevância ambiental, avaliando os resultados do estudo para o estabelecimento de recomendações e conclusões.

O desenvolvimento minucioso de todas as etapas relatadas, que por essência da metodologia estão inter-relacionadas, é fundamental para o êxito da ACV, evidenciando a abordagem holística dos impactos ambientais associados ao material de estudo. Desta forma, a ACV se apresenta como uma ferramenta importante dentro dos sistemas de gestão, discutindo com clareza e objetividade as questões ambientais relacionadas ao gerenciamento de recursos ambientais e à identificação de pontos críticos de processos e produtos, possibilitando a otimização de sistemas e materiais e o desenvolvimento de novas tecnologias.

\subsubsection{Trabalhos de ACV sobre poliestireno}

Para averiguar o uso da ACV em estudos de desempenho ambiental do poliestireno cristal e de alto impacto, efetuou-se ampla pesquisa em bases de dados acadêmicas, dentre as quais estão inclusas os Portais Periódicos da Coordenadoria para Aperfeiçoamento de Pessoal de Nível Superior (Capes), SpringerLink Database e Science Direct.

A busca por trabalhos desta natureza ocorreu a partir da combinação de termos tais como: "Life cycle Assessment", "polystyrene", "GPPS", "HIPS", "LCA", "Carbon footprint", "environmetal performance" e "environmental impacts".

Deste levantamento foram identificados 12 artigos que trazem resultados de desempenho ambiental do poliestireno, seja avaliando os impactos ocasionados até a produção da resina em si, ou em estudos que comparam-no a outras matérias- 
primas em especial, para embalagens. Os documentos listados nas bases de dados foram analisados de modo a estabelecer inter-relação entre os temas.

Ressalta-se que nenhum dos documentos encontrados avaliou as características de desempenho ambiental do poliestireno derivado de fontes renováveis, seja de forma parcial ou completa. Nesse sentido, todos os resultados identificados abarcam o processo convencional de manufatura, de origem petroquímica, no qual petróleo é refinado e processado até a obtenção da resina em estado polimérico.

O primeiro registro sobre avaliação de desempenho ambiental do poliestireno data da década de 1970. Segundo Baumann e Tillman (2004), tal trabalho visava obter informações sobre o impacto ambiental resultante da manufatura de bandejas de poliestireno e de papel para condicionamento de carne, comumente utilizadas na época.

Outros estudos similares a este foram realizados após o ano de 2000. No artigo publicado na Journal of Cleaner Production, Zabaniotou e Kassidi (2003) avaliaram a diferença de desempenho ambiental das embalagens de ovos produzidas a partir de papel reciclado e GPPS. A função e unidade funcional definidas pelos pesquisadores são de armazenar trezentos mil ovos em embalagens de seis unidades. Visto que cada embalagem de GPPS tem uma massa de 15 gramas, o fluxo de referência do estudo para as embalagens de poliestireno foi de 0,75 toneladas, enquanto que o fluxo de referência para a embalagem de papel foi de 1,2 toneladas.

As características tecnológicas de produção basearam-se na média dos países europeus, e as fronteiras do sistema de produto não incluíram as etapas de distribuição e uso, sendo o aterro o local de disposição final das embalagens.

A partir dessas definições de objetivo e escopo, o estudo obteve um perfil de impacto ambiental normalizado e ponderado para as seguintes categorias: mudanças climáticas (GNP), acidificação (AP), smog fotoquímico de verão (WS), smog fotoquímico de inverno (SS), metais pesados (HM), depleção da camada de ozônio (ODP), eutrofização (NP) e substâncias cancerígenas (CS). O método aplicado na AICV foi o ECO-Indicator 95, que define critérios de ponderação baseados em impactos médios no continente europeu, resultando no perfil de impacto apresentado na Figura 13. 


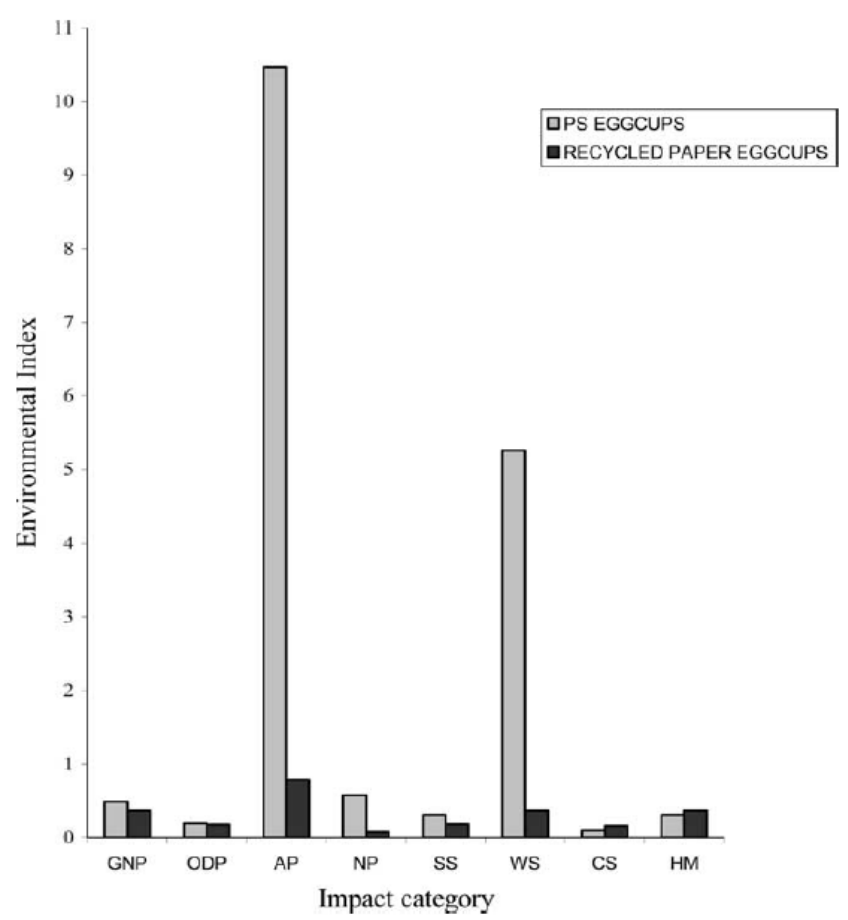

Figura 13: Perfil de desempenho ambiental das embalagens de ovos a partir de papel reciclado e GPPS (ZABANIOTOU e KASSIDI, 2003).

De acordo com o estudo, a embalagem de GPPS alcançou melhor desempenho em duas das oito categorias de impacto analisadas. Esta diferença, fundamentalmente, se deve ao processamento do petróleo e consumo de energia durante a manufatura do poliestireno (ZABANIOTOU e KASSIDI, 2003).

Mais recentemente, Madival et. al. (2009) realizaram a análise do perfil de desempenho ambiental de embalagens para morangos compostas por diferentes matérias-primas: PLA (Plástico Polilático), PET (Politereftalato de etileno) e poliestireno. A unidade funcional aplicada no estudo foi de 1000 embalagens com capacidade de $450 \mathrm{~g}$ cada, resultando em um fluxo de referência de $25 \mathrm{~kg}$ para o material à base de poliestireno.

A fronteira do sistema de produto incorporou desde a extração das matérias-primas, até a produção das resinas, formatação das embalagens e transportes. O inventário do ciclo de vida da extração à manufatura da resina de poliestireno foi obtido no banco de dados do Ecoinvent, o qual faz uso do perfil ambiental desenvolvido pela Associação de Plásticos Europeia - PlasticsEurope. O mesmo banco de dados foi utilizado para a fase de formatação das embalagens e consumo de combustíveis pelo transporte. 
Já as distâncias percorridas por estes entre cada uma das etapa do sistema de produto foram calculadas pelos pesquisadores com base nas características de mercado norte americanas. Os resultados dos perfis de desempenho ambiental das embalagens estão apresentados na Tabela 13.

Tabela 13: Perfil de desempenho ambiental de 1000 embalagens de morango (MADIVAL et. al., 2009)

\begin{tabular}{|c|c|c|c|c|}
\hline Categoria de Impacto & Unidade & POLIESTIRENO & PET & PLA \\
\hline Mudanças climáticas & $\mathrm{kg} \mathrm{CO} 2 \mathrm{eq}$ & 165 & 198 & 171 \\
\hline Potencial de acidificação & $\mathrm{kg} \mathrm{SO} 2 \mathrm{eq}$ & 1,04 & 1,14 & 1,82 \\
\hline Depleção da camada de ozônio & kg CFC-11 & 1,01E-05 & $1,79 \mathrm{E}-05$ & $1,45 \mathrm{E}-05$ \\
\hline Eutrofização & $\mathrm{kg} \mathrm{PO}_{4 \text { eq }}$ & 0,0094 & 0,0753 & 0,0160 \\
\hline Orgânicos respiráveis & $\mathrm{kg}$ eteno eq & 0,181 & 0,234 & 0,277 \\
\hline Partículas inaláveis & $\mathrm{kg} \mathrm{PM} 2.5$ & 0,206 & 0,246 & 0,294 \\
\hline Energia não renovável & MJ & 35.700 & 41.600 & 33.000 \\
\hline Ecotoxicidade Aquática & Kg TEGeq & 4090 & 4560 & 3984 \\
\hline Ocupação do solo & $\mathrm{m}^{2}$ & 2,4 & 3,62 & 2,92 \\
\hline
\end{tabular}

Como é possível observar, neste trabalho, a embalagem de poliestireno resultou em um melhor desempenho ambiental para oito das nove categorias de impacto analisadas, quando comparado às demais embalagens.

A exceção está na ecotoxicidade aquática, onde o poliestireno apresentou maior impacto em relação à embalagem de PLA. Segundo os autores, a quantidade de matéria-prima necessária para a produção de cada embalagem e as distâncias de transporte entre os locais de extração e manufatura foram as principais causas das diferenças dos desempenhos ambientais calculados.

O desenvolvimento de estudos sobre o perfil ambiental de plásticos pela PlasticEurope data desde 1993. O objetivo da instituição é compilar dados médios de desempenho ambiental da indústria europeia, a fim de estimular o melhoramento contínuo dos processos de manufatura e fornecer informações para a decisão de compra dos consumidores.

No relatório publicado em 2008, a PlasticEurope avaliou a carga ambiental do berçoao-portão da fábrica resultante da produção de 1,0kg GPPS e 1,0kg HIPS. As informações utilizadas para o ICV corresponderam à média dos fluxos elementares de entrada e saída da indústria europeia. Do mesmo modo, as características da produção de combustíveis e energia basearam-se em dados levantados pela International Energy Agency (IEA) para aquele mesmo ano e continente. 
Critérios mássicos de alocação foram adotados para todos os casos onde diferentes produtos eram manufaturados por uma mesma linha de produção. O resultado do perfil de desempenho ambiental obtido deste esforço está descrito na Tabela 14.

Tabela 14: Perfil de desempenho ambiental da produção de $1 \mathrm{~kg}$ de GPPS e $1 \mathrm{~kg}$ de HIPS (PlasticsEurope, 2008).

\begin{tabular}{lccc}
\hline \multicolumn{1}{c}{ Categoria de Impacto } & Unidade & GPPS & HIPS \\
\hline Mudanças climáticas & $\mathrm{kg} \mathrm{CO}_{2 \mathrm{eq}}$ & 3,46 & 3,46 \\
\hline Depleção da camada de ozônio & $\mathrm{g} \mathrm{CFC}-11$ & $\mathrm{n} / \mathrm{a}$ & $\mathrm{n} / \mathrm{a}$ \\
\hline Potencial de acidificação & $\mathrm{g} \mathrm{SO}_{2 \mathrm{eq}}$ & 11,09 & 11,82 \\
\hline Formação de ozônio troposférico & $\mathrm{g} \mathrm{eteno} \mathrm{eq}^{\text {equaca }}$ & 1,25 & 1,29 \\
\hline Eutrofizaça & $\mathrm{g} \mathrm{PO}_{4 \mathrm{eq}}$ & 0,72 & 0,76 \\
\hline Material particulado fino & $\mathrm{g} \mathrm{PM}_{10}$ & 0,90 & 0,97 \\
\hline Total de material particulado & $\mathrm{g}$ & 0,90 & 0,98 \\
\hline Geração de resíduo não perigoso & $\mathrm{kg}$ & 0,050 & 0,056 \\
\hline Geração de resíduo perigoso & $\mathrm{kg}$ & 0,029 & 0,028 \\
\hline
\end{tabular}

Para todas as categorias de impacto, a carga ambiental do GPPS e do HIPS apresentam valores absolutos similares, de forma que as diferenças verificadas entre os materiais ocorrem devido à incorporação da borracha de polibutadieno no processo de manufatura do HIPS.

De forma similar, a Divisão de Plástico do Conselho de Química Americano (ACC) publicou, em 2011, uma versão revisada do estudo sobre o desempenho ambiental de plásticos, dentre os quais estão o GPPS e o HIPS. O trabalho desenvolvido pela empresa Franklin Associates, fornece dados sobre os consumos de energia e matérias-primas, bem como sobre a emissão de poluentes resultantes da manufatura desses plásticos, desde a obtenção de recursos naturais até o "portão da fábrica". Este relatório atualiza uma versão preliminar apresentada em 2010 e um estudo prévio concluído em 2007 que analisou nove resinas e dois precursores de poliuretano, por meio do uso da metodologia apresentada pelas normas ABNT NBR ISO $14040 \mathrm{e}$ 14044 para desenvolvimento de inventários de ciclo de vida.

As etapas relativas à AICV não foram desenvolvidas pela ACC, de modo que os resultados se limitam a quantificação dos fluxos de entrada e saída dos processos elementares contemplados do berço ao portão da fábrica.

Ainda sobre as características de desempenho ambiental do poliestireno, Suwanmanee et. al. (2010) analisaram as emissões de gases efeito estufa nos ciclos de vida das bandejas de PLA e poliestireno produzidas na Tailândia. Para tanto, 
realizaram levantamento bibliográfico sobre o impacto ambiental ocasionado pela manufatura desses mesmos polímeros, desde a extração de suas matérias-primas. As quantidades de emissão de $\mathrm{CO}_{2}$ equivalente obtidas por estes pesquisadores e por outras fontes por eles citadas estão apresentadas na Tabela 15.

Tabela 15: Comparação entre a emissão de gases efeito estufa para os polímeros HIPS, GPPS e PLA - $\mathrm{kg} \mathrm{CO}$ eq $/ \mathrm{kg}$ de polímero (adaptado de SUWANMANEE, 2010).

\begin{tabular}{lccc}
\hline Resina & $\begin{array}{c}\text { SUWANMANEE et. al. } \\
(\mathbf{2 0 1 0 )}\end{array}$ & $\begin{array}{c}\text { SimaPro 7 } \\
\mathbf{( 2 0 0 8 )}\end{array}$ & $\begin{array}{c}\text { PlasticsEurope } \\
\mathbf{( 2 0 0 8 )}\end{array}$ \\
\hline HIPS & 3,76 & 2,92 & 3,46 \\
GPPS & 3,74 & 2,72 & 3,46 \\
PLA & 2,53 & - & - \\
\hline
\end{tabular}

A emissão de gases efeito estufa dos estudos variou em cerca de $30 \%$ do menor ao maior resultado. A maior contribuição foi calculada no estudo desenvolvido por Suwanmanee et. al. (2010).

Segundo os autores, este aumento da carga ambiental se deve a matriz energética tailandesa, a qual apresenta maior emissão de gases se comparado com as fontes de energia utilizadas nos demais trabalhos. 


\section{MÉTODO DE TRABALHO}

A estrutura metodológica da presente iniciativa foi organizada na forma das cinco etapas descritas a seguir:

I. Revisão Bibliográfica: levantamento junto a fontes de informação consistentes e referenciáveis de dados e informações que forneçam a base conceitual para a realização da análise de desempenho ambiental do poliestireno derivado de petróleo e daquele produzido parcialmente a partir de insumo renovável, tanto no que diz respeito à metodologia da ACV quanto ao processo de manufatura em si.

II. Avaliação do Ciclo de Vida: desenvolvimento das análises de desempenho ambiental do poliestireno derivado de fonte fóssil e do poliestireno originário de fonte parcialmente renovável. A estrutura desta etapa está baseada nas normas ABNT NBR ISO 14040:2009 e 14044:2009, próprias para a condução de estudos desta natureza. Nesse sentido, foram realizadas as seguintes atividades:

a. Caracterização do objeto em estudo: descrição dos processos em análise quanto às tecnologias empregadas, definição das coberturas temporais e geográficas, delimitação do sistema de produto; desenvolvimento dos critérios de exclusão e alocação, seleção do modelo de avaliação de impacto e fixação do fluxo de referência;

b. Elaboração de Inventários de ciclo de Vida (ICV): identificação e quantificação das correntes de matéria e de energia que entram e saem dos sistemas em análise, desde (ou para) outros sistemas antrópicos, ou mesmo, o meio ambiente;

c. Avaliação de Impactos Ambientais: identificação e estudo da magnitude dos efeitos ocorridos sobre o entorno e sobre o ser humano das atividades de transformação contempladas no estudo, por meio da determinação dos Perfis de Impactos Ambientais, como meio para o estabelecimento do desempenho ambiental dos poliestirenos em análise. 
III. Comparação Preliminar dos Resultados: análise do desempenho ambiental obtido para o poliestireno de origem fóssil e para aquele derivado parcialmente por fonte renovável, com o intuito de identificar oportunidade de aprimoramento do estudo.

IV. Refinamento do modelo: revisão dos fluxos de matéria e energia de cada processo elementar e levantamento de eventuais dados adicionais para a concepção de resultados mais apurados sobre o impacto ambiental de ambos os produtos em análise.

V. Análise crítica dos resultados: comparação do desempenho ambiental do poliestireno derivado de fonte fóssil com aquele de fonte parcialmente renovável. 


\section{ESTUDO DE ACV DO POLIESTIRENO}

\subsection{DefinIÇÃo DE OBJETIVO E ESCOPO}

\subsubsection{Definição de Objetivo}

O objetivo da presente iniciativa consiste em proceder a análises de desempenhos ambientais do poliestireno derivado de petróleo e do poliestireno manufaturado parcialmente por fonte renovável, a fim de avaliar a influência da proposição de mudança de insumo no saldo ambiental deste.

Nesse sentido, os resultados obtidos a respeito dos perfis de desempenho ambiental dos poliestirenos possibilitarão não somente identificar oportunidades de melhoria de processo, como também orientar o desenvolvimento de estratégias de negócio para o setor petroquímico. No que tange ao setor acadêmico, espera-se que este trabalho possa contribuir para a ampliação do banco de dados brasileiro de inventários de avaliação do ciclo de vida, apoiando o desenvolvimento de outros estudos relacionados à $\mathrm{ACV}$.

Sob o viés metodológico, esta apresentação segue as diretrizes sugeridas pelas normas ABNT NBR ISO 14040:2009 e 14044:2009, tendo como público alvo o setor petroquímico e sucroalcooleiro, visto à tecnologia de produção de eteno a partir de etanol de cana-de-açúcar.

\subsubsection{Definição de Escopo}

\subsubsection{Função}

Em trabalhos de ACV, a definição da função de um produto é necessária para que se possa determinar para qual exercício o objeto em estudo será avaliado. A análise sugerida pelo objetivo geral anteriormente proposto se restringe, em termos de aplicação da ACV, a uma abordagem do tipo "berço ao portão da fábrica"; que exclui aspectos ambientais das etapas de pós-produção e seus respectivos impactos. 
Além disso, tanto o GPPS como o HIPS classificam-se como bens de produção e não de consumo final. Por conta disso, as funções do estudo foram definidas como: produzir poliestireno GPPS; e produzir poliestireno HIPS.

\subsubsection{Unidade Funcional e Fluxo de Referência}

De acordo com a NBR ISO 14040 (2009), a Unidade Funcional (UF) é definida como o desempenho quantificado de um sistema de produto para o estabelecimento de uma unidade de referência em estudos de ACV. Portanto, estabeleceu-se como UF para os casos em análise: produzir $1.000 \mathrm{~kg}$ de poliestireno GPPS; e produzir $1.000 \mathrm{~kg}$ de poliestireno HIPS.

Portanto, o fluxo de referência para ambos os produtos é igual a $1000 \mathrm{~kg}$.

\subsubsection{Sistema de Produto}

\subsection{Poliestireno derivado exclusivamente de petróleo}

O sistema de produto do processamento de poliestireno aparece indicado, de maneira simplificada, na Figura 14. Por ser este um estudo de ACV, tanto o GPPS quanto o HIPS apresentam um conjunto específico de processos elementares. No entanto, identificou-se que estes conjuntos são praticamente equivalentes, diferindo, basicamente, na adição de polibutadieno (PBD) para a produção de HIPS.

Desta forma, em termos estruturais, o sistema de produto pode ser dividido em cinco subsistemas, a saber: extração de petróleo e gás natural; refino de petróleo para produção de nafta; produção de intermediários: eteno, benzeno (e, para aqueles que integram a família de poliestireno de alto impacto, o polibutadieno); produção de poliestireno; e transporte, o qual interliga os demais subsistemas apresentados.

O subsistema extração de petróleo engloba as atividades necessárias para a retirada do petróleo em ambiente marítimo e terrestre no território nacional e internacional, bem como o transporte e bombeamento deste até as refinarias. 


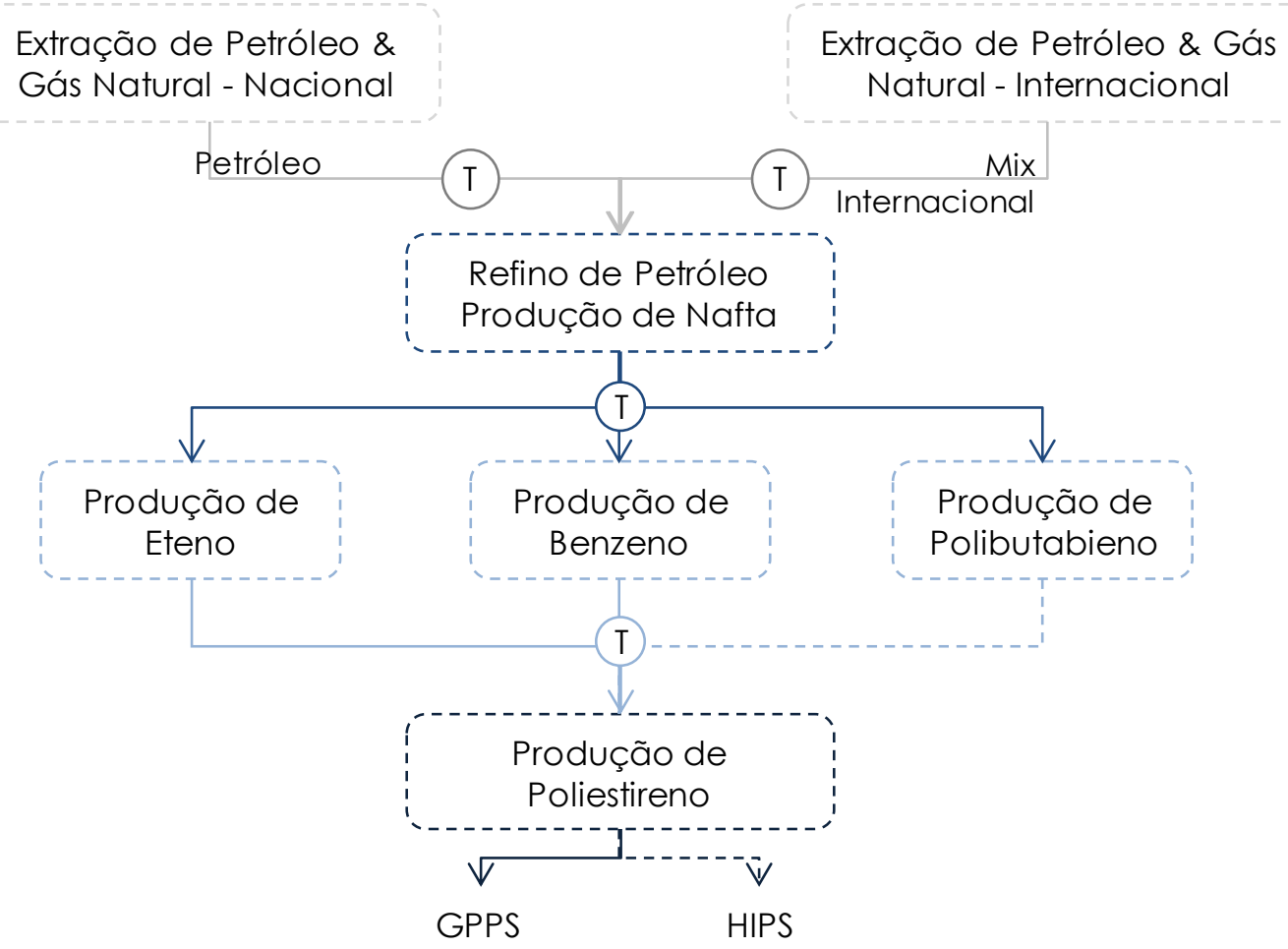

Figura 14: Fluxograma do sistema de produto do poliestireno derivado exclusivamente de petróleo.

O subsistema de refino de petróleo compreende todas as operações da refinaria para transformar petróleo cru em recursos energéticos e não energéticos, dentre eles a nafta.

A tecnologia de processamento de refino para produção de nafta é norteada naquela que, segundo a ANP, possui a maior flexibilidade e produtividade. Desta premissa, têm-se, então, as seguintes etapas: sistema de aquecimento e dessalinização do petróleo cru; destilação atmosférica; destilação a vácuo; coqueamento; e, hidrotratamento. A nafta segue, então, para a indústria de petroquímicos básicos.

Portanto, o subsistema de produção de intermediários visa, fundamentalmente, transformar nafta e gás natural em benzeno e eteno, enquanto que desses processos de transformação se obtém como subproduto o butadieno que, por polimerização, dá origem ao polibutadieno.

Por fim, o subsistema de produção de poliestireno pode ser estruturado na forma de três operações principais: transformação de benzeno e eteno em etilbenzeno; produção de estireno; e processamento do poliestireno.

Entre todas as etapas, é válido destacar as atividades de transporte que são responsáveis pelo envio das matérias-primas até as unidades de fabricação. 
Nesse contexto, convencionou-se que o escopo de aplicação da metodologia de ACV encerrasse-se quando o poliestireno, então na forma de pellets, estivesse em condições de ser distribuído aos devidos clientes.

\subsection{Poliestireno derivado parcialmente de fonte renovável}

O sistema de produto do processamento de poliestireno derivado parcialmente de fonte renovável aparece indicado na Figura 15. Como é possível observar, parte das etapas do sistema de produto apresentado na Figura 14 se repete para este cenário, havendo a modificação apenas dos subsistemas que antecedem à produção de eteno. Isto posto, as descrições dos subsistemas de extração do petróleo e gás natural, refino de petróleo para produção de nafta e produção de benzeno e polibutadieno se mantêm, assim como as etapas de transporte entre os mesmos.

A despeito do subsistema de cultivo de cana-de-açúcar, este engloba as atividades agrícolas elencadas a seguir: preparação do solo; plantio; aplicação de corretivos agrícolas; colheita; e destinação dos resíduos produzidos por estas etapas.

Em seguida, a cana picada resultante da colheita é encaminhada para o subsistema de produção de etanol, cujo objetivo é produzir etanol hidratado com $5 \%$ em massa de água.

Desta forma, o último subsistema introduzido ao sistema de produto da Figura 15 compreende na produção de eteno por meio de desidratação de etanol em presença de água.

Observa-se também que entre os novos subsistemas elencados, há uma etapa de transporte responsável pelo envio da matéria-prima às industriais.

Uma vez que as matérias-primas para a produção de poliestireno são as mesmas, independentemente da origem que estas possuem, o subsistema de produção de poliestireno se repete em comparação àquele descrito anteriormente. 


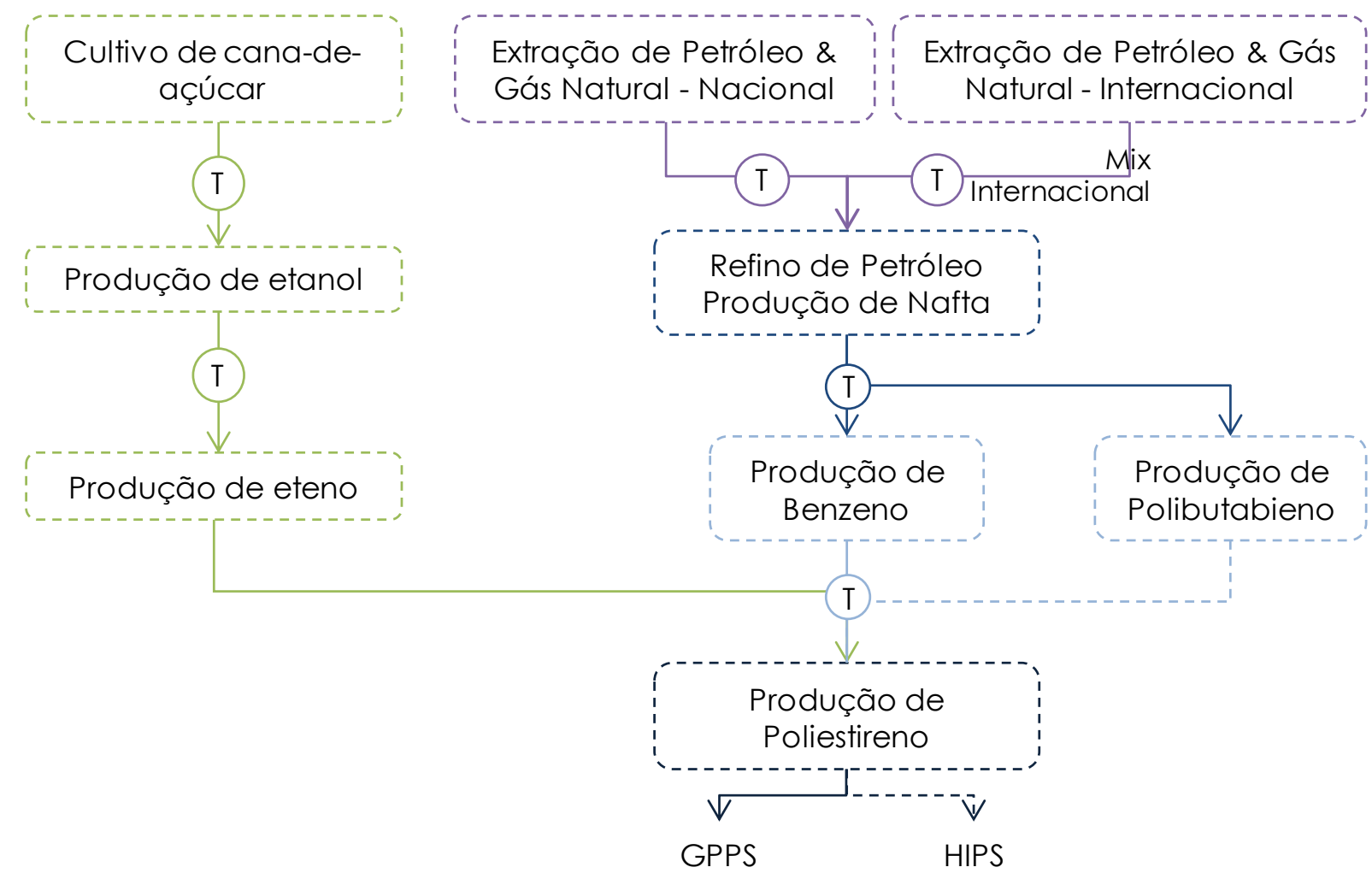

Figura 15: Fluxograma do sistema de produto do poliestireno derivado parcialmente de fonte renovável

\subsubsection{Fronteiras do sistema de produto}

Como já referido, a definição do sistema de produto para deste estudo baseou-se no enfoque metodológico do tipo 'berço ao portão da fábrica'. Assim sendo, para ambos os casos este engloba, essencialmente, todas as etapas do ciclo de vida da fabricação do GPPS e do HIPS, desde a extração de recursos naturais até a produção final dos mesmos.

A definição das fronteiras do sistema está fundamentada, em igual importância, nas seguintes premissas:

- Desconsideração de determinados aspectos ambientais - fundamentada por meio da aplicação de critérios de exclusão que avaliam a contribuição relativa do aspecto ambiental em relação à massa, energia e relevância ambiental. Tais premissas serão apresentadas em detalhe mais adiante no texto, para cada subsistema que constitui os sistemas de produto em análise; 
- Desconsideração de aspectos ambientais associados a produção de bens de capital e de utilização de mão de obra;

- Os aspectos ambientais da fabricação das mais diversas embalagens de produtos intermediários também não foram considerados;

- Dada à falta de informação quanto aos insumos adicionais empregados nos subsistemas de extração de petróleo, cultivo de cana-de-açúcar, produção de eteno a partir de etanol e produção de poliestireno, adotou-se que tais materiais são recursos advindos do meio ambiente, entrando no sistema com carga ambiental nula.

- Na etapa de transporte, contabilizaram-se apenas as emissões atmosféricas ocorridas da queima do combustível durante o deslocamento dos caminhões e transporte marítimos. Os aspectos ambientais decorrentes da construção de pavimentos de rodagem, fabricação dos veículos (caminhões ou navios), bem como de seu uso não foram considerados;

- A geração de energia elétrica foi caracterizada por banco de dados internacional e adaptada para as condições brasileiras de acordo com o grid energético disponibilizado no Balanço Energético Nacional (BEN) para o ano de 2011. Tal condicionante introduz imprecisões. No entanto, a ausência de bancos de dados nacionais para tal modelagem configura esta alternativa como mais adequada do que a simples exclusão desse aspecto ambiental tão relevante.

- A caracterização dos efluentes líquidos considerou parâmetros tais como: demanda bioquímica de oxigênio $\left(\mathrm{DBO}_{5}\right)$; demanda química de oxigênio (DQO); sólidos suspensos totais (SST), e teores de Fósforo e nitrogênio.

- Supôs-se para efeito de modelagem que os caminhões empregados em transportes rodoviários retornam vazios aos seus pontos de origem;

- Para os transportes de Petróleo Nacional e Importado, tomou-se por premissa adotar $100 \mathrm{~km}$ de distância terrestre até o porto de origem (porto da capital do petróleo importado) para depois ser calculada a distância até os portos de destino. Esta distância percorrida é tida como usual para banco de dados. 
Quanto ao modal de transporte, este considerou veículos com capacidade de carga superior a 28t, cujos aspectos ambientais decorrentes de seu uso foram modelados a partir de um banco de dados internacional.

- A partir do refino, considera-se que todos os produtos petroquímicos são transportados por tubovias até as etapas subsequentes de produção.

- O cultivo de cana-de-açúcar foi restrito aos estados de São Paulo e Paraná e as distâncias médias de transporte rodoviário e ferroviário foram adotadas para a contabilização dos aspectos ambientais decorrentes desta atividade.

\subsubsection{Cobertura tecnológica}

Conforme abordado antes, a manufatura de poliestireno em território nacional encontra-se centralizada em quatro empresas: Dow Brasil, Innova S.A., Videolar e UNIGEL.

Assim, para representar as características tecnológicas de produção de poliestireno, definiu-se por uma rota tecnológica média capaz de representar a contento o setor brasileiro de produção de poliestireno. Esta compreendeu: produção de etilbenzeno a partir de alquilação de benzeno com eteno; manufatura de monômero de estireno por meio de desidrogenação catalítica do etilbenzeno em presença de vapor d'água; e, polimerização de estireno a partir de reatores contínuos agitados.

No caso da produção de petróleo nacional, a tecnologia considerada é a de extração offshore em plataforma. Para os países importadores de petróleo, foram respeitadas, sempre que possível, as características e particularidades locais.

Para o refino de petróleo e produção de nafta, o craqueamento a vapor foi definido como a tecnologia mais expressiva. Na produção de eteno e benzeno, adotou-se respectivamente o craqueamento a vapor e a reforma catalítica como tecnologias, no intuito de representar as atividades empregadas na maior parte das empresas do setor em território nacional. Vale ressaltar que essas tecnologias estão alinhadas a prática convencional do mercado, tal como apresentado na revisão bibliográfica.

O cultivo de cana-de-açúcar e produção de etanol adotaram características típicas das plantações e usinas brasileiras. 
Já a transformação de etanol em eteno foi balizada nos resultados obtidos por um grupo de pesquisadores da Universidade da Pensilvânia, por meio da simulação de uma planta de produção de eteno a partir da desidratação catalítica de etanol. Esta transformação ocorre em reatores adiabáticos de leito fixo, conforme processamento praticado e patenteado por indústrias nacionais.

\subsubsection{Cobertura temporal}

No que se refere à cobertura temporal, foram utilizados dados que refletem a situação do período compreendido entre 2009 e 2010 sempre que o enfoque da análise se tratava das rotas petroquímicas. A geração de energia baseou-se no grid brasileiro de 2011, visto a disponibilidade de dados. Tal decisão foi tomada com o objetivo de aproveitar dados de processos elementares da literatura especializada.

No que tange ao cultivo de cana-de-açúcar, esta cobertura foi expendida para o período de 2008 a 2011, conforme estudo desenvolvido por Sugawara (2012). intuito de tamanha abrangência foi amenizar a distorção dos dados de produtividade do setor, devido a condições climáticas não usuais, como longos períodos de seca.

\subsubsection{Cobertura Geográfica}

A fim de manter a consistência do estudo, considerou-se que os dados deveriam reportar a realidade dos processos elementares no local em estes se desenvolviam. Logo, a cobertura geográfica engloba os países produtores de petróleo das regiões que fornecem esta matéria-prima para o Brasil, e produtores de nafta da Refinaria Alberto Pasqualini (REFAP) e Refinaria Henrique Lage (REVAP).

Estas refinarias foram selecionadas por estarem localizadas, respectivamente, nos estados de Rio Grande do Sul e São Paulo, próximas às principais unidades produtoras de poliestireno. Além disso, o cultivo e processamento da cana-de-açúcar compreenderam o estado de São Paulo e Paraná, visto a importância destes locais para o setor sucroalcooleiro brasileiro. 
Quaisquer outras variações de ordem geográfica foram introduzidas por conta de bancos de dados empregados, tal como no caso da Cobertura Tecnológica, para complementar o modelo dentro dos contornos em que este está estabelecido.

\subsubsection{Requisitos de qualidade dos dados}

A qualidade dos dados incorporados neste estudo é fundamentada em duas diretrizes. A primeira preconiza que a ACV do poliestireno deve refletir a realidade dos sistemas produtivos das indústrias em operação. A segunda diretriz, estabelece que os insumos consumidos por esta manufatura devam possuir representatividade no cenário nacional.

Dessa forma, definiu-se pela utilização de dados secundários, os quais foram agrupados em duas categoriais: dados extraídos diretamente da literatura e dados modelados a partir de informações obtidas em estudos técnicos do setor. No primeiro grupo enquadram-se os processos elementares de: extração de petróleo; refino de petróleo; cultivo de cana-de-açúcar; produção de eteno, benzeno e polibutadieno de fonte fóssil; produção de etanol; e, produção de poliestireno.

Dados secundários modelados para fechamento de balanço mássico e energético foram utilizados também para composição do inventário do subsistema de produção de eteno a partir de etanol.

As fontes de informação para coleta dos dados secundários são procedentes de artigos científicos, livros técnicos reconhecidos pelos setores em questão, trabalhos de mestrado e doutorado, bem como de patentes nacionais. O detalhamento da origem dos dados será descrita mais adiante, nos inventários do ciclo de vida dos produtos.

\subsubsection{Fonte dos dados}

O estudo foi desenvolvido essencialmente a partir de dados secundários recolhidos junto a literatura científica adequada, conforme a representativa da condição brasileira de processamento dos referidos polímeros. 
Rotinas de validação e tratamento desses dados foram aplicadas no sentido de fazer com que estes fossem capazes de espelhar, de maneira adequada e suficiente, a realidade que se busca modelar em termos de geração de cargas ambientais.

\subsubsection{Procedimentos de alocação}

Neste estudo, a técnica de alocação foi aplicada sempre que em determinado processo elementar ocorresse à geração de mais de um produto, como é o caso do sistema de refino ou até mesmo da produção de etanol em usinas com destilarias anexas.

A alocação ocorreu, fundamentalmente, para a partição de aspectos ambientais onde uma mesma rota tecnológica é responsável por manufaturar mais de um produto. Nesse sentido, tem-se a segregação dos fluxos de entrada e saída da refinaria para a produção de nafta, no qual adotou-se o critério energético de repartição. Já para a produção de etanol, o critério econômico foi aplicado para o distribuição, entre etanol e açúcar, de aspectos a eles pregressos.

\subsubsection{Exclusão de aspectos ambientais}

A decisão acerca da exclusão de aspectos ambientais seguiu critérios de três naturezas: contribuição cumulativa em termos mássicos e energéticos em relação ao total de entradas ou saídas do processo elementar; relevância ambiental; e relevância processual.

O primeiro critério considera excluir certo aspecto ambiental - ou seja, certo fluxo de matéria ou energia - cuja contribuição cumulativa seja inferior a $1 \%$ do total de entradas ou saídas a que esta quantidade se associa em determinado processo elementar.

Ressalta-se como exceção a esta premissa, as condições adotadas para exclusão de processos de extração e importação de petróleo, de modo que para tais circunstâncias adotou-se por premissa, a inclusão de processos e países cuja representatividade acumulada perfizesse ao menos $90 \%$ do volume de petróleo importado pelo país. 
Vale salientar que a simples contribuição percentual do aspecto ambiental não é suficiente para excluí-lo do sistema de produto, sendo necessária uma análise de relevância ambiental. Dessa forma, verificou-se se os aspectos ambientais excluídos, em virtude de suas contribuições cumulativas, não possuíam potencial de impacto ambiental significante.

Atendendo a estes dois critérios, o aspecto ambiental foi desconsiderado do ciclo de vida do produto. Demais especificidades sobre as exclusões realizadas serão descritas adiante para cada processo elementar constante nos sistemas de produto.

\subsubsection{Método de Avaliação de Impacto e categorias de impacto}

O método de avaliação aplicado para cumprir a etapa de Avaliação de Impactos Ambientais deste estudo foi o $\operatorname{ReCiPe}(H)$ - Midpoint, versão 1.07. Nesta opção, dezoito categorias de impacto ambiental são medidas a partir de padrões físicos estabelecidos cientificamente, evitando desvios de interpretação por subjetividades decorrentes das etapas opcionais da AICV.

Neste contexto e, dado o caráter da análise, foram selecionadas as treze categorias de impacto descritas a seguir: Mudanças Climáticas (CC); Depleção da Camada de Ozônio (DCO); Toxicidade Humana (TH); Formação de Oxidantes Fotoquímicos (OF); Formação de Material Particulado (MP); Acidificação Terrestre (AT); Eutrofização em Água Doce (EU); Ecotoxicidade terrestre (ET); Ecotoxicidade em Água Doce (EA); Ocupação do Solo Agricultável (OSA); Transformação de Áreas Naturais (NA); Depleção de Água (DA); e, Depleção de Recurso Fóssil (DF).

Assim, a exclusão das demais categorias foi fundamentada nas características do sistema de produto em análise e nos fluxos de matéria e energia que o compõem. Desta forma, a radiação ionizante foi retirada do escopo da pesquisa, uma vez que a contribuição de fontes de energia nuclear na matriz energética nacional é diminuta. Além disso, eutrofização e ecotoxicidade marinhas não foram contabilizadas na análise. Por fim, a ocupação de solo urbano e depleção de metal apresentaram baixas contribuições, em termos de significância ambiental, para o perfil de desempenho dos poliestirenos, justificando a sua supressão no estudo.

Ainda e de forma adicional, optou-se por realizar a comparação entre os poliestirenos também por meio do método $\operatorname{ReCiPe}(H)$ - Endpoint versão 1.07. Esta decisão foi 
tomada, a fim de averiguar as distorções associadas ao uso de mecanismos de cálculo de ponderação e agrupamento no perfil de desempenho do poliestireno fóssil e parcialmente renovável.

\subsubsection{Tipo de Revisão Crítica}

Devido ao caráter de análise comparativa entre os poliestirenos abarcados no presente estudo, decidiu-se que a revisão crítica seria realizada com o viés de identificar os aspectos ambientais responsáveis pelas diferenças nos perfis de desempenho ambiental dos produtos analisados.

Portanto, o intuito da revisão crítica é subsidiar o desenvolvimento de estratégias de melhoria contínua dos processos englobados nos sistemas de produto do poliestireno, a partir dos resultados desta avaliação.

É válido ressaltar, assim, que esta análise exclui possíveis juízos de valor, de modo que tal revisão não apresenta qualquer posicionamento quanto à preferência ambiental dos poliestirenos.

\subsection{INVENTÁRIO DO CICLO DE VIDA}

\subsubsection{Subsistema de extração de petróleo}

O ciclo de vida do poliestireno se inicia na fase de extração de petróleo. Neste sentido, estão descritas a seguir as características de escopo relacionadas a este subsistema, de forma a constituir o seu Inventário do Ciclo de Vida.

a. Fonte de dados: Todos os dados correspondem a fontes secundárias de informação;

b. Cobertura Temporal: os dados referentes à origem de petróleo nacional e à representatividade do petróleo importado foram coletados com base no ano de 2009 a 2010. As exceções ocorrem quando adotados os bancos de dados para extração de petróleo.

c. Cobertura Geográfica: visto que este subsistema compreende também a extração de petróleo internacional, a cobertura geográfica de extração é 
composta pelo Estado do Rio de Janeiro, além dos principais países importadores listados na Tabela 18.

d. Critérios de Exclusão: contribuição mássica cumulativa de $90 \%$ de todo o recurso ofertado, tanto para a definição de origem quanto para a procedência do petróleo.

e. Cobertura Tecnológica: extração em plataformas offshore no Brasil e onshore para o petróleo importado.

\subsubsection{Origem e procedência do petróleo}

Para o desenvolvimento do inventário do subsistema de extração de petróleo, foram identificados quais os locais de origem do recurso consumido no Brasil - volume processado nacionalmente e importado -, bem como a procedência do recurso extração onshore ou offshore.

Assim, no que tange a oferta de petróleo nacional, foi considerada apenas a produção offshore que corresponde a $91 \%$ da produção do petróleo nacional, cujo percentual foi determinado a partir dos dados coletados na cobertura temporal do estudo, os quais aparecem indicados na Tabela 16. Desta forma, assumiu-se para fins desta modelagem que o petróleo nacional distribuído nas Refinarias origina-se exclusivamente de extração offshore.

Tabela 16: Exploração de Petróleo Nacional (baseado em ANP, 2011).

\begin{tabular}{ccccc}
\hline $\begin{array}{c}\text { ORIGEM } \\
\text { País/Região }\end{array}$ & $\begin{array}{c}\mathbf{2 0 0 9} \\
\text { mil barris/ano }\end{array}$ & $\begin{array}{c}\mathbf{2 0 1 0} \\
\text { mil barris/ano }\end{array}$ & $\begin{array}{c}\text { Valores médios } \\
\text { entre 2009 e 2010 }\end{array}$ & $\begin{array}{c}\text { \% de } \\
\text { Contribuição }\end{array}$ \\
\hline Brasil Offshore & 646.418 & 683.981 & 665200 & $91,0 \%$ \\
\hline Brasil Onshore & 65.465 & 65.973 & 65719 & $9,0 \%$ \\
\hline TOTAL & 711.883 & 749.954 & 730918 & \\
\hline
\end{tabular}

A respeito dos estados de origem do petróleo nacional, foi identificado que entre os anos de 2009 e 2010, cerca de $90 \%$ do petróleo produzido em mar nacionalmente foi originado da Unidade Federativa do Rio de Janeiro, tal como mostra a Tabela 17. 
Tabela 17: Produção de petróleo, por localização em mar, segundo Unidades da Federação 2009-2010 (baseado em ANP, 2011).

\begin{tabular}{lcccc}
\hline $\begin{array}{c}\text { ORIGEM } \\
\text { Unidades de Federação }\end{array}$ & $\begin{array}{c}\mathbf{2 0 0 9} \\
\text { mil barris/ano }\end{array}$ & $\begin{array}{c}\mathbf{2 0 1 0} \\
\text { mil barris/ano }\end{array}$ & $\begin{array}{c}\text { Valores médios } \\
\text { entre 2009 e 2010 }\end{array}$ & $\begin{array}{c}\text { \% de } \\
\text { Contribuição }\end{array}$ \\
\hline Rio de Janeiro & 605.213 & 594.804 & 600.008 & $90,20 \%$ \\
\hline Espírito Santo & 31.371 & 75.232 & 53.302 & $8,01 \%$ \\
São Paulo & 333 & 5.278 & 2.806 & $0,42 \%$ \\
Sergipe & 3.515 & 3.063 & 3.289 & $0,49 \%$ \\
\hline Rio Grande do Norte & 3.012 & 2.914 & 2.963 & $0,45 \%$ \\
Ceará & 2.539 & 2.261 & 2.400 & $0,36 \%$ \\
Bahia & 338 & 343 & 341 & $0,05 \%$ \\
Alagoas & 96 & 85 & 91 & $0,01 \%$ \\
\hline TOTAL & 646.418 & 683.981 & 665.200 & $100 \%$ \\
\hline
\end{tabular}

Nesse sentido, para o desenvolvimento do inventário deste subsistema, apenas o estado do Rio de Janeiro foi incorporado como fornecedor de petróleo nacional para as refinarias.

No que tange a origem, para complementar seu suprimento em 2010, o Brasil importou 124 milhões de barris de petróleo, dos quais aproximadamente 347 mil barris foram processados diariamente nas refinarias brasileiras.

Desta forma, para a modelagem do processo elementar de importação de petróleo, utilizou-se mais uma vez o critério de exclusão mássica cumulativa. A Tabela 18 traz os resultados desse processo, destacando os principais fornecedores de petróleo estrangeiro para o Brasil em 2009 e 2010. Juntos, Nigéria, Arábia Saudita, Líbia, Iraque e Argélia representaram mais de $92 \%$ deste total.

Tabela 18: Volume de carga processada importada, segundo país de origem - Média 2009 e 2010 (ANP, 2011)

\begin{tabular}{lccccc}
\hline $\begin{array}{c}\text { Origem } \\
\text { Países/Região }\end{array}$ & $\begin{array}{c}\text { Média 2009 } \\
\text { e 2010 } \\
\text { Barris/dia }\end{array}$ & $\begin{array}{c}\text { \% de } \\
\text { contribuição }\end{array}$ & $\begin{array}{c}\text { \% Acumulado } \\
\text { de } \\
\text { contribuição }\end{array}$ & $\begin{array}{c}\% \\
\text { Contribuição } \\
\text { Normatizada }\end{array}$ & $\begin{array}{c}\text { \% Acumulado de } \\
\text { contribuição } \\
\text { Normatizada }\end{array}$ \\
\hline Nigéria & 205.460 & $53,01 \%$ & $53,01 \%$ & $57,45 \%$ & $57,45 \%$ \\
\hline Arábia Saudita & 63.488 & $16,38 \%$ & $69,39 \%$ & $17,75 \%$ & $75,20 \%$ \\
\hline Líbia & 36.576 & $9,44 \%$ & $78,83 \%$ & $10,23 \%$ & $85,43 \%$ \\
\hline Iraque & 31.104 & $8,03 \%$ & $86,86 \%$ & $8,70 \%$ & $94,13 \%$ \\
\hline Argélia & 21.003 & $5,42 \%$ & $92,27 \%$ & $5,87 \%$ & $100,00 \%$ \\
\hline Argentina & 8.357 & $2,16 \%$ & $94,43 \%$ & - & - \\
\hline Reino Unido & 8.065 & $2,08 \%$ & $96,51 \%$ & - & - \\
\hline Austrália & 4.498 & $1,16 \%$ & $97,67 \%$ & - & - \\
\hline Angola & 4.457 & $1,15 \%$ & $98,82 \%$ & - & - \\
\hline Guiné Equatorial & 3.816 & $0,98 \%$ & $99,81 \%$ & - & - \\
\hline Venezuela & 748 & $0,19 \%$ & $100,00 \%$ & - & - \\
\hline \multicolumn{1}{c}{ Total } & $\mathbf{3 8 7 . 5 7 2}$ & $\mathbf{1 0 0} \%$ & --- & $\mathbf{1 0 0} \%$ & -- \\
\hline
\end{tabular}




\subsubsection{Transporte do Petróleo Bruto}

Após a extração, os petróleos de origem nacional e internacional são encaminhados à unidade de refino. A operação de terminais e oleodutos é um elo importante na logística de abastecimento do Sistema Petrobrás e, portanto, da REFAP e REVAP. Deste modo, dos campos de extração, o petróleo é transportado por oleodutos e ou por navios para os terminais petroquímicos, para então ser recebido no Terminal Marítimo Almirantes Soares Dutra (TEDUT) e no Terminal Marítimo Almirante Barroso (TEBAR), que compreendem os trechos responsáveis por reencaminhar o recurso às refinarias, respectivamente

De acordo com dados da Transpetro (2010), as instalações do TEDUT encontram-se localizadas no município de Tramandaí e Osório, de modo que as transferências de matéria são realizadas pelo oleoduto Osório-Canoas (Oscan), de 98km de extensão. Já o oleoduto OSVAT, proveniente do terminal TEBAR, é constituído por um trecho inicial até a cidade de Guararema, cuja distância perfaz $83 \mathrm{~km}$, além do trecho secundário responsável por encaminhar o petróleo até a cidade de São José dos Campos, o qual possui $35 \mathrm{~km}$. Nenhuma perda de material no transporte realizado a partir de oleodutos foi considerada para o estudo.

Ressalta-se que o petróleo oriundo dos campos de extração do estado do Rio de Janeiro é, assim, encaminhado ao TEDUT por meio de transporte marítimo, já que a infraestrutura de oleodutos existente não integra este estado ao Rio Grande do Sul. A distância percorrida entre o Porto do Rio de Janeiro e o TEDUT foi estimada em 1684 $\mathrm{km}$.

Para o transporte de petróleo internacional, foram calculadas as distâncias médias entre os principais terminais existentes nos países apresentados na Tabela 18, em termos de movimentação de carga, até respectivamente os Portos de Osório e Santos, via deslocamento marítimo. Estas distâncias estão descritas na Tabela 19. 
Tabela 19: Distâncias de transporte marítimo do petróleo importado ${ }^{6}$

\begin{tabular}{lccc}
\hline \multicolumn{1}{c}{ País de Origem } & Porto de Origem & Portos de Chegada & Distância Percorrida \\
\hline Nigéria & Lagos & Osório/Santos & $7.549 \mathrm{~km}$ \\
\hline Arábia Saudita & Riyadh & Osório/Santos & $14.192 \mathrm{~km}$ \\
\hline Líbia & Sidra & Osório $/$ Santos & $11.984 \mathrm{~km}$ \\
\hline Iraque & Umm Qasr & Osório $/$ Santos & $16.331 \mathrm{~km}$ \\
\hline Argélia & Porto Arzew (Oran) & Osório/Santos & $9.765 \mathrm{~km}$ \\
\hline
\end{tabular}

\subsubsection{Emissões para atmosfera}

As emissões atmosféricas compreendidas neste subsistema dizem respeito àquelas geradas por perdas no sistema de extração e no condicionamento de produtos necessários para o processo de extração, bem como pela queima de combustível no transporte marítimo e nas plataformas para geração de energia. Vale ressaltar que a quantificação dos poluentes atmosféricos foi baseada em informações contidas em bancos de dados.

\subsubsection{Emissões para o solo}

O processo de extração de petróleo resulta na geração de efluentes líquidos que são posteriormente encaminhados para tratamento. O lodo biológico produzido na estação de tratamento, assim como borras oleosas procedentes da manutenção dos equipamentos são descartados como resíduos sólidos, compondo as principais contribuições de emissão de poluentes para o solo.

\subsubsection{Emissões para a água}

A geração de efluente aquoso na extração de petróleo somada às perdas desde recurso no transporte transoceânico são os aspectos que aportam em emissões diretas de poluentes para a água.

\footnotetext{
${ }^{6}$ Valores calculados a partir do site: www.searates.com/reference/portdistance
} 
Segundo VIANNA (2006), a perda de óleo cru no transporte transoceânico é estimada em $8,30 \%$. Isto posto, a quantidade do recurso transportada para este estudo foi calculada a partir da média aritmética entre total de material que deixa o porto de origem e aquele que chega ao porto de destino, gerando um emissão de $0,083 \mathrm{~kg}$ de óleo cru por quilo de petróleo transportado.

As características dos demais efluente lançados na água foram mantidas de acordo com os bancos de dados listados na Tabela 20.

\subsubsection{Banco de Dados}

Devido à indisponibilidade de um inventário próprio para retratar o desempenho ambiental da extração de petróleo no Brasil, foi adotado como referência a extração de petróleo offshore na Noruega, uma vez que esta apresenta semelhança tecnológica às características de extração nacionais. As informações contidas no inventário, portanto, se basearam no banco de dados USLCI (NREL, 2011). Levantamentos junto a bibliografias especializadas foram efetuados no sentido de coletar dados complementares que permitissem a customização deste modelo à condição de extração de petróleo que ocorre no Brasil. De posse de tais informações, os dados do ICV original foram adaptados para as características nacionais.

Com relação ao petróleo importando, a partir do uso da Base de Dados do Ecoinvent, foram identificados os bancos de dados que melhor se assemelhavam aos países contemplados por este estudo. Desta forma, a tecnologia de extração onshore da Nigéria foi escolhida para representar a extração neste país, enquanto que a extração onshore do Oriente Médio foi adotada para a Arábia Saudita, Líbia e Iraque, e a tecnologia onshore da África foi utilizada para a Argélia, conforme mostra a Tabela 20.

Tabela 20: Bancos de dados utilizados para representar extração de petróleo importado

\begin{tabular}{cc} 
Origem & Banco de Dados - Ecoinvent \\
\hline Brasil & crude oil, at production offshore/NO U \\
Nigéria & Crude oil, at production/NG U \\
Arábia Saudita | Líbia | Iraque & Crude oil, at production onshore/RME U \\
\hline Argélia & Crude oil, at production onshore/RAF U \\
\hline
\end{tabular}


Para os transportes transoceânico e via oleodutos, foram empregados os bancos de dados indicados na Tabela 21.

Tabela 21: Banco de dados adotados para os sistemas de transporte de petróleo cru

\begin{tabular}{cc} 
Sistema de Transporte & Banco de Dados \\
\hline Transoceânico & Transport, transoceanic tanker/OCE U \\
Oleoduto & Transport, by pipeline, onshore/ OCE U \\
\hline
\end{tabular}

\subsubsection{Inventário Consolidado da extração de petróleo nacional}

A Tabela 22 apresenta o inventário consolidado de aspectos ambientais da extração offshore de petróleo de origem nacional.

Tabela 22: Inventário da extração de $1 \mathrm{~kg}$ petróleo nacional - offshore

\begin{tabular}{lcc}
\hline Entradas/saídas & Unidade & Quantidade \\
\hline Entradas & & \\
Oil, crude, in ground & $\mathrm{kg}$ & 1.000063 \\
Gas, natural, in ground & $\mathrm{m}^{3}$ & $3.42 \mathrm{E}-05$ \\
Water, salt, sole & $\mathrm{m}^{3}$ & 0.000694 \\
Water, salt, ocean & $\mathrm{m}^{3}$ & 0.001357 \\
Platform, crude oil, offshore/OCE/I U & $\mathrm{p}$ & $5.1095 \mathrm{E}-11$ \\
Diesel, at regional storage/RER U & $\mathrm{kg}$ & 0.00017102 \\
Chemicals organic, at plant/GLO U & $\mathrm{kg}$ & 0.00016501 \\
Chemicals inorganic, at plant/GLO U & $\mathrm{kg}$ & 0.00021873 \\
Sweet gas, burned in gas turbine, production/m³/NO U & $\mathrm{m}$ & 0.015452 \\
Natural gas, sweet, burned in production flare/m/GLO U & $\mathrm{m}^{3}$ & 0.0034133 \\
Diesel, burned in diesel-electric generating set/GLO U & $\mathrm{MJ}$ & 0.057067 \\
Well for exploration and production, offshore/OCE/I U & $\mathrm{m}$ & $2.5961 \mathrm{E}-06$ \\
Residual fuel oil, combusted in industrial boiler/US & $\mathrm{kg}$ & 0,00084538902 \\
Process-specific burdens, sanitary landfill/CH U & $\mathrm{kg}$ & 0,0261 \\
Emissões para o Ar & & \\
Ethane & $\mathrm{kg}$ & $2.49 \mathrm{E}-05$ \\
Propane & $\mathrm{kg}$ & $1.32 \mathrm{E}-05$ \\
Butane & $\mathrm{kg}$ & $6.87 \mathrm{E}-06$ \\
Carbon dioxide, fóssil & $\mathrm{kg}$ & 0.000935 \\
Nitrogen oxides & $\mathrm{kg}$ & $1.24 \mathrm{E}-06$ \\
Mercury & $\mathrm{kg}$ & $1.55 \mathrm{E}-11$ \\
Radon-222 & $\mathrm{kBq}$ & $3.1 \mathrm{E}-05$ \\
\hline
\end{tabular}




\begin{tabular}{|c|c|c|}
\hline Entradas/saídas & Unidade & Quantidade \\
\hline Methane, bromochlorodifluoro-, Halon 1211 & $\mathrm{~kg}$ & 7.3E-10 \\
\hline Heat, waste & MJ & 0.011932 \\
\hline Methane, fóssil & $\mathrm{kg}$ & 0.000197 \\
\hline $\begin{array}{l}\text { NMVOC, non-methane volatile organic compounds, } \\
\text { unspecified origin }\end{array}$ & $\mathrm{kg}$ & 0.001297 \\
\hline \multicolumn{3}{|l|}{ Emissões para a Água } \\
\hline Carboxylic acids, unspecified & $\mathrm{kg}$ & 0.000176 \\
\hline $\mathrm{PAH}$, polycyclic aromatic hydrocarbons & $\mathrm{kg}$ & $2.8 \mathrm{E}-07$ \\
\hline Phenol & $\mathrm{kg}$ & 4.01E-06 \\
\hline Benzene & $\mathrm{kg}$ & 2.11E-06 \\
\hline Toluene & $\mathrm{kg}$ & $2.11 \mathrm{E}-06$ \\
\hline Xylene & $\mathrm{kg}$ & $2.11 \mathrm{E}-06$ \\
\hline Oils, unspecified & $\mathrm{kg}$ & $2 \mathrm{E}-05$ \\
\hline Arsenic, ion & $\mathrm{kg}$ & 7.14E-09 \\
\hline Lead & $\mathrm{kg}$ & $3.41 \mathrm{E}-09$ \\
\hline Cadmium, ion & $\mathrm{kg}$ & $8.75 E-10$ \\
\hline Copper, ion & $\mathrm{kg}$ & 2.73E-09 \\
\hline Chromium, ion & $\mathrm{kg}$ & 3.23E-09 \\
\hline Mercury & $\mathrm{kg}$ & $3.12 \mathrm{E}-11$ \\
\hline Nickel, ion & $\mathrm{kg}$ & $4.85 \mathrm{E}-09$ \\
\hline Zinc, ion & $\mathrm{kg}$ & $9.34 \mathrm{E}-08$ \\
\hline BOD5, Biological Oxygen Demand & $\mathrm{kg}$ & 0.000272 \\
\hline COD, Chemical Oxygen Demand & $\mathrm{kg}$ & 0.000272 \\
\hline DOC, Dissolved Organic Carbon & $\mathrm{kg}$ & $9.68 \mathrm{E}-05$ \\
\hline TOC, Total Organic Carbon & $\mathrm{kg}$ & $9.68 \mathrm{E}-05$ \\
\hline AOX, Adsorbable Organic Halogen as $\mathrm{Cl}$ & $\mathrm{kg}$ & $2.06 \mathrm{E}-10$ \\
\hline Nitrogen & $\mathrm{kg}$ & $1.54 \mathrm{E}-08$ \\
\hline Sulfur & $\mathrm{kg}$ & $5.35 \mathrm{E}-08$ \\
\hline \multicolumn{3}{|l|}{ Resíduos Sólidos para tratamento } \\
\hline & $\mathrm{m}^{3}$ & $1.9956 \mathrm{E}-07$ \\
\hline $\begin{array}{l}\text { Disposal, municipal solid waste, } 22.9 \% \text { water, to sanitary } \\
\text { landfill/CH U }\end{array}$ & $\mathrm{kg}$ & 3.7606E-05 \\
\hline $\begin{array}{l}\text { Disposal, wood untreated, } 20 \% \text { water, to municipal } \\
\text { incineration } / \mathrm{CH} \mathrm{U}\end{array}$ & $\mathrm{kg}$ & 3.3487E-05 \\
\hline $\begin{array}{l}\text { Disposal, hazardous waste, } 0 \% \text { water, to underground } \\
\text { deposit/DE U }\end{array}$ & $\mathrm{kg}$ & 7.2936E-06 \\
\hline $\begin{array}{l}\text { Disposal, antifreezer liquid, } 51.8 \% \text { water, to hazardous } \\
\text { waste incineration/CH U }\end{array}$ & $\mathrm{kg}$ & $4.5292 \mathrm{E}-05$ \\
\hline $\begin{array}{l}\text { Disposal, emulsion paint remains, } 0 \% \text { water, to hazardous } \\
\text { waste incineration/ } \mathrm{CH} \mathrm{U}\end{array}$ & $\mathrm{kg}$ & $1.025 \mathrm{E}-07$ \\
\hline
\end{tabular}




\subsubsection{Inventário Consolidado da extração de petróleo internacional}

A Tabela 23 apresenta o inventário consolidado de aspectos ambientais da extração onshore de petróleo na Nigéria.

Tabela 23: Inventário da extração de $1 \mathrm{~kg}$ petróleo onshore - Nigéria

\begin{tabular}{|c|c|c|}
\hline Entradas/saídas & Unidade & Quantidade \\
\hline \multicolumn{3}{|l|}{ Entradas } \\
\hline Oil, crude & $\mathrm{kg}$ & 1.00 \\
\hline Discharge, produced water, onshore/GLO U & $\mathrm{kg}$ & 0,4243 \\
\hline Chemicals inorganic, at plant/GLO U & $\mathrm{kg}$ & $1,2 \mathrm{E}-06$ \\
\hline Chemicals organic, at plant/GLO U & $\mathrm{kg}$ & $8,95 \mathrm{E}-07$ \\
\hline Transport, lorry $>16 t$, fleet average/RER $U$ & tkm & $3,64 \mathrm{E}-05$ \\
\hline Transport, freight, rail/RER U & $\mathrm{tkm}$ & $1,26 \mathrm{E}-06$ \\
\hline Natural gas, vented/GLO U & $\mathrm{m}^{3}$ & 0,021964 \\
\hline Natural gas, sweet, burned in production flare/MJ/GLO U & MJ & 4,629371 \\
\hline Sweet gas, burned in gas turbine, production/MJ/NO U & MJ & 1,360089 \\
\hline Well for exploration and production, onshore/GLO/I U & $\mathrm{m}$ & 4,07E-06 \\
\hline Production plant crude oil, onshore/GLO/I U & $\mathrm{p}$ & $1,24 \mathrm{E}-10$ \\
\hline Platform, crude oil, offshore/OCE/I U & $p$ & $4,15 E-11$ \\
\hline Pipeline, crude oil, onshore/RER/I U & $\mathrm{km}$ & $6,94 \mathrm{E}-09$ \\
\hline \multicolumn{3}{|l|}{ Emissões para o Ar } \\
\hline Methane, bromotrifluoro-, Halon 1301 & $\mathrm{~kg}$ & $5,81 E-08$ \\
\hline \multicolumn{3}{|l|}{ Emissões para a Água } \\
\hline Oils, unspecified & $\mathrm{kg}$ & $6,39 E-05$ \\
\hline BOD5, Biological Oxygen Demand & $\mathrm{kg}$ & 0,000201 \\
\hline COD, Chemical Oxygen Demand & $\mathrm{kg}$ & 0,000201 \\
\hline DOC, Dissolved Organic Carbon & $\mathrm{kg}$ & $5,52 E-05$ \\
\hline TOC, Total Organic Carbon & $\mathrm{kg}$ & 5,52E-05 \\
\hline AOX, Adsorbable Organic Halogen as $\mathrm{Cl}$ & $\mathrm{kg}$ & $6,58 \mathrm{E}-10$ \\
\hline Nitrogen & $\mathrm{kg}$ & 4,93E-08 \\
\hline Sulfur & $\mathrm{kg}$ & $1,71 \mathrm{E}-07$ \\
\hline \multicolumn{3}{|l|}{ Resíduos Sólidos para tratamento } \\
\hline Low active radioactive waste/CH U & $m^{3}$ & 1,99E-09 \\
\hline $\begin{array}{l}\text { Disposal, municipal solid waste, } 22.9 \% \text { water, to } \\
\text { municipal incineration/ } \mathrm{CH} \mathrm{U}\end{array}$ & $\mathrm{kg}$ & 0,000362 \\
\hline
\end{tabular}


A Tabela 24 apresenta o inventário consolidado de aspectos ambientais da extração onshore de petróleo na Argélia.

Tabela 24: Inventário da extração de $1 \mathrm{~kg}$ petróleo onshore - Argélia

\begin{tabular}{|c|c|c|}
\hline Entradas/saídas & Unidade & Quantidade \\
\hline \multicolumn{3}{|l|}{ Entradas } \\
\hline Gas, natural $/ \mathrm{m}^{3}$ & $\mathrm{~m}^{3}$ & 0,00008 \\
\hline Oil, crude & $\mathrm{kg}$ & 1 \\
\hline Water, unspecified natural origin $/ \mathrm{m}^{3}$ & $\mathrm{~m}^{3}$ & 0,00409 \\
\hline Chemicals inorganic, at plant/GLO U & $\mathrm{kg}$ & 0,00012 \\
\hline Chemicals organic, at plant/GLO U & $\mathrm{kg}$ & 0,00009 \\
\hline Transport, lorry $>16 t$, fleet average/RER $U$ & $\mathrm{tkm}$ & 0,000031 \\
\hline Transport, freight, rail/RER $U$ & $\mathrm{tkm}$ & 0,000126 \\
\hline Well for exploration and production, onshore/GLO/I U & $\mathrm{m}$ & $4,35 \mathrm{E}-06$ \\
\hline Pipeline, crude oil, onshore/RER/I U & $\mathrm{km}$ & 7,7E-09 \\
\hline Production plant crude oil, onshore/GLO/I U & $\mathrm{p}$ & $1,38 \mathrm{E}-10$ \\
\hline Diesel, burned in diesel-electric generating set/GLO U & MJ & 0,357 \\
\hline Electricity, low voltage, production UCTE, at grid/UCTE U & $\mathrm{kWh}$ & 0,074203 \\
\hline Natural gas, vented/GLO U & $\mathrm{m}^{3}$ & 0,003753 \\
\hline Natural gas, sweet, burned in production flare/MJ/GLO U & MJ & 1,9962 \\
\hline Sweet gas, burned in gas turbine, production/MJ/NO U & MJ & 0,18006 \\
\hline $\begin{array}{l}\text { Heavy fuel oil, burned in industrial furnace } 1 \mathrm{MW} \text {, non- } \\
\text { modulating/RER } \mathrm{R}\end{array}$ & MJ & 0,24 \\
\hline Discharge, produced water, onshore/GLO U & $\mathrm{kg}$ & 0,42493 \\
\hline \multicolumn{3}{|l|}{ Emissões para o Ar } \\
\hline Methane, bromotrifluoro-, Halon 1301 & $\mathrm{~kg}$ & $5,82 \mathrm{E}-08$ \\
\hline Methane, fossil & $\mathrm{kg}$ & 0,000025 \\
\hline $\begin{array}{l}\text { NMVOC, non-methane volatile organic compounds, } \\
\text { unspecified origin }\end{array}$ & $\mathrm{kg}$ & 0,000075 \\
\hline \multicolumn{3}{|l|}{ Emissões para a Água } \\
\hline Oils, unspecified & $\mathrm{kg}$ & 7,97E-05 \\
\hline BOD5, Biological Oxygen Demand & $\mathrm{kg}$ & 0,000251 \\
\hline COD, Chemical Oxygen Demand & $\mathrm{kg}$ & 0,000251 \\
\hline DOC, Dissolved Organic Carbon & $\mathrm{kg}$ & $6,9 \mathrm{E}-05$ \\
\hline TOC, Total Organic Carbon & $\mathrm{kg}$ & $6,9 \mathrm{E}-05$ \\
\hline AOX, Adsorbable Organic Halogen as $\mathrm{Cl}$ & $\mathrm{kg}$ & $8,21 \mathrm{E}-10$ \\
\hline Nitrogen & $\mathrm{kg}$ & $6,16 \mathrm{E}-08$ \\
\hline Sulfur & $\mathrm{kg}$ & $2,13 \mathrm{E}-07$ \\
\hline \multicolumn{3}{|l|}{ Resíduos Sólidos para tratamento } \\
\hline Low active radioactive waste/CH U & $\mathrm{m}^{3}$ & $2 \mathrm{E}-07$ \\
\hline $\begin{array}{l}\text { Disposal, municipal solid waste, } 22.9 \% \text { water, to } \\
\text { municipal incineration/CH U }\end{array}$ & $\mathrm{kg}$ & 0,0001 \\
\hline
\end{tabular}


A Tabela 25 apresenta o inventário consolidado de aspectos ambientais da extração onshore de petróleo nos fornecedores brasileiros localizados no Oriente Médio.

Tabela 25: Inventário da extração de $1 \mathrm{~kg}$ petróleo onshore - Arábia Saudita, Líbia e Iraque

\section{Entradas/saídas}

\section{Entradas}

Oil, crude

Water, unspecified natural origin $/ \mathrm{m}^{3}$

Chemicals inorganic, at plant/GLO U

Chemicals organic, at plant/GLO U

Transport, lorry $>16 t$, fleet average/RER $U$

Transport, freight, rail/RER $U$

Well for exploration and production, onshore/GLO/I U

Pipeline, crude oil, onshore/RER/I U

Production plant crude oil, onshore/GLO/I U

Diesel, burned in diesel-electric generating set/GLO U

Natural gas, vented/GLO U

Natural gas, sweet, burned in production flare/MJ/GLO U

Heavy fuel oil, burned in industrial furnace $1 \mathrm{MW}$, nonmodulating/RER $U$

Discharge, produced water, onshore/GLO U

\section{Emissões para o Ar}

Methane, bromotrifluoro-, Halon 1301

Methane, fossil

NMVOC, non-methane volatile organic compounds, unspecified origin

\section{Emissões para a Água}

Oils, unspecified

BOD5, Biological Oxygen Demand

COD, Chemical Oxygen Demand

DOC, Dissolved Organic Carbon

TOC, Total Organic Carbon

AOX, Adsorbable Organic Halogen as $\mathrm{Cl}$

Nitrogen

Sulfur

\section{Resíduos Sólidos para tratamento}

Low active radioactive waste/ $\mathrm{CH} \mathrm{U}$

Disposal, municipal solid waste, $22.9 \%$ water, to municipal incineration/CH U

Unidade

Quantidade

$\begin{array}{cc}\mathrm{kg} & 1 \\ \mathrm{~m}^{3} & 0,00409 \\ \mathrm{~kg} & 0,00012 \\ \mathrm{~kg} & 0,00009 \\ \mathrm{tkm} & 0,000031 \\ \mathrm{tkm} & 0,000126 \\ \mathrm{~m} & 1,63 \mathrm{E}-06 \\ \mathrm{~km} & 7,7 \mathrm{E}-09 \\ \mathrm{p} & 1,38 \mathrm{E}-10 \\ \mathrm{MJ} & 0,347 \\ \mathrm{~m} & 0,001269 \\ \mathrm{MJ} & 0,5017 \\ \mathrm{MJ} & 0,24 \\ \mathrm{~kg} & 0,42493\end{array}$

$\mathrm{kg}$

$5,82 \mathrm{E}-08$

$\mathrm{kg}$

0,000025

$\mathrm{kg}$

0,000075

$\begin{array}{ll}\text { kg } & 1,06 \mathrm{E}-05 \\ \text { kg } & 3,35 \mathrm{E}-05 \\ \text { kg } & 3,35 \mathrm{E}-05 \\ \text { kg } & 9,19 \mathrm{E}-06 \\ \text { kg } & 9,19 \mathrm{E}-06 \\ \text { kg } & 1,09 \mathrm{E}-10 \\ \text { kg } & 8,21 \mathrm{E}-09 \\ \text { kg } & 2,84 \mathrm{E}-08\end{array}$

$\mathrm{m}^{3}$

2E-07

$\mathrm{kg}$

0,0001 


\subsubsection{Subsistema Extração de Gás Natural}

O gás natural, assim como a nafta derivada de petróleo, é matéria-prima fundamental para a produção de eteno. Deste modo, o subsistema extração de gás natural complementa a primeira etapa do processo de manufatura do poliestireno, na qual são levantados os aspectos ambientais da obtenção dos recursos naturais.

A seguir estão apresentadas as definições de escopo pertinentes a este subsistema.

a. Fonte de dados: Todos os dados correspondem a fontes secundárias de informação;

b. Cobertura Temporal: os dados referentes ao volume de gás natural consumido compreendem os anos de 2009 a 2010. As exceções estão relacionadas ao uso de bancos de dados para o processo de extração deste mesmo recurso.

c. Cobertura Geográfica: Estado do Rio de Janeiro e Bolívia.

d. Critério de Exclusão: contribuição mássica cumulativa de $90 \%$ de todo o recurso importado para o Brasil.

e. Cobertura tecnológica: extração offshore de gás natural associado no Brasil e extração onshore de gás natural na Bolívia.

\subsubsection{Determinação do percentual de Gás Natural Nacional e Importado}

A relação entre a quantidade de gás natural nacional e importado utilizado no presente sistema de produto foi condicionada às informações existentes no Balanço Energético Nacional - BEN (EPE, 2012), no Anuário Estatístico Brasileiro do Petróleo, Gás Natural e Biocombustíveis (2011) e nas características do contrato firmado entre Brasil e Bolívia.

Assim, em primeira instância, foram avaliados os dados sobre o volume de gás natural importado, produzido e consumido nacionalmente. Segundo o EPE (2012) e a ANP (2011), a diferença entre a oferta total deste recurso e o seu consumo, para os anos 2009 e 2010, foi da ordem de 7.000 milhões de m³/ano, conforme apresenta a Tabela 26. 
Tabela 26: Volume de gás natural importado, produzido e consumido no Brasil - 2009 e 2010 (BEN, 2012).

\begin{tabular}{|c|c|c|}
\hline \multirow{2}{*}{ Origem } & \multicolumn{2}{|c|}{ Volume de gás natural ( $\left.\mathrm{Mm}^{3} / \mathrm{ano}\right)$} \\
\hline & 2009 & 2010 \\
\hline Nacional & 21.137 & 22.938 \\
\hline Importado & 8.366 & 12.647 \\
\hline Total & 37.426 & 42.859 \\
\hline Consumido & 21.580 & 28.311 \\
\hline Variação entre oferta e consumo & 7.923 & 7.274 \\
\hline
\end{tabular}

Tal variação, de acordo com o BEN (EPE, 2012) está fundamentada no não aproveitamento e na reinjeção do gás natural ofertado no Brasil.

Ainda segundo a mesma fonte de informação, todo o gás natural importado neste período é originário da Bolívia, conforme evidencia a Tabela 27.

Tabela 27: Importação de gás natural, segundo países de procedência - 2009 e 2010 (ANP, 2011).

\begin{tabular}{lccc}
\hline \multicolumn{1}{c}{ País de Origem } & Volume de gás natural importado $\left(\mathrm{Mm}^{3}\right)$ & \% de Contribuição \\
\hline Bolívia & 2009 & 2010 & $100 \%$ \\
\hline Argentina $^{7}$ & 8.108 & 9.820 & $100 \%$ \\
\hline
\end{tabular}

De conhecimento que cerca de 30 milhões de $\mathrm{m}^{3} / \mathrm{dia}$ de gás natural boliviano foram diariamente fornecidos para o Brasil em 2009 e 2010, ratificou-se que as premissas de perdas não se adéquam à condição do gás natural importado (EPE, 2012). Portanto, muito embora com elevado grau de dificuldade, constatou-se que $42 \%$ do gás natural consumido em 2009 e 2010 foram de origem internacional, enquanto $58 \%$ foi resultado da produção brasileira. A Tabela 28 traz valores de oferta de gás natural para o cenário apresentado.

Tabela 28: Média aritmética do percentual de contribuição do gás natural nacional e importado -2009 e 2010.

\begin{tabular}{|c|c|c|c|c|}
\hline \multirow{2}{*}{ Origem } & \multicolumn{3}{|c|}{ Volume de gás natural ( $\left.\mathrm{Mm}^{3} / \mathrm{ano}\right)$} & \multirow{2}{*}{$\begin{array}{c}\% \text { de Contribuição } \\
\text { Média }\end{array}$} \\
\hline & 2009 & 2010 & Média & \\
\hline Nacional & 13.214 & 15.664 & 14.439 & $58 \%$ \\
\hline Importado & 8.366 & 12.647 & 10.506 & $42 \%$ \\
\hline Total & 21.580 & 28.311 & 24.945 & $100 \%$ \\
\hline
\end{tabular}

\footnotetext{
${ }^{7}$ Diferentemente do período de 2002 a 2008, para a cobertura temporal analisada, o Brasil não importou gás natural da Argentina.
} 
Ainda a respeito da oferta de gás natural importado, segundo dados do Ministério de Hidrocarbonetos e Energia da Bolívia, mais de $90 \%$ do volume encaminhado para o Brasil é processado nos campos de extração Sábalo e San Alberto (MHE, 2010). Para o período de 2009 e 2010 , foi identificado que $53,5 \%$ do gás natural boliviano teve sua origem em Sábalo e os demais $46,5 \%$ são extraídos em San Alberto.

No que se refere ao gás natural nacional, dos estados produtores listados pela ANP (2012), apenas São Paulo e Rio de Janeiro se conectam ao Sistema Sudeste/Sul, tal como apresentado na Figura 16.

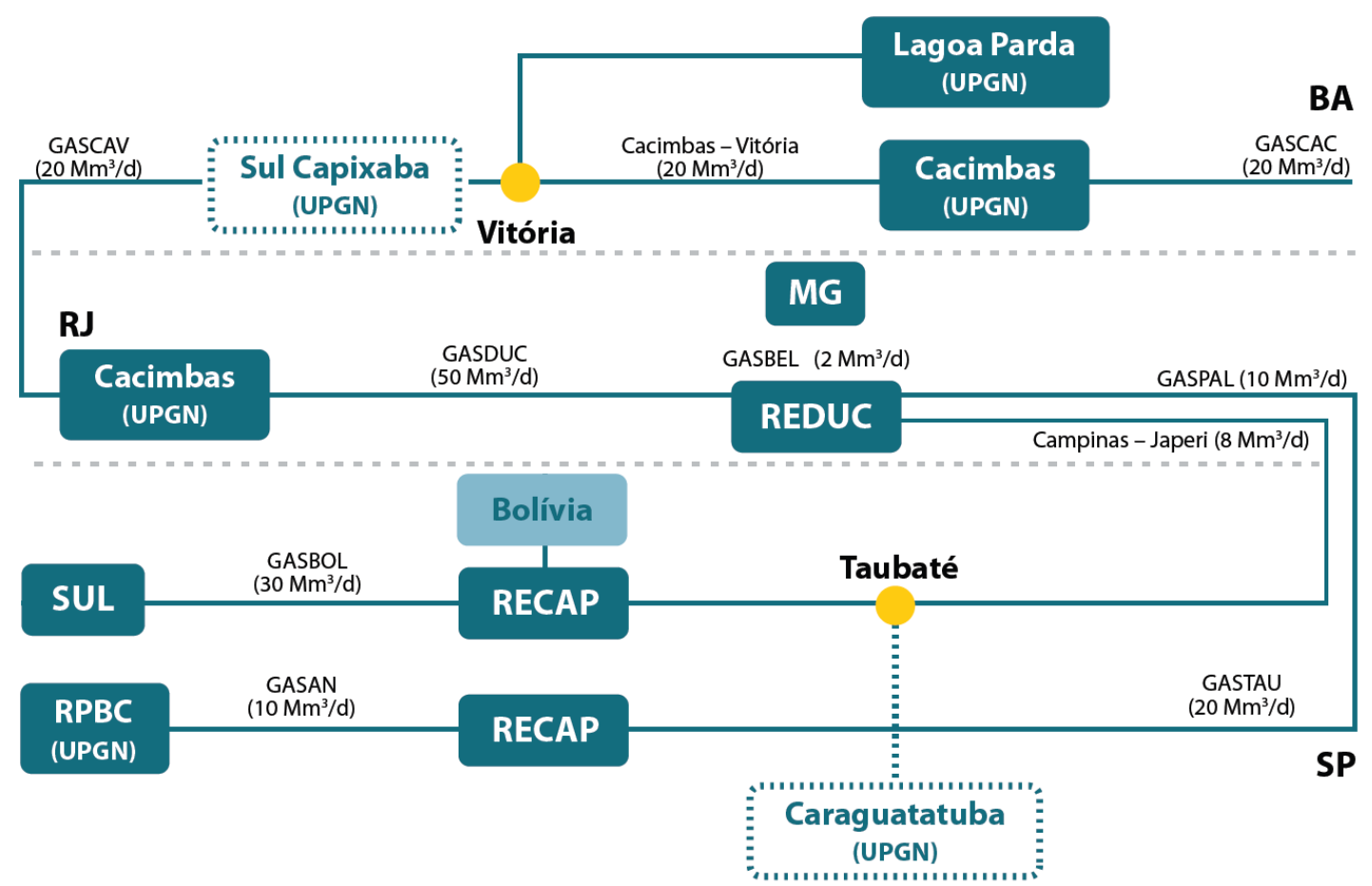

Figura 16: Modelo esquemático da malha de transporte de gás natural no Sistema Sudeste/Sul (CNI, 2010).

Assim, por razão da proximidade e logística de transporte do sistema nacional de gasoduto, apenas estados das regiões Sul e Sudeste foram analisados no quesito oferta de gás natural brasileiro para uso nas refinarias e unidades produtoras de poliestireno.

Desta premissa, observa-se que mais de $90 \%$ do volume de gás natural produzido está centralizado no estado do Rio de Janeiro, conforme evidencia a Tabela 29. 
Tabela 29: Oferta de gás natural, segundo os estados integrados ao estado do RS - 2009 e 2010 (ANP, 2011).

\begin{tabular}{lcccc}
\hline \multicolumn{1}{c}{ Estados } & \multicolumn{2}{c}{ Volume de gás natural importado $\left(\mathbf{M m}^{3}\right)$} & \% de Contribuição \\
\cline { 2 - 5 } & $\mathbf{2 0 0 9}$ & $\mathbf{2 0 1 0}$ & Média & \begin{tabular}{c} 
Média \\
\hline Rio de Janeiro
\end{tabular} \\
\hline São Paulo & 10.497 & 10.132 & 10.315 & $97,4 \%$ \\
TOTAL & 218 & 342 & 280 & $2,6 \%$ \\
\hline
\end{tabular}

\subsubsection{2 $\underline{\text { Transporte }}$}

O transporte de gás natural da Bolívia para as refinarias no Brasil é realizado a partir do gasoduto - GASBOL, evidenciado em linha marrom no mapa da Figura 17. Segundo dados da TBG (2013), o gasoduto GASBOL opera em alta pressão, a fim de transportar o gás proveniente da Bolívia para os estados de Mato Grosso do Sul, São Paulo, Paraná, Santa Catarina e Rio Grande do Sul.

Dos 2997 km de extensão percorridos até a REFAP - penúltima estação de entrega do gasoduto -, cerca de $557 \mathrm{~km}$ encontram-se localizados na Bolívia e $2.440 \mathrm{~km}$ no Brasil (GASNET, 2013). Já para a refinaria localizada no estado de São Paulo, esta distância equivale a aproximadamente $1264 \mathrm{~km}$.

A manutenção das condições de pressão do gás para o transporte ocorre por meio de Estações de Compressão (ECOMPs), as quais fazem uso de turbinas a gás que acionam os compressores. Entre os municípios de Corumbá e Curitiba, a pressão máxima permitida para o transporte é de $100 \mathrm{kgf} / \mathrm{cm}^{2}$, enquanto que nos trechos de Curitiba a Porto Alegre esta pressão cai para $75 \mathrm{kgf} / \mathrm{cm}^{2}$.

De forma análoga, o uso de gasodutos foi considerado para o transporte de gás natural do Rio de Janeiro para São Paulo, cuja distância percorrida é de aproximadamente $420 \mathrm{~km}$. Apesar da inexistência de gasodutos entre os estados de Rio de Janeiro e Rio Grande do Sul, este mesmo meio de transporte foi adotado para quantificar, por aproximação, os aspectos ambientais relacionados ao envio deste insumo. Para tanto, considerou-se uma distância de $975 \mathrm{~km}$ entre o ponto de entrega e recebimento. 


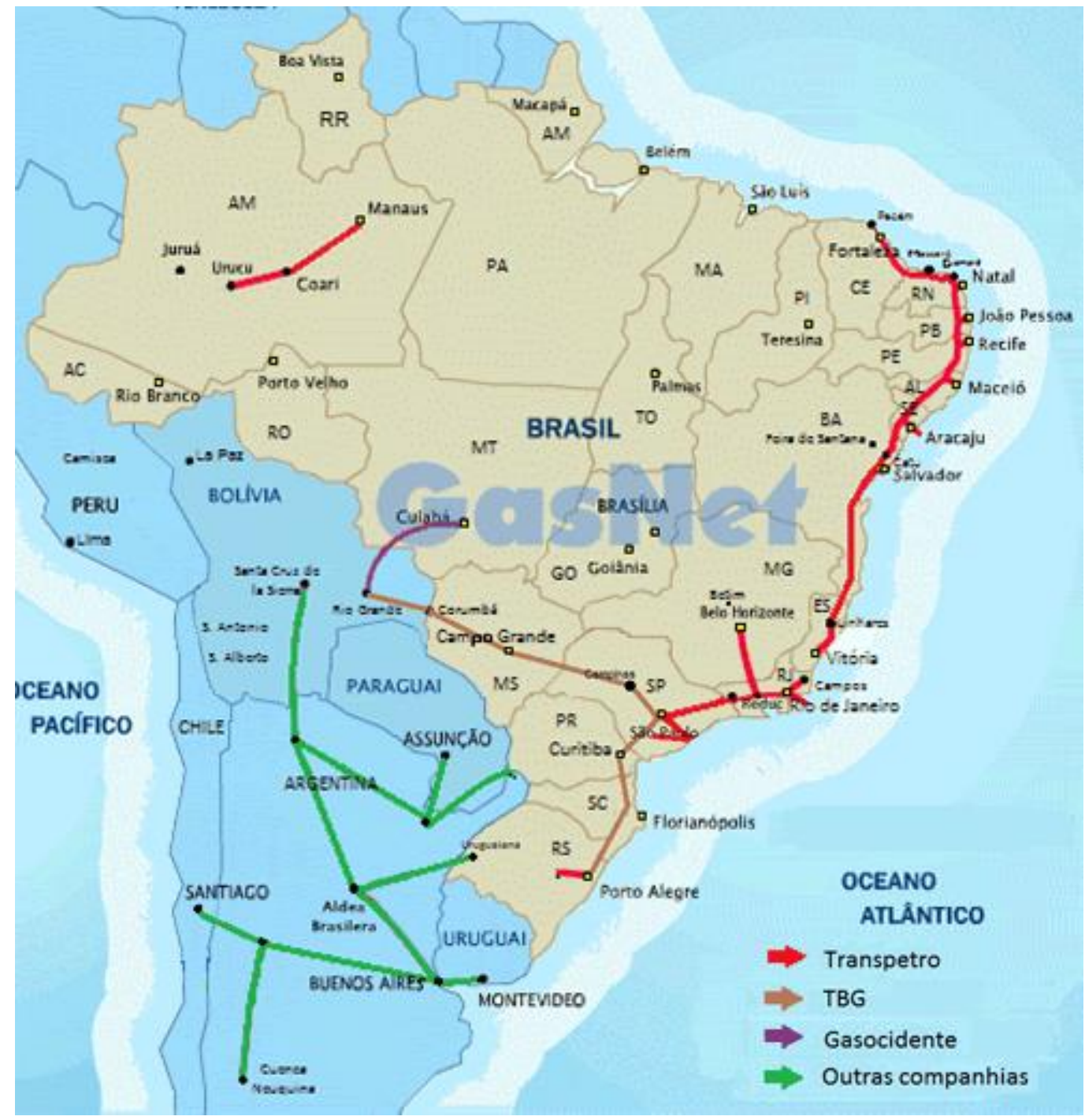

Figura 17: Gasodutos em operação (GASNET, 2013).

\subsubsection{Emissões para atmosfera}

As emissões atmosféricas compreendidas neste subsistema dizem respeito àquelas geradas por perdas no sistema de extração e tratamento do gás natural, bem como pelas falhas e consumo de combustível no transporte e processamento do recurso. Para fins de modelagem, admitiu-se que 3,5\% do gás natural encaminhado da Bolívia para o Brasil é perdido no transporte por falhas de processo.

Já para o cenário de transporte nacional, de acordo com dados da ANP (ANP, 2012) para os anos de 2009 e 2010, a perda de gás natural em relação a sua produção no país foi de 2,0\%. Este valor foi utilizado na quantificação dos fluxos de saída do processo elementar em questão. 


\subsubsection{Emissões para o solo}

A extração de gás natural resulta na geração de efluentes líquidos, em especial quando encontrado associado ao petróleo, que são posteriormente encaminhados para tratamento. Deste processo são gerados lodos que, ao serem descartados como resíduos sólidos, resultam na emissão de poluentes para o solo.

\subsubsection{Emissões para a água}

A geração de efluente aquoso decorrente da extração de gás natural é a principal fonte de poluentes para a água. As características deste efluente são apresentadas nos inventários de extração do gás natural indicado a seguir, e se baseiam em parâmetros obtidos de banco de dados utilizados para este subsistema.

\subsubsection{Banco de dados}

A construção do subsistema de extração de gás natural contou com adoção de bancos de dados contidos na base do Ecoinvent, selecionados de modo a representar o inventário desse subsistema.

Para o caso do gás natural extraído no Brasil, foi selecionado o estudo desenvolvido para a extração offshore de gás associado na Grã Bretanha, o qual inclui as emissões relacionadas ao processamento, consumo de energia e transporte do gás para a costa.

Em contrapartida, os aspectos ambientais do gás natural extraído da Bolívia estão balizados no inventário desenvolvido para a extração onshore de gás natural não associado na Alemanha, cujas emissões estão calculadas para as etapas de extração e processamento.

Os códigos de identificação para os inventários utilizados estão apresentados na Tabela 30. 
Tabela 30: Referências da base de dados do Ecoinvent para a extração de gás natural.

\begin{tabular}{lc}
\hline \multicolumn{1}{c}{ Insumo - Origem } & Código de Identificação - Ecoinvent \\
\hline Gás Natural - Brasil & ESD7571514095100078 \\
Gás Natural - Bolívia & ESD7571514095100090 \\
\hline
\end{tabular}

\subsubsection{Inventário do Ciclo de Vida da Extração de Gás Natural}

A Tabela 31 registra o inventário de cargas ambientais associado a produção de $1 \mathrm{~m}^{3}$ de gás natural no Brasil.

Tabela 31: Inventário da extração de $1 \mathrm{~m}^{3}$ de gás natural - Brasil

\begin{tabular}{|c|c|c|}
\hline Entradas/saídas & Unidade & Quantidade \\
\hline \multicolumn{3}{|l|}{ Entradas } \\
\hline Gas, natural, in ground & $\mathrm{m}^{3}$ & 1,038 \\
\hline Chemicals inorganic, at plant/GLOU & $\mathrm{kg}$ & 4,67E-05 \\
\hline Chemicals organic, at plant/GLO U & $\mathrm{kg}$ & $4,15 \mathrm{E}-05$ \\
\hline Transport, lorry $>16 \mathrm{t}$, fleet average/RER $U$ & $\mathrm{tkm}$ & 8,94E-06 \\
\hline Transport, freight, rail/RER U & $\mathrm{tkm}$ & 5,3E-05 \\
\hline Diesel, at regional storage/RER U & $\mathrm{kg}$ & 0,002259 \\
\hline Heavy fuel oil, at regional storage/RER $U$ & $\mathrm{~kg}$ & 0,001852 \\
\hline \multicolumn{3}{|l|}{ Emissões para o Ar } \\
\hline Heat, waste & MJ & 1,2543 \\
\hline Benzene & $\mathrm{kg}$ & $7,32 \mathrm{E}-12$ \\
\hline Benzo(a)pyrene & $\mathrm{kg}$ & $3,67 \mathrm{E}-14$ \\
\hline Carbon dioxide, fóssil & $\mathrm{kg}$ & 0,001207 \\
\hline Carbon monoxide, fóssil & $\mathrm{kg}$ & 1,53E-06 \\
\hline Dinitrogen monoxide & $\mathrm{kg}$ & $1,29 \mathrm{E}-08$ \\
\hline Helium & $\mathrm{kg}$ & $1,25 \mathrm{E}-07$ \\
\hline Mercury & $\mathrm{kg}$ & $7,52 \mathrm{E}-11$ \\
\hline Methane, fóssil & $\mathrm{kg}$ & $1,53 \mathrm{E}-07$ \\
\hline Nitrogen oxides & $\mathrm{kg}$ & 2,4E-06 \\
\hline $\begin{array}{l}\text { NMVOC, non-methane volatile organic compounds, } \\
\text { unspecified origin }\end{array}$ & $\mathrm{kg}$ & 1,33E-07 \\
\hline Particulates, $>2.5 \mathrm{um}$, and $<10 \mathrm{um}$ & $\mathrm{kg}$ & $1,3 \mathrm{E}-07$ \\
\hline Radon-222 & $\mathrm{kBq}$ & $8,98 \mathrm{E}-05$ \\
\hline Sulfur dioxide & $\mathrm{kg}$ & $1,12 \mathrm{E}-08$ \\
\hline Methane, bromotrifluoro-, Halon 1301 & $\mathrm{~kg}$ & $3,94 \mathrm{E}-10$ \\
\hline \multicolumn{3}{|l|}{ Emissões para a Água } \\
\hline Oils, unspecified & $\mathrm{kg}$ & 0,00053 \\
\hline
\end{tabular}




\begin{tabular}{lcc}
\hline Entradas/saídas & Unidade & Quantidade \\
\hline BOD5, Biological Oxygen Demand & $\mathrm{kg}$ & 0,001666 \\
COD, Chemical Oxygen Demand & $\mathrm{kg}$ & 0,001666 \\
DOC, Dissolved Organic Carbon & $\mathrm{kg}$ & 0,000459 \\
TOC, Total Organic Carbon & $\mathrm{kg}$ & 0,000459 \\
AOX, Adsorbable Organic Halogen as Cl & $\mathrm{kg}$ & $5,46 \mathrm{E}-09$ \\
Nitrogen & $\mathrm{kg}$ & $4,08 \mathrm{E}-07$ \\
Sulfur & $\mathrm{kg}$ & $1,42 \mathrm{E}-06$ \\
Resíduos Sólidos para tratamento & & \\
Low active radioactive waste/CH U & $\mathrm{m}$ & $1,08 \mathrm{E}-07$ \\
$\quad$ Disposal, municipal solid waste, 22.9\% water, to municipal \\
incineration/CH U
\end{tabular}

A Tabela 32 traz o ICV associado a produção de $1 \mathrm{~m}^{3}$ de gás natural, segundo processamento praticado na Bolívia.

Tabela 32: Inventário da extração de $1 \mathrm{~m}^{3}$ de gás natural - Bolívia

\begin{tabular}{|c|c|c|}
\hline Entradas/saídas & Unidade & Quantidade \\
\hline \multicolumn{3}{|l|}{ Entradas } \\
\hline Gas, natural, in ground & $m^{3}$ & 1,01 \\
\hline Ethylene glycol, at plant/RER $U$ & $\mathrm{~kg}$ & $2,23 E-05$ \\
\hline Methanol, at regional storage/ $\mathrm{CH} U$ & $\mathrm{~kg}$ & 3,57E-05 \\
\hline Electricity, medium voltage, at grid/DE U & kWh & 0,00977 \\
\hline Transport, lorry $>16 \mathrm{t}$, fleet average/RER $U$ & tkm & 0,000011 \\
\hline Transport, freight, rail/RER $U$ & tkm & $3,48 \mathrm{E}-05$ \\
\hline Sweetening, natural gas/DE U & $m^{3}$ & 0,5 \\
\hline \multicolumn{3}{|l|}{ Emissões para o Ar } \\
\hline Methane, fossil & $\mathrm{kg}$ & 0,000264 \\
\hline Ethane & $\mathrm{kg}$ & 7,92E-06 \\
\hline Propane & $\mathrm{kg}$ & $7,2 \mathrm{E}-06$ \\
\hline Carbon dioxide, fossil & $\mathrm{kg}$ & 0,0114 \\
\hline Carbon monoxide, fossil & $\mathrm{kg}$ & 0,00008 \\
\hline $\begin{array}{l}\text { NMVOC, non-methane volatile organic compounds, } \\
\text { unspecified origin }\end{array}$ & $\mathrm{kg}$ & $2,88 \mathrm{E}-06$ \\
\hline Nitrogen oxides & $\mathrm{kg}$ & $1,28 \mathrm{E}-05$ \\
\hline Sulfur dioxide & $\mathrm{kg}$ & 0,0001 \\
\hline Mercury & $\mathrm{kg}$ & $1,67 \mathrm{E}-10$ \\
\hline Radon-222 & $\mathrm{kBq}$ & 0,000334 \\
\hline Heat, waste & MJ & 0,0826 \\
\hline Resíduos Sólidos para tratamento & & \\
\hline
\end{tabular}




\begin{tabular}{|c|c|c|}
\hline Entradas/saídas & Unidade & Quantidade \\
\hline $\begin{array}{l}\text { Disposal, used mineral oil, } 10 \% \text { water, to hazardous waste } \\
\text { incineration/ } \mathrm{CH} \mathrm{U}\end{array}$ & $\mathrm{kg}$ & 3,17E-05 \\
\hline $\begin{array}{l}\text { Disposal, municipal solid waste, } 22.9 \% \text { water, to sanitary } \\
\text { landfill/CH U }\end{array}$ & $\mathrm{kg}$ & 2,82E-05 \\
\hline $\begin{array}{l}\text { Disposal, wood untreated, } 20 \% \text { water, to municipal } \\
\text { incineration/ } \mathrm{CH} \mathrm{U}\end{array}$ & $\mathrm{kg}$ & 6,14E-06 \\
\hline $\begin{array}{l}\text { Disposal, hazardous waste, } 0 \% \text { water, to underground } \\
\text { deposit/DE U }\end{array}$ & $\mathrm{kg}$ & 3,82E-05 \\
\hline $\begin{array}{l}\text { Disposal, antifreezer liquid, } 51.8 \% \text { water, to hazardous } \\
\text { waste incineration/CH U }\end{array}$ & $\mathrm{kg}$ & 8,64E-08 \\
\hline $\begin{array}{l}\text { Disposal, emulsion paint remains, } 0 \% \text { water, to hazardous } \\
\text { waste incineration/ } \mathrm{CH} U\end{array}$ & $\mathrm{~kg}$ & 3,81E-07 \\
\hline
\end{tabular}

\subsubsection{Subsistema Refino de Petróleo - Produção de Nafta}

As características de escopo deste subsistema incluem:

a. Fonte de dados: Todos os dados correspondem a fontes secundárias de informação;

b. Cobertura Temporal: os dados referentes ao volume de petróleo processado compreendem os anos de 2009 a 2010. As exceções abarcadas dizem respeito à utilização dos bancos de dados para o processo de refino.

c. Cobertura Geográfica: Estados de São Paulo e Rio Grande do Sul, onde se encontram instaladas a REVAP e a REFAP.

d. Critérios de Exclusão: não houve critério de exclusão específico para este subsistema.

Tendo em vista as particularidades do refino de petróleo no Brasil, em que o abastecimento de derivados de primeira geração ocorre, fundamentalmente, em âmbito regional com relação à localização da refinaria - salvo processamentos ocorridos no Estado do Rio de Janeiro e distribuídos para outras regiões do país decidiu-se selecionar dentro da cobertura geográfica de refino de petróleo as unidades REVAP e REFAP.

De acordo com dados proporcionados pela ANP (2011), a REFAP processou o maior volume de petróleo importado do país nos últimos 5 anos. O Gráfico 2 descreve estas contribuições. 


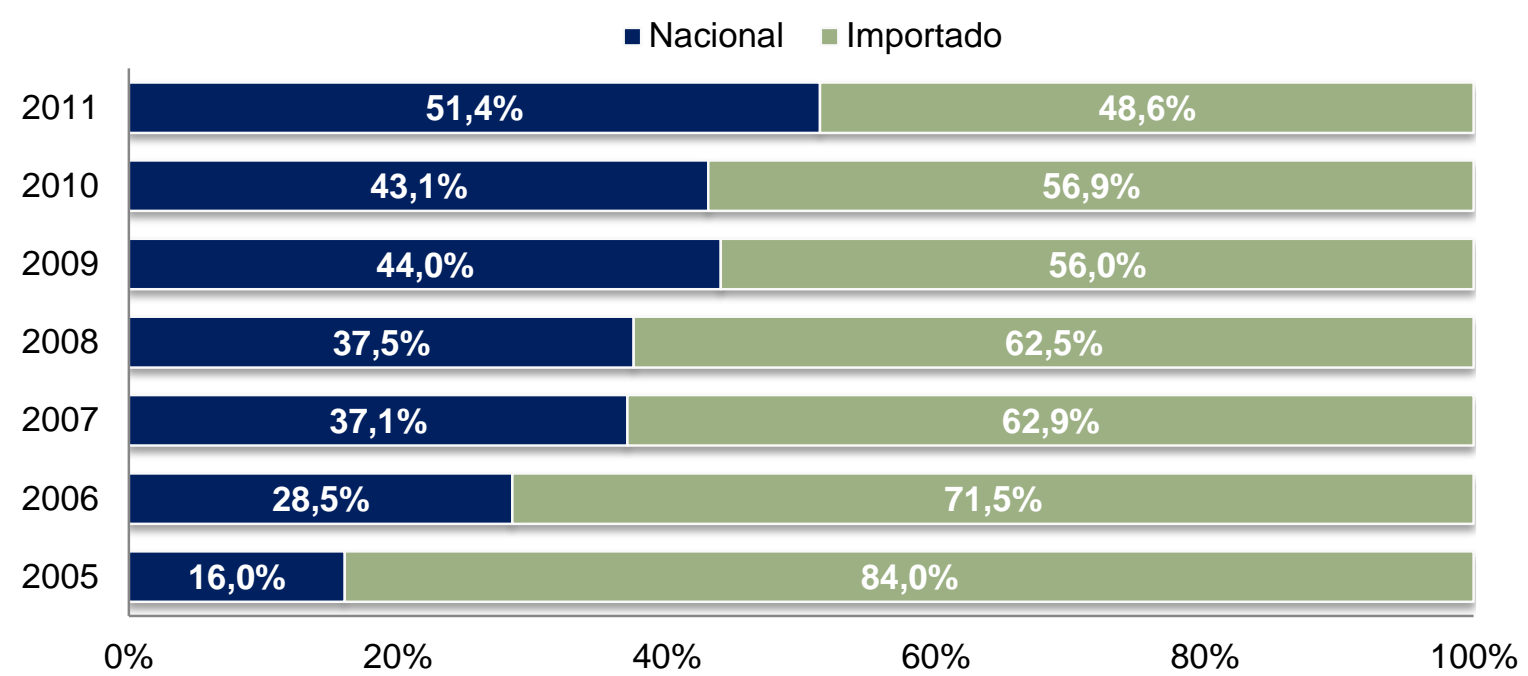

Gráfico 2: Percentual de carga processada pela REFAP, segundo origem nacional e importada (ANP, 2011).

Em contrapartida, a REVAP apresenta um perfil de processamento de petróleo nacional significativamente superior em relação ao volume de petróleo importado, conforme mostra o Gráfico 3.

\begin{tabular}{|c|c|c|}
\hline \multicolumn{3}{|c|}{- Nacional } \\
\hline 2011 & $91,3 \%$ & $8,7 \%$ \\
\hline 2010 & $89,1 \%$ & $10,9 \%$ \\
\hline 2009 & $85,9 \%$ & $14,1 \%$ \\
\hline 2008 & $84,6 \%$ & $15,4 \%$ \\
\hline 2007 & $81,2 \%$ & $18,8 \%$ \\
\hline 2006 & $84,1 \%$ & $15,9 \%$ \\
\hline 2005 & $90,5 \%$ & $9,5 \%$ \\
\hline
\end{tabular}

Gráfico 3: Percentual de carga processada pela REVAP, segundo origem nacional e importada (ANP, 2011).

Assim, a fim de obter o percentual de petróleo processado, por origem, para a cobertura temporal anteriormente definida, foi realizado o cálculo da média aritmética para os anos de 2009 a 2010, considerando o volume de nafta produzida por estas mesmas refinarias. O resultado obtido de $67,5 \%$ de petróleo nacional e $32,5 \%$ de petróleo importado. 


\subsubsection{Critério de Alocação para os derivados de petróleo}

Tendo em vista a característica energética dos derivados de petróleo, o critério de alocação aplicado para a distribuição das cargas ambientais fez uso das propriedades caloríficas dos produtos obtidos neste subsistema.

Assim, segundo informações como: a produtividade de derivados a partir de $1 \mathrm{~kg}$ de petróleo; e, a densidade e poderes caloríficos inferiores desses mesmos derivados (ANP, 2011), foram calculados os fatores de alocação para a nafta. Os resultados esta análise estão apresentados na Tabela 33.

Tabela 33: Determinação para os fatores de alocação

\begin{tabular}{lcccc}
\hline \multicolumn{1}{c}{ Derivados de Petróleo } & Massa [kg] & $\begin{array}{c}\text { Poder Calorífico } \\
{[\mathbf{k c a l} / \mathbf{k g}]}\end{array}$ & $\begin{array}{c}\text { Energia } \\
{[\mathbf{k c a l}]}\end{array}$ & Alocação [\%] \\
\hline Nafta & 0,0503 & $1,06 \mathrm{E}+04$ & $5,35 \mathrm{E}+02$ & $5,59 \%$ \\
\hline Óleo diesel & 0,2080 & $1,01 \mathrm{E}+04$ & $2,10 \mathrm{E}+03$ & $21,97 \%$ \\
\hline Gás Liquefeito de Petróleo, & 0,0266 & $1,11 \mathrm{E}+04$ & $2,95 \mathrm{E}+02$ & $3,09 \%$ \\
\hline Gasolina & 0,3897 & $1,04 \mathrm{E}+04$ & $4,05 \mathrm{E}+03$ & $42,37 \%$ \\
Oleo Combustível & 0,0508 & $9,59 \mathrm{E}+03$ & $4,88 \mathrm{E}+02$ & $5,10 \%$ \\
\hline Asfalto & 0,0358 & $9,79 \mathrm{E}+03$ & $3,50 \mathrm{E}+02$ & $3,66 \%$ \\
\hline Querosene & 0,0860 & $1,04 \mathrm{E}+04$ & $8,94 \mathrm{E}+02$ & $9,35 \%$ \\
Coque & 0,0580 & $8,39 \mathrm{E}+03$ & $4,87 \mathrm{E}+02$ & $5,09 \%$ \\
\hline Gás de refinaria & 0,0326 & $1,11 \mathrm{E}+04$ & $3,62 \mathrm{E}+02$ & $3,78 \%$ \\
\hline Total & $\mathbf{0 , 9 3 7 8}$ & - & $\mathbf{9 , 5 6 E + 0 3}$ & $\mathbf{1 0 0 , 0 \%}$ \\
\hline
\end{tabular}

\subsubsection{Transporte de Nafta}

Após o refino, a nafta e o gás natural utilizados no processo de manufatura de eteno e benzeno são encaminhados à unidade de produção de poliestireno via oleodutos. $A$ distância percorrida entre as plantas foi estimada em $25 \mathrm{~km}$. Para fins de modelagem, assumiu-se que as perdas de produtos no transporte são insignificantes, de tal modo que a quantidade de nafta que parte das refinarias é equivalente à quantidade de nafta recebida nas plantas de eteno e benzeno.

Os aspectos ambientais resultantes do transporte foram extraídos do base de dados do Ecoinvent, desde o elemento "Transport, by pipeline, onshore/ OCE U".

\footnotetext{
8 Valores retirados da ANP, 2011.
} 
Este conjunto de dados foi tratado de maneira a refletir as condições brasileiras de processamento para o ano de 2011, sobretudo no que se refere a cargas ambientais associadas ao consumo de eletricidade.

\subsubsection{Banco de dados utilizado}

A falta de um inventário para a tecnologia de refino de petróleo própria da REVAP e REFAP impôs a busca por dados secundários que expressassem de maneira adequada às cargas ambientais associadas a este processamento. A partir de critérios objetivos, relacionados às coberturas tecnológica e temporal, selecionou-se então junto a Base de Dados Ecoinvent, um inventário do banco de dados LCI - US.

Assim, verificou-se que dentro das opções existentes, este banco de dados compunha as etapas de dessalgação, destilação (atmosférica e a vácuo), além de operações de coqueamento e craqueamento catalítico, tal como o processamento realizado pelas refinarias incorporadas neste estudo.

Além disso, as características de concentração de enxofre no diesel entre ambas as realidades - brasileira e simulada - se assemelham. Esta constatação indica, portanto, a similaridade entre as matérias-primas utilizadas.

Contudo, a fim de adequar o inventário obtido às condições tecnológicas praticadas na REVAP e REFAP, ajustes e adequações referentes à quantidade de derivados produzidos e à matriz energética utilizada foram realizadas.

\subsubsection{Características da Matriz Energética Brasileira}

A adequação da composição das fontes de energia elétrica no subsistema de refino tem por objetivo ajustar o levantamento dos aspectos ambientais referentes ao sistema de produto estudado. Para tanto, foi identificado junto ao Balanço Energético Nacional (EPE, 2012), a oferta interna brasileira de energia elétrica por fonte para o ano de 2011. Os percentuais adotados para a modelagem aparecem no Gráfico 4. 


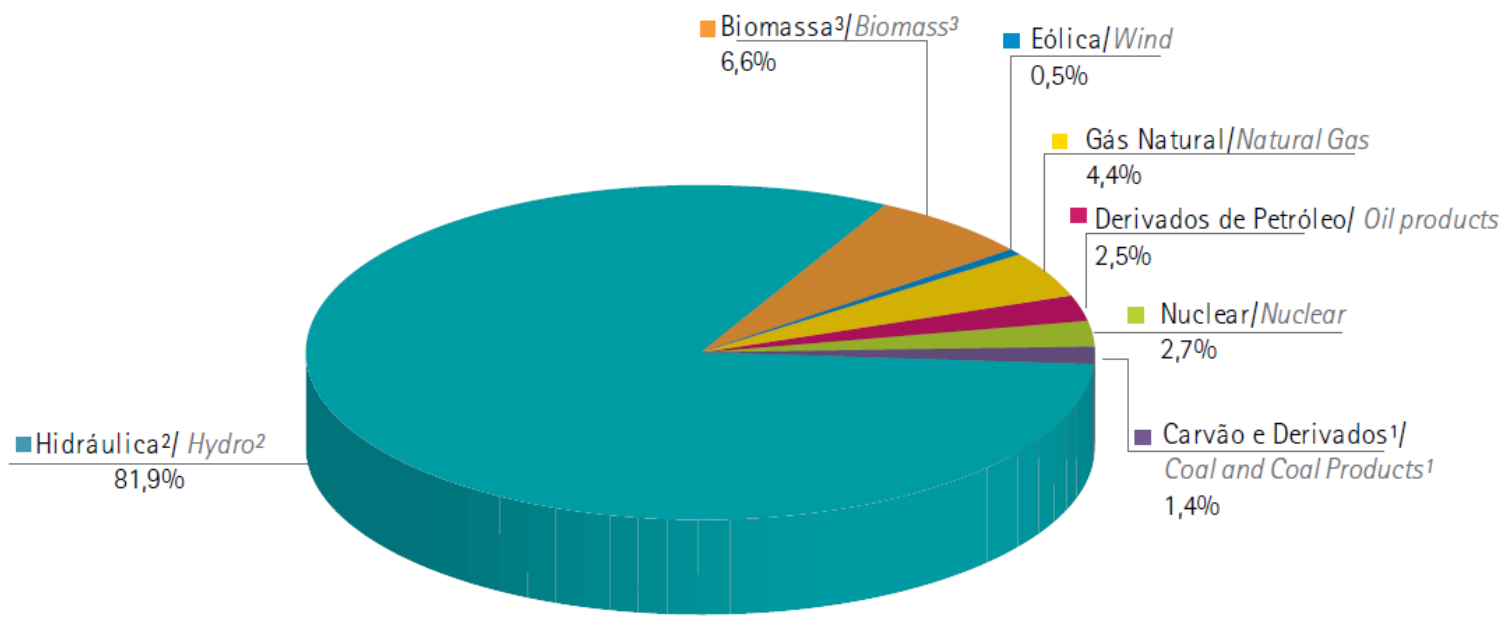

Gráfico 4: Oferta Interna de Energia Elétrica por Fonte - 2011 (BEN, 2012)

Ressalta-se que as emissões resultantes da transmissão de energia também foram aportadas no sistema. Nesse sentido, consideraram-se as perdas de hexafluoreto de enxofre $\left(\mathrm{SF}_{6}\right)^{9}$ e de calor. Em termos numéricos, a transmissão de $1 \mathrm{kWh}$ de energia elétrica em média tensão emite para o ar $0,0068 \mu \mathrm{g}$ de hexafluoreto de enxofre e $0,04614 \mathrm{MJ}$ de calor para a atmosfera, além de $0,03775 \mathrm{MJ}$ de calor para o solo.

\subsubsection{Inventário do Ciclo de Vida do Refino de Petróleo}

A Tabela 34 registra o inventário de cargas ambientais associado ao refino de 1,0kg de petróleo segundo esse processo é conduzido no Brasil.

Tabela 34: Inventário do refino de $1 \mathrm{~kg}$ de petróleo

\begin{tabular}{lcc}
\hline Entradas/saídas & Unidade & Quantidade \\
\hline Produtos & & \\
Coprodutos de refino (Nafta +), at refinery/BR & $\mathrm{kg}$ & 0,05029 \\
Diesel, at refinery/BR & $\mathrm{I}$ & 0,24414 \\
Gas Liquefeito de Petroleo, at refinery/BR & $\mathrm{I}$ & 0,048212 \\
Gasolina mix, at refinery/BR & $\mathrm{I}$ & 0,52518 \\
Oleo Combustivel residuo, at refinery/BR & $\mathrm{I}$ & 0,050188 \\
Base Betuminosa, at refinery/BR & $\mathrm{kg}$ & 0,035783 \\
Querosene mix, at refinery/BR & $\mathrm{I}$ & 0,10881 \\
Coque de petroleo, a refinery/BR & $\mathrm{kg}$ & 0,058027 \\
\hline
\end{tabular}

9 "Gás sintético, utilizado principalmente pela indústria elétrica, como meio isolante e extintor de arco elétrico, tanto em disjuntores, como em uma subestação blindada.” (CETESB, 2011). 
Entradas/saídas
Gas de refinaria mix, at refinery/BR

\section{Entradas}

Crude oil mix BR, transportation - REFAP

Electricity - medium voltage, at grid 2012/ BR

Liquefied petroleum gas, combusted in industrial boiler/US

Natural Gas, at plant/BR

Residual fuel oil, combusted in industrial boiler/US

\section{Emissões para o Ar}

Aldehydes, unspecified

Ammonia

Carbon monoxide, fóssil

Methane, dichlorodifluoro-, CFC-12

Methane, tetrachloro-, CFC-10

Methane, fóssil

Nitrogen oxides

NMVOC, non-methane volatile organic compounds, unspecified origin

Particulates, unspecified

Sulfur oxides

Ethane, 1,1,1-trichloro-, HCFC-140

\section{Emissões para a Água}

Ammonia

BOD5, Biological Oxygen Demand

Chromium VI

Chromium, ion

COD, Chemical Oxygen Demand

Oils, unspecified

Phenols, unspecified

Sulfide

Suspended solids, unspecified

\section{Unidade}

$\mathrm{m}^{3}$

Quantidade

0,059064

$\mathrm{kg}$

1

$\mathrm{kWh}$

0,13359

I

0,000916

$\mathrm{m}^{3}$

0,008851

।

0,02171

$\mathrm{kg}$

4,06E-05

$\mathrm{kg}$

2,03E-05

$\mathrm{kg}$

0,012863

$\mathrm{kg}$

1,16E-10

$\mathrm{kg}$

1,16E-11

$\mathrm{kg}$

6,87E-05

$\mathrm{kg}$

0,000319

$\mathrm{kg}$

0,001963

$\mathrm{kg}$

0,000232

$\mathrm{kg}$

0,002273

$\mathrm{kg}$

$9,38 \mathrm{E}-11$

$\mathrm{kg}$

1,45E-05

$\mathrm{kg}$

3,29E-05

$\mathrm{kg}$

3,58E-08

$\mathrm{kg}$

5,51E-07

$\mathrm{kg}$

0,000222

$\mathrm{kg}$

1,06E-05

$\mathrm{kg}$

2,22E-07

$\mathrm{kg}$

1,84E-07

$\mathrm{kg}$

2,71E-05

\section{Resíduos Sólidos para tratamento}

Dummy_Disposal, solid waste, unspecified, to sanitary landfill/US

$\mathrm{kg}$

0,005416

\subsubsection{Subsistema Produção de Eteno, Benzeno e Polibutadieno}

As características de definição de escopo deste subsistema englobam: 
a. Fonte de dados: secundárias;

b. Cobertura Temporal: os dados referentes a matriz energética dizem respeito ao ano de 2011. Todas as demais coberturas contempladas estão relacionadas aos bancos de dados utilizados.

c. Cobertura Geográfica: estado de São Paulo e Rio Grande do Sul, onde se encontram instaladas as plantas de manufatura de eteno e benzeno. Outras localidades foram inseridas em decorrência da adoção de banco de dados para a produção de Polibutadieno.

d. Limitações: devido à indisponibilidade de dados, para ambos os processos, não foram consideradas emissões atmosféricas decorrentes de combustão.

\subsubsection{Banco de Dados}

Os processos de produção de eteno e de benzeno foram modelados a partir de inventários coletados no Banco de Dados LCI-USA, enquanto que para o polibutadieno adotou-se um modelo constante no Ecoinvent. Para ambos os casos, efetuou-se um levantamento das rotas de produção empregadas para síntese dos respectivos intermediários de processo.

Simultaneamente a isso, procedeu-se uma aferição da frequência com que cada tecnologia de produção é exercitada no país, tal como descrito anteriormente.

De posse desses dados foi então possível selecionar, dentre as opções de Bancos de Dados disponíveis, aquelas rotas que mais se aproximassem das condições exercitadas no país. Tem-se por resultado que o desempenho ambiental associado à produção de eteno foi modelado a partir do craqueamento a vapor, já para a obtenção de benzeno decidiu-se pela rota de reforma catalítica e para a manufatura de polibutadieno a extração destilativa. Tais tecnologias constam da Tabela 35.

Tabela 35: Modelagem utilizada do SimaPro para produção de intermediários

\begin{tabular}{ccc}
\hline Produto & U.S. LCI Database & Rota Tecnológica \\
\hline Eteno & Processo ESD7571514095101070 & Craqueamento térmico a vapor de Nafta e \\
Benzeno & Processo ESD7571514095101069 & Reforma catalítica de nafta \\
Polibutadieno & Processo ESD7571514095101024 & Extração destilativa \\
\hline
\end{tabular}




\subsubsection{Transporte de eteno e benzeno}

O transporte de eteno e benzeno até a unidade de poliestireno é realizado via tubovias. Para efeito de modelagem, considerou-se que ambas as plantas estão localizadas a uma distância de 2,5km. Visto a diminuta distância, assumiu-se que as perdas de produtos no transporte são insignificantes, o que predispõe que a quantidade de insumos que deixa a indústria de intermediários é igual à quantidade recebida na planta de GPPS e HIPS, havendo para tanto o consumo de energia elétrica.

No que tange ao polibutadieno, verifica-se que parte da matéria-prima advém do estado de Pernambuco e outro montante é produzido em São Paulo, atribuindo cargas ambientais a este subsistema em decorrência dos transportes requeridos até as refinarias.

Para efeito de modelagem, considerou-se que o polibutadieno manufaturado em Pernambuco percorre uma distância de $200 \mathrm{~km}$ em caminhões da fábrica ao porto daquele estado, além de perfazer $3000 \mathrm{~km}$ em vias marítimas entre o porto de origem e os portos de destino, adicionados de $100 \mathrm{~km}$ por modal rodoviário do porto de destino à unidade produtora de HIPS.

Já para o polibutadieno manufaturado em São Paulo, verificou-se que a distância média entre as unidades produtoras deste insumo e de poliestireno é de aproximadamente $400 \mathrm{~km}$.

Os aspectos ambientais decorrentes dos transportes foram incorporados no estudo a partir dos bancos de dados apontados na Tabela 36.

Tabela 36: Banco de dados adotados para os sistemas de transporte de petróleo cru

\begin{tabular}{cc}
\hline Sistema de Transporte & Banco de Dados \\
\hline Transoceânico & Transport, transoceanic tanker/OCE U \\
Rodoviário & Transport, lorry 3.5-7.5t, EURO4/RER U \\
Oleoduto & Transport, by pipeline, onshore/ OCE U \\
\hline
\end{tabular}

\subsubsection{Inventários do Ciclo de Vida do eteno e do benzeno}

A Tabela 37 descreve em termos de cargas ambientais o ICV da produção de eteno $\left(\mathrm{C}_{2} \mathrm{H}_{4}\right)$. 
Tabela 37: Inventário da produção de $1 \mathrm{~kg}$ de eteno

\begin{tabular}{|c|c|c|}
\hline Entradas/saídas & Unidade & Quantidade \\
\hline \multicolumn{3}{|l|}{ Entradas } \\
\hline Electricity - medium voltage, at grid 2012/ BR & $\mathrm{kWh}$ & 0,146607 \\
\hline Electricity, at cogenerating unit, unspecified/BR & $\mathrm{kWh}$ & 0 \\
\hline Natural Gas, at plant/BR & $\mathrm{m}^{3}$ & 1,3704 \\
\hline Diesel, at refinery/BR & 1 & $8,35 \mathrm{E}-05$ \\
\hline Gasolina mix, at refinery/BR & I & $9,18 \mathrm{E}-05$ \\
\hline Coprodutos de refino $(\mathrm{Nafta}+)$, transportation $^{10}$ & $\mathrm{~kg}$ & 0,237 \\
\hline Coprodutos de refino (Nafta + ), transportation ${ }^{11}$ & $\mathrm{~kg}$ & 0,0334 \\
\hline \multicolumn{3}{|l|}{ Emissões para o Ar } \\
\hline Methane & $\mathrm{kg}$ & 0.000017 \\
\hline Aldehydes, unspecified & $\mathrm{kg}$ & $1 \mathrm{E}-10$ \\
\hline Carbon dioxide & $\mathrm{kg}$ & 0.001 \\
\hline Carbon monoxide & $\mathrm{kg}$ & 0.000056 \\
\hline Chlorine & $\mathrm{kg}$ & $1 \mathrm{E}-07$ \\
\hline $\begin{array}{l}\text { Chlorinated fluorocarbons and hydrochlorinated } \\
\text { fluorocarbons, unspecified }\end{array}$ & $\mathrm{kg}$ & $1 \mathrm{E}-09$ \\
\hline $\begin{array}{l}\text { NMVOC, non-methane volatile organic compounds, } \\
\text { unspecified origin }\end{array}$ & $\mathrm{kg}$ & 0.000053 \\
\hline Hydrogen & $\mathrm{kg}$ & $1.1 \mathrm{E}-06$ \\
\hline Hydrogen chloride & $\mathrm{kg}$ & $1 \mathrm{E}-09$ \\
\hline Dinitrogen monoxide & $\mathrm{kg}$ & 0.000001 \\
\hline Nitrogen oxides & $\mathrm{kg}$ & 0.00001 \\
\hline Organic substances, unspecified & $\mathrm{kg}$ & 0.000001 \\
\hline Particulates, unspecified & $\mathrm{kg}$ & $7.5 \mathrm{E}-06$ \\
\hline Particulates, $<2.5$ um & $\mathrm{kg}$ & 0.000001 \\
\hline Particulates, $>2.5 \mathrm{um}$, and $<10 \mathrm{um}$ & $\mathrm{kg}$ & 0.000047 \\
\hline Sulfur oxides & $\mathrm{kg}$ & 0.000023 \\
\hline VOC, volatile organic compounds & $\mathrm{kg}$ & 0.00001 \\
\hline \multicolumn{3}{|l|}{ Emissões para a Água } \\
\hline Acetone & $\mathrm{kg}$ & $1 \mathrm{E}-12$ \\
\hline Benzene & $\mathrm{kg}$ & $1 \mathrm{E}-08$ \\
\hline BOD5, Biological Oxygen Demand & $\mathrm{kg}$ & 4.1E-07 \\
\hline COD, Chemical Oxygen Demand & $\mathrm{kg}$ & 0.00001 \\
\hline Benzene, ethyl- & $\mathrm{kg}$ & $1 \mathrm{E}-08$ \\
\hline
\end{tabular}

10 Parcela que representa a mistura de coprodutos de refino de petróleo que efetivamente será empregada produção de eteno.

${ }^{11}$ Parcela que representa os coprodutos de refino recuperados da produção e que serão empregados para fornecer energia para a mesma unidade. 


\begin{tabular}{lcc}
\hline Entradas/saídas & Unidade & Quantidade \\
\hline Naphthalene & $\mathrm{kg}$ & $1 \mathrm{E}-12$ \\
Phenols, unspecified & $\mathrm{kg}$ & $1 \mathrm{E}-07$ \\
Styrene & $\mathrm{kg}$ & $1 \mathrm{E}-10$ \\
Toluene & $\mathrm{kg}$ & $1 \mathrm{E}-07$ \\
TOC, Total Organic Carbon & $\mathrm{kg}$ & 0.000001 \\
Suspended solids, unspecified & $\mathrm{kg}$ & $2.6 \mathrm{E}-06$ \\
Xylene & $\mathrm{kg}$ & $1 \mathrm{E}-10$ \\
Resíduos Sólidos para tratamento & & \\
$\quad$ Dummy_Disposal, solid waste, unspecified, to sanitary & $\mathrm{kg}$ & 0.00029 \\
landfill/US & & \\
Dummy_Disposal, solid waste, unspecified, to municipal & $\mathrm{kg}$ & 0.003623 \\
incineration/US & & \\
\hline
\end{tabular}

A Tabela 38 da abordagem semelhante à daquela que a sucede ao descrever, de sua parte, as cargas ambientais do ICV da produção de benzeno $\left(\mathrm{C}_{6} \mathrm{H}_{6}\right)$.

Tabela 38: Inventário da produção de $1 \mathrm{~kg}$ de benzeno

\begin{tabular}{lcc}
\hline Entradas/saídas & Unidade & Quantidade \\
\hline Entradas & $\mathrm{kWh}$ & 0,024956 \\
Electricity - medium voltage, at grid 2012/ BR & $\mathrm{kWh}$ & 0 \\
Electricity, at cogenerating unit, unspecified/BR & $\mathrm{m}^{3}$ & 0,07313 \\
Natural Gas, at plant/BR & $\mathrm{I}$ & 0,003338 \\
Diesel, at refinery/BR & $\mathrm{I}$ & 0,032297 \\
Oleo Combustivel residuo, at refinery/BR & $\mathrm{kg}$ & 0,024956 \\
Natural Gas, at plant/BR & $\mathrm{kg}$ & 0,667 \\
Coprodutos de refino (Nafta +), transportation ${ }^{12}$ & & 0,012 \\
Coprodutos de refino (Nafta +), transportation ${ }^{13}$ & & 0,335 \\
Pirolise de Gasolina, at plant/BR & & \\
Emissões para o Ar & & 0.0301 \\
Carbon dioxide & $\mathrm{kg}$ & 0.00001 \\
Carbon monoxide & $\mathrm{kg}$ & $1 \mathrm{E}-07$ \\
Chlorine & $\mathrm{kg}$ & 0.00001 \\
NMVOC, non-methane volatile organic compounds, & $\mathrm{kg}$ & \\
unspecified origin
\end{tabular}

12 Parcela que representa a mistura de coprodutos de refino de petróleo que efetivamente será empregada produção de benzeno.

${ }^{13}$ Parcela que representa os coprodutos de refino recuperados da produção e que serão empregados para fornecer energia para a mesma unidade. 


\begin{tabular}{lcc}
\hline Entradas/saídas & Unidade & Quantidade \\
\hline Hydrogen & $\mathrm{kg}$ & $1 \mathrm{E}-09$ \\
Nitrogen oxides & $\mathrm{kg}$ & 0.000042 \\
Particulates, unspecified & $\mathrm{kg}$ & 0.00002 \\
Particulates, $<2.5$ um & $\mathrm{kg}$ & 0.00001 \\
Particulates, > 2.5 um, and <10um & $\mathrm{kg}$ & 0.000001 \\
Sulfur oxides & $\mathrm{kg}$ & 0.0003 \\
Emissões para a Água & & \\
Acetone & $\mathrm{kg}$ & $1 \mathrm{E}-12$ \\
Benzene & $\mathrm{kg}$ & $1 \mathrm{E}-08$ \\
BOD5, Biological Oxygen Demand & $\mathrm{kg}$ & $4.1 \mathrm{E}-07$ \\
COD, Chemical Oxygen Demand & $\mathrm{kg}$ & 0.00001 \\
Benzene, ethyl- & $\mathrm{kg}$ & $1 \mathrm{E}-08$ \\
Naphthalene & $\mathrm{kg}$ & $1 \mathrm{E}-12$ \\
Phenols, unspecified & $\mathrm{kg}$ & $1 \mathrm{E}-07$ \\
Styrene & $\mathrm{kg}$ & $1 \mathrm{E}-10$ \\
Toluene & $\mathrm{kg}$ & $1 \mathrm{E}-07$ \\
TOC, Total Organic Carbon & $\mathrm{kg}$ & 0.000001 \\
Suspended solids, unspecified & $\mathrm{kg}$ & $2.6 \mathrm{E}-06$ \\
Xylene & $\mathrm{kg}$ & $1 \mathrm{E}-10$ \\
Resíduos Sólidos para tratamento & & \\
Dummy_Disposal, solid waste, unspecified, to sanitary & $\mathrm{kg}$ & 0.00029 \\
landfill/US & $\mathrm{kg}$ & 0.003623 \\
Dummy_Disposal, solid waste, unspecified, to municipal & & \\
incineration/US & & \\
\hline
\end{tabular}

A Tabela 39 traz inventariados consumos e gerações associados a produção de 1,0kg de polibutadieno.

Tabela 39: Inventário da produção de $1 \mathrm{~kg}$ de polibutadieno

\begin{tabular}{lcc}
\hline Entradas/saídas & Unidade & Quantidade \\
\hline Entradas & & \\
Oil, crude, in ground & $\mathrm{kg}$ & 1,2093 \\
Gas, natural, in ground & $\mathrm{m}^{3}$ & 0,90759 \\
Coal, hard, unspecified, in ground & $\mathrm{kg}$ & 0,25121 \\
Coal, brown, in ground & $\mathrm{kg}$ & $1,0487 \mathrm{E}-06$ \\
Peat, in ground & $\mathrm{kg}$ & 0,00021389 \\
Wood, unspecified, standing/m³ & $\mathrm{m}^{3}$ & $6,3989 \mathrm{E}-09$ \\
Energy, potential (in hydropower reservoir), converted & $\mathrm{MJ}$ & 0,15418 \\
Uranium, in ground & $\mathrm{kg}$ & $6,8033 \mathrm{E}-06$ \\
Energy, gross calorific value, in biomass & $\mathrm{MJ}$ & 0,25737 \\
\hline
\end{tabular}




\begin{tabular}{|c|c|c|}
\hline Entradas/saídas & Unidade & Quantidade \\
\hline Barite, $15 \%$ in crude ore, in ground & $\mathrm{kg}$ & 1,149E-07 \\
\hline Aluminium, $24 \%$ in bauxite, $11 \%$ in crude ore, in ground & $\mathrm{kg}$ & $5,9547 \mathrm{E}-06$ \\
\hline Clay, bentonite, in ground & $\mathrm{kg}$ & 0,000029042 \\
\hline Anhydrite, in ground & $\mathrm{kg}$ & $2,8956 \mathrm{E}-06$ \\
\hline Calcite, in ground & $\mathrm{kg}$ & 0,00012517 \\
\hline Clay, unspecified, in ground & $\mathrm{kg}$ & $4,6809 E-09$ \\
\hline $\begin{array}{l}\text { Chromium, } 25.5 \% \text { in chromite, } 11.6 \% \text { in crude ore, in } \\
\text { ground }\end{array}$ & $\mathrm{kg}$ & $9,4205 \mathrm{E}-10$ \\
\hline $\begin{array}{l}\text { Copper, } 0.99 \% \text { in sulfide, Cu } 0.36 \% \text { and Mo } 8.2 \mathrm{E}-3 \% \text { in } \\
\text { crude ore, in ground }\end{array}$ & $\mathrm{kg}$ & $7,6165 \mathrm{E}-06$ \\
\hline Dolomite, in ground & $\mathrm{kg}$ & $2,4781 \mathrm{E}-06$ \\
\hline Iron, $46 \%$ in ore, $25 \%$ in crude ore, in ground & $\mathrm{kg}$ & 0,00020234 \\
\hline Feldspar, in ground & $\mathrm{kg}$ & $7,7 \mathrm{E}-17$ \\
\hline $\begin{array}{l}\text { Manganese, } 35.7 \% \text { in sedimentary deposit, } 14.2 \% \text { in } \\
\text { crude ore, in ground }\end{array}$ & $\mathrm{kg}$ & $2,6098 \mathrm{E}-07$ \\
\hline Fluorspar, $92 \%$, in ground & $\mathrm{kg}$ & $6,9933 \mathrm{E}-07$ \\
\hline Granite, in ground & $\mathrm{kg}$ & $2,7172 \mathrm{E}-14$ \\
\hline Gravel, in ground & $\mathrm{kg}$ & $7,4657 \mathrm{E}-07$ \\
\hline Cinnabar, in ground & $\mathrm{kg}$ & $9,1391 \mathrm{E}-10$ \\
\hline Magnesite, $60 \%$ in crude ore, in ground & $\mathrm{kg}$ & $1,777 \mathrm{E}-15$ \\
\hline Nickel, $1.98 \%$ in silicates, $1.04 \%$ in crude ore, in ground & $\mathrm{kg}$ & $8,6679 \mathrm{E}-12$ \\
\hline Olivine, in ground & $\mathrm{kg}$ & $1,8983 \mathrm{E}-06$ \\
\hline Lead, $5.0 \%$ in sulfide, $\mathrm{Pb} 3.0 \%, \mathrm{Zn}, \mathrm{Ag}, \mathrm{Cd}$, In, in ground & $\mathrm{kg}$ & $8,3673 \mathrm{E}-07$ \\
\hline Phosphorus, $18 \%$ in apatite, $12 \%$ in crude ore, in ground & $\mathrm{kg}$ & $1,1267 \mathrm{E}-12$ \\
\hline Sylvite, $25 \%$ in sylvinite, in ground & $\mathrm{kg}$ & $2,1056 \mathrm{E}-07$ \\
\hline Sulfur, in ground & $\mathrm{kg}$ & 0,00002995 \\
\hline Sand, unspecified, in ground & $\mathrm{kg}$ & 0,000075193 \\
\hline Shale, in ground & $\mathrm{kg}$ & $8,1973 E-06$ \\
\hline Sodium chloride, in ground & $\mathrm{kg}$ & 0,00043368 \\
\hline Sodium nitrate, in ground & $\mathrm{kg}$ & $5,34 \mathrm{E}-15$ \\
\hline Zinc, $9.0 \%$ in sulfide, $\mathrm{Zn} 5.3 \%, \mathrm{~Pb}, \mathrm{Ag}, \mathrm{Cd}$, In, in ground & $\mathrm{kg}$ & $3,2662 E-08$ \\
\hline Water, unspecified natural origin $/ \mathrm{m}^{3}$ & $\mathrm{~m}^{3}$ & 0,0091389 \\
\hline Water, river & $\mathrm{m}^{3}$ & 0,00040809 \\
\hline Water, salt, ocean & $\mathrm{m}^{3}$ & 0,00020616 \\
\hline Water, well, in ground & $\mathrm{m}^{3}$ & $4,1245 \mathrm{E}-10$ \\
\hline Water, cooling, unspecified natural origin $/ \mathrm{m}^{3}$ & $\mathrm{~m}^{3}$ & 0,018514 \\
\hline \multicolumn{3}{|l|}{ Emissões para o Ar } \\
\hline Heat, waste & MJ & 58,157 \\
\hline Particulates, $>10$ um & $\mathrm{kg}$ & 0,00042791 \\
\hline Particulates, $>2.5 \mathrm{um}$, and $<10 \mathrm{um}$ & $\mathrm{kg}$ & 0,00057501 \\
\hline Particulates, $<2.5$ um & $\mathrm{kg}$ & 0,00033431 \\
\hline
\end{tabular}




\begin{tabular}{|c|c|c|}
\hline Entradas/saídas & Unidade & Quantidade \\
\hline Carbon monoxide, fossil & $\mathrm{kg}$ & 0,0034435 \\
\hline Carbon monoxide, biogenic & $\mathrm{kg}$ & 0,000006142 \\
\hline Carbon dioxide, fossil & $\mathrm{kg}$ & 3,4787 \\
\hline Carbon dioxide, biogenic & $\mathrm{kg}$ & 0,0062048 \\
\hline Sulfur dioxide & $\mathrm{kg}$ & 0,013421 \\
\hline Hydrogen sulfide & $\mathrm{kg}$ & 6,7952E-09 \\
\hline Nitrogen oxides & $\mathrm{kg}$ & 0,0076658 \\
\hline Ammonia & $\mathrm{kg}$ & $5,3215 \mathrm{E}-10$ \\
\hline Chlorine & $\mathrm{kg}$ & $2,4461 \mathrm{E}-08$ \\
\hline Hydrogen chloride & $\mathrm{kg}$ & 0,00014135 \\
\hline Fluorine & $\mathrm{kg}$ & $3,5445 \mathrm{E}-10$ \\
\hline Hydrogen fluoride & $\mathrm{kg}$ & $5,3067 E-06$ \\
\hline $\begin{array}{l}\text { NMVOC, non-methane volatile organic compounds, } \\
\text { unspecified origin }\end{array}$ & $\mathrm{kg}$ & 0,0092549 \\
\hline Aldehydes, unspecified & $\mathrm{kg}$ & $6,645 \mathrm{E}-15$ \\
\hline Lead & $\mathrm{kg}$ & $1,1184 \mathrm{E}-08$ \\
\hline Mercury & $\mathrm{kg}$ & $7,2528 \mathrm{E}-10$ \\
\hline Sulfate & $\mathrm{kg}$ & $5,393 E-15$ \\
\hline Dinitrogen monoxide & $\mathrm{kg}$ & $1,3131 \mathrm{E}-12$ \\
\hline Hydrogen & $\mathrm{kg}$ & 0,000061953 \\
\hline Ethane, 1,2-dichloro- & $\mathrm{kg}$ & $3,6332 \mathrm{E}-11$ \\
\hline Ethene, chloro- & $\mathrm{kg}$ & $8,1486 \mathrm{E}-10$ \\
\hline Hydrocarbons, chlorinated & $\mathrm{kg}$ & $2,1818 \mathrm{E}-08$ \\
\hline Methane, fossil & $\mathrm{kg}$ & 0,016034 \\
\hline Methane, biogenic & $\mathrm{kg}$ & 0,000028599 \\
\hline Hydrocarbons, aromatic & $\mathrm{kg}$ & 0,00020258 \\
\hline Hydrocarbons, aliphatic, alkanes, cyclic & $\mathrm{kg}$ & $1 \mathrm{E}-18$ \\
\hline Carbon disulfide & $\mathrm{kg}$ & $1,8611 \mathrm{E}-10$ \\
\hline Methane, dichloro-, HCC-30 & $\mathrm{kg}$ & $1,052 \mathrm{E}-10$ \\
\hline Copper & $\mathrm{kg}$ & 1,787E-09 \\
\hline Arsenic & $\mathrm{kg}$ & $4,1065 \mathrm{E}-10$ \\
\hline Cadmium & $\mathrm{kg}$ & $6,5473 \mathrm{E}-11$ \\
\hline Silver & $\mathrm{kg}$ & $4,1227 \mathrm{E}-11$ \\
\hline Zinc & $\mathrm{kg}$ & 1,4067E-09 \\
\hline Chromium & $\mathrm{kg}$ & $7,4706 \mathrm{E}-12$ \\
\hline Selenium & $\mathrm{kg}$ & $1,4279 \mathrm{E}-12$ \\
\hline Nickel & $\mathrm{kg}$ & $7,5141 \mathrm{E}-12$ \\
\hline Antimony & $\mathrm{kg}$ & $1,494 \mathrm{E}-15$ \\
\hline Ethene & $\mathrm{kg}$ & $2,4661 \mathrm{E}-06$ \\
\hline Benzene & $\mathrm{kg}$ & $9,4769 E-08$ \\
\hline
\end{tabular}




\begin{tabular}{|c|c|c|}
\hline Entradas/saídas & Unidade & Quantidade \\
\hline Propene & $\mathrm{kg}$ & $1,8267 \mathrm{E}-06$ \\
\hline \multicolumn{3}{|l|}{ Emissões para a Água } \\
\hline COD, Chemical Oxygen Demand & $\mathrm{kg}$ & 0,0007279 \\
\hline BOD5, Biological Oxygen Demand & $\mathrm{kg}$ & 0,00019882 \\
\hline Lead & $\mathrm{kg}$ & $2,1767 \mathrm{E}-10$ \\
\hline Iron, ion & $\mathrm{kg}$ & 8,8029E-09 \\
\hline Sodium, ion & $\mathrm{kg}$ & 0,000082141 \\
\hline Acidity, unspecified & $\mathrm{kg}$ & 0,000001816 \\
\hline Nitrate & $\mathrm{kg}$ & $2,2468 \mathrm{E}-06$ \\
\hline Mercury & $\mathrm{kg}$ & $2,0841 \mathrm{E}-11$ \\
\hline Ammonium, ion & $\mathrm{kg}$ & $3,2908 \mathrm{E}-06$ \\
\hline Chloride & $\mathrm{kg}$ & 0,00007233 \\
\hline Cyanide & $\mathrm{kg}$ & $1,9201 \mathrm{E}-11$ \\
\hline Fluoride & $\mathrm{kg}$ & $1,3175 \mathrm{E}-08$ \\
\hline Sulfide & $\mathrm{kg}$ & 7,3598E-09 \\
\hline Hydrocarbons, unspecified & $\mathrm{kg}$ & 0,000018074 \\
\hline Suspended solids, unspecified & $\mathrm{kg}$ & 0,0002519 \\
\hline Oils, unspecified & $\mathrm{kg}$ & 0,000012153 \\
\hline Chlorinated solvents, unspecified & $\mathrm{kg}$ & 6,7197E-09 \\
\hline Chlorine & $\mathrm{kg}$ & $8,6019 \mathrm{E}-10$ \\
\hline Phenol & $\mathrm{kg}$ & 8,6073E-07 \\
\hline Solved solids & $\mathrm{kg}$ & 0,000024311 \\
\hline Phosphorus & $\mathrm{kg}$ & $7,3214 \mathrm{E}-08$ \\
\hline Nitrogen & $\mathrm{kg}$ & $1,0783 E-06$ \\
\hline Sulfate & $\mathrm{kg}$ & 0,00036864 \\
\hline Ethane, 1,2-dichloro- & $\mathrm{kg}$ & $8,2843 E-13$ \\
\hline Ethene, chloro- & $\mathrm{kg}$ & $1,5132 \mathrm{E}-11$ \\
\hline Potassium, ion & $\mathrm{kg}$ & $6,6204 \mathrm{E}-09$ \\
\hline Calcium, ion & $\mathrm{kg}$ & $5,2847 \mathrm{E}-07$ \\
\hline Magnesium & $\mathrm{kg}$ & $2,5232 \mathrm{E}-10$ \\
\hline Chromium, ion & $\mathrm{kg}$ & $4,9528 \mathrm{E}-13$ \\
\hline Chlorate & $\mathrm{kg}$ & $1,1215 \mathrm{E}-07$ \\
\hline Bromate & $\mathrm{kg}$ & $1,9233 \mathrm{E}-10$ \\
\hline TOC, Total Organic Carbon & $\mathrm{kg}$ & 0,000016778 \\
\hline AOX, Adsorbable Organic Halogen as $\mathrm{Cl}$ & $\mathrm{kg}$ & $1,8046 \mathrm{E}-12$ \\
\hline Aluminium & $\mathrm{kg}$ & $2,9567 \mathrm{E}-07$ \\
\hline Zinc, ion & $\mathrm{kg}$ & 2,8956E-09 \\
\hline Copper, ion & $\mathrm{kg}$ & $4,8435 E-09$ \\
\hline Nickel, ion & $\mathrm{kg}$ & $4,6683 E-10$ \\
\hline
\end{tabular}




\begin{tabular}{|c|c|c|}
\hline Entradas/saídas & Unidade & Quantidade \\
\hline Carbonate & $\mathrm{kg}$ & 0,000045259 \\
\hline Arsenic, ion & $\mathrm{kg}$ & $2,0758 \mathrm{E}-10$ \\
\hline Cadmium, ion & $\mathrm{kg}$ & $4,3852 \mathrm{E}-13$ \\
\hline Manganese & $\mathrm{kg}$ & $1,8423 \mathrm{E}-14$ \\
\hline Tin, ion & $\mathrm{kg}$ & $1,44 \mathrm{E}-16$ \\
\hline Strontium & $\mathrm{kg}$ & $1,1954 \mathrm{E}-11$ \\
\hline \multicolumn{3}{|l|}{ Resíduos Sólidos para tratamento } \\
\hline Disposal, facilities, chemical production/RER $U$ & $\mathrm{~kg}$ & $4,7955 E-10$ \\
\hline $\begin{array}{l}\text { Disposal, tailings from hard coal milling, in } \\
\text { impoundment/GLO U }\end{array}$ & $\mathrm{kg}$ & 0,00031615 \\
\hline Disposal, spoil from coal mining, in surface landfill/GLO U & $\mathrm{kg}$ & 0,049759 \\
\hline $\begin{array}{l}\text { Disposal, municipal solid waste, } 22.9 \% \text { water, to } \\
\text { municipal incineration/CH U }\end{array}$ & $\mathrm{kg}$ & 0,011365 \\
\hline $\begin{array}{l}\text { Disposal, average incineration residue, } 0 \% \text { water, to } \\
\text { residual material landfill/CH U }\end{array}$ & $\mathrm{kg}$ & 0,017509 \\
\hline $\begin{array}{l}\text { Disposal, wood untreated, } 20 \% \text { water, to municipal } \\
\text { incineration/CH U }\end{array}$ & $\mathrm{kg}$ & $6,571 \mathrm{E}-08$ \\
\hline $\begin{array}{l}\text { Disposal, plastics, mixture, } 15.3 \% \text { water, to municipal } \\
\text { incineration/CH U }\end{array}$ & $\mathrm{kg}$ & $9,9754 \mathrm{E}-07$ \\
\hline $\begin{array}{l}\text { Disposal, hazardous waste, } 25 \% \text { water, to hazardous } \\
\text { waste incineration/ } \mathrm{CH} \mathrm{U}\end{array}$ & $\mathrm{kg}$ & 0,007806 \\
\hline
\end{tabular}

\subsubsection{Subsistema Produção de Poliestireno}

O subsistema de produção de poliestireno contemplou as seguintes definições de escopo:

a. Fonte de dados: dados secundários modelados para quantificação dos fluxos de matéria e energia deste processo.

b. Cobertura Temporal: A matriz energética do processo está baseada na composição do ano de 2011, segundo o Balanço Energético Nacional (EPE, 2012). Todas as demais coberturas contempladas estão relacionadas aos bancos de dados utilizados.

c. Cobertura Geográfica: estados de São Paulo e Rio Grande do Sul.

d. Critério de exclusão: mássico, sempre que a corrente representasse menos de $1 \%$ em massa dos fluxos de entrada ou saída da unidade de produção. 


\subsubsection{Cobertura Tecnológica da produção de poliestireno}

Conforme apresentado no capítulo de revisão de literatura, a rota tecnológica para a produção de poliestireno comumente praticada no Brasil é composta pelas seguintes etapas: produção de etilbenzeno a partir de alquilação de benzeno com eteno; manufatura de monômero de estireno por meio de desidrogenação catalítica do etilbenzeno em presença de vapor d'água; e, polimerização de estireno a partir de reatores contínuos agitados.

Estes mesmos processos de manufatura foram utilizados para compor este subsistema, por meio do uso de elementos dos bancos de dados do Ecoinvent.

É válido ressaltar, nesse âmbito, que foram realizados ajustes nestes inventários para a inserção da matriz energética brasileira e consumo de água no processo. No último caso, considerou-se que as perdas de água de processo, água para produção de vapor e make-up de água de resfriamento, é equivalente a $3 \%$ em massa da quantidade de água requerida para estas atividades.

\subsection{Unidade complementar de vapor d'água}

Para que todas as etapas produtivas mencionadas no item anterior ocorram, faz-se necessário o uso de vapor d'água. Assim, foi incorporado a este subsistema o inventário do ciclo de vida referente ao funcionamento de um boiler a gás, obtido junto à base de dados do Ecoinvent. Os fluxos de entrada e saída deste processo elementar estão apresentados na Tabela 40.

Tabela 40: Inventário do Ciclo de Vida da unidade de produção de vapor - boiler à gás

\begin{tabular}{lcc}
\hline Entradas/saídas & Unidade & Quantidade \\
\hline Entradas de material e energia & $\mathrm{MJ}$ & \\
$\quad$ Natural gas, burned in boiler - BR - MDL & $\mathrm{kWh}$ & 0,00278 \\
Electricity - medium voltage, at grid 2012/ BR & $\mathrm{p}$ & $6,6 \mathrm{E}-07$ \\
Gas boiler/RER/I U & & \\
Emissões para o ar & $\mathrm{MJ}$ & 1,11 \\
$\quad$ Heat, waste & $\mathrm{kg}$ & $1 \mathrm{E}-09$ \\
Acetaldehyde & $\mathrm{kg}$ & $1 \mathrm{E}-11$ \\
Benzo(a)pyrene & \\
\hline
\end{tabular}




\begin{tabular}{lcc}
\hline Entradas/saídas & Unidade & Quantidade \\
\hline Benzene & $\mathrm{kg}$ & $4 \mathrm{E}-07$ \\
Butane & $\mathrm{kg}$ & $7 \mathrm{E}-07$ \\
Methane, fossil & $\mathrm{kg}$ & 0,000002 \\
Carbon monoxide, fossil & $\mathrm{kg}$ & $7,8 \mathrm{E}-06$ \\
Carbon dioxide, fossil & $\mathrm{kg}$ & 0,056 \\
Acetic acid & $\mathrm{kg}$ & $1,5 \mathrm{E}-07$ \\
Formaldehyde & $\mathrm{kg}$ & $1 \mathrm{E}-07$ \\
Mercury & $\mathrm{kg}$ & $3 \mathrm{E}-11$ \\
Dinitrogen monoxide & $\mathrm{kg}$ & $5 \mathrm{E}-07$ \\
Nitrogen oxides & $\mathrm{kg}$ & $1,45 \mathrm{E}-05$ \\
PAH, polycyclic aromatic hydrocarbons & $\mathrm{kg}$ & $1 \mathrm{E}-08$ \\
Particulates, $<2.5$ um & $\mathrm{kg}$ & $1 \mathrm{E}-07$ \\
Pentane & $\mathrm{kg}$ & $1,2 \mathrm{E}-06$ \\
Propane & $\mathrm{kg}$ & $2 \mathrm{E}-07$ \\
Propionic acid & $\mathrm{kg}$ & $2 \mathrm{E}-08$ \\
Sulfur dioxide & $\mathrm{kg}$ & $5,5 \mathrm{E}-07$ \\
Dioxin, 2,3,7,8 Tetrachlorodibenzo-p- & $\mathrm{kg}$ & $3 \mathrm{E}-17$ \\
Toluene & $\mathrm{kg}$ & $2 \mathrm{E}-07$ \\
\hline
\end{tabular}

\subsubsection{Emissões para a atmosfera}

As emissões gasosas oriundas da planta de poliestireno são resultantes, fundamentalmente, do processo de combustão de gás e alívios das válvulas de emergência e do processo. Os valores destes fluxos foram obtidos juntos aos bancos de dados adotados.

\subsubsection{Emissões para o solo}

As emissões para o solo referentes à produção de poliestireno são compostas pelos rejeitos esporádicos gerados durante o processo, tais como catalisadores, aluminas e borras oleosas.

Apesar de existentes, todos os rejeitos contemplados no processo não totalizam mais que $1 \%$ em massa dos fluxos de entrada e saída do subsistema. Por esta razão, tais resíduos foram excluídos do inventário do ciclo de vida. 


\subsubsection{Emissões para a água}

A carga de poluentes lançada em meio aquoso diz respeito àquela originária dos efluentes líquidos do subsistema de produção de poliestireno. Neste âmbito, foram avaliadas as seguintes contribuições de emissão para a água:

- DBO - Demanda Bioquímica de Oxigênio

-DQO - Demanda Química de Oxigênio

- SST - Sólidos Suspensos Totais

- Fósforo (dissolvido no efluente)

- TKN - "Total Kjeldahl Nitrogen" ou Nitrogênio contido no efluente na forma de compostos nitrogenados.

As características dos Efluentes Hídricos de saída de cada etapa de processo da planta de poliestireno foram quantificadas por meio de dados secundários constantes no Ecoinvent.

\subsubsection{Banco de Dados}

O desenvolvimento do subsistema de produção de poliestireno GPPS e HIPS contou com adoção de bancos de dados contidos na base do Ecoinvent, selecionados de modo a representar o inventário de insumos auxiliares ao processo. A Tabela 41 apresenta os elementos e os respectivos bancos de dados utilizados.

Tabela 41: Bancos de dados do Ecoinvent adotados na produção de poliestireno

\begin{tabular}{ll}
\hline Nome & \multicolumn{1}{c}{ Elemento do Ecoinvent } \\
\hline Água & Tap water, at user/RER U \\
\hline Energia térmica & Heat, natural gas, at industrial furnace $>100 \mathrm{~kW} / R E R U$ \\
\hline Polibutadieno PB & Polybutadiene, at plant/RERU \\
\hline Polibutadieno SBS & Polybutadiene, at plant/RERU \\
\hline Transporte rodoviário & Transport, lorry 3.5-7.5t, EURO4/RER U \\
Transporte oceânico & Transport, lorry 3.5-7.5t, EURO3/RERU \\
\hline Poliestireno & Transoceanic freight ship/OCE U \\
\hline
\end{tabular}


Todos os demais componentes necessários para o subsistema de produção de poliestireno e que não compõe a lista mencionada na Tabela 41, foram assim excluídos por representar fluxo de massa inferior a $1 \%$ do total contabilizado para o processo.

\subsubsection{Inventário do Ciclo de Vida do GPPS e HIPS}

A Tabela 42 descreve o ICV da produção de 1t. GPPS de acordo com as condições praticadas no país para esse processamento.

Tabela 42: Inventário da produção de 1 t. GPPS

\begin{tabular}{|c|c|c|}
\hline Entradas/saídas & Unidade & Quantidade \\
\hline \multicolumn{3}{|l|}{ Produtos } \\
\hline Poliestireno Cristal GPPS, at plant/BR & ton & 1,0 \\
\hline \multicolumn{3}{|l|}{ Entradas } \\
\hline Benzeno, at transportation/BR & ton & 0,2894 \\
\hline Eteno, at transportation/BR & ton & 0,8401 \\
\hline Heavy fuel oil PS, at plant/BR & ton & 0,0214 \\
\hline Heavy fuel oil SM, at plant/BR & ton & 0,0793 \\
\hline N2 liquido Braskem, at transportation/BR & $\mathrm{m}^{3}$ & 6,8184 \\
\hline Oleo mineral, at transportation/BR & ton & 0,0209 \\
\hline Tap water, at user - BR & ton & 10,4252 \\
\hline Electricity - medium voltage, at grid 2012/ BR & $\mathrm{kWh}$ & 332,3715 \\
\hline Heat, natural gas, at industrial furnace $>100 \mathrm{~kW} / \mathrm{RER} U$ & MJ & 10247,4427 \\
\hline \multicolumn{3}{|l|}{ Emissões para o Ar } \\
\hline Carbon dioxide & $\mathrm{mg}$ & 0,2467 \\
\hline Carbon dioxide, fossil & $\mathrm{mg}$ & 0,2055 \\
\hline Carbon monoxide & $\mu \mathrm{g}$ & 0,3099 \\
\hline Dinitrogen monoxide & $\mu g$ & 0,0117 \\
\hline Methane, fossil & $\mathrm{mg}$ & 0,0019 \\
\hline Nitrogen dioxide & $\mathrm{mg}$ & 0,0005 \\
\hline $\begin{array}{l}\text { NMVOC, non-methane volatile organic compounds, } \\
\text { unspecified origin }\end{array}$ & $\mu \mathrm{g}$ & 0,4640 \\
\hline Particulates, $<10$ um (stationary) & $\mu \mathrm{g}$ & 0,0596 \\
\hline Sulfur dioxide & $\mu \mathrm{g}$ & 0,0655 \\
\hline VOC, volatile organic compounds & $\mathrm{mg}$ & 0,0024 \\
\hline \multicolumn{3}{|l|}{ Emissões para a Água } \\
\hline BOD5, Biological Oxygen Demand & $\mathrm{mg}$ & 0,2144 \\
\hline
\end{tabular}




\begin{tabular}{ccc}
\hline Entradas/saídas & Unidade & Quantidade \\
\hline COD, Chemical Oxygen Demand & $\mathrm{mg}$ & 4,2799 \\
Nitrogen, total & $\mathrm{mg}$ & 0,6733 \\
Phosphorus, total & $\mathrm{mg}$ & 0,8776 \\
Suspended solids, unspecified & $\mathrm{mg}$ & 7,9024 \\
\hline
\end{tabular}

Seguindo uma abordagem semelhante àquela que a antecede a Tabela 43 descreve o ICV da produção de 1t. HIPS.

Tabela 43: Inventário da produção de 1 tonelada de HIPS

\begin{tabular}{|c|c|c|}
\hline Entradas/saídas & Unidade & Quantidade \\
\hline \multicolumn{3}{|l|}{ Produtos } \\
\hline Poliestireno Cristal HIPS, at plant/BR & ton & 1,0 \\
\hline \multicolumn{3}{|l|}{ Entradas } \\
\hline Benzeno, at transportation/BR & ton & 0,2677 \\
\hline Eteno, at transportation/BR & ton & 0,7771 \\
\hline Heavy fuel oil PS, at plant/BR & ton & 0,0150 \\
\hline Heavy fuel oil SM, at plant/BR & ton & 0,0733 \\
\hline N2 liquido Braskem, at transportation/BR & $\mathrm{m}^{3}$ & 6,5803 \\
\hline Oleo mineral, at transportation/BR & ton & 0,0230 \\
\hline Polybutadiene PE, at transportation/BR & ton & 0,0650 \\
\hline Polybutadiene SP, at transportation/BR & ton & 0,0136 \\
\hline Tap water, at user - BR & ton & 9,7459 \\
\hline Electricity - medium voltage, at grid 2012/ BR & kWh & 272,5911 \\
\hline Heat, natural gas, at industrial furnace $>100 \mathrm{~kW} / \mathrm{RER} U$ & MJ & 9313,2334 \\
\hline \multicolumn{3}{|l|}{ Emissões para o Ar } \\
\hline Carbon dioxide & $\mathrm{mg}$ & 0,2329 \\
\hline Carbon dioxide, fossil & $\mathrm{mg}$ & 0,1946 \\
\hline Carbon monoxide & $\mu \mathrm{g}$ & 0,2876 \\
\hline Dinitrogen monoxide & $\mu \mathrm{g}$ & 0,0110 \\
\hline Methane, fossil & $\mathrm{mg}$ & 0,0017 \\
\hline Nitrogen dioxide & $\mu \mathrm{g}$ & 0,4963 \\
\hline $\begin{array}{l}\text { NMVOC, non-methane volatile organic compounds, } \\
\text { unspecified origin }\end{array}$ & $\mu \mathrm{g}$ & 0,4298 \\
\hline Particulates, $<10$ um (stationary) & $\mu \mathrm{g}$ & 0,0559 \\
\hline Sulfur dioxide & $\mu \mathrm{g}$ & 0,0625 \\
\hline VOC, volatile organic compounds & $\mathrm{mg}$ & 0,0022 \\
\hline \multicolumn{3}{|l|}{ Emissões para a Água } \\
\hline BOD5, Biological Oxygen Demand & 0,2002 & $\mathrm{mg}$ \\
\hline COD, Chemical Oxygen Demand & 3,9958 & $\mathrm{mg}$ \\
\hline
\end{tabular}




\begin{tabular}{ccc}
\hline Entradas/saídas & Unidade & Quantidade \\
\hline Nitrogen, total & 0,6286 & $\mathrm{mg}$ \\
Phosphorus, total & 0,8194 & $\mathrm{mg}$ \\
Suspended solids, unspecified & 7,3777 & $\mathrm{mg}$ \\
\hline
\end{tabular}

\subsubsection{Subsistema cultivo de cana-de-açúcar}

O subsistema cultivo de cana-de-açúcar trata-se da primeira etapa de obtenção de eteno renovável, a qual dará origem ao poliestireno de fonte parcialmente renovável. Para esse processo elementar, os dados referentes aos fluxos de matéria e energia foram importados do estudo realizado por Sugawara (2012).

Isto posto, seguem abaixo as características de definição de escopo para este subsistema:

a. Fonte de dados: secundários, obtidos em Sugawara (2012).

b. Cobertura Temporal: período de 2008 a 2011 no que tange às características de produtividade de cana-de-açúcar em território nacional. Todas as demais coberturas contempladas estão relacionadas aos bancos de dados utilizados.

c. Cobertura Geográfica: estado de São Paulo.

d. Cobertura Tecnológica: composição entre os mecanismos de colheita e plantio manuais e mecanizados.

\subsubsection{1 Área, produtividade e produção de cana-de-açúcar}

A fim de minimizar os desvios da produção agrícola decorrentes de variações climáticas, a cobertura temporal analisada para a identificação da área colhida, produtividade e produção de cana-de-açúcar em São Paulo abarcou os anos de 2008 a 2011. Para este período, segundo a SUGAWARA (2012), foram calculados os seguintes valores médios:

- Área Colhida: 4.012,12 mil ha;

- Produtividade: 86,5 tha; e, 
- Produção: 345 milhões de toneladas.

\subsubsection{2 Área de Plantio e consumo de mudas}

Conforme descrito na revisão bibliográfica, o plantio de mudas de cana-de-açúcar ocorre, atualmente, em áreas onde já existe produção agrícola ou em função da abertura de novas áreas. Segundo dados do CONAB (2011), São Paulo foi o estado em que houve o maior incremento de área cultivada para a produção de cana, alcançando um aumento médio de 12\% para a Safra de 2009/2010.

Desta área, $22,8 \%$ da lavoura foi destinada à produção de mudas, visto a necessidade de replantio para os casos em que o mesmo exemplar sofreu até cinco cortes ao longo de seis anos.

O plantio realizado em solo paulista ocorreu tanto por ação semi-mecanizada abertura e aterramento de sulco mecanizado; e distribuição das mudas, manual quanto via técnicas inteiramente mecanizadas. Na Tabela 44 estão apresentados os dados adotados para o levantamento dos aspectos ambientais deste estudo.

Tabela 44: Caracterização do esquema de plantio adotado no estudo (SUGAWARA, 2012).

\begin{tabular}{lc}
\hline \multicolumn{1}{c}{ Dado } & Quantidade \\
\hline Plantio em nova área de expansão (\%) & 12,0 \\
\hline Plantio em área de reforma (\%) & 88,0 \\
\hline Plantio semi-mecanizado (\%) & 90,0 \\
\hline Plantio integralmente mecanizado (\%) & 10,0 \\
\hline Consumo de mudas para o plantio semi-mecanizado (t/ha) & 12,0 \\
\hline Consumo de mudas para o plantio integralmente mecanizado (t/ha) & 20,0 \\
\hline
\end{tabular}

\subsubsection{Aplicação de resíduos industriais no campo}

Faz parte do avanço tecnológico do cultivo de cana, o uso de resíduos industriais da usina sucroalcooleira.

Este material, composto pode torta de filtro, vinhaça e cinzas, visa suprir parcialmente a demanda de nutrientes do solo da lavoura, substituindo outras fontes de matériaprima. 
No trabalho de Sugawara (2012), a área coberta com esses resíduos e o percentual desta em relação à área total cultivada foi estimada em:

- Torta de filtro: $5.000 \mathrm{~kg} /\left(\mathrm{ha}^{*}\right.$ ano) e $11,2 \%$ da área total;

- Vinhaça: 100 kg/(ha*ano) e $51,8 \%$ da área total; e,

- Cinzas: $5.000 \mathrm{~kg} /\left(\mathrm{ha}^{*}\right.$ ano) e $8,4 \%$ da área total.

\subsubsection{Colheita}

Assim como o plantio, a colheita de cana de açúcar pode ocorrer a partir de sistemas manuais ou mecânicos e, consequentemente, com ou sem queima prévia da plantação. O estado de São Paulo, de acordo com a CONAB (2011), possui o maior índice de colheita mecanizada, de tal forma que a participação de cada um desses sistemas no desenvolvimento do estudo resultou na composição apresentada na Tabela 45.

Tabela 45: Caracterização do esquema de colheita adotada no estudo (SUGAWARA, 2012).

\begin{tabular}{lc}
\hline \multicolumn{1}{c}{ Dado } & Quantidade \\
\hline Colheita manual (\%) & 36,4 \\
\hline Colheita mecanizada (\%) & 63,6 \\
Queima prévia em área de colheita manual (\%) & 94,9 \\
\hline Queima prévia em área de colheita mecanizada (\%) & 25,6 \\
\hline
\end{tabular}

A produção de palha decorrente da colheita é de aproximadamente $140 \mathrm{~kg}$ (base seca) por tonelada de cana-de-açúcar (HASSUANI ET AL., 2005 apud SUGAWARA, 2012). Tendo em vista esta taxa de geração de palha e a produtividade de cana-de-açúcar em São Paulo, tem-se que 12,1 toneladas de palha são produzidas por hectare. Assim, considerando os percentuais de colheita e seus respectivos índices de queima prévia, é possível concluir que para cada hectare exatas 6,14 t. palha são queimadas, enquanto que o restante é deixado no campo.

\subsubsection{Consumo de calcário e gesso}

A adoção de calcário e gesso tem por objetivo neutralizar a acidez do solo no plantio de novas mudas de cana. Por este motivo, esses insumos são aplicados somente em 
$22,8 \%$ da área do canavial. Os consumos de calcário e gesso utilizados no estudo desenvolvido por Sugawara (2012) foram de $2.000 \mathrm{~kg} /\left(\right.$ ha*ano) e $1.000 \mathrm{~kg} /\left(\mathrm{ha}^{*}\right.$ ano), respectivamente.

\subsubsection{Consumo de fertilizantes minerais}

O consumo de fertilizantes mineiras nas plantações de cana-de-açúcar é resultante da necessidade de complementação de nutrientes no solo, os quais não foram suficientemente supridos pelos resíduos das usinas sucroalcooleiras.

As quantidades necessárias de nitrogênio, pentóxido de fósforo e óxido de potássio para cada estágio da cana-de-açúcar está apresentada na Tabela 46, enquanto que a Tabela 47 demonstra o tipo e quantidade de fertilizantes aplicados neste mesmo cultivo.

Tabela 46: Teor de nutrientes recomendado nos diferentes estágios da cana (SUGAWARA, 2012).

\begin{tabular}{lccc}
\hline \multicolumn{1}{c}{ Tipo de cana } & \multicolumn{3}{c}{ Quantidade $\left(\mathrm{kg} \cdot \mathrm{ha}^{-1}\right.$.ano-1 } \\
& $\mathbf{N}$ & $\mathbf{P}_{\mathbf{2}} \mathbf{O}_{\mathbf{5}}$ & $\mathbf{K}_{\mathbf{2}} \mathbf{O}$ \\
\hline Planta cana & 30 & 150 & 150 \\
Soqueira com queima prévia & 100 & 0 & 150 \\
Ratoon sem queima prévia & 100 & 0 & 100 \\
Soqueira com aplicação de vinhaça & 67.5 & 0 & 0 \\
\hline
\end{tabular}

Tabela 47: Tipo e quantidade de fertilizantes aplicados (SUGAWARA, 2012).

\begin{tabular}{lcc}
\hline \multicolumn{1}{c}{ Tipo de fertilizante mineral } & Unidade & Quantidade \\
\hline Amônia & $\mathrm{kg} \cdot \mathrm{ha}^{-1} \cdot \mathrm{ano}^{-1}$ & 8,12 \\
\hline Uréia & $\mathrm{kg} \cdot \mathrm{ha}^{-1} \cdot \mathrm{ano}^{-1}$ & 135 \\
\hline Nitrato de amônio & $\mathrm{kg} \cdot \mathrm{ha}^{-1} \cdot \mathrm{ano}^{-1}$ & 31,3 \\
\hline Fosfato de monoamônio (MAP) & $\mathrm{kg} \cdot \mathrm{ha}^{-1} \cdot \mathrm{ano}^{-1}$ & 6,27 \\
\hline Superfostato simples (SSP) & $\mathrm{kg} \cdot \mathrm{ha}^{-1} \cdot \mathrm{ano}^{-1}$ & 186 \\
\hline Cloreto de potássio (KCl) & $\mathrm{kg} \cdot \mathrm{ha}^{-1} \cdot \mathrm{ano}^{-1}$ & 115 \\
\hline
\end{tabular}

\subsubsection{Consumo de Pesticidas}

As mudas provenientes de canaviais e a própria lavoura são tratadas contra pragas e doenças a partir do uso de compostos por fungicidas e inseticidas. Os tipos e as 
dosagens de cada defensivo no cultivo da cana-de-açúcar estão discriminados na Tabela 48.

Tabela 48: Teor de nutrientes recomendado nos diferentes estágios da cana (SUGAWARA, 2012).

\begin{tabular}{|c|c|c|c|c|}
\hline Tipo de fertilizante mineral & Plantio & Reforma & Planta cana & Soqueira \\
\hline Fipronil (kg.ha-1 $\left.\cdot \mathrm{ano}^{-1}\right)$ & 0,20 & - & - & - \\
\hline Carbofuran (kg.ha-1 $\cdot$ ano $\left.^{-1}\right)$ & 2,1 & - & - & - \\
\hline Glifosato (kg.ha-1 ano $\left.^{-1}\right)$ & - & 1,3 & - & - \\
\hline Tebuthiuron (kg.ha-1 ano $\left.^{-1}\right)$ & - & - & 0,50 & - \\
\hline Hexazinona $\left(\mathrm{kg} \cdot \mathrm{ha}^{-1} \cdot \mathrm{ano}^{-1}\right)$ & - & - & 0,14 & - \\
\hline Diuron $\left(\mathrm{kg} \cdot \mathrm{ha}^{-1} \cdot \mathrm{ano}^{-1}\right)$ & - & - & 0,49 & - \\
\hline Imazapique (kg.ha-1 .ano $\left.^{-1}\right)$ & - & - & - & 0,18 \\
\hline Ethyl Trinexapaque $\left(\mathrm{kg} \cdot \mathrm{ha}^{-1} \cdot\right.$ ano $\left.^{-1}\right)$ & - & - & 0,13 & 0,13 \\
\hline
\end{tabular}

\subsubsection{Equipamentos e consumo de Óleo Diesel}

O plantio e colheita semi-mecanizados ou mecanizados fazem uso maquinários que consumem combustível para a realização de atividades como: pré-plantio, preparação do solo, plantio, cultivo e colheita. A fim de contabilizar os aspectos relacionados a esta atividade, foram adotadas as taxas de consumo de óleo diesel apresentadas na Tabela 49.

Tabela 49: Consumo de óleo diesel por grupo de processos agrícolas da cana (FNP, 2010 apud SUGAWARA, 2012).

\begin{tabular}{lcc}
\hline \multicolumn{1}{r}{ Processo Agrícola } & Unidade & Quantidade de óleo diesel \\
\hline Pré-plantio e preparo do solo & I.ha- ${ }^{-1} \cdot a n o^{-1}$ & 25,2 \\
\hline Plantio & I.ha ${ }^{-1} \cdot \mathrm{ano}^{-1}$ & 15,2 \\
\hline Cultivo & I.ha ${ }^{-1} \cdot \mathrm{ano}^{-1}$ & 37,6 \\
\hline Colheita & I.ha- ${ }^{-1} \cdot \mathrm{ano}^{-1}$ & 150,9 \\
\hline
\end{tabular}




\subsubsection{Captura de Dióxido de Carbono e emissões atmosféricas}

A retirada de gás carbônico da atmosfera para a constituição de matéria vegetal faz parte do desenvolvimento do inventário do subsistema de cultivo de cana, assim como as emissões decorrentes do processo de transformação da matéria orgânica em insumos. Desta forma, para fins de modelagem, foi considerado que para a formação de 1 t. de cana-de-açúcar são necessários 653 kg de $\mathrm{CO}_{2}$ (CGEE, 2009).

Já as emissões atmosféricas resultantes deste processo foram estimadas de acordo com a fonte geradora, contempladas por: queima de combustíveis; oxidação de fertilizantes, calcário e resíduos industriais, revolvimento do solo e queima do canavial.

\subsection{Emissões decorrentes da queima de óleo diesel}

Para a quantificação dos poluentes atmosféricos derivados da queima de óleo diesel, foram adotados os fatores de emissão calculados por Nemecek e Kaji (2007). Os valores empregados por Sugawara (2012), e aproveitados também neste trabalho, aparecem na Tabela 50.

Tabela 50: Fatores de emissão para a queima de óleo diesel em maquinários agrícolas (NEMECEK e KAJI, 2007 apud SUGAWARA, 2012).

\begin{tabular}{llc}
\hline \multicolumn{1}{c}{ Emissões } & Unidade & Quantidade \\
\hline Carbon dioxide (fossil) & $\mathrm{g} / \mathrm{kg}$ diesel & $3,12 * 10^{3}$ \\
\hline Methane (fossil) & $\mathrm{g} / \mathrm{kg}$ diesel & $1,29 * 10^{-1}$ \\
\hline Dinitrogen monoxide & $\mathrm{g} / \mathrm{kg}$ diesel & $1,20 * 10^{-1}$ \\
\hline Ammonia & $\mathrm{g} / \mathrm{kg}$ diesel & $2,00 * 10^{-2}$ \\
\hline Sulfur dioxide & $\mathrm{g} / \mathrm{kg}$ diesel & 1,01 \\
\hline Benzene & $\mathrm{g} / \mathrm{kg}$ diesel & $7,30 * 10^{-3}$ \\
\hline Cadmium & $\mathrm{g} / \mathrm{kg}$ diesel & $1,00 * 10^{-5}$ \\
\hline Chromium & $\mathrm{g} / \mathrm{kg}$ diesel & $5,00 * 10^{-5}$ \\
\hline Copper & $\mathrm{g} / \mathrm{kg}$ diesel & $1,70 * 10^{-3}$ \\
\hline Nickel & $\mathrm{g} / \mathrm{kg}$ diesel & $7,00 * 10^{-5}$ \\
\hline Selenium & $\mathrm{g} / \mathrm{kg}$ diesel & $1,00 * 10^{-5}$ \\
\hline Zinc & $\mathrm{g} / \mathrm{kg}$ diesel & $1,00 * 10^{-3}$ \\
\hline Benzo(a)pyrene & $\mathrm{g} / \mathrm{kg}$ diesel & $3,00 * 10^{-5}$ \\
\hline Polycyclic Aromatic Hydrocarbons & $\mathrm{g} / \mathrm{kg}$ diesel & $3,29 * 10^{-3}$ \\
\hline Hydrocarbons & $\mathrm{g} / \mathrm{kg}$ diesel & $3,00 * 10^{0}$ \\
\hline Carbon monoxide (fossil) & $\mathrm{g} / \mathrm{kg}$ diesel & $5,40 * 10^{0}$ \\
\hline Nitrogen oxides & $\mathrm{g} / \mathrm{kg}$ diesel & $4,25 * 10^{1}$ \\
\hline
\end{tabular}




\subsection{Emissões de fertilizantes}

O uso de fertilizantes aporta no cultivo de cana a emissão de compostos nitrogenados, seja em virtude de reações naturais ocasionadas por bactérias nitrificantes, seja pela volatilização do próprio fertilizante em decorrência do método de aplicação. Com o intuito de quantificar tais emissões, foram adotadas as Equações 10 e 11.

$$
\mathrm{NH}_{3}=\frac{\sum N_{\text {fert }} * F E_{\text {fert }} * 17 / 14}{\text { Produtividade }}
$$

Onde:

$\mathrm{NH}_{3}$ : emissão de $\mathrm{NH}_{3}$ do uso de fertilizantes minerais [ $\mathrm{kg} \mathrm{NH} / 3 \mathrm{~kg}$ cana];

$N_{\text {fert: }}$ entrada de $\mathrm{N}$ a partir de fertilizante mineral [kg N/ha] (ver Tabela 50);

FE fert: os fatores de emissão por tipo de fertilizante, de acordo com a EPFL (2011) são de: $3 \%$ para amônia; $15 \%$ para uréia; $2 \%$ para o nitrato de amônio; e $4 \%$ para o MAP. 17/14: fator de conversão de $\mathrm{N}$ para $\mathrm{NH}_{3}$; e

Produtividade: produção de cana por hectare [kg cana/ha]

$$
N_{2} \mathrm{O}=\frac{\frac{44}{28} *\left\{0,01 *\left(N_{\text {total }}+N_{\text {res.veg. }}\right)+0,01 * \frac{14}{17} * N H_{3}+0,0075 * \frac{14}{62} * N O_{3-}\right\}}{\text { Produtividade }}
$$

Onde:

$\mathrm{N}_{2} \mathrm{O}$ : emissão de $\mathrm{N}_{2} \mathrm{O}$ [kg N $\mathrm{k}_{2} \mathrm{O} / \mathrm{kg}$ de cana];

44/28: fator de conversão de $\mathrm{N}$ para $\mathrm{N}_{2} \mathrm{O}$;

$\mathrm{N}_{\text {total: }}$ entrada de $\mathrm{N}$ a partir de fertilizante mineral [kg N/ha] (ver Tabela 50);

Nres.veg.: nitrogênio contido no resto de palha [kg N/ha]. Segundo Franco (2008), equivale a $0,477 \%$ em base seca de massa.

17/14: fator de conversão de $\mathrm{N}$ para $\mathrm{NH}_{3}$;

$\mathrm{NH}_{3}$ : emissão de $\mathrm{NH}_{3}$ do uso de fertilizantes minerais [ $\mathrm{kg} \mathrm{NH}_{3} /$ ha]. Ver Equação 9;

14/62: fator de conversão de $\mathrm{N}$ para $\mathrm{NO}_{3}{ }^{-}$;

$\mathrm{NO}_{3}$ : perdas de nitrogênio na forma de nitrato [ $\mathrm{Kg} \mathrm{NO}_{3}-/$ ha].

Produtividade: produção de cana por hectare [kg cana/ha]. 


\subsection{Emissões de calcário}

Conforme estudos realizados pelo Painel Intergovernamental de Mudanças Climáticas (IPCC, 2006 apud SUGAWARA, 2012), 13\% em massa do calcário utilizado em cultivo agrícola são lançados para a atmosfera em forma de carbono. Assim, a massa de dióxido de carbono emitido é o resultado da multiplicação da quantidade de carbono volatilizado pela razão entre a massa molar de $\mathrm{CO}_{2}$ (44) e a massa molar de $\mathrm{C}$ (12).

\subsection{Emissões de resíduos industriais}

As emissões do uso de resíduos industriais no cultivo de cana foram calculadas por meio do uso de dois fatores: concentração de nitrogênio nas matérias orgânicas, definidas por Macedo (2008) como 0,36 kg N/m³ de vinhaça e $12,5 \mathrm{~kg} \mathrm{~N} / \mathrm{t}$ de torta de filtro; e, índice de emissão de nitrogênio por oxidação, cuja ordem de grandeza indicada pelo IPCC (2006) é de 1,22\%.

\subsection{Emissões da queima de canavial}

A palha queimada na pré-colheita se transforma, em termos estequiométricos, em emissões atmosféricas. Os fatores de emissão para a quantificação desses gases foi baseada nos índices apresentados na Tabela 51 e nas características de colheita descritas antes, na Tabela 45.

Tabela 51: Fatores de emissão para a queima de palha (GREET, 2010 apud SUGAWARA, 2012).

\begin{tabular}{llc}
\hline \multicolumn{1}{c}{ Emissões } & Unidade & Quantidade \\
\hline Volatile organic compounds (VOC) & $\mathrm{kg} / \mathrm{t}$ palha & 7.0 \\
\hline Carbon monoxide (biogenic) & $\mathrm{kg} / \mathrm{t}$ palha & 92.0 \\
\hline Nitrogen oxides & $\mathrm{kg} / \mathrm{t} \mathrm{palha}$ & 2.5 \\
\hline Particulates, $<10 \mathrm{um}$ & $\mathrm{kg} / \mathrm{t}$ palha & 7.8 \\
\hline Particulates, <2,5um & $\mathrm{kg} / \mathrm{t}$ palha & 3.9 \\
\hline Sulfur dioxide & $\mathrm{kg} / \mathrm{t}$ palha & 0.4 \\
\hline Dinitrogen monoxide & $\mathrm{kg} / \mathrm{t}$ palha & 0.07 \\
\hline Methane (biogenic) & $\mathrm{kg} / \mathrm{t} \mathrm{palha}$ & 2.7 \\
\hline Methane (biogenic) & $\mathrm{kg} / \mathrm{t}$ palha & 7.0 \\
\hline
\end{tabular}


As atividades que envolvem o revolvimento do solo acarretam na emissão do dióxido de carbono nele contido. A Tabela 52 discrimina as emissões estimadas de $\mathrm{CO}_{2}$ para a modificação de uso no solo, segundo os cálculos desenvolvidos na pesquisa de SUGAWARA (2012).

Tabela 52: Emissões estimadas de $\mathrm{CO} 2$ decorrentes do uso do solo pela cana-de-açúcar (SUGAWARA, 2012).

\begin{tabular}{lc}
\hline \multicolumn{1}{c}{ Parâmetros } & Quantidades \\
\hline $\mathrm{CO}_{2}^{\mathrm{i}}\left(\mathrm{kg} / \mathrm{ha}_{\text {desmatado }}\right)$ & 4.791 \\
$\Sigma \Delta$ Área (mil hadesmatado) & 4.116 \\
\hline Produção em 2010/11 (milhões $\mathrm{t})$ & 407 \\
\hline $\mathrm{CO}_{2}{ }^{\dagger}\left(\mathrm{kg} / \mathrm{kg}_{\text {cana }}\right)$ & 0,55 \\
\hline
\end{tabular}

\subsubsection{Emissões para o solo}

Os insumos aplicados no solo para a correção de suas características físico-químicas são constituídos parcialmente por metais pesados, os quais contribuem para emissões de poluentes neste meio.

Desta forma, o uso de produtos como corretivos agrícolas, fertilizantes minerais e pesticidas contabiliza parte dos aspectos ambientais relativos ao cultivo de cana-deaçúcar.

Visto que por critério de qualidade os derivados da cana apresentam teores desprezíveis de metais, e que o resíduo de seu processamento é reaproveitado no canavial, todos os metais que entram no sistema de cultivo tem como destino a sua emissão no solo.

A quantidade de metal existente em cada insumo agrícola aplicado na lavoura está detalhada na Tabela 53, enquanto que a Tabela 54 apresenta as emissões estimadas para a cana-de-açúcar. 
Tabela 53: Origem e teor de metais de pesados de produtos agrícolas utilizadas na cana-deaçúcar (SUGAWARA, 2012).

\begin{tabular}{lcccccccc}
\hline \multicolumn{1}{c}{ Dado } & Amônia & Ureia & $\begin{array}{c}\text { Nitrato de } \\
\text { amônio }\end{array}$ & MAP & SSP & KCl & Calcário & Gesso \\
\hline Prod. Nacional (\%) & 78 & 34 & 32 & 52 & 95 & 13 & 100 & 100 \\
\hline Importação (\%) & 22 & 66 & 68 & 48 & 5 & 87 & 0 & 0 \\
\hline $\begin{array}{l}\text { Teor de Cd de produto } \\
\text { nacional (mg/kg) }\end{array}$ & 0 & 0 & 0 & 2,5 & 3,0 & 0 & 0 & 0,8 \\
\hline $\begin{array}{l}\text { Teor de Cd de produto } \\
\text { importado (mg/kg) }\end{array}$ & 0,17 & 0,05 & 0,05 & 24,6 & 10,0 & 0,06 & - & - \\
\hline $\begin{array}{l}\text { Teor de Pb de produto } \\
\text { nacional (mg/kg) }\end{array}$ & 0 & 0 & 0 & 9 & 8,6 & 0 & 0 & 9,9 \\
\hline $\begin{array}{l}\text { Teor de } \mathrm{Pb} \text { de produto } \\
\text { importado }(\mathrm{mg} / \mathrm{kg})\end{array}$ & 4,40 & 1,10 & 1,9 & 23,7 & 110 & 5,5 & - & - \\
\hline $\begin{array}{l}\text { Teor de Ni de produto } \\
\text { nacional }(\mathrm{mg} / \mathrm{kg})\end{array}$ & 0 & 0 & 0 & 4 & 47 & 0 & 0 & 4,9 \\
\hline $\begin{array}{l}\text { Teor de Ni de produto } \\
\text { importado }(\mathrm{mg} / \mathrm{kg})\end{array}$ & 14,1 & 2,0 & 13,0 & 48,2 & 20,0 & 2,1 & - & - \\
\hline $\begin{array}{l}\text { Teor de Cu de produto } \\
\text { nacional }(\mathrm{mg} / \mathrm{kg})\end{array}$ & 0 & 0 & 0 & 12 & 27 & 0 & 6 & 10 \\
\hline
\end{tabular}

Tabela 54: Emissões de metais pesados para o solo pela cultura da cana-de-açúcar (SUGAWARA, 2012).

\begin{tabular}{|c|c|c|}
\hline Tipo de Metal & Unidade & Quantidade \\
\hline $\mathrm{Cd}$ & $\mathrm{mg} / \mathrm{kg}$ de cana & 0,010348 \\
\hline $\mathrm{Pb}$ & $\mathrm{mg} / \mathrm{kg}$ de cana & 0,222091 \\
\hline $\mathrm{Ni}$ & $\mathrm{mg} / \mathrm{kg}$ de cana & 0,120512 \\
\hline $\mathrm{Cu}$ & $\mathrm{mg} / \mathrm{kg}$ de cana & 0,130775 \\
\hline $\mathrm{Zn}$ & $\mathrm{mg} / \mathrm{kg}$ de cana & 0,545540 \\
\hline $\mathrm{Cr}$ & $\mathrm{mg} / \mathrm{kg}$ de cana & 0,158522 \\
\hline
\end{tabular}

\subsubsection{Emissões para a água}

A aplicação de fertilizantes e corretivos agrícolas é realizada de tal forma e condição, no território brasileiro, que fósforo, nitrogênio e potássio não são carreados superficialmente. Nesse sentido, não foram considerados no estudo a contaminação de águas superficiais (SUGAWARA, 2012).

Entretanto, Trivelin e Franco (2011) apontam que 5\% do total de nitrogênio oriundo de ureia e da amônia são convertidos em nitrato, sendo posteriormente lixiviado do solo e acumulado na água subterrânea. 


\subsubsection{2 $\underline{\text { Transportes }}$}

Os insumos quantificados no processo de cultivo da cana são transportados até o canavial de diferentes estados do país, como Riberia Grande (SP), Cubatão (SP) e Araripina (PE). Em casos específicos, o material é parcialmente importado, conforme descritivo dos países exportadores de fertilizantes, descriminado no sistema AliceWeb ${ }^{14}$ do Ministério do Desenvolvimento, Indústria e Comércio Exterior (MDIC) (SUGAWARA, 2012).

As distâncias entre os portos dos países exportadores até Santos foram calculadas mediante o uso do site Sea-Rates ${ }^{15}$, tal como realizado para outros subsistemas contemplados neste estudo. Uma vez que não foi possível determinar a distância entre o local das fábricas de produtos importados até os portos de seus respectivos países, foi adotada para fins de modelagem, uma distância padrão de $50 \mathrm{~km}$.

Já o percurso realizado entre o porto de Santos e as áreas agrícolas foi estimado a partir do site Google Maps ${ }^{16}$.

A Tabela 55 apresenta as distâncias de transporte dos insumos agrícolas, segundo as condições supramencionadas.

Quanto ao transporte dos resíduos da usina sucroalcooleira, Sugawara (2012) detalha que: $6 \%$ do material são transportados por caminhões ao longo de $7 \mathrm{~km} ; 31 \%$ são transportados por caminhões a distâncias de até $12 \mathrm{~km}$; e, 63\% são encaminhados a céu aberto.

Para todos os cenários, o recurso é aplicado no solo por sistema de aspersão, consumindo $0,69 \mathrm{kWh}$ de energia elétrica para o bombeamento.

\footnotetext{
14 www.aliceweb.desenvolvimento.gov.br

${ }^{15}$ www.searates.com/reference/portdistance

$16 \mathrm{https}: / / m a p s . g o o g l e . c o m . b r$
} 
Tabela 55: Distâncias de transporte dos insumos agrícolas da cana-de-açúcar (SUGAWARA, 2012).

\begin{tabular}{|c|c|c|c|c|c|c|c|c|c|c|}
\hline Origem- Destino & Amônia & Ureia & $\begin{array}{l}\text { Nitrato de } \\
\text { amônio }\end{array}$ & MAP & SSP & $\mathrm{KCl}$ & Calcário & Gesso & Mudas & $\begin{array}{l}\text { Resíduos } \\
\text { Industriais }\end{array}$ \\
\hline $\begin{array}{l}\text { Produção no país exportador-porto de } \\
\text { exportação }(\mathrm{km})\end{array}$ & 50 & 50 & 50 & 50 & 50 & 50 & - & - & - & - \\
\hline Porto exportador-porto de Santos (km) & 6.628 & 11.679 & 11.857 & 10.407 & 12.287 & 7.456 & - & - & - & - \\
\hline $\begin{array}{l}\text { Porto de Santos-municípios produtores de } \\
\text { cana }(\mathrm{km})\end{array}$ & 479 & 479 & 479 & 479 & 479 & 479 & - & - & - & - \\
\hline $\begin{array}{l}\text { Cubatão-municípios produtores de cana } \\
(\mathrm{km})\end{array}$ & 469 & 469 & 469 & 469 & 469 & 469 & - & - & - & - \\
\hline $\begin{array}{l}\text { Ribeira Grande-municípios produtores de } \\
\text { cana }(\mathrm{km})\end{array}$ & - & - & - & - & - & - & 425 & - & - & - \\
\hline $\begin{array}{l}\text { Araripina-municípios produtores de cana } \\
(\mathrm{km})\end{array}$ & - & - & - & - & - & - & - & 2.445 & - & - \\
\hline Local de produção-canavial & - & - & - & - & - & - & - & - & 30 & 32,3 \\
\hline $\begin{array}{l}\text { Produção no país exportador-porto de } \\
\text { exportação }(\mathrm{km})\end{array}$ & 50 & 50 & 50 & 50 & 50 & 50 & - & - & - & - \\
\hline Porto exportador-porto de Santos (km) & 6.628 & 11.679 & 11.857 & 10.407 & 12.287 & 7.456 & - & - & - & - \\
\hline
\end{tabular}


Os consumos decorrentes do bombeamento e aspersão de $1 \mathrm{~m}^{3}$ de vinhaça está descrito na Tabela 56.

Tabela 56: Dados da operação de $1 \mathrm{~m}^{3}$ pelo sistema de aspersão da vinhaça (SUGAWARA, 2012).

\begin{tabular}{lcc}
\hline Entrada/saída & Unidade & Quantidade \\
\hline Consumo energia & $\mathrm{MJ}$ & $8,6^{*} 10^{0}$ \\
\hline Consumo de diesel por trator & $\mathrm{kg}$ & $3,2^{*} 10^{-2}$ \\
\hline Emissão de $\mathrm{CO}_{2}$, fossil & $\mathrm{kg}$ & $1,0^{*} 10^{-1}$ \\
\hline Emissão de $\mathrm{N}_{2} \mathrm{O}$ & $\mathrm{kg}$ & $2,6^{*} 10^{-6}$ \\
\hline Emissão de $\mathrm{CH}_{4}$, fóssil & $\mathrm{kg}$ & $5,8^{*} 10^{-6}$ \\
\hline Emissão de $\mathrm{SO}_{2}$ & $\mathrm{~kg}$ & $1,7^{*} 10^{-4}$ \\
\hline Emissão de particulados & $\mathrm{kg}$ & $5,6^{*} 10^{-5}$ \\
\hline Emissão de NOx & $\mathrm{kg}$ & $1,2^{*} 10^{-3}$ \\
\hline Emissão de CO, fóssil & $\mathrm{kg}$ & $4,4^{*} 10^{-7}$ \\
\hline Emissão de hidrocarbonetos & $\mathrm{kg}$ & $1,2^{*} 10^{-4}$ \\
\hline
\end{tabular}

\subsubsection{Bancos de dados}

A construção do subsistema de cultivo de cana contou com adoção de bancos de dados contidos na base do Ecoinvent, selecionados de modo a representar o inventário de insumos auxiliares ao processo. A Tabela 57 lista os elementos e os respectivos bancos de dados utilizados.

Tabela 57: Bancos de dados do Ecoinvent adotados na produção de cana-de-açúcar (SUGAWARA, 2012).

\begin{tabular}{ll}
\hline \multicolumn{1}{c}{ Nome } & \multicolumn{1}{c}{ Elemento do Ecoinvent } \\
\hline Calcário & Limestone, milled, loose, at plant/CHU \\
\hline Gesso & Gypsum, mineral, at mine/CH $U$ \\
\hline Amônia & Ammonia, liquid, at regional storehouse/RER $U$ \\
\hline Ureia & Urea, as $N$, at regional storehouse/RER $U$ \\
\hline Nitrato de amônio & Ammonium nitrate, as $N$, at regional storehouse/RER $U$ \\
\hline MAP & Monoammonium phosphate, as $P 2 O 5$, at regional \\
SSP & storehouse/RER $U$ \\
\hline KCl & Single superphosphate, as P2O5, at regional storehouse/RERU \\
\hline Glifosato & Potassium chloride, as K2O, at regional storehouse/RER U \\
\hline Diuron & Glyphosate, at regional storehouse/RER $U$ \\
\hline Carbofuran & Diuron, at regional storehouse/RER $U$ \\
\hline Fipronil & Carbofuran, at regional storehouse/RER $U$ \\
\hline Tebuthiuron & Insecticides, at regional storehouse/RER $U$ \\
\hline Hexazinona & Herbicides, at regional storehouse/RER $U$ \\
\hline
\end{tabular}




\begin{tabular}{ll}
\hline \multicolumn{1}{c}{ Nome } & \multicolumn{1}{c}{ Elemento do Ecoinvent } \\
\hline Imazapique & Herbicides, at regional storehouse/RER U \\
\hline Ethyl Trinexapaque & Growth regulators, at regional storehouse/RER U \\
\hline Aplicação da vinhaça & Slurry spreading \\
\hline Transporte rodoviário & Lorry 7,5-16t, EURO 3/RER U Lorry 16-32t, EURO 3/RER U e \\
Transporte oceânico & Lorry 16-32t, EURO 3/RER $U$ \\
\hline
\end{tabular}

\subsubsection{Inventário do Ciclo de Vida do cultivo de cana}

A Tabela 58 sintetiza as cargas ambientais associadas a produção de 1t. de cana-deaçúcar.

Tabela 58: Inventário da produção de 1 kg de cana (SUGAWARA, 2012).

\begin{tabular}{lcc}
\hline Entradas/saídas & Unidade & Quantidade \\
\hline Entradas & $\mathrm{kg}$ & 0,653 \\
Carbon dioxide, in air & $\mathrm{m}^{2}$ & 0,0106 \\
Transformation, from pasture and meadow & $\mathrm{m}^{2}$ & 0,1175 \\
Transformation, from arable, non-irrigated & $\mathrm{m}^{2}$ & 0,1281 \\
Transformation, to arable, non-irrigated & $\mathrm{m}^{2} . \mathrm{a}$ & 0,1100 \\
Occupation, arable, non-irrigated & $\mathrm{kg}$ & 0,000094 \\
Ammonia, liquid, at regional storehouse/RER U & $\mathrm{kg}$ & 0,000700 \\
Urea, as N, at regional storehouse/RER U & $\mathrm{kg}$ & 0,000123 \\
Ammonium nitrate, as N, at regional storehouse/RER U & $\mathrm{kg}$ & 0,000006 \\
Monoammonium phosphate, as P2O5, at regional & $\mathrm{kg}$ & 0,000035 \\
storehouse/kg/RER & $\mathrm{kg}$ & 0,000387 \\
Monoammonium phosphate, as N, at regional & $\mathrm{kg}$ & 0,000774 \\
storehouse/kg/RER & $\mathrm{kg}$ & 0,005156 \\
Single superphosphate, as P2O5, at regional & $\mathrm{kg}$ & 0,002578 \\
storehouse/RER U & $\mathrm{kg}$ & 0,000811 \\
Potassium chloride, as K2O, /RER U & $\mathrm{kg}$ & 0,007950 \\
Limestone, milled, loose, at plant/CH U & $\mathrm{kg}$ & 0,002279 \\
Gypsum, mineral, at mine/CH U & $\mathrm{kg}$ & 0,000003 \\
Vinasse, at etanol production & $\mathrm{kg}$ & 0,000001 \\
Filter cake, at etanol production & $\mathrm{kg}$ & 0,000005 \\
Diesel, at regional storage & $\mathrm{kg}$ & 0,000003 \\
Glyphosate, at regional storehouse/RER U & $\mathrm{kg}$ & 0,0000005 \\
Diuron, at regional storehouse/RER U & & \\
Carbofuran, at regional storehouse/RER U & \\
Herbicides, at regional storehouse/RER U & & \\
Insecticides, at regional storehouse/RER U & & \\
\hline
\end{tabular}




\begin{tabular}{|c|c|c|}
\hline Entradas/saídas & Unidade & Quantidade \\
\hline Growth regulators, at regional storehouse & $\mathrm{kg}$ & 0,000001 \\
\hline Slurry spreading, by vacuum tanker/CH U & $m^{3}$ & 0,000049 \\
\hline Electricity - medium voltage, at grid - BR & $\mathrm{kWh}$ & 0,000523 \\
\hline Diesel, burned in building machine/GLO U & MJ & 0,006538 \\
\hline Transport, transoceanic freight ship/OCE U & t.km & 0,026749 \\
\hline Transport, lorry 7,5-16t, EURO3/RER U & t.km & 0,003356 \\
\hline Transport, lorry 16-32t, EURO3/RER U & t.km & 0,011842 \\
\hline \multicolumn{3}{|l|}{ Emissões para o Ar } \\
\hline Carbon dioxide, land transformation & $\mathrm{kg}$ & 0,059403 \\
\hline Volatile organic compounds (VOC) & $\mathrm{kg}$ & 0,000442 \\
\hline Carbon monoxide, biogenic & $\mathrm{kg}$ & 0,005814 \\
\hline Nitrogen oxides & $\mathrm{kg}$ & 0,095961 \\
\hline Particulates, $<10 u m$ & $\mathrm{~kg}$ & 0,000493 \\
\hline Particulates, $<2,5$ um & $\mathrm{kg}$ & 0,012128 \\
\hline Sulfur oxides & $\mathrm{kg}$ & 0,000025 \\
\hline Dinitrogen monoxide & $\mathrm{kg}$ & 0,000040 \\
\hline Methane (biogenic) & $\mathrm{kg}$ & 0,000171 \\
\hline Ammonia & $\mathrm{kg}$ & 0,000133 \\
\hline Ammonium, ion & $\mathrm{kg}$ & 0,000159 \\
\hline Carbon dioxide, fossil & $\mathrm{kg}$ & 0,009570 \\
\hline Methane, fossil & $\mathrm{kg}$ & 0,0000003 \\
\hline Sulfur dioxide & $\mathrm{kg}$ & 0,000002 \\
\hline Benzene & $\mathrm{kg}$ & 0,000016 \\
\hline Cadmium & $\mathrm{kg}$ & $2,3^{*} 10^{-8}$ \\
\hline Chromium & $\mathrm{kg}$ & $1,1^{*} 10^{-7}$ \\
\hline Copper & $\mathrm{kg}$ & $3,8^{*} 10^{-6}$ \\
\hline Nickel & $\mathrm{kg}$ & $1,6^{*} 10^{-7}$ \\
\hline Selenium & $\mathrm{kg}$ & $2,3^{*} 10^{-8}$ \\
\hline Zinc & $\mathrm{kg}$ & $2,2^{*} 10^{-6}$ \\
\hline Benzo(a)pyrene & $\mathrm{kg}$ & $6,8^{*} 10^{-8}$ \\
\hline Hydrocarbons, aromatic & $\mathrm{kg}$ & 0,000007 \\
\hline Carbon monoxide, fossil & $\mathrm{kg}$ & 0,000012 \\
\hline NMVOC, non-methane volatile organic compounds & $\mathrm{kg}$ & 0,006762 \\
\hline Hydrocarbons, unspecified & $\mathrm{kg}$ & $8,9^{*} 10^{-8}$ \\
\hline Particulates, unspecified & $\mathrm{kg}$ & $4,3^{*} 10^{-8}$ \\
\hline \multicolumn{3}{|l|}{ Emissões para a Água } \\
\hline Nitrate & $\mathrm{kg}$ & 0,000155 \\
\hline \multicolumn{3}{|l|}{ Resíduos Sólidos para tratamento } \\
\hline Carbofuran & $\mathrm{kg}$ & 0,0000054 \\
\hline
\end{tabular}




\begin{tabular}{lcc}
\hline Entradas/saídas & Unidade & Quantidade \\
\hline Diuron & $\mathrm{kg}$ & 0,0000012 \\
Fipronil & $\mathrm{kg}$ & 0,0000005 \\
Glyphosate & $\mathrm{kg}$ & 0,0000029 \\
Hexazinone & $\mathrm{kg}$ & 0,0000004 \\
Imazapic & $\mathrm{kg}$ & 0,0000016 \\
Tebuthiuron & $\mathrm{kg}$ & 0,0000013 \\
Trinexapac-ethyl & $\mathrm{kg}$ & 0,0000011 \\
Cadmium & $\mathrm{mg}$ & 0,0103480 \\
Lead & $\mathrm{mg}$ & 0,2220909 \\
Nickel & $\mathrm{mg}$ & 0,1205124 \\
Copper & $\mathrm{mg}$ & 0,1307754 \\
Zinc & $\mathrm{mg}$ & 0,5455398 \\
Chromium & $\mathrm{mg}$ & 0,1585222 \\
\hline
\end{tabular}

\subsubsection{Subsistema Produção de Etanol Hidratado}

O subsistema de produção de etanol hidratado contempla o transporte e o processamento da cana-de-açúcar até as usinas sucroalcooleiras. Assim, para o desenvolvimento do seu inventário, foram definidos os critérios de escopo abaixo.

a. Fonte de dados: secundários, obtidos por meio de modelagem.

b. Cobertura Temporal: período de 2008 a 2011. Todas as demais coberturas contempladas estão relacionadas aos bancos de dados utilizados.

c. Cobertura Geográfica: estado de São Paulo.

d. Cobertura Tecnológica: usinas sucroalcooleiras mistas, com tecnologia típica brasileira para a produção de açúcar e etanol hidratado.

\subsubsection{Cobertura Tecnológica}

O inventário do subsistema de produção de etanol hidratado foi construído em parceria com o Laboratório Nacional de Ciência e Tecnologia do Bioetanol (CTBE). 
A modelagem do processo foi executada mediante o uso do software Aspen Plus, a partir de informações como: as características tecnológicas do processo; correntes de entrada e saída do sistema; consumos energéticos; e, perfil dos equipamentos necessários para a manufatura de etanol hidratado e açúcar de uma indústria sucroalcooleira mista típica brasileira.

A escolha de usinas mistas para o estudo é justificada pela adoção de dois critérios de análise. O primeiro está baseado no perfil das unidades de produção do estado de São Paulo, já que das 147 usinas produtoras de etanol, 115 são mistas, representando cerca de $80 \%$ das unidades em funcionamento. Ainda, segundo a CONAB (2008), das 278 mil toneladas de cana processadas em São Paulo no ano de 2008, 257 mil toneladas são moídas em usinas mistas, o que caracteriza mais de $90 \%$ do volume total.

Sobre a capacidade produtiva da usina, considerou-se que a planta teria envergadura de processamento de $500 t_{c a n a} / h$, ou 2.000.000 tcana ano-safra. Conforme ratifica a CGEE (2009), praticamente metade da massa de cana é moída em unidades com capacidade de até 2.000 .000 t., operando em 167 dias efetivos, fundamentalmente em razão da composição das usinas paulistas.

Sobre as características de produção, foram adotadas as seguintes premissas: processo de fermentação em batelada alimentada com reciclo de fermento; sistema com queima direta do bagaço de cana, operando em regime de cogeração; caldeiras com baixa eficiência na produção de vapor (22 bar); autossuficiência na geração de energia; e repartição igualitária do caldo para a produção de etanol e açúcar. Ressaltase que o inventário considera apenas a produção de etanol de primeira geração, a partir dos colmos da cana-de-açúcar.

As emissões atmosféricas da queima do bagaço na caldeira foram estimadas com o uso de fatores de emissão indicados por GREET (2010), cujos valores estão apresentados a seguir:

- CO: $0,55 \mathrm{~g} / \mathrm{kg}$ bagaço;

- NOx: 0,54 g/kg bagaço;

- $\mathrm{N}_{2} \mathrm{O}: 0,03 \mathrm{~g} / \mathrm{kg}$ bagaço;

- SOx: 0,029 g/kg bagaço;

- $\mathrm{CH}_{4}: 0,23 \mathrm{~g} / \mathrm{kg}$ bagaço;

- VOC: 0,04 g/kg bagaço; 
- Particulados $\mathrm{PM}<10 \mu \mathrm{m}: 0,62 \mathrm{~g} / \mathrm{kg}$ bagaço; e

- Particulados PM <2,5 $\mu \mathrm{m}: 0,31 \mathrm{~g} / \mathrm{kg}$ bagaço.

\subsubsection{Critério de Alocação}

Segundo dados fornecidos pela CTBE (2013), o processamento de 1 tonelada de cana-de-açúcar para usinas com o perfil anteriormente descrito antes, resulta na obtenção de 55,1 kg de etanol e 51,1 kg de açúcar. Como tais produtos apresentam funções diferenciadas e são enquadrados como commidities, foi adotado para fins de modelagem o critério econômico de alocação.

Visto que a cobertura temporal para a produção de cana contempla os anos de 2008 a 2011, o mesmo período foi considerado para avaliar o preço médio dos produtos e, desta informação, calcular os percentuais de distribuição dos aspectos relacionados ao subsistema de produção de etanol hidratado. Os percentuais de alocação levantados estão apresentados na Tabela 59.

Tabela 59: Percentuais de Alocação de Etanol Hidratado e Açúcar

\begin{tabular}{lcccc}
\hline Produto & $\begin{array}{c}\text { Quantidade } \\
\text { produzida [kg/t }\end{array}$ cana] & $\begin{array}{c}\text { Preço } \\
{[\mathbf{R} \$ / \mathbf{k g}]}\end{array}$ & $\begin{array}{c}\text { Valor total da } \\
\left.\text { produção [R } \$ / \mathbf{t}_{\text {cana }}\right]\end{array}$ & $\begin{array}{c}\text { Percentuais de } \\
\text { Alocação }\end{array}$ \\
\hline Etanol hidratado & 55,1 & $\mathrm{R} \$ 1,29$ & $\mathrm{R} \$ 70,83$ & $67,1 \%$ \\
\hline Açúcar & 51,12 & $\mathrm{R} \$ 0,68$ & $\mathrm{R} \$ 34,76$ & $32,9 \%$ \\
\hline TOTAL & 106,22 & & $\mathrm{R} \$ 105,59$ & $100 \%$ \\
\hline
\end{tabular}

\subsubsection{Transporte}

Os transportes contemplados neste subsistema englobam aqueles necessários para o encaminhamento de insumos à usina, bem como o transporte de etanol hidratado até a unidade de transformação de eteno. 


\subsection{Transporte de insumos até a usina de etanol}

A transformação de cana em açúcar e etanol consume insumos como ácido sulfúrico, cal, químicos inorgânicos (polímero floculante), lubrificantes e água. $\mathrm{O}$ ácido sulfúrico é empregado para controle do $\mathrm{pH}$ do processo de fermentação da cana, enquanto que leite de cal é utilizado para tratamento do caldo.

Os químicos inorgânicos são aplicados em diversas etapas do processo para a manutenção das características técnicas de produção e tratamento dos efluentes. Os lubrificantes são demandados no funcionamento dos equipamentos da fábrica, sendo constantemente consumidos no processo. Por fim, a água é incorporada no sistema, dentre outros usos, para a diluição do leite de levedura.

Uma vez que definidas as matérias-primas requeridas no processo, foi realizado um levantamento do volume de material ofertado no mercado brasileiro, no que tange a oferta nacional e internacional dos insumos.

Segundo dados fornecidos pela ABIQUIM (2011) e MDIC (2011), a importação dos produtos anteriormente mencionados foi diminuta perante a produção nacional, de tal modo que as distâncias foram analisadas apenas para as unidades de fabricação brasileiras com a maior capacidade produtiva, vide Tabela 60 .

Tabela 60: Localização das unidades fornecedoras de insumos da produção de etanol hidratado.

\begin{tabular}{|c|c|c|}
\hline Produto & Unidade Fabril & Endereço da Fábrica \\
\hline Ácido sulfúrico & Vale Fertilizantes & Cubatão/SP \\
\hline Cal & Votorantim Cimentos & Camaçari/BA \\
\hline Óleo Lubrificante & $\begin{array}{l}\text { Diversas empresas do } \\
\text { estado de São Paulo }\end{array}$ & Diadema/SP \\
\hline Químicos Inorgânicos (polímero floculante) & Nalco & Suzano/SP \\
\hline
\end{tabular}

A localização das usinas de etanol no estado de São Paulo foi averiguada com base nos endereços informados no site da SCA Etanol do Brasil ${ }^{17}$ (SCA, 2013). De posse das informações, foram calculadas as distâncias médias ponderadas entre os locais de produção de insumos e as unidades sucroalcooleiras. Os resultados desta análise estão descritos na Tabela 61.

\footnotetext{
17 http://www.scalcool.com.br/unidades-produtoras/
} 
Tabela 61: Distâncias de transporte dos insumos da produção de etanol hidratado

\begin{tabular}{lc}
\hline Produto & Distância percorrida [km] \\
\hline Ácido sulfúrico & 463 \\
\hline Cal & 371 \\
\hline Óleo Lubrificante & 415 \\
Químicos Inorgânicos (polímero floculante) & 445 \\
\hline
\end{tabular}

\subsection{Transporte etanol hidratado até a indústria de eteno}

Para fins de modelagem, foi considerado que a indústria de produção de eteno encontra-se localizada nos estados de São Paulo e Rio de Janeiro, portanto, próxima à unidade de poliestireno.

Nesse âmbito, foram identificados quais modais de transporte comporiam o sistema, a fim de levar etanol hidratado para estes estados.

A referência para levantamento dessas informações foi à unidade da Braskem, localizada em Triunfo, já que a mesma é a única unidade brasileira responsável por produzir eteno a partir de etanol. Assim, segundo dados da Braskem (2013), 40\% do etanol recebido são transportados via sistema ferroviário, enquanto que a hidrovia responde por $50 \%$ da logística de álcool e a rodovia, por $10 \%$.

Distâncias médias ponderadas entre as usinas de etanol e a indústria de eteno foram calculadas para cada modal de transporte, considerando que o sistema hidroviário não seria aplicável para o estado de São Paulo, sendo este substituído pelo transporte rodoviário.

Ainda para o caso da hidrovia, devido à indisponibilidade de dados, admitiu-se como aproximação o transporte oceânico em substituição ao fluvial. Em virtude desta definição, foi estabelecida a distância entre o Porto de Santos (SP) e o Porto de Rio Grande (RS). Vale destacar, ainda sobre esta limitação, que a distância contabilizada para o sistema rodoviário somou cinco percursos distintos, quais sejam: [1] entre o fornecedor de etanol e o Porto de Santos; [2] entre o Porto de Rio Grande e a unidade de eteno; [3] entre o fornecedor de etanol de São Paulo e as unidades de eteno; [4], entre a produção de etanol e a estação ferroviária; e, [5] entre a estação ferroviária e as unidades de produção eteno. Os resultados da análise estão apresentados na Tabela 62. 
Tabela 62: Distâncias de transporte do etanol hidratado até a indústria de eteno

\begin{tabular}{lc}
\hline Modal de Transporte & Distância percorrida [km] \\
\hline Ferrovia & 1459 \\
\hline Hidrovia & 1243 \\
\hline Rodovia & 2062 \\
\hline
\end{tabular}

\subsubsection{Banco de Dados}

Para a constituição do subsistema de etanol hidratado, foram utilizados os bancos de dados da base Ecoinvent expostos na Tabela 63.

Tabela 63: Banco de dados do Ecoinvent adotados na produção de etanol hidratado

\begin{tabular}{ll}
\hline Produto & \multicolumn{1}{c}{ Banco de Dados } \\
\hline Água & Tap water, at user/RER $U$ \\
\hline Cal & Lime, hydrated, packed, at plant/CHU \\
\hline Ácido sulfúrico & Sulphuric acid, liquid, at plant/RER U \\
\hline Óleo lubrificante & Lubricating oil, at plant/RER U \\
\hline Outros químicos & Chemicals inorganic, at plant/GLO U \\
\hline Transporte da cana e do etanol & Lorry 16-32t, EURO 4/RER U e Lorry >32t, EURO 4/RER U \\
\hline Transporte dos insumos & Lorry 16-32t, EURO 3/RER U \\
\hline Transporte fluvial de etanol hidratado & Transport, barge/RER U \\
\hline $\begin{array}{l}\text { Transporte ferroviário de etanol } \\
\text { hidratado }\end{array}$ & Transport, freight, rail/RER U \\
\hline
\end{tabular}

\subsubsection{Inventário do Ciclo de Vida da produção de Etanol Hidratado}

A Tabela 64 sintetiza o inventário da produção de etanol hidratado (95\%vv) a partir de 1 t. cana-de-açúcar.

Tabela 64: Inventário da produção de etanol hidratado a partir de 1 tonelada de cana-de-açúcar

\begin{tabular}{lcc}
\hline Entradas/saídas & Unidade & Quantidade \\
\hline Produtos & & \\
Hydrated ethanol - CTBE/GP2 & $\mathrm{kg}$ & 55,1 \\
Sugar - CTBE/GP2 & $\mathrm{kg}$ & 51,12 \\
Vinasse - CTBE/GP2 & $\mathrm{kg}$ & 581,7 \\
Filter cake mud - CTBE/GP2 & $\mathrm{kg}$ & 35,21 \\
Ashes - CTBE/GP2 & $\mathrm{kg}$ & 5,45
\end{tabular}




\begin{tabular}{lcc}
\hline Entradas/saídas & Unidade & Quantidade \\
\hline Recursos & & \\
Occupation, industrial area & $\mathrm{m}^{2}$ & 0,0051 \\
Transformation, from arable, non-irrigated & $\mathrm{m}^{2}$ & 0,0001 \\
Transformation, from industrial area, built up & $\mathrm{m}^{2}$ & 0,0001 \\
Entradas & & \\
Sugarcane, at farm - Sao Paulo - CTBE & $\mathrm{kg}$ & 1000 \\
Tap water, at user - BR & $\mathrm{kg}$ & 2000 \\
Lime, hydrated, packed, at plant/CH U & $\mathrm{kg}$ & 1,35 \\
Sulphuric acid, liquid, at plant - BR & $\mathrm{g}$ & 264,76 \\
Chemicals inorganic, at plant/GLO U & $\mathrm{kg}$ & 0,00769 \\
Lubricating oil, at plant - BR & $\mathrm{kg}$ & 0,013 \\
Emissões para o Ar & & \\
Ethanol & $\mathrm{kg}$ & 0,0838 \\
Carbon dioxide, biogenic & \\
Carbon dioxide, biogenic & \\
Carbon monoxide, biogenic & $\mathrm{kg}$ & 42,72 \\
Nitrogen oxides & $\mathrm{kg}$ & 159,9 \\
Dinitrogen monoxide & $\mathrm{kg}$ & 0,124 \\
Sulfur oxides & $\mathrm{kg}$ & 0,123 \\
Methane, biogenic & $\mathrm{kg}$ & 0,00681 \\
NMVOC, non-methane volatile organic compounds, & $\mathrm{kg}$ & 0,00661 \\
unspecified origin & $\mathrm{kg}$ & 0,05105 \\
Particulates, < 10 um & $\mathrm{kg}$ & 0,00861 \\
Particulates, <2.5 um & $\mathrm{kg}$ & 0,14 \\
\hline & $\mathrm{kg}$ & 0,0698 \\
\hline
\end{tabular}

\subsubsection{Subsistema de Produção de Eteno a partir de Etanol}

Para a produção de eteno renovável, fez-se uso de estudo acadêmico realizado a partir de modelo construído com a ferramenta Aspen Plus, apenas e exclusivamente para efeito de quantificação de correntes de matéria e energia que circulam através das fronteiras deste processo elementar.

Nesses termos, não foram objetos da presente análise, as viabilidade logísticas e econômicas do referido processamento, nem tampouco os desdobramentos mercadológicos de sua implementação.

\footnotetext{
${ }^{18}$ Emissão devido à fermentação alcoólica.

${ }^{19}$ Emissão devido à queima do bagaço.
} 
Os critérios de escopo adotados para este subsistema são:

a. Fonte de dados: secundários.

b. Cobertura Temporal: 2012, no que tange ao grid nacional de oferta de energia elétrica. Todas as demais coberturas contempladas estão relacionadas aos bancos de dados utilizados.

c. Cobertura Geográfica: estado de Rio Grande do Sul.

d. Cobertura Tecnológica: desidratação catalítica de etanol hidratado em eteno, a partir de reatores adiabáticos de leito fixo.

\subsubsection{Características da Modelagem da Planta de Eteno}

O processo de desidratação foi inventariado com base em valores extraídos do estudo de Cameron et. al. (2012), o qual considera características da US Patent 4.396.789. Nesse caso, porém, providenciaram-se adequações de conteúdo em comparação as informações contidas naquele documento a fim de atender aos critérios de qualidade e pureza de eteno produto para a sua utilização na indústria de polímeros.

Neste contexto, a planta de desidratação catalítica modelada é composta por cinco etapas de processamento: [1] desidratação de etanol por reatores catalíticos de leito fixo; [2] separação; [3] destilação; [4] adsorção; e [5] destilação criogênica. A Figura 24 aponta de maneira estruturada os passos para a produção de eteno, a contar do fornecimento de etanol.

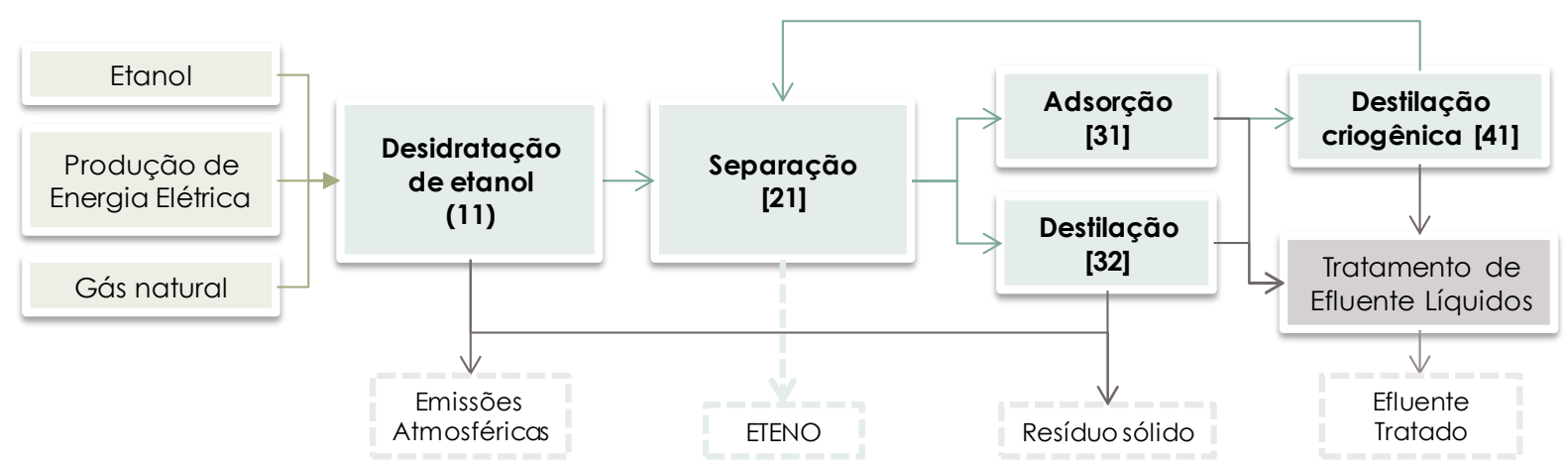

Figura 18: Produção de eteno a partir de etanol adotada para o desenvolvimento do ICV. 
O dimensionamento da planta visa converter 2,3 milhões de toneladas de etanol hidratado - com 5\% em massa de água - em um milhão de tonelada de eteno com pureza superior $99,96 \%$. O sistema trabalha em fluxo contínuo durante 365 dias ao ano, operando a uma temperatura de $400^{\circ} \mathrm{C}$ e pressão de 40 atm. Os balanços energéticos e mássicos apresentados no decorrer deste capítulo dizem respeito à uma hora de funcionamento do sistema, ou seja, ao processamento de $262.526 \mathrm{~kg}$ de etanol.

É válido ressaltar, contudo, que os aspectos ambientais pertinentes a este subsistema foram normalizados para desenvolvimento do perfil de impactos dos objetos em estudo, conforme as necessidades produtivas de uma tonelada de GPPS e HIPS evidenciadas nos inventários das Tabelas 42 e 43.

\subsection{Unidade de Desidratação de Etanol}

A seção de desidratação de etanol é composta por um trocador de calor, um equipamento de pressurização e três conjuntos de fornos e reatores catalíticos intercalados que operam em série.

O bombeamento e pressurização do etanol hidratado, em uma hora de operação, consomem $492 \mathrm{kWh}$ de energia elétrica, a qual é obtida via sistema de distribuição nacional. Após aumentar a pressão do composto de $1 \mathrm{~atm}$ para $41 \mathrm{~atm}$, a corrente de etanol passa pelo primeiro forno, onde $1702 \mathrm{~m}^{3}$ de gás natural são consumidos, a fim de elevar a temperatura do fluído de $25^{\circ} \mathrm{C}$ para $400^{\circ} \mathrm{C}$.

O etanol aquecido (ST111) é encaminhado, na forma de vapor, para o primeiro reator, que na presença de T-alumina converte o etanol hidratado em uma corrente (ST112) composta por: etanol; água; eteno; éter etílico; metano; acetaldeído; etano; ácido acético; e, hidrogênio. A concentração de eteno no primeiro reator é de 40,5\% e, devido à característica endotérmica da reação, a temperatura do fluxo de saída cai para $310^{\circ} \mathrm{C}$.

O segundo forno da unidade de desidratação tem por objetivo retomar a temperatura da corrente ST112 para $400^{\circ} \mathrm{C}$, o que resulta no consumo de $1498 \mathrm{~m}^{3}$ de gás natural. Após reagir no segundo reator, a corrente de saída (ST113), com mesma diversidade de componentes, passa a ter $52,7 \%$ de etanol em massa. 
No terceiro forno, a corrente ST113 é adicionada a outra corrente de Reciclo do processo, cuja composição contém 5,5\% em massa de etanol (derivada da unidade de destilação). Ambas as correntes são aquecidas a $400^{\circ} \mathrm{C}$, consumindo $1522 \mathrm{~m}^{3} \mathrm{de}$ gás natural. Ao entrar em contato com o catalisador de T-alumina, a corrente de saído do último reator (ST114) deixa o sistema com $51,5 \%$ em massa de etanol, seguindo para o trocador de calor localizado antes do primeiro forno, cujo objetivo é resfriar a corrente para uma temperatura de $82^{\circ} \mathrm{C}$.

$\mathrm{Na}$ Tabela 65 estão apresentadas as composições das correntes de entrada e saída de cada um dos reatores.

Tabela 65: Composição das correntes de entrada e saída dos reatores catalíticos da produção de eteno renovável

\begin{tabular}{|c|c|c|c|c|c|c|c|}
\hline \multirow[b]{2}{*}{ Componentes } & \multicolumn{2}{|c|}{ Reator 1} & \multicolumn{2}{|c|}{ Reator 2} & \multicolumn{3}{|c|}{ Reator 3} \\
\hline & $\begin{array}{c}\text { Entrada } \\
\text { ST111 } \\
{[\mathrm{kg}]}\end{array}$ & $\begin{array}{c}\text { Saída } \\
\text { ST112 } \\
\text { [kg] }\end{array}$ & $\begin{array}{c}\text { Entrada } \\
\text { ST112 } \\
{[\mathrm{kg}]}\end{array}$ & $\begin{array}{c}\text { Saída } \\
\text { ST113 } \\
\text { [kg] }\end{array}$ & $\begin{array}{c}\text { Entrada } \\
\text { ST113 } \\
{[\mathrm{kg}]}\end{array}$ & $\begin{array}{c}\text { Reciclo } \\
\text { [kg] }\end{array}$ & $\begin{array}{c}\text { Saída } \\
\text { ST114 } \\
{[\mathrm{kg}]}\end{array}$ \\
\hline Etanol & 249.399 & 73.261 & 73.261 & 19.872 & 19.872 & 4.545 & 24.417 \\
\hline Água & 13.126 & 81.634 & 81.635 & 102.376 & 102.376 & 1.434 & 103.810 \\
\hline Etileno & - & 106.310 & 106.310 & 138.431 & 138.431 & 389 & 138.821 \\
\hline Éter etílico & - & 1.003 & 1.003 & 1.445 & 1.445 & 200 & 1.646 \\
\hline Metano & - & 17 & 17 & 33 & 33 & 0,0 & 33 \\
\hline Acetaldeído & - & 191 & 191 & 240 & 240 & 532 & 772 \\
\hline Etano & - & 16 & 16 & 21 & 21 & 26 & 47 \\
\hline Ácido Acético & - & 81 & 81 & 96 & 96 & 0,0 & 96 \\
\hline Hidrogênio & - & 11 & 11 & 12 & 12 & 0,0 & 12 \\
\hline T-Alumina ${ }^{20}$ & - & 8 & 8 & 16 & 16 & - & 27 \\
\hline TOTAL & 262.525 & 262.533 & 262.533 & 262.542 & 262.542 & 7.126 & 269.678 \\
\hline
\end{tabular}

Ao final da unidade, a corrente ST114 é direcionada a um purgador para retirada de resquícios de T-alumina, que somam $27 \mathrm{~kg}$. Além do material em fase sólida, $535 \mathrm{~kg}$ de efluente líquido são encaminhados para a Estação de Tratamento. O produto final da unidade (ST115), desta forma, é composto por uma corrente de $269.116 \mathrm{~kg}$.

${ }^{20}$ Resíduo remanescente do catalisador. 


\subsection{Unidade de Separação}

A unidade de separação foi dimensionada, conforme Cameron et. al. (2012), para remover água e impurezas da corrente ST115, a fim de obter eteno a uma pureza de $99,96 \%$.

Para tanto, um trocador de calor é alocado no início do sistema de modo a reduzir a temperatura da corrente para $50^{\circ} \mathrm{C}$. Este trocador opera com água gelada a $32^{\circ} \mathrm{C}$, obtida por meio de chillers e torres de resfriamento.

Após passar por uma válvula de pressurização, a corrente ST115 resfriada segue para primeira torre flash, onde são geradas duas novas correntes. A primeira delas (ST211), retirada do fundo da torre, é encaminhada para a unidade de destilação. A segunda (ST222), obtida no topo da torre, adentra no segundo trocador de calor para atingir uma temperatura de aproximadamente $14^{\circ} \mathrm{C}$. Este trocador de calor faz uso de uma corrente de baixa temperatura $\left(-2^{\circ} \mathrm{C}\right)$ resultante da unidade de destilação criogênica.

$\mathrm{Na}$ segunda torre flash, a corrente ST222 resfriada é seccionada em outras duas. A corrente do fundo da torre (ST223) é somada a ST211, sendo direcionada para a unidade de destilação. Já o gás de topo (ST224), segue para a unidade de adsorção, com $98,6 \%$ de concentração em massa de etanol.

As composições das correntes da unidade de separação estão apresentadas na Tabela 66.

Tabela 66: Composição das correntes da unidade de separação - produção de eteno renovável

\begin{tabular}{lcccccc}
\hline Componentes & $\begin{array}{c}\text { Entrada } \\
\text { ST115 } \\
{[\mathbf{k g}]}\end{array}$ & $\begin{array}{c}\text { Saída de } \\
\text { fundo ST221 } \\
{[\mathbf{k g}]}\end{array}$ & $\begin{array}{c}\text { Saída de } \\
\text { topo ST222 } \\
{[\mathbf{k g}]}\end{array}$ & $\begin{array}{c}\text { Entrada } \\
\text { ST222 } \\
{[\mathbf{k g}]}\end{array}$ & $\begin{array}{c}\text { Saída de } \\
\text { fundo } \\
\text { ST223 } \\
{[\mathbf{k g}]}\end{array}$ & $\begin{array}{c}\text { Saída de } \\
\text { topo ST224 } \\
{[\mathbf{k g}]}\end{array}$ \\
\hline Etanol & 4.646 & 4379,0 & 267,1 & 267 & 155,7 & 111 \\
\hline Água & 111.269 & 110.813 & 430 & 430 & 399 & 31 \\
\hline Etileno & 150.417 & 379 & 150.066 & 150.066 & 9,2 & 150.057 \\
\hline Éter etílico & 1.789 & 186 & 1.604 & 1.604 & 14,1 & 1.589 \\
\hline Metano & 42 & 0,0 & 42 & 42 & 0,0 & 42 \\
\hline Acetaldeído & 791 & 501 & 290 & 290 & 30 & 260 \\
\hline Etano & 50 & 26 & 24 & 24 & 0,0 & 24 \\
\hline Ácido Acético & 100 & 100 & 0,2 & 0,2 & 0,2 & 0,0 \\
\hline Hidrogênio & 11,8 & 0,0 & 11,8 & 11,8 & 0,0 & 12 \\
\hline TOTAL & 269.116 & 116.383 & 152.734 & 152.734 & 608 & 152.126 \\
\hline
\end{tabular}




\subsection{Unidade de Destilação}

A destilação da planta de eteno tem por objetivo reduzir a concentração de água das correntes de fundo da unidade de separação (ST221 e ST223), a fim de obter um fluído com maior teor de etanol que será posteriormente reintroduzido na fase de desidratação como corrente de Reciclo. Para tanto, o sistema conta com uma torre de destilação, duas bombas, dois trocadores de calor e um compressor.

O primeiro trocador de calor trabalha com um fluxo de vapor d'água a uma temperatura de $147,6^{\circ} \mathrm{C}$, que visa vaporizar os componentes mais voláteis da corrente de fundo da torre, segregando-a em outras duas.

A primeira (ST311), em fase gasosa, retorna para o equipamento de destilação, permanecendo em circuito fechado no processo. A segunda (ST312), em fase líquida e com $99,9 \%$ em massa de água, é bombeada para o sistema de tratamento de efluente. $O$ consumo de energia da bomba é de 4,8 kWh.

O segundo trocador de calor, por sua vez, está localizado a posteriori da corrente de topo da torre (ST313). O equipamento opera com água gelada a $37,8^{\circ} \mathrm{C}$, cuja função é reduzir a temperatura de ST313. Ao deixar o trocador de calor, a fração de vapor da corrente cai de $100 \%$ para $54 \%$.

A fase vapor (ST314), com exatos $63,8 \%$ em massa de etanol, é encaminhada para o compressor que consome $861 \mathrm{kWh}$ e, então, direcionada como corrente de Reciclo para a unidade de desidratação. A fase líquida (ST315) retorna para a torre de destilação a partir de um sistema de bombeamento que consome $0,4 \mathrm{kWh}$.

Diante da configuração da unidade, apenas as correntes Reciclo e ST 312 deixam o processo. As composições dos fluxos de entrada e saída da destilação estão apresentadas na Tabela 67.

Tabela 67: Composição dos fluxos de entrada e saída da unidade de destilação - produção de eteno renovável

\begin{tabular}{lccc}
\hline Componentes & Entrada & \multicolumn{2}{c}{ Saída } \\
\cline { 2 - 4 } & $\begin{array}{c}\mathbf{S T 2 2 1 + S T 2 2 3} \\
{[\mathbf{k g}]}\end{array}$ & $\begin{array}{c}\mathbf{S T 3 1 2} \\
{[\mathbf{k g}]}\end{array}$ & $\begin{array}{c}\text { Reciclo } \\
{[\mathbf{k g}]}\end{array}$ \\
\hline Etanol & 4.534 & 0,5 & 4.545 \\
\hline Água & 111.211 & 109.764 & 1.434 \\
\hline Etileno & 388 & 0,0 & 389 \\
\hline Éter etílico & 200 & 0,0 & 200 \\
\hline Metano & 0,0 & 0,0 & 0,0 \\
\hline Acetaldeído & 530 & 0,0 & 532
\end{tabular}




\begin{tabular}{lccc}
\hline \multirow{2}{*}{ Componentes } & Entrada & \multicolumn{2}{c}{ Saída } \\
\cline { 2 - 4 } & $\begin{array}{c}\mathbf{S T 2 2 1 + S T 2 2 3} \\
{[\mathbf{k g}]}\end{array}$ & $\begin{array}{c}\mathbf{S T 3 1 2} \\
{[\mathbf{k g}]}\end{array}$ & $\begin{array}{c}\text { Reciclo } \\
{[\mathbf{k g}]}\end{array}$ \\
\hline Etano & 26 & 0,0 & 26 \\
\hline Ácido Acético & 100 & 100 & 0,0 \\
\hline Hidrogênio & 0,0 & 0,0 & 0,0 \\
\hline TOTAL & 116.990 & 109.864 & 7.126 \\
\hline
\end{tabular}

\subsection{Unidade de Adsorção}

O fluxo de vapor que deixa a unidade de destilação (ST224) é encaminhado à unidade de adsorção para a eliminação completa de água e etanol da corrente. Nessa etapa, o vapor é alimentado através de uma coluna de adsorção, na qual $6146 \mathrm{~kg}$ partículas de zeólita 13X são responsáveis por assegurar a absorção de água e etanol.

Dada à indisponibilidade de dados condizentes com o nível de aprofundamento deste estudo, não foram consideradas as cargas ambientais associadas à produção e ao transporte da corrente de Zeólita 13X. Ressalta-se, nesse caso, que a participação da mesma corrente foi avaliada em termos da incerteza que pode proporcionar, sendo esta contribuição considerada pouco significativa para os resultados obtidos pelo estudo.

O consumo de energia elétrica da coluna de adsorção é de $39 \mathrm{kWh}$ para atendimento das vazões mássicas expressas na Tabela 68. O efluente do processo é composto por $1846 \mathrm{~kg}$ de nitrogênio a $176,7^{\circ} \mathrm{C}$, aquecido por intermédio de um compressor que consume $87 \mathrm{kWh}$. As cargas referentes ao transporte do nitrogênio até a unidade de produção de eteno não foram consideradas em virtude de sua representatividade ser inferior ao limite de contribuição cumulativa mássica definida para o estudo.

Desta unidade, a corrente de topo da coluna (ST321), em fase vapor, é encaminhada para a unidade de destilação criogênica, enquanto que água e etanol compõem o efluente líquido do processo (ST322). 
Tabela 68: Composição das correntes de entrada e saída da unidade de adsorção - produção de eteno renovável

\begin{tabular}{|c|c|c|c|}
\hline \multirow[b]{2}{*}{ Componentes } & \multirow{2}{*}{$\begin{array}{c}\text { Entrada } \\
\text { ST224 } \\
{[\mathrm{kg}]}\end{array}$} & \multicolumn{2}{|c|}{ Saída } \\
\hline & & $\begin{array}{c}\text { ST321 } \\
{[\mathrm{kg}]}\end{array}$ & $\begin{array}{c}\text { ST322 } \\
\text { [kg] }\end{array}$ \\
\hline Etileno & 150.057 & 150.057 & 0,0 \\
\hline Etanol & 111 & 0,0 & 111 \\
\hline Água & 31 & 0,0 & 31 \\
\hline Éter etílico & 1.589 & 1.589 & 0,0 \\
\hline Metano & 42 & 42 & 0,0 \\
\hline Acetaldeído & 260 & 260 & 0,0 \\
\hline Hidrogênio & 12 & 12 & 0,0 \\
\hline Ácido Acético & 0,0 & 0,0 & 0,0 \\
\hline Etano & 24 & 24 & 0,0 \\
\hline$\overline{\text { TOTAL }}$ & 152.126 & 151.984 & 142 \\
\hline
\end{tabular}

Após três anos de funcionamento, a zeólita deve ser integralmente trocada para a manutenção da eficiência da coluna de adsorção.

\subsection{Unidade de Destilação Criogênica}

A unidade de destilação criogênica projetada por Cameron et.al. (2012) foi dimensionada para assegurar a concentração de 99,96\% de eteno na corrente de produto da planta, removendo etano e outras impurezas do processo de desidratação. Neste contexto, três trocadores de calor, uma bomba, uma válvula de despressurização e uma torre de destilação são requeridos pela unidade.

O primeiro trocador de calor é responsável por receber a corrente ST321 a fim de reduzir, bruscamente, a temperatura de $6,8^{\circ} \mathrm{C}$ para $-14^{\circ} \mathrm{C}$. Entretanto, para garantir o desempenho do sistema, outra redução de temperatura é promovida na ST321, por meio de uma válvula de despressurização, de modo que esta atinja $-37,3^{\circ} \mathrm{C}$.

Uma vez garantida as condições de temperatura, a corrente é encaminhada para a torre de destilação criogênica, e nesta é seccionada em duas frações (ST411 e ST412) que, em ambos os casos, são direcionadas para trocadores de calor.

A corrente ST411, obtida em estado líquido do fundo da coluna, é aquecida por meio de água a $37,8^{\circ} \mathrm{C}$ - derivada do trocador de calor da unidade de destilação -, resultando na formação de duas novas correntes. A primeira (ST413), em estado gasoso, retorna para a torre de destilação, permanecendo em circuito fechado. 
A segunda (ST414), em estado líquido e com concentração superior a 77\% de éter etílico, é encaminhada diretamente para o sistema de tratamento de efluentes.

Já a corrente de topo da coluna, denominada de ST412, é retirada do sistema com 99,96\% em massa de eteno, ou seja, dentro dos padrões pré-estabelecidos para a planta. Devido à característica de baixa temperatura $\left(-55^{\circ} \mathrm{C}\right)$, a ST412 é bombeada para o primeiro trocador de calor da unidade de destilação criogênica e deste, para o segundo trocador de calor da unidade de destilação.

O consumo de energia do sistema de bombeamento é de $11 \mathrm{kWh}$ para as vazões mássicas apresentadas na Tabela 69, na qual estão apresentadas as composições das correntes de entrada e saída da unidade.

Tabela 69: Composição das correntes de entrada e saída da unidade de destilação criogênica produção de eteno renovável

\begin{tabular}{lccc}
\hline Componentes & $\begin{array}{c}\text { Entrada } \\
\mathbf{S T 3 2 2} \\
{[\mathbf{k g}]}\end{array}$ & $\begin{array}{c}\text { ST414 } \\
{[\mathbf{k g ]}}\end{array}$ & $\begin{array}{c}\text { Saída } \\
\text { ST412 } \\
{[\mathbf{k g}]}\end{array}$ \\
\hline Etileno & 150.057 & 188 & 149.868 \\
\hline Etanol & 0,0 & 0,0 & 0,0 \\
\hline Água & 0,0 & 0,0 & 0,0 \\
\hline Éter etílico & 1.589 & 1.589 & 0,0 \\
\hline Metano & 42 & 0,0 & 42 \\
\hline Acetaldeído & 260 & 260 & 0,0 \\
\hline Hidrogênio & 12 & 0,0 & 12 \\
\hline Ácido Acético & 0,0 & 0,0 & 0,0 \\
\hline Etano & 24 & 11 & 13 \\
\hline TOTAL & 151.984 & 2.049 & 149.935 \\
\hline
\end{tabular}

\subsection{Emissões atmosféricas}

As emissões atmosféricas diretas do processo estão associadas, fundamentalmente, à combustão de gás natural nos fornos da unidade de desidratação de etanol. Em razão da indisponibilidade de dados, os balanços estequiométricos para quantificação dos poluentes consideraram a combustão completa do combustível.

A composição volumétrica do gás natural adotada para os cálculos segue aquela definida como padrão pela Comgás (COMGAS, 2013), qual seja: 89\% de metano; $6 \%$ de etano; $1,8 \%$ de propano; $1 \%$ de butano; $1,5 \%$ de dióxido de carbono; e, $0,7 \%$ de nitrogênio. 
Ainda, para averiguar a quantidade de mols de cada componente do gás natural, presumiu-se que este se encontra em condições normas de temperatura e pressão (294K e 1atm) e que tenha comportamento ideias para as condições em que a análise ocorreu. Assim, a Lei Geral dos gases, descrita seguir pela Equação 12, foi utilizada para o desenvolvimento dos cálculos.

$$
P V=n R T
$$

Onde:

$\mathrm{P}=$ pressão em atm;

$\mathrm{V}=$ volume em litros;

$\mathrm{n}=$ número de mols

$\mathrm{R}=$ constante universal dos gases perfeitos, equivalente a $0,082 \frac{\mathrm{atm} * L}{\mathrm{~mol} * K}$

$\mathrm{T}=$ temperatura em Kelvin.

Assim, a combustão de $4722 \mathrm{~m}^{3}$ de gás natural requer $30.925 \mathrm{~kg}$ de ar, resultando na emissão de: $38 \mathrm{~kg}$ de $\mathrm{N}_{2}$; $9643 \mathrm{~kg}$ de $\mathrm{CO}_{2}$; e, $7340 \mathrm{~kg}$ de $\mathrm{H}_{2} \mathrm{O}$.

Vale ressaltar que o conteúdo de etano presente na corrente ST414, equivalente a $11,3 \mathrm{~kg}$, foi classificado como emissão atmosférica, uma vez que este hidrocarboneto permanece em estado gasoso em condições normais de temperatura e pressão.

\subsection{Emissões para o solo}

As emissões para solo no subsistema de produção de eteno renovável ocorrem em dois momentos distintos. O primeiro deles é em decorrência do uso de T-alumina no processo de desidratação de etanol, no qual são liberados $26,8 \mathrm{~kg}$ de resíduos sólidos para a manufatura de $150 \mathrm{~kg}$ de eteno.

Além deste, o processo de adsorção faz uso de partículas de zeólitas 13X, que devem ser renovadas a cada três anos para manutenção de desempenho do equipamento. Assim, considerando que a planta opera 365 dias ao ano, 24hs/d, o volume de resíduo gerado para os mesmos $150 \mathrm{~kg}$ de produto é equivalente a $0,23 \mathrm{~kg}$. 


\subsection{Emissões para a água}

Conforme descrito anteriormente, a transformação de etanol em eteno acarreta na geração de compostos químicos não desejados, como: água, éter etílico e acetaldeído. Assim, durante o processo contemplado nesse subsistema, três efluentes líquidos são subtraídos da corrente de produto, nas seguintes unidades: desidratação de etanol, adsorção, e destilação criogênica. As composições dessas emissões para a produção de $150 \mathrm{~kg}$ de eteno estão apresentadas na Tabela 70.

Tabela 70: Composição química dos efluentes líquidos da produção de eteno renovável.

\begin{tabular}{lcccc}
\hline Componentes & $\begin{array}{c}\text { Desidratação de } \\
\text { etanol [kg] }\end{array}$ & $\begin{array}{c}\text { Destilação } \\
{[\mathbf{k g}]}\end{array}$ & $\begin{array}{c}\text { Adsorção } \\
{[\mathbf{k g}]}\end{array}$ & $\begin{array}{c}\text { Destilação } \\
\text { Criogênica [kg] }\end{array}$ \\
\hline Etanol & 9 & 0,45 & 111 & 0,0 \\
\hline Água & 221 & 109.764 & 31 & 0,0 \\
\hline Etileno & 299 & 0,0 & 0,0 & 188 \\
\hline Éter etílico & 3,6 & 0,0 & 0,0 & 1.589 \\
\hline Metano & 0,1 & 0,0 & 0,0 & 0,0 \\
\hline Acetaldeído & 1,6 & 0,0 & 0,0 & 260 \\
\hline Etano & 0,1 & 0,0 & 0,0 & 11 \\
\hline Ácido Acético & 0,2 & 99,8 & 0,0 & 0,0 \\
\hline Hidrogênio & 0,0 & 0,0 & 0,0 & 0,0 \\
\hline \multicolumn{1}{c}{ TOTAL } & 562 & 109.864 & 142 & 2.049 \\
\hline
\end{tabular}

Para fins de modelagem, admitiu-se que antes de ser lançado no ambiente, cada componente da corrente líquida seria tratado em uma Estação de Tratamento de Efluentes com eficiência de remoção de $95 \%$. Isto posto, a emissão de poluentes lançada efetivamente para a água corresponde a $5 \%$ dos valores apresentados na Tabela 70.

\subsection{Transporte}

As características do transporte de eteno renovável até a planta de poliestireno foi estimada, segundo os moldes daquela existente para o envio de eteno de origem 
fóssil. Ou seja, adotou-se o sistema via tubovias, com uma distância de 2,5km entre fábricas.

\subsection{Banco de Dados}

Para a construção do subsistema de produção de eteno renovável, foram utilizados os bancos de dados da base Ecoinvent expostos na Tabela 71.

Tabela 71: Banco de Dados adotado para a composição do subsistema de produção de eteno a partir de etanol.

\begin{tabular}{ll}
\hline Produto & \multicolumn{1}{c}{ Distância percorrida [km] } \\
\hline Água & Tap water, at user/RER $U$ \\
\hline Transporte de eteno via tubovia & Transport, by pipeline, onshore/RER U \\
\hline
\end{tabular}

\subsection{Inventário do Ciclo de Vida de Eteno a partir de Etanol}

A Tabela 72 traz o ICV da produção de eteno decorrente de fonte renovável, aqui representado pelo etanol de cana-de-açucar.

Tabela 72: Inventário da produção de 1 tonelada de eteno a partir de etanol

\begin{tabular}{lcc}
\hline Entradas/saídas & Unidade & Quantidade \\
\hline Produtos & ton & 1 \\
$\quad$ Eteno & & \\
Entradas & $\mathrm{kg}$ & 1750,9303 \\
C2H6O hydrated mix, 5\% water, at transportation/BR & $\mathrm{kg}$ & 12,3128 \\
$\quad$ Nitrogênio & $\mathrm{kg}$ & 0,1779 \\
T-alumina & $\mathrm{kg}$ & 0,0016 \\
Zeolite 13x & $\mathrm{kg}$ & 1270,6096 \\
R 501 - propylene & $\mathrm{kWh}$ & 4,5423 \\
Electricity - medium voltage, at grid 2012/ BR & $\mathrm{m}$ & 31,4922 \\
Heat, natural gas, at industrial furnace, for C2H4 & & \\
production >100kW/BR U & & \\
Emissões para o Ar & $\mathrm{kg}$ & 64,3168 \\
Carbon dioxide, fossil & $\mathrm{kg}$ & 0,0756 \\
Ethanol & $\mathrm{kg}$ & 0,2560 \\
$\quad$ Nitrogen & $\mathrm{kg}$ & 48,9547 \\
Water & & \\
Emissões para a Água & &
\end{tabular}




\begin{tabular}{|c|c|c|}
\hline Entradas/saídas & Unidade & Quantidade \\
\hline Acetaldehyde & $\mathrm{kg}$ & 0,0873 \\
\hline Acetic acid & $\mathrm{kg}$ & 0,0333 \\
\hline Diethyl-ether & $\mathrm{kg}$ & 0,5312 \\
\hline Ethane & $\mathrm{kg}$ & 0,0000 \\
\hline Ethanol & $\mathrm{kg}$ & 0,0404 \\
\hline Ethylene & $\mathrm{kg}$ & 0,1625 \\
\hline Hidrogen & $\mathrm{kg}$ & 0,0000 \\
\hline Methane & $\mathrm{kg}$ & 0,0000 \\
\hline Water & $\mathrm{kg}$ & 36,6879 \\
\hline \multicolumn{3}{|c|}{ Emissões para o Solo } \\
\hline Aluminium ${ }^{21}$ & $\mathrm{~kg}$ & 0,1794 \\
\hline
\end{tabular}

${ }^{21}$ A corrente de alumínio foi apontada no presente ICV para representar as perdas de Zeólita 13X e TAlumina ocorridas no processo. Admitiu-se, mais uma vez, neste caso não haver tratamento do rejeito previamente ao seu lançamento no solo. 


\section{RESULTADOS}

\subsection{PeRFIL DE IMPACTO AMBIENTAL DO GPPS DE ORIGEM FósSIL E PARCIALMENTE RENOVÁVEL}

Os Inventários de Ciclo de Vida elaborados tanto para o GPPS fóssil quanto para aquele de origem parcialmente renovável compreendem cerca de 1000 aspectos ambientais expressos na forma de fluxos elementares de entrada e saída, todos eles identificados e quantificados em função das premissas descritas no Capítulo 6 deste trabalho.

No que se refere ao consumo de recursos naturais para a produção de GPPS fóssil, destacam-se o uso de gás natural, óleo cru (petróleo) e água. De forma análoga, o GPPS produzido a partir de eteno renovável, também apresenta consumos significativos para os insumos citados anteriormente, com acréscimo da cana-deaçúcar.

Quanto ao gás natural em específico, este foi empregado como matéria-prima para obtenção de químicos básicos e na geração de energia térmica, para ambos os poliestirenos cristal.

O petróleo, de sua parte, aparece como recurso natural na obtenção de nafta e GLP utilizados também para a manufatura dos intermediários básicos.

O consumo de água nos sistemas de produto tem mais de $95 \%$ de seu volume aplicado indiretamente ao processo. Este ocorre em verdade na produção de energia elétrica, em que o modal hidrelétrico é contribuinte majoritário para a matriz nacional. Neste âmbito, observa-se que muito embora a água não sofra alteração de suas características originais quando da produção de energia, o fato desta constituir-se em fluxo de saída deste processo para o ambiente, a transforma em rejeito de processo. Os fluxos de saída, por outro lado, estão segregados em três grupos distintos, a saber: emissões atmosféricas; efluentes líquidos, e resíduos sólidos.

Quanto às emissões atmosféricas, o vapor de água resultante dos processos de resfriamento, bem como o lançamento de dióxido de carbono $\left(\mathrm{CO}_{2}\right)$, monóxido de carbono (CO), óxidos de enxofre $\left(\mathrm{SO}_{\mathrm{x}}\right)$, metano $\left(\mathrm{CH}_{4}\right)$, óxidos de nitrogênio $\left(\mathrm{NO}_{\mathrm{x}}\right)$ e materiais particulados, constituem os principais aspectos para ambos os poliestirenos. 
Vale ressaltar, porém, que a origem e a quantidade das emissões variam entre os produtos, visto às características do processo de cultivo de cana-de-açúcar e processamento de etanol.

Quanto às emissões para água, cada qual dos ICVs apresenta contribuições distintas. Perdas de óleo cru oriundas no transporte transoceânicos e efluentes gerados no subsistema de poliestireno são comuns para ambos os GPPS. Entretanto, a adoção de insumos agrícolas no cultivo de cana-de-açúcar aporta no lançamento de defensivos e nutrientes a corpos hídricos, agregando carga de poluentes adicional para o poliestireno cristal de fonte parcialmente renovável.

De forma completar, a geração de resíduos sólidos possuiu como aspecto de destaque a emissão de óleos provenientes da exploração de petróleo onshore internacional.

Assim, as produções de 1,0t GPPS fóssil e 1,0t de GPPS parcialmente renovável são constituídas por um conjunto específico de aspectos ambientais que resultam em impactos às condições originais do meio ambiente.

As magnitudes e significâncias desses impactos foram quantificadas com base no método ReCiPe Midpoint $(\mathrm{H}) \mathrm{V} 1.07$ para as treze categorias de impacto selecionadas para o estudo: Mudanças climáticas; Depleção da camada de ozônio; Toxicidade humana; Formação de Oxidantes Fotoquímicos; Formação de Material Particulado; Acidificação Terrestre; Eutrofização de Água Doce; Ecotoxicidade Terrestre; Ecotoxicidade Aquática; Ocupação de Solo Agricultável; Transformação de Áreas Naturais; Depleção de Água; e Depleção de Recurso Fóssil. Os resultados da Avaliação de Impactos Ambientais para cada um dos poliestirenos cristal estão apresentados na Tabela 73 .

Tabela 73: Perfil de Impacto Ambiental do GPPS fóssil e do GPPS parcialmente renovável

\begin{tabular}{lccc}
\hline Categorias de Impacto & Unidades & GPPS Fóssil & $\begin{array}{c}\text { GPPS parcialmente } \\
\text { renovável }\end{array}$ \\
\hline Mudanças Climáticas (MC) & $\mathrm{kg} \mathrm{CO}$ eq & $1,41 \mathrm{E}+03$ & $3,23 \mathrm{E}+03$ \\
Depleção da Camada de Ozônio (DO) & $\mathrm{kg} \mathrm{CFC-11} \mathrm{eq}$ & $5,63 \mathrm{E}-04$ & $5,24 \mathrm{E}-04$ \\
\hline Acidificação Terrestre (AT) & $\mathrm{kg} \mathrm{SO}$ eq & $4,09 \mathrm{E}+00$ & $9,75 \mathrm{E}+02$ \\
\hline Eutrofização de Água Doce (EU) & $\mathrm{kg} \mathrm{P}$ eq & $2,05 \mathrm{E}-02$ & $1,87 \mathrm{E}-02$ \\
\hline Toxicidade Humana (TH) & $\mathrm{kg} \mathrm{1,4-DB}$ eq & $7,73 \mathrm{E}+01$ & $8,72 \mathrm{E}+01$ \\
\hline Formação de Oxidantes Fotoquímicos (OF) & $\mathrm{kg} \mathrm{NMVOC}$ & $1,01 \mathrm{E}+01$ & $1,73 \mathrm{E}+03$ \\
Formação de Material Particulado (MP) & $\mathrm{kg} \mathrm{PM10} \mathrm{eq}$ & $1,21 \mathrm{E}+00$ & $6,11 \mathrm{E}+02$ \\
\hline Ecotoxicidade Terrestre (ET) & $\mathrm{kg} \mathrm{1,4-DB}$ eq & $9,38 \mathrm{E}-02$ & $5,78 \mathrm{E}+00$
\end{tabular}




\begin{tabular}{|c|c|c|c|}
\hline Categorias de Impacto & Unidades & GPPS Fóssil & $\begin{array}{c}\text { GPPS parcialmente } \\
\text { renovável }\end{array}$ \\
\hline Ecotoxicidade Aquática (EA) & $\mathrm{kg} 1,4-\mathrm{DB}$ eq & $1,56 \mathrm{E}+00$ & $3,31 \mathrm{E}+00$ \\
\hline Ocupação de Solo Agricultável (SA) & $m^{2}$ & $7,38 \mathrm{E}-02$ & $1,97 \mathrm{E}+03$ \\
\hline Transformação de Áreas Naturais (AN) & $\mathrm{m}^{2}$ & $1,21 \mathrm{E}-01$ & 1,13E-01 \\
\hline Depleção de Água (DA) & $m^{3}$ & $1,34 \mathrm{E}+01$ & $5,52 E+01$ \\
\hline Depleção de Recurso Fóssil (DF) & kg oil eq & $1,05 \mathrm{E}+03$ & $1,00 \mathrm{E}+03$ \\
\hline
\end{tabular}

A partir dos dados constantes da Tabela 73, foi possível elaborar o Gráfico 5 , no qual é realizada a comparação percentual entre desempenhos ambientais dos produtos em análise. Conforme evidenciado em ambos os dispositivos sinóticos, os perfis ambientais apresentam distinções expressivas, com variações de magnitude de impacto superiores a 100 para quatro, das treze categorias de impacto.

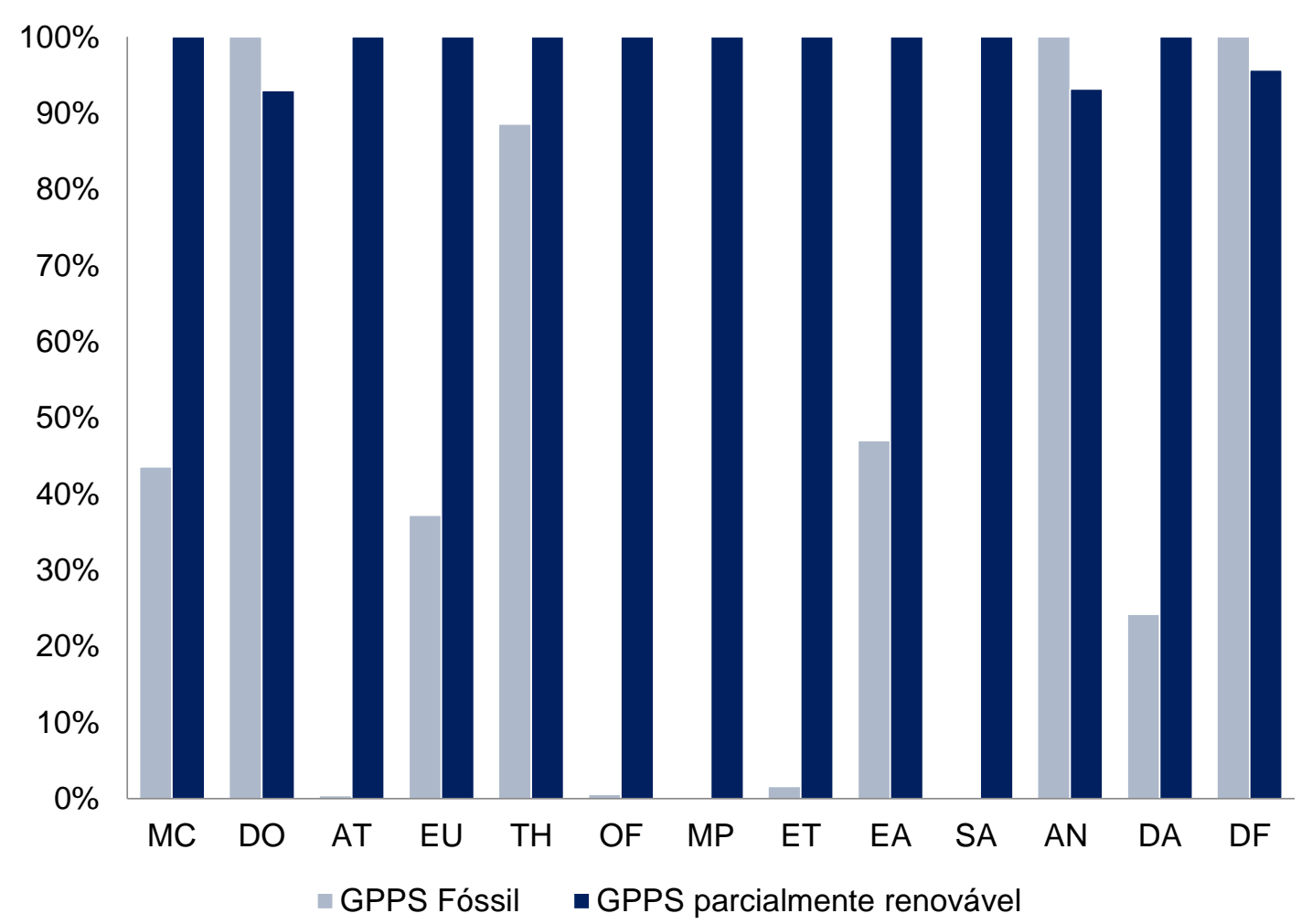

Gráfico 5: Comparação percentual dos desempenhos ambientais do GPPS fóssil e do GPPS parcialmente renovável. 


\subsubsection{Mudanças Climáticas}

A respeito das mudanças climáticas, a diferença entre o impacto ocasionado pelo subsistema do GPPS fóssil e o GPPS verde 22 foi de $56 \%$. Apesar dos aspectos ambientais mais relevantes serem similares para ambos os materiais, a sua origem e magnitude se distinguem em decorrência do uso de ativo renovável.

A Tabela 74 apresenta os tipos de emissões mais significativas para este impacto.

Tabela 74: Principais aspectos ambientais contribuintes para a categoria de Mudanças Climáticas na produção de GPPS

\begin{tabular}{lcccc}
\hline \multirow{2}{*}{ Aspecto Ambiental } & \multicolumn{2}{c}{ GPPS Fóssil } & \multicolumn{2}{c}{$\begin{array}{c}\text { GPS parcialmente } \\
\text { renovável }\end{array}$} \\
\cline { 2 - 5 } & $\begin{array}{c}\text { Quantidade } \\
{\left[\mathbf{k g ~ C O}_{\mathbf{2}} \text { eq }\right]}\end{array}$ & $\begin{array}{c}\text { Contribuição } \\
{[\%]}\end{array}$ & $\begin{array}{c}\text { Quantidade } \\
{\left[\mathbf{k g ~ C O}_{\mathbf{2}} \text { eq }\right]}\end{array}$ & $\begin{array}{c}\text { Contribuição } \\
{[\%]}\end{array}$ \\
\hline Dióxido de carbono, fóssil & $\mathbf{1 , 1 2 \mathrm { E } + \mathbf { 0 3 }}$ & $\mathbf{7 9 , 6 \%}$ & $\mathbf{1 , 4 0 \mathrm { E } + \mathbf { 0 3 }}$ & $\mathbf{4 3 , 2} \%$ \\
\hline Metano, fóssil & $1,93 \mathrm{E}+02$ & $13,7 \%$ & $1,58 \mathrm{E}+02$ & $4,9 \%$ \\
\hline $\begin{array}{l}\text { Dióxido de carbono, mudança de uso } \\
\text { do solo }\end{array}$ & $5,48 \mathrm{E}+01$ & $3,9 \%$ & $1,11 \mathrm{E}+03$ & $34,4 \%$ \\
\hline Metano, biogênico & $2,33 \mathrm{E}+01$ & $1,7 \%$ & $1,08 \mathrm{E}+02$ & $3,4 \%$ \\
\hline Monóxido de dinitrogênio & $2,63 \mathrm{E}+00$ & $0,2 \%$ & $2,70 \mathrm{E}+02$ & $8,4 \%$ \\
\hline Outros & $1,34 \mathrm{E}+01$ & $1,0 \%$ & $1,84 \mathrm{E}+02$ & $5,7 \%$ \\
\hline Total & $\mathbf{1 , 4 1 E + 0 3}$ & $\mathbf{1 0 0 , 0 \%}$ & $\mathbf{3 , 2 3 E}+\mathbf{0 3}$ & $\mathbf{1 0 0 , 0} \%$ \\
\hline
\end{tabular}

De acordo com a análise dos resultados, os processos de extração, purificação e transporte e consumo do gás natural, em que as características tecnológicas e de operação resultam em eventuais vazamentos do gás em suas condições naturais, foram as principais atividades que contribuíram para a emissão de gases efeito estufa no GPPS Fóssil, contemplando 79,5\% da carga ambiental.

Ressalta-se que esses processos contribuem de forma expressiva, também, para a emissão de dióxido de carbono, uma vez que parte do gás extraído é utilizada como fonte de energia nas atividades de extração e purificação de petróleo e de gás, bem como para a geração de vapor, de tal modo que para o GPPS fóssil, 63,1\% das emissões de $\mathrm{CO}_{2 e q}$ são derivadas desses processos.

\footnotetext{
${ }^{22}$ Assim denominado por possuir eteno de origem renovável em sua composição. Nomenclatura válida também para o poliestireno de alto impacto (HIPS).
} 
De forma menos significativa, esses mesmos processos representam em conjunto aproximadamente $34,2 \%$ das emissões de $\mathrm{CO}_{2 e q}$ no subsistema de produção do GPPS verde. Isto porque, o gás natural consumido no processo de manufatura de eteno fóssil é substituído por aquele derivado da desidratação de etanol.

É em decorrência desta mesma troca de insumos que o cultivo de cana de açúcar aporta em $47 \%$ do impacto nas mudanças climáticas, justificando a origem das emissões de dióxido de carbono por mudança de uso do solo e de monóxido de dinitrogênio, resultante do uso de fertilizantes agrícolas e processos naturais de nitrificação desses compostos. Destaca-se, nesse âmbito, que para cada quilo de cana produzida são gerados $0,06 \mathrm{~kg}$ de $\mathrm{CO}_{2}$ pela transformação do solo.

Com respeito às emissões de metano, estas foram identificadas na geração da energia hidroelétrica utilizada por todos os processos elementares compreendidos na fronteira de manufatura do poliestireno, devido em muito a decomposição da matéria orgânica nos reservatórios. Este processo corresponde a 5,5\% e 2,0\% das emissões do GPPS fóssil e parcialmente renovável respectivamente. De forma adicional, a queima de óleo combustível na refinaria, em consequência dos gases de combustão, representa isoladamente $5,5 \%$ do impacto em mudanças climáticas para o GPPS fóssil. Esta mesma queima de óleo quando analisada para o perfil de impacto do GPPS parcialmente renovável, representa a $1,9 \%$ das emissões de $\mathrm{CO}_{2 e q}$.

Ainda, os sistemas rodoviário e marítimo utilizados no transporte de matérias-primas emitem parcelas significativas de dióxido de carbono fóssil, oriundo da queima de combustível. O montante de gases de efeito estufa resultante do transporte é de 2,6\% para o GPPS fóssil e 6,4\% para o GPPS verde. Vale ressaltar, contudo, que o transporte transoceânico isoladamente abarca com 1,9\% das emissões do GPPS fóssil, sendo esta parcela de apenas 0,8\% para o GPPS verde. Esta diferença de representatividade tem origem, sobretudo, no sistema de transporte rodoviário utilizado tanto no processo de cultivo de cana-de-açúcar, quanto no transporte desta à usina de etanol e posteriormente à unidade de eteno.

Em termos gerais, o conjunto dos processos relacionados acima totaliza mais de $90 \%$ das emissões de dióxido de carbono equivalente identificadas nos perfis ambientais de ambos os poliestirenos cristal. 


\subsubsection{Depleção da Camada de Ozônio}

A depleção da camada de ozônio é um dos impactos que apresentou a maior similaridade de magnitude entre os perfis de desempenho do GPPS fóssil e verde. Esta afirmativa pode ser legitimada, uma vez que a diferença entre as emissões de CFC-11 eq não ultrapassou 8\%. A Tabela 75 expõe de forma quantitativa e percentual, a contribuição dos aspectos ambientais para ambos os poliestirenos cristal.

Tabela 75: Principais aspectos ambientais contribuintes para a categoria de Depleção da Camada de Ozônio na produção de GPPS

\begin{tabular}{|c|c|c|c|c|}
\hline \multirow{2}{*}{ Aspecto Ambiental } & \multicolumn{2}{|c|}{ GPPS Fóssil } & \multicolumn{2}{|c|}{$\begin{array}{l}\text { GPPS parcialmente } \\
\text { renovável }\end{array}$} \\
\hline & $\begin{array}{c}\text { Quantidade } \\
\text { [kg CFC-11 eq] }\end{array}$ & $\begin{array}{c}\text { Contribuição } \\
\text { [\%] }\end{array}$ & $\begin{array}{c}\text { Quantidade } \\
\text { [kg CFC-11 eq] }\end{array}$ & $\begin{array}{c}\text { Contribuição } \\
{[\%]}\end{array}$ \\
\hline Metano, bromotrifluor-, Halon 1301 & $5,00 \mathrm{E}-04$ & $80,1 \%$ & $4,00 E-04$ & $76,8 \%$ \\
\hline Metano, bromclorodifluor-, Halon 1211 & $1,00 \mathrm{E}-04$ & $18,6 \%$ & $1,00 \mathrm{E}-04$ & $21,5 \%$ \\
\hline Outros & $0,00 \mathrm{E}+00$ & $1,3 \%$ & $0,00 \mathrm{E}+00$ & $1,8 \%$ \\
\hline Total & 6,00E-04 & $100 \%$ & $5,00 \mathrm{E}-04$ & $100 \%$ \\
\hline
\end{tabular}

Conforme mostra a Tabela 75, a emissão de Halon 1301 e Halon 1211 na atmosfera é responsável por mais de $98 \%$ da carga ambiental referente à depleção da camada de ozônio. Sua origem advém dos processos de extração de petróleo internacional onshore, de tal modo que esta atividade representa $82 \%$ das emissões de CFC-11 eq para o GPPS fóssil e 80\% para o GPPS parcialmente renovável.

Tanto o Halon 1301 quanto o Halon 1211 são gases aplicados para prevenção de incêndios. Seu uso em locais de extração de petróleo ocorre em casos onde os limites de concentração de hidrocarbonetos no ar excede o máximo permitido para garantir a seguridade do processo. Nessas situações, Halon 1301 e 1211 são lançados no ambiente para reduzir os riscos de geração de fogo. Além das emissões decorrentes do uso, tais gases também são perdidos no sistema por vazamentos.

Esta origem das emissões de gases prejudiciais à camada de ozônio justifica, de forma clara, a diferença identificada entre os perfis de impacto, já que o eteno de origem renovável substitui parte dos insumos fósseis requeridos na manufatura do poliestireno cristal. 
Assim, a redução do consumo de petróleo, cuja extração é o principal emissor de Halon 1301 e 1211, na produção de insumos intermediários do GPPS verde minimiza o impacto deste produto em relação ao seu equivalente de origem fóssil.

\subsubsection{Acidificação Terrestre}

No que tange à acidificação terrestre, pode-se observar que a emissão de $\mathrm{SO}_{2 e q}$ no sistema de produto do GPPS parcialmente renovável é cerca de 240 vezes maior em relação àquela calculada para o GPPS fóssil. A Tabela 76 apresenta os valores de emissão para cada aspecto desta categoria de impacto, no que tange a manufatura de GPPS.

Tabela 76: Principais aspectos ambientais contribuintes para a categoria de Acidificação Terrestre na produção de GPPS

\begin{tabular}{lcccc}
\hline \multirow{2}{*}{ Aspecto Ambiental } & \multicolumn{2}{c}{ GPPS Fóssil } & \multicolumn{2}{c}{$\begin{array}{c}\text { GPPS parcialmente } \\
\text { renovável }\end{array}$} \\
\cline { 2 - 5 } & $\begin{array}{c}\text { Quantidade } \\
{\left[\mathbf{k g ~ S O}_{2 \mathrm{eq}}\right]}\end{array}$ & $\begin{array}{c}\text { Contribuição } \\
{[\%]}\end{array}$ & $\begin{array}{c}\text { Quantidade } \\
{\left[\mathbf{k g ~ S O}_{\text {2eq] }}\right]}\end{array}$ & $\begin{array}{c}\text { Contribuição } \\
{[\%]}\end{array}$ \\
\hline Dióxido de Enxofre & $\mathbf{2 , 6 2 \mathrm { E } + 0 0}$ & $\mathbf{6 3 , 9 \%}$ & $1,88 \mathrm{E}+00$ & $0,2 \%$ \\
\hline Óxidos de Nitrogênio & $1,39 \mathrm{E}+00$ & $34,0 \%$ & $\mathbf{9 , 6 7 E + 0 2}$ & $\mathbf{9 9 , 2 \%}$ \\
\hline Outros & $8,50 \mathrm{E}-02$ & $2,1 \%$ & $6,09 \mathrm{E}+00$ & $0,6 \%$ \\
\hline Total & $\mathbf{4 , 0 9 E + 0 0}$ & $\mathbf{1 0 0 \%}$ & $\mathbf{9 , 7 5 E + 0 2}$ & $\mathbf{1 0 0 \%}$ \\
\hline
\end{tabular}

As emissões de $\mathrm{SO}_{2}$ para o GPPS fóssil são resultantes, em grande parte, da queima e do processamento de gás natural para a remoção de gases ácidos, tal como ácido sulfúrico. Essas atividades, em conjunto, somam cerca de $66,7 \%$ das emissões para este impacto.

Ainda sobre o GPPS fóssil, é possível constatar que o transporte tem grande influência na emissão de $\mathrm{NO}_{x}$, pelo processo de combustão de óleo diesel. De acordo com as análises realizadas, 19,1\% da carga ambiental desta categoria está vinculada ao transporte utilizado por todo o sistema de produto. Vale destacar que as emissões decorrentes do transporte transoceânico, isoladamente, representam em torno de $18,1 \%$ do impacto de acidificação ( $94,8 \%$ com relação ao sistema de transporte). Por outro lado, as emissões de óxidos de nitrogênio representam 99,2\% da carga ambiental para o GPPS de origem parcialmente renovável. Diferentemente do GPPS 
fóssil, os processos de maior contribuição para este produto são a plantação e cultivo de cana, os quais aportam em 99\% das emissões. Isto por que, parte do sistema de colheita ocorre após queima prévia da plantação, ocasionando a emissão de óxidos de nitrogênio decorrentes da combustão incompleta e da presença de nitrogênio na biomassa.

Ainda, observa-se por meio da comparação dos resultados expostos na Tabela 76, que a quantidade de $\mathrm{SO}_{2}$ emitido para o GPPS verde apresenta uma pequena queda se comparada com o valor obtido para o GPPS fóssil. Esta redução é, fundamentalmente, em virtude da substituição da matéria-prima para a manufatura de eteno, visto que a extração e o tratamento do gás natural são os principais processos emissores deste poluente.

\subsubsection{Eutrofização em Água Doce}

Para a categoria de eutrofização em água doce, foi verificado o impacto ambiental ocasionado na produção de GPPS fóssil foi equivalente a $37 \%$ das emissões de $P_{\text {eq }}$ geradas pelo GPPS verde. Na Tabela 77 são apresentados os aspectos ambientais de maior contribuição para esta categoria.

Tabela 77: Principais aspectos ambientais contribuintes para a categoria de Eutrofização em Água Doce na produção de GPPS

\begin{tabular}{|c|c|c|c|c|}
\hline \multirow{2}{*}{ Aspecto Ambiental } & \multicolumn{2}{|c|}{ GPPS Fóssil } & \multicolumn{2}{|c|}{$\begin{array}{l}\text { GPPS parcialmente } \\
\text { renovável }\end{array}$} \\
\hline & $\begin{array}{c}\text { Quantidade } \\
{[\text { [kg P Peq }]}\end{array}$ & $\begin{array}{c}\text { Contribuição } \\
{[\%]}\end{array}$ & $\begin{array}{c}\text { Quantidade } \\
\text { [kg Peq] }\end{array}$ & $\begin{array}{c}\text { Contribuição } \\
{[\%]}\end{array}$ \\
\hline Fosfato & $2,03 \mathrm{E}-02$ & $99,2 \%$ & $4,64 \mathrm{E}-02$ & $84,3 \%$ \\
\hline Fósforo & 1,61E-04 & $0,8 \%$ & $8,66 \mathrm{E}-03$ & $15,7 \%$ \\
\hline Fósforo, total & $1,00 \mathrm{E}-06$ & $0,0 \%$ & $3,00 \mathrm{E}-06$ & $0,0 \%$ \\
\hline Total & $2,05 E-02$ & $100 \%$ & $5,50 \mathrm{E}-02$ & $100 \%$ \\
\hline
\end{tabular}

A emissão de fosfato em água doce compreende $99,2 \%$ da magnitude do impacto de eutrofização para o GPPS fóssil. O principal processo relacionado a este impacto, o qual contribui com $96,7 \%$ das emissões, é o envio de resíduos de carvão para aterro. 
Este carvão é utilizado com uma importante fonte de energia elétrica na matriz internacional, sendo, portanto, um impacto herdado da importação de petróleo e insumos.

Com menor representatividade, ainda para o GPPS fóssil, está o cultivo de cana, com $0,7 \%$ das emissões. Neste cenário, a cana é utilizada como fonte de geração de energia elétrica a partir de biomassa.

Para o GPPS de fonte parcialmente renovável, destaca-se como diferença, o aporte de superfosfato na agricultura para o cultivo de cana-de-açúcar requerida na produção de etanol. O uso deste fertilizante contribui com $18,9 \%$ das emissões. É este o principal elemento responsável pelo incremento do impacto do GPPS verde em relação do GPPS fóssil para esta categoria.

\subsubsection{Toxicidade Humana}

A toxicidade humana está entre as dez categorias onde a magnitude de impacto do GPPS parcialmente renovável apresentou um pior desempenho sobre aquela identificada para o GPPS fóssil. Em termos percentuais, a diferença entre as emissões de $1,4 \mathrm{DB}$ eq para esses materiais é da ordem de $11,4 \%$. A Tabela 78 lista os principais aspectos ambientais contribuintes para a categoria de impacto em questão.

Tabela 78: Principais aspectos ambientais contribuintes para a categoria de Toxicidade Humana na produção de GPPS

\begin{tabular}{|c|c|c|c|c|}
\hline \multirow{2}{*}{ Aspecto Ambiental } & \multicolumn{2}{|c|}{ GPPS Fóssil } & \multicolumn{2}{|c|}{$\begin{array}{l}\text { GPPS parcialmente } \\
\text { renovável }\end{array}$} \\
\hline & $\begin{array}{l}\text { Quantidade } \\
{\left[\mathrm{kg} 1,4-\mathrm{DB}_{\mathrm{eq}}\right]}\end{array}$ & $\begin{array}{c}\text { Contribuição } \\
\text { [\%] }\end{array}$ & $\begin{array}{l}\text { Quantidade } \\
\left.\text { [kg 1,4-DB }{ }_{\text {eq }}\right]\end{array}$ & $\begin{array}{c}\text { Contribuição } \\
{[\%]}\end{array}$ \\
\hline Bário & $5,45 \mathrm{E}+01$ & $70,5 \%$ & $4,40 \mathrm{E}+01$ & $50,5 \%$ \\
\hline Manganês & $1,13 \mathrm{E}+01$ & $14,6 \%$ & $1,08 \mathrm{E}+00$ & $1,2 \%$ \\
\hline Cadmio & $1,71 E-01$ & $0,2 \%$ & $1,82 E+01$ & $20,9 \%$ \\
\hline Outros & $1,13 E+01$ & $14,7 \%$ & $2,39 \mathrm{E}+01$ & $27,4 \%$ \\
\hline Total & $7,73 \mathrm{E}+01$ & $100 \%$ & $8,72 \mathrm{E}+01$ & $100 \%$ \\
\hline
\end{tabular}

O lançamento de íons metálicos em corpos hídricos resultante do tratamento de efluentes do processo de refino de petróleo nacional é responsável por $57,2 \%$ das emissões associadas a este impacto para o GPPS fóssil. 
Além dessas, $14 \%$ das emissões são resultado do sistema de tratamento de água das refinarias onshore de petróleo internacional. Nesta situação, a água tratada é injetada nos poços de petróleo, a fim de possibilitar a adequada extração do recurso, sendo previamente tratada, em especial, para garantir a integridade dos equipamentos da plataforma.

A disposição de resíduos de carvão mineral e linhata em aterros, também tem relevada importância neste impacto para o GPPS fóssil, contribuindo com 14,5\% das emissões de 1,4-DBeq. O motivo que fundamenta esta constatação é a composição química dos resíduos, a qual inclui manganês, bário, cadmio, dentre outros metais.

De forma similar, o processo de extração e processamento de petróleo é o aspecto de maior relevância para o GPPS parcialmente renovável, representando 39,5\% da carga ambiental nesta categoria, enquanto que o tratamento de água para as refinais onshore aporta com $11,9 \%$.

É notório, contudo, que parte significativa das emissões adicionais de 1,4-DBeq para o GPPS verde diz respeito a emissão de cadmio. Este poluente tem sua origem nos defensivos agrícolas utilizados na produção de cana-de-açúcar, processo que contribui com $29,4 \%$ das emissões.

\subsubsection{Formação de Oxidantes Fotoquímicos}

A formação de oxidantes fotoquímicos está entre as quatro categorias de impacto com a maior diferença de magnitude, uma vez que as emissões ocasionadas para a produção de GPPS parcialmente renovável foram cerca de 170 vezes superiores àquelas identificadas para o GPPS fóssil. A Tabela 79 traz de forma estruturada os aspectos ambientais de maior relevância para esta categoria de impacto.

As perdas de gás natural na sua extração, processamento e transporte, bem como a sua queima para a geração de energia em diferentes etapas do processo de obtenção de GPPS fóssil representam cerca de $67,8 \%$ das emissões de hidrocarbonetos à atmosfera.

De forma similar, o processamento do petróleo nas refinarias e a queima de combustíveis nestas, propiciam a emissão de compostos orgânicos voláteis e $\mathrm{NO}_{\mathrm{x}}$ resultantes de combustão incompleta dos óleos. Esses aspectos, em conjunto, somam $20,2 \%$ das emissões. 
Tabela 79: Principais aspectos ambientais contribuintes para a categoria de Formação de Oxidantes Fotoquímicos de GPPS

\begin{tabular}{|c|c|c|c|c|}
\hline \multirow{2}{*}{ Aspecto Ambiental } & \multicolumn{2}{|c|}{ GPPS Fóssil } & \multicolumn{2}{|c|}{$\begin{array}{c}\text { GPPS parcialmente } \\
\text { renovável }\end{array}$} \\
\hline & $\begin{array}{c}\text { Quantidade } \\
\text { [kg NMVOC] }\end{array}$ & $\begin{array}{c}\text { Contribuição } \\
{[\%]}\end{array}$ & $\begin{array}{c}\text { Quantidade } \\
\text { [kg NMVOC] }\end{array}$ & $\begin{array}{c}\text { Contribuição } \\
{[\%]}\end{array}$ \\
\hline Compostos Orgânicos Voláteis ${ }^{23}$ & $6,49 E+00$ & $64,5 \%$ & $4,80 \mathrm{E}+00$ & $0,3 \%$ \\
\hline Óxidos de nitrogênio & $2,49 \mathrm{E}+00$ & $24,7 \%$ & 1,73E+03 & $99,6 \%$ \\
\hline Etanol & $0,00 \mathrm{E}+00$ & $0,0 \%$ & $1,01 \mathrm{E}+00$ & $0,1 \%$ \\
\hline Outros & $1,09 \mathrm{E}+00$ & $10,8 \%$ & $1,01 \mathrm{E}+00$ & $0,1 \%$ \\
\hline Total & $1,01 \mathrm{E}+01$ & $100 \%$ & $1,73 E+03$ & $100 \%$ \\
\hline
\end{tabular}

Por fim, os transportes realizados no sistema de produto contribuem com $4 \%$ das emissões para o GPPS fóssil. Merece destaque nesse quesito, o transporte transoceânico, o qual aportou em 2,5\% das emissões, ou seja, $61 \%$ da carga referente ao transporte.

Apesar desses mesmos processos estarem entre os dez mais relevantes no sistema de produto do GPPS parcialmente renovável, a somatória dos impactos ambientais por eles causados não ultrapassa $0,5 \%$ da formação de oxidantes fotoquímicos. Esta distinção está relacionada à quantidade de óxidos de nitrogênio lançados para a atmosfera, a qual representa $99,6 \%$ das emissões. De forma análoga à categoria de acidificação terrestre, a plantação e o cultivo de cana-de-açúcar são as principais atividades contribuintes, devido à de queima de palha e a colheita preparação do solo. Este processo, isoladamente é responsável por 99,3\% das emissões de NMVOC.

\subsubsection{Formação de Material Particulado}

Em termos de formação de material particulado, o cenário encontrado em muito se assemelha às condições identificadas para a formação de foto-oxidantes, de tal modo que o GPPS fóssil apresentou um resultado equivalente a 0,2\% das emissões calculadas para o GPPS parcialmente renovável. A Tabela 80 indica quais os tipos de emissões foram mais significativas para esta categoria.

\footnotetext{
${ }^{23}$ Sem metano.
} 
Tabela 80: Principais aspectos ambientais contribuintes para a categoria de Formação de Material Particulado na produção de GPPS

\begin{tabular}{lcccc}
\hline \multirow{2}{*}{ Aspecto Ambiental } & \multicolumn{2}{c}{ GPPS Fóssil } & \multicolumn{2}{c}{$\begin{array}{c}\text { GPS parcialmente } \\
\text { renovável }\end{array}$} \\
\cline { 2 - 5 } & $\begin{array}{c}\text { Quantidade } \\
{[\mathbf{k g} \text { PM10 }]}\end{array}$ & $\begin{array}{c}\text { Contribuição } \\
{[\%]}\end{array}$ & $\begin{array}{c}\text { Quantidade } \\
{[\mathbf{k g} \text { PM10 }]}\end{array}$ & $\begin{array}{c}\text { Contribuição } \\
{[\%]}\end{array}$ \\
\hline Óxidos de nitrogênio & $\mathbf{5 , 4 7 E - 0 1}$ & $\mathbf{4 5 , 1 \%}$ & $\mathbf{3 , 8 0 E + 0 2}$ & $\mathbf{6 2 , 1 \%}$ \\
\hline Dióxidos de enxofre & $5,23 \mathrm{E}-01$ & $43,1 \%$ & $3,76 \mathrm{E}-01$ & $0,1 \%$ \\
\hline Particulados $<2,5 \mu \mathrm{m}$ & $6,60 \mathrm{E}-02$ & $5,4 \%$ & $2,19 \mathrm{E}+02$ & $35,8 \%$ \\
\hline Outros & $7,70 \mathrm{E}-02$ & $6,3 \%$ & $1,22 \mathrm{E}+01$ & $2,0 \%$ \\
\hline Total & $\mathbf{1 , 2 1 E + 0 0}$ & $\mathbf{1 0 0} \%$ & $\mathbf{6 , 1 1 E + 0 2}$ & $\mathbf{1 0 0} \%$ \\
\hline
\end{tabular}

Perdas e vazamentos de PM10 eq durante o refino do petróleo, bem como a queima de combustível para a realização dessa atividade, são responsáveis por 25,9\% das emissões do GPPS fóssil. De forma adicional, a queima de combustível para o transporte de matérias-primas, em âmbito nacional e internacional, seja por via terrestre ou marítima, lança na atmosfera óxidos de enxofre e de nitrogênio e particulados finos. Para o GPPS fóssil, os transportes que englobam o sistema de produto aportaram em emissões da ordem de 18,3\%, das quais 16,0\% dizem respeito ao transporte transoceânico.

Vale destacar, ainda, que dessulfurização do gás natural e demais tratamentos dados a este recurso contribuem, sobremaneira, com as emissões de óxidos de enxofre, resultando em 32,6\% das emissões de PM10 equivalente para o GPPS fóssil.

Por outro lado, os aspectos ambientais identificados para o GPPS verde apresentam configuração e magnitude distintas à de se sucedâneo. Este fato está vinculado, mais uma vez, à substituição de petróleo por eteno de cana-de-açúcar. Nesse sentido, cerca de 99,1\% das emissões de particulados contabilizadas no perfil de desempenho do GPPS verde são resultado da produção e cultivo de cana, justificando o acréscimo absoluto em comparação ao GPPS fóssil.

Esta emissão está relacionada à queima da plantação, a partir da qual são emitidos materiais particulados e $\mathrm{NO}_{x}$ decorrentes da presença de nitrogênio na matéria orgânica vegetal e em razão do processo de tratamento do solo, visto que o revolvimento do mesmo resulta na emissão de gases oriundos do processo de nitrificação. 


\subsubsection{Ecotoxicidade Terrestre}

Para a categoria de ecotoxicidade terrestre, a quantidade de poluentes emitidos durante a manufatura de GPPS parcialmente renovável foi mais de 60 vezes maior se comparado com o GPPS fóssil. Muito embora a relação de proporcionalidade seja representativa, o acréscimo em termos absolutos de emissão é da ordem de $5,68 \mathrm{~kg}$ 1,4-DBeq por tonelada produzida. A Tabela 81 apresenta os tipos de emissões mais significativas para este impacto.

Tabela 81: Principais aspectos ambientais contribuintes para a categoria de Ecotoxicidade Terrestre na produção de GPPS

\begin{tabular}{lcccc}
\hline \multirow{2}{*}{ Aspecto Ambiental } & \multicolumn{2}{c}{ GPPS Fóssil } & \multicolumn{2}{c}{$\begin{array}{c}\text { GPPS parcialmente } \\
\text { renovável }\end{array}$} \\
\cline { 2 - 5 } & $\begin{array}{c}\text { Quantidade } \\
\text { [kg 1,4-DBeq] }\end{array}$ & $\begin{array}{c}\text { Contribuição } \\
{[\%]}\end{array}$ & $\begin{array}{c}\text { Quantidade } \\
\text { [kg 1,4-DBeq] }\end{array}$ & $\begin{array}{c}\text { Contribuição } \\
{[\%]}\end{array}$ \\
\hline Diuron & $\mathbf{4 , 1 1 E - 0 2}$ & $\mathbf{4 3 , 8 \%}$ & $6,92 \mathrm{E}-01$ & $12,0 \%$ \\
\hline Ametryn & $2,99 \mathrm{E}-02$ & $31,8 \%$ & $2,42 \mathrm{E}-02$ & $0,4 \%$ \\
\hline Bromo & $1,14 \mathrm{E}-02$ & $12,2 \%$ & $1,11 \mathrm{E}-02$ & $0,2 \%$ \\
\hline Carbofuran & $0,00 \mathrm{E}+00$ & $0,0 \%$ & $\mathbf{4 , 8 7 E + 0 0}$ & $\mathbf{8 4 , 3 \%}$ \\
\hline Outros & $1,14 \mathrm{E}-02$ & $12,2 \%$ & $1,78 \mathrm{E}-01$ & $3,1 \%$ \\
\hline Total & $\mathbf{9 , 3 8 E - 0 2}$ & $\mathbf{1 0 0} \%$ & $\mathbf{5 , 7 8 E + 0 0}$ & $\mathbf{1 0 0} \%$ \\
\hline
\end{tabular}

As perdas de diuron e ametrina, ambos defensivos agrícolas, somam $75,6 \%$ das emissões do GPPS fóssil. Esses defensivos são aplicados na produção de biomassa para a geração de energia elétrica utilizada por todo o processo de manufatura desse GPPS, de tal modo que este processo representa $76,3 \%$ da carga ambienta nesta categoria. Outro componente de destaque nesta categoria de impacto para o poliestireno cristal de origem fóssil é o bromo, uma vez que este totaliza $12,2 \%$ da carga ambiental. Sua origem está atrelada à geração e ao tratamento dos efluentes da refinaria de petróleo.

Tendo em vista que a produção de GPPS parcialmente renovável requer a produção e o cultivo de cana, as emissões adicionais verificadas para este categoria de impacto estão baseadas, integralmente, ao aumento do uso de defensivos no sistema de produto.

Por esta razão, o processo de cultivo da cana-de-açúcar representa $98,5 \%$ do impacto de ecotoxicidade terrestre, enquanto que a produção de cana atribui outros $0,6 \%$. 


\subsubsection{Ecotoxicidade Aquática}

A ecotoxidade aquática é uma das dez categorias onde o impacto ocasionado pelo GPPS verde foi superior ao impacto do GPPS fóssil, com uma diferença da ordem de $53 \%$. A Tabela 82 expõe de forma quantitativa e percentual, a contribuição dos aspectos ambientais para ambos os poliestirenos cristal.

Tabela 82: Principais aspectos ambientais contribuintes para a categoria de Ecotoxicidade Aquática na produção de GPPS

\begin{tabular}{|c|c|c|c|c|}
\hline \multirow{2}{*}{ Aspecto Ambiental } & \multicolumn{2}{|c|}{ GPPS Fóssil } & \multicolumn{2}{|c|}{$\begin{array}{c}\text { GPPS parcialmente } \\
\text { renovável }\end{array}$} \\
\hline & $\begin{array}{c}\text { Quantidade } \\
\text { [kg 1,4-DBeq] }\end{array}$ & $\begin{array}{c}\text { Contribuição } \\
\text { [\%] }\end{array}$ & $\begin{array}{c}\text { Quantidade } \\
\text { [kg 1,4-DBeq] }\end{array}$ & $\begin{array}{c}\text { Contribuição } \\
{[\%]}\end{array}$ \\
\hline Bromo & $6,52 \mathrm{E}-01$ & $41,8 \%$ & $6,23 \mathrm{E}-01$ & $18,8 \%$ \\
\hline Bário & $3,56 \mathrm{E}-01$ & $22,8 \%$ & $2,87 E-01$ & $8,7 \%$ \\
\hline Hidrocarbonetos aromáticos & 1,59E-01 & $10,2 \%$ & 1,53E-01 & $4,6 \%$ \\
\hline Carbofuran & $0,00 \mathrm{E}+00$ & $0,0 \%$ & $1,46 \mathrm{E}+00$ & $43,9 \%$ \\
\hline Fósforo & $1,71 \mathrm{E}-02$ & $1,1 \%$ & 3,21E-01 & $9,7 \%$ \\
\hline Outros & $3,74 \mathrm{E}-01$ & $24,0 \%$ & 4,74E-01 & $14,3 \%$ \\
\hline Total & $1,56 \mathrm{E}+00$ & $100 \%$ & $3,31 \mathrm{E}+00$ & $100 \%$ \\
\hline
\end{tabular}

As emissões de íons metálicos e hidrocarbonetos aromáticos na produção de GPPS fóssil encontram-se pulverizadas, em especial, nas correntes líquidas emitidas no processo de refino de petróleo e na água tratada para uso no sistema de extração de petróleo onshore importado, os quais abarcam $76,6 \%$ das emissões.

O bromo identificado no efluente da refinaria é encontrado, usualmente, na água que é retirada junto ao petróleo, previamente ao seu refino. Em paralelo, a água tratada para injeção nos poços de petróleo onshore, também possui em sua composição íons metálicos que são lançados em meio aquoso, mediante o processo de descarte o lodo residual.

Observa-se que as quantidades de íons metálicos emitidos pelo GPPS fóssil e pelo GPPS verde em muito se assemelham, dado que os processos contribuintes são equivalentes. Deste modo, a representatividade das atividades de refino e extração de petróleo onshore somam 32,5\% das emissões de 1,4-DB eq para o GPPS parcialmente renovável. Entretanto, de forma adicional, é possível identificar para esta última a emissão de carbofuran e fósforo. 
Tais componentes são lançados em corpos hídricos durante o cultivo da cana de açúcar. Nesse âmbito, tal processamento é responsável por 52,4\% do impacto.

\subsubsection{Ocupação de Solo Agricultável}

A ocupação de solo agricultável, das categorias analisadas, foi aquela que apresentou o maior grau de diferença entre os poliestirenos cristal, com o GPPS parcialmente renovável obtendo um resultado vinte e seis mil vezes superior ao GPPS fóssil. A Tabela 83 apresenta os valores de emissão para cada aspecto desta categoria de impacto.

Tabela 83: Principais aspectos ambientais contribuintes para a categoria de Ocupação de Solo Agricultável na produção de GPPS

\begin{tabular}{lcccc}
\hline \multirow{2}{*}{ Aspecto Ambiental } & \multicolumn{2}{c}{ GPPS Fóssil } & \multicolumn{2}{c}{$\begin{array}{c}\text { GPS parcialmente } \\
\text { renovável }\end{array}$} \\
\cline { 2 - 5 } & $\begin{array}{c}\text { Quantidade } \\
{\left[\mathbf{m}^{2}\right]}\end{array}$ & $\begin{array}{c}\text { Contribuição } \\
{[\%]}\end{array}$ & $\begin{array}{c}\text { Quantidade } \\
{\left[\mathbf{m}^{2}\right]}\end{array}$ & $\begin{array}{c}\text { Contribuição } \\
{[\%]}\end{array}$ \\
\hline Ocupação, floresta, intensiva, normal & $\mathbf{7 , 2 3 E - 0 2}$ & $\mathbf{9 7 , 9 \%}$ & $5,79 \mathrm{E}-01$ & $0,0 \%$ \\
\hline Ocupação de solo não irrigado & $2,00 \mathrm{E}-04$ & $0,2 \%$ & $\mathbf{1 , 9 7 E + 0 3}$ & $\mathbf{9 9 , 9 \%}$ \\
\hline Outros & $1,40 \mathrm{E}-03$ & $1,8 \%$ & $8,73 \mathrm{E}-01$ & $0,0 \%$ \\
\hline Total & $\mathbf{7 , 3 8 E - 0 2}$ & $\mathbf{1 0 0 \%}$ & $\mathbf{1 , 9 7 E + 0 3}$ & $\mathbf{1 0 0 \%}$ \\
\hline
\end{tabular}

Para o GPPS fóssil, a ocupação de solo agricultável está relacionada, fundamentalmente, a plantação de espécies vegetais para a produção de carvão utilizado como fonte de energia térmica no processo de manufatura dos produtos importados que compõem o sistema de produto.

Já para o GPPS verde, o significativo incremento nos aspectos ambientais quantificados se deve à ocupação do solo para fins de cultivo de cana-de-açúcar, de tal modo que este processo, isoladamente, é responsável por $99,9 \%$ da carga ambiental deste produto.

Conclui-se, assim, que a substituição do gás natural por etanol de cana é o principal fator de interferência entre os desempenhos obtidos. 


\subsubsection{Transformação de Áreas Naturais}

$\mathrm{Na}$ categoria de transformação de áreas naturais, ambos os poliestirenos obtiveram praticamente o mesmo desempenho, com um resultado $7 \%$ superior para o GPPS fóssil que, em termos absolutos, representa um acréscimo de $0,0083 \mathrm{~m}^{2}$ modificados por tonelada de material produzido. A Tabela 84 reporta os principais aspectos pertencentes a esta categoria.

Tabela 84: Principais aspectos ambientais contribuintes para a categoria de Transformação de Áreas Naturais na produção de GPPS

\begin{tabular}{lcccc}
\hline Aspecto Ambiental & \multicolumn{2}{c}{ GPPS Fóssil } & \multicolumn{2}{c}{$\begin{array}{c}\text { GPPS parcialmente } \\
\text { renovável }\end{array}$} \\
\cline { 2 - 5 } & $\begin{array}{c}\text { Quantidade } \\
{\left[\mathbf{m}^{2}\right]}\end{array}$ & $\begin{array}{c}\text { Contribuição } \\
{[\%]}\end{array}$ & $\begin{array}{c}\text { Quantidade } \\
{\left[\mathbf{m}^{2}\right]}\end{array}$ & $\begin{array}{c}\text { Contribuição } \\
{[\%]}\end{array}$ \\
\hline Transformação de floresta & $\mathbf{1 , 2 1 E - 0 1}$ & $\mathbf{9 9 , 8 \%}$ & $\mathbf{1 , 1 1 E - 0 1}$ & $\mathbf{9 8 , 1 \%}$ \\
\hline Transformação de floresta extensiva & $2,00 \mathrm{E}-04$ & $0,2 \%$ & $2,20 \mathrm{E}-03$ & $1,9 \%$ \\
\hline Total & $\mathbf{1 , 2 1 E - 0 1}$ & $\mathbf{1 0 0 \%}$ & $\mathbf{1 , 1 3 E - 0 1}$ & $\mathbf{1 0 0 \%}$ \\
\hline
\end{tabular}

De acordo com as análises realizadas para este impacto, verificou-se que a ocupação do solo natural é resultado do sistema de geração de energia elétrica por hidroelétricas. Isto porque, as áreas ocupadas pelo represamento da usina, usualmente, englobam trechos de solos naturais, ou seja, regiões preservadas e com florestas. Nesse sentido, a geração de energia hidroelétrica representa 99,7\% deste impacto para o GPPS fóssil e 89,8\% da carga ambiental para o GPPS verde.

Vale lembrar que o modal de biomassa neste universo representou uma contribuição de $6,6 \%$ da matriz energética nacional para o período de referência.

Uma vez que a usina sucroalcooleira faz uso de seus resíduos para a produção de energia elétrica, a quantidade total de energia consumida diretamente da rede de distribuição nacional para a obtenção de eteno renovável é pouco inferior àquela quantificada para a extração, tratamento e transformação de gás natural em eteno.

Por tal razão, a magnitude dos aspectos derivados do GPPS verde em relação ao GPPS fóssil, para esta categoria de impacto, foi reduzida. Vale ressaltar nesse sentido que, a plantação de cana abarcou, exclusivamente, em ocupação de solos agrícolas, já que não é possível quantificar a transformação de áreas naturais relacionadas à expansão do cultivo desta cultura. 


\subsubsection{Depleção de Água}

A depleção de água na manufatura de GPPS parcialmente renovável é quatro vezes superior ao consumo deste recurso na produção de GPPS fóssil. A Tabela 85 corrobora tal afirmativa, por meio da apresentação dos principais aspectos ambientais identificados para esta categoria de impacto.

Tabela 85: Principais aspectos ambientais contribuintes para a categoria de Depleção de Água na produção de GPPS

\begin{tabular}{lcccc}
\hline \multirow{2}{*}{ Aspecto Ambiental } & \multicolumn{2}{c}{ GPPS Fóssil } & \multicolumn{2}{c}{$\begin{array}{c}\text { GPS parcialmente } \\
\text { renovável }\end{array}$} \\
\cline { 2 - 5 } & $\begin{array}{c}\text { Quantidade } \\
{\left[\mathbf{m}^{2}\right]}\end{array}$ & $\begin{array}{c}\text { Contribuição } \\
{[\%]}\end{array}$ & $\begin{array}{c}\text { Quantidade } \\
{\left[\mathbf{m}^{2}\right]}\end{array}$ & $\begin{array}{c}\text { Contribuição } \\
{[\%]}\end{array}$ \\
\hline Água de rio & $\mathbf{1 , 2 0 E + 0 1}$ & $\mathbf{8 9 , 9 \%}$ & $\mathbf{5 , 2 8 E + 0 1}$ & $\mathbf{9 5 , 6 \%}$ \\
\hline Água natural de origem não específica & $1,32 \mathrm{E}+00$ & $9,9 \%$ & $2,28 \mathrm{E}+00$ & $4,1 \%$ \\
\hline Outros & $3,18 \mathrm{E}-02$ & $0,2 \%$ & $1,22 \mathrm{E}-01$ & $0,2 \%$ \\
\hline Total & $\mathbf{1 , 3 4 E + 0 1}$ & $\mathbf{1 0 0} \%$ & $\mathbf{5 , 5 2 E + 0 1}$ & $\mathbf{1 0 0} \%$ \\
\hline
\end{tabular}

No que tange a produção de GPPS fóssil, verificou-se que mais de $99 \%$ do recurso advém de rios ou fontes naturais de água, cuja função de uso para o processo de manufatura é a transferência de energia térmica. Nesse âmbito, a produção de petroquímicos intermediários (eteno e benzeno) contribuiu $88,3 \%$ dos aspectos ambientais, enquanto que o refino de petróleo totalizou $8,4 \%$ da depleção do recurso. Já para o GPPS parcialmente renovável, observa-se que mais de $95,6 \%$ do recurso consumido tem sua origem em rios. Sua aplicação se destina em essência ao sistema de irrigação e cultivo de cana de açúcar, processos esses que totalizam 94,7\% da carga ambiental para este sistema de produto. Esta constatação justifica a supressão adicional de água pelo GPPS verde.

\subsubsection{Depleção de Recurso Fóssil}

A depleção de recurso fóssil está entre as três categorias no qual o desempenho obtido para o GPPS parcialmente renovável foi superior ao do GPPS fóssil, com uma diferença no resultado do indicador da ordem de 4,3\%. A Tabela 86 discrimina os recursos fósseis compreendidos nesta categoria. 
Tabela 86: Principais aspectos ambientais contribuintes para a categoria de Depleção de Recurso Fóssil na produção de GPPS

\begin{tabular}{lcccc}
\hline \multirow{2}{*}{ Aspecto Ambiental } & \multicolumn{2}{c}{ GPPS Fóssil } & \multicolumn{2}{c}{$\begin{array}{c}\text { GPS parcialmente } \\
\text { renovável }\end{array}$} \\
\cline { 2 - 5 } & $\begin{array}{c}\text { Quantidade } \\
{\left[\mathbf{m}^{3}\right]}\end{array}$ & $\begin{array}{c}\text { Contribuição } \\
{[\%]}\end{array}$ & $\begin{array}{c}\text { Quantidade } \\
{\left[\mathbf{m}^{3}\right]}\end{array}$ & $\begin{array}{c}\text { Contribuição } \\
{[\%]}\end{array}$ \\
\hline Petróleo cru & $\mathbf{6 , 7 6 \mathrm { E } + \mathbf { 0 2 }}$ & $\mathbf{6 4 , 7 \%}$ & $\mathbf{6 , 3 6 \mathrm { E } + \mathbf { 0 2 }}$ & $\mathbf{6 3 , 6 \%}$ \\
\hline Gás Natural & $3,64 \mathrm{E}+02$ & $34,8 \%$ & $3,55 \mathrm{E}+02$ & $35,5 \%$ \\
\hline Outros & $5,90 \mathrm{E}+00$ & $0,6 \%$ & $8,62 \mathrm{E}+00$ & $0,9 \%$ \\
\hline Total & $\mathbf{1 , 0 5 E + 0 3}$ & $\mathbf{1 0 0 , 0 \%}$ & $\mathbf{1 , 0 0 E + 0 3}$ & $\mathbf{1 0 0 , 0 \%}$ \\
\hline
\end{tabular}

O uso intensivo de combustível para a extração do petróleo, associado à necessidade de transporte e incorporação do mesmo no produto final, somam $64,3 \%$ da carga ambiental para o GPPS fóssil e 63,6\% para o GPPS verde. Dentre os aspectos mencionados, merece destaque a extração de petróleo internacional, uma vez que esta, sozinha, é responsável por aproximadamente 30\% da depleção para ambos os produtos.

A extração, tratamento e queima do gás natural requerido para a obtenção de vapor nas caldeiras também aporta, sobremaneira, com a redução de oferta de recursos fósseis, visto que em torno de $35 \%$ dos aspectos ambientais para esta categoria dizem respeito a estes processos.

É válido destacar que os percentuais de contribuição identificados para os processos antes relacionados e os respectivos recursos por ele consumidos, estão alinhados com os percentuais calculados para cada aspecto ambiental identificado na Tabela 86. Ou seja, a influência dessas atividades representa quase que a totalidade do impacto nesta categoria.

Ressalta-se, ainda, que a redução do consumo de recursos fósseis para o GPPS parcialmente renovável está diretamente associada a sua substituição desse por cana-de-açúcar. 


\subsection{PerfiL de IMPaCto ambiental do HIPS de ORIGEM FósSiL E PARCIALMENTE RENOVÁVEL}

A seguir, serão discutidas, com maior nível de detalhe, as treze categorias de impacto avaliadas para a manufatura de poliestireno de alto impacto de origem fóssil e parcialmente renovável.

Em se tratando dos fluxos de entrada e saída dos Inventários de Ciclo de Vida elaborados, verificou-se que os mesmos seguem às características descritas para o GPPS, com a introdução do polibutadieno, cuja matéria-prima advém de recurso fóssil.

Por esta razão, as produções de 1,0t HIPS fóssil e 1,0t de HIPS parcialmente renovável são constituídas por um conjunto específico de aspectos ambientais, em que as magnitudes e significâncias foram quantificadas com base no método ReCiPe Midpoint (H) V1.07.

Os resultados da Avaliação de Impactos Ambientais para cada um dos poliestirenos de alto impacto estão apresentados na Tabela 87.

Tabela 87: Perfil de Impacto Ambiental do HIPS fóssil e do HIPS parcialmente renovável

\begin{tabular}{lccc}
\hline Categorias de Impacto & Unidades & HIPS Fóssil & $\begin{array}{c}\text { HIPS parcialmente } \\
\text { renovável }\end{array}$ \\
\hline Mudanças Climáticas (MC) & $\mathrm{kg} \mathrm{CO}_{2 \text { eq }}$ & $1,58 \mathrm{E}+03$ & $3,27 \mathrm{E}+03$ \\
\hline Depleção da Camada de Ozônio (DO) & $\mathrm{kg} \mathrm{CFC-11} \mathrm{eq}$ & $5,02 \mathrm{E}-04$ & $4,65 \mathrm{E}-04$ \\
\hline Acidificação Terrestre (AT) & $\mathrm{kg} \mathrm{SO}_{2 \text { eq }}$ & $5,19 \mathrm{E}+00$ & $9,03 \mathrm{E}+02$ \\
\hline Eutrofização de Água Doce (EU) & $\mathrm{kg} \mathrm{P}$ eq & $2,24 \mathrm{E}-02$ & $5,43 \mathrm{E}-02$ \\
\hline Toxicidade Humana (TH) & $\mathrm{kg} 1,4-\mathrm{DB}$ eq & $7,16 \mathrm{E}+01$ & $1,05 \mathrm{E}+02$ \\
\hline Formação de Oxidantes Fotoquímicos (OF) & $\mathrm{kg} \mathrm{NMVOC}$ & $1,05 \mathrm{E}+01$ & $1,60 \mathrm{E}+03$ \\
\hline Formação de Material Particulado (MP) & $\mathrm{kg} \mathrm{PM10} \mathrm{eq}$ & $1,54 \mathrm{E}+00$ & $5,66 \mathrm{E}+02$ \\
\hline Ecotoxicidade Terrestre (ET) & $\mathrm{kg} 1,4-\mathrm{DB}$ eq & $8,43 \mathrm{E}-02$ & $5,34 \mathrm{E}+00$ \\
\hline Ecotoxicidade Aquática (EA) & $\mathrm{kg} \mathrm{1,4-DB}$ eq & $1,53 \mathrm{E}+00$ & $3,72 \mathrm{E}+00$ \\
\hline Ocupação de Solo Agricultável (SA) & $\mathrm{m}^{2}$ & $7,01 \mathrm{E}-02$ & $1,83 \mathrm{E}+03$ \\
\hline Transformação de Áreas Naturais (AN) & $\mathrm{m}^{2}$ & $1,04 \mathrm{E}-01$ & $9,64 \mathrm{E}-02$ \\
\hline Depleção de Água (DA) & $\mathrm{m}^{3}$ & $1,32 \mathrm{E}+01$ & $5,18 \mathrm{E}+01$ \\
\hline Depleção de Recurso Fóssil (DF) & $\mathrm{kg}$ oil eq & $9,34 \mathrm{E}+02$ & $8,92 \mathrm{E}+02$ \\
\hline
\end{tabular}


Com base nos dados constantes da Tabela 87, foi desenvolvido o Gráfico 6, no qual é realizada a comparação percentual entre desempenhos ambientais dos produtos em análise.

Conforme evidenciado em ambas as fontes de informação, os perfis ambientais apresentam distinções similares ao GPPS, de tal forma que o GPPS fóssil obteve magnitudes inferiores para dez das treze categorias de impactos estudadas.

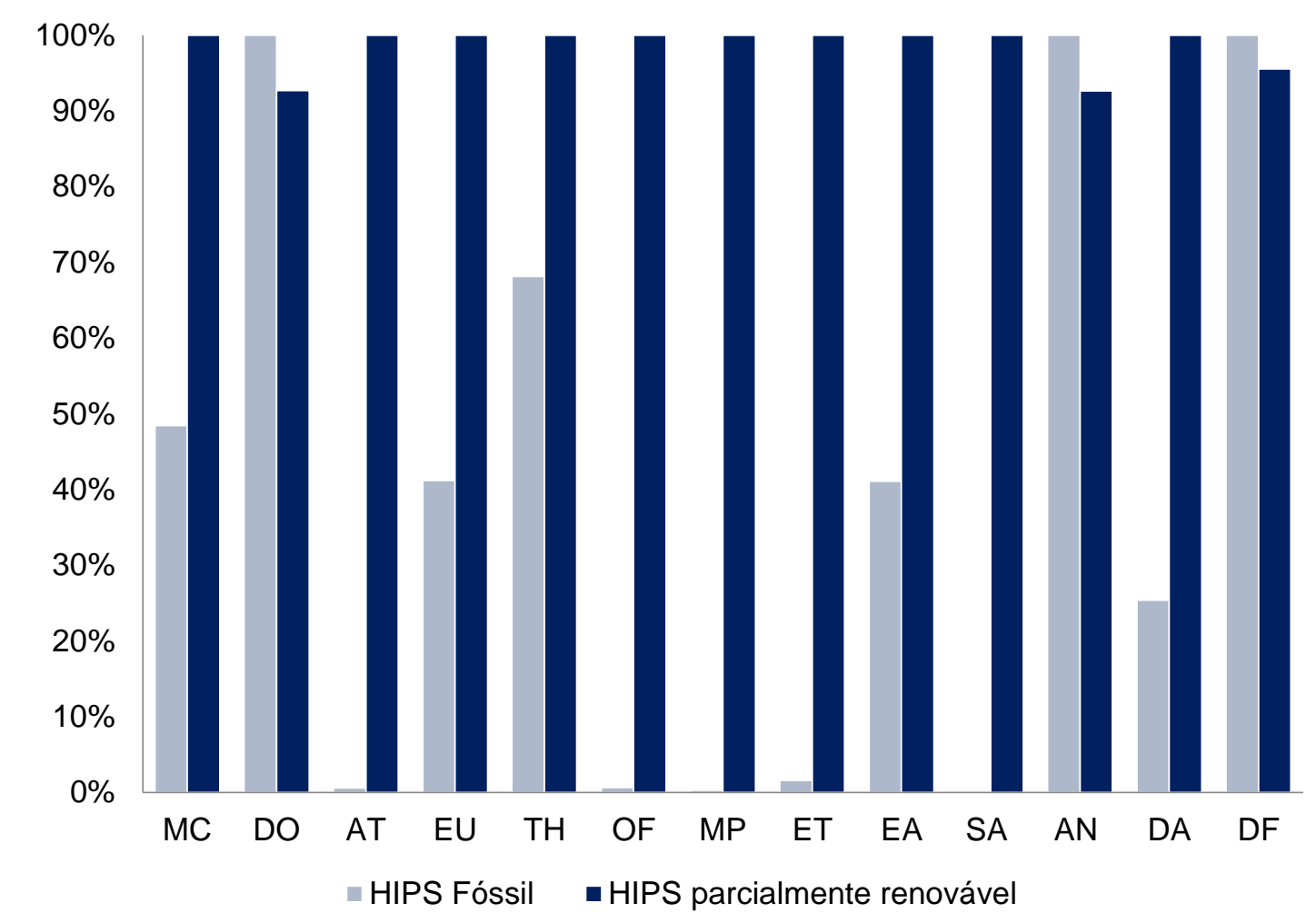

Gráfico 6: Comparação percentual dos desempenhos ambientais do HIPS fóssil e do HIPS parcialmente renovável.

\subsubsection{Mudanças Climáticas}

Para a categoria de mudanças climáticas, o processo de manufatura do HIPS fóssil e parcialmente renovável apresentou desempenho similar aquele identificado para o GPPS. A Tabela 88 apresenta os tipos de emissões mais significativas para este impacto. 
Tabela 88: Principais aspectos ambientais contribuintes para a categoria de Mudanças Climáticas na produção de HIPS

\begin{tabular}{lcccc}
\hline \multirow{2}{*}{ Aspecto Ambiental } & \multicolumn{2}{c}{ HIPS Fóssil } & \multicolumn{2}{c}{$\begin{array}{c}\text { HIPS parcialmente } \\
\text { renovável }\end{array}$} \\
\cline { 2 - 5 } & $\begin{array}{c}\text { Quantidade } \\
{\left[\mathbf{k g ~ C O}_{\mathbf{2}} \text { eq }\right]}\end{array}$ & $\begin{array}{c}\text { Contribuição } \\
{[\%]}\end{array}$ & $\begin{array}{c}\text { Quantidade } \\
{\left[\mathbf{k g ~ C O}_{2} \text { eq] }\right.}\end{array}$ & $\begin{array}{c}\text { Contribuição } \\
{[\%]}\end{array}$ \\
\hline Dióxido de carbono, fóssil & $\mathbf{1 , 3 0 \mathrm { E } + \mathbf { 0 3 }}$ & $\mathbf{8 1 , 9 \%}$ & $\mathbf{1 , 5 5 \mathrm { E } + \mathbf { 0 3 }}$ & $\mathbf{4 7 , 5 \%}$ \\
\hline Metano, fóssil & $2,04 \mathrm{E}+02$ & $12,9 \%$ & $1,71 \mathrm{E}+02$ & $5,2 \%$ \\
\hline $\begin{array}{l}\text { Dióxido de carbono, mudança de uso } \\
\text { do solo }\end{array}$ & $4,71 \mathrm{E}+01$ & $3,0 \%$ & $1,02 \mathrm{E}+03$ & $31,4 \%$ \\
\hline Metano, biogênico & $2,01 \mathrm{E}+01$ & $1,3 \%$ & $9,87 \mathrm{E}+01$ & $3,0 \%$ \\
\hline Monóxido de dinitrogênio & $2,63 \mathrm{E}+00$ & $0,2 \%$ & $2,50 \mathrm{E}+02$ & $7,6 \%$ \\
\hline Outros & $1,23 \mathrm{E}+01$ & $0,8 \%$ & $1,70 \mathrm{E}+02$ & $5,2 \%$ \\
\hline Total & $\mathbf{1 , 5 8 E + 0 3}$ & $\mathbf{1 0 0} \%$ & $\mathbf{3 , 2 7 E + 0 3}$ & $\mathbf{1 0 0} \%$ \\
\hline
\end{tabular}

Conforme mostram os resultados, a emissão de dióxido de carbono fóssil é o principal aspecto ambiental para ambos os HIPS.

No perfil de impacto do HIPS fóssil, a geração deste poluente está diretamente associada à extração, processamento, transporte e queima de gás natural, já que estas atividades correspondem a $64 \%$ das emissões. Em contrapartida, estes mesmos processos totalizam $29 \%$ da carga ambiental para o HIPS parcialmente renovável. Ressalta-se, ainda, que estas atividades contribuem, também, para a emissão de metano, segundo maior aspecto no sistema de produto do HIPS fóssil.

De forma complementar, somente o processamento do polibutadieno é responsável por $19,3 \%$ das emissões de gases feito estufa para o HIPS fóssil e 9,3\% para o HIPS parcialmente renovável. Isto porque, para produzir $1 \mathrm{~kg}$ de polibutadieno são necessários $1,209 \mathrm{~kg}$ de petróleo.

Ainda, $43,1 \%$ das emissões de $\mathrm{CO}_{2 \text { eq }}$ para o HIPS verde continuam a ser derivadas do processo de cultivo de cana-de-açúcar, justificando o acréscimo no lançamento de metano biogênico e monóxido de dinitrogênio $\left(\mathrm{N}_{2} \mathrm{O}\right)$ no seu sistema de produto em relação ao HIPS fóssil.

Para este último, a produção de energia hidroelétrica e o transporte correspondem, respectivamente, a 4,2\% e 2,0\% da carga ambiental. Merece especial atenção, nesse sentido, o transporte transoceânico, visto que este abarca com 1,3\% das emissões para o HIPS fóssil, sendo esta parcela de apenas $0,2 \%$ para o HIPS verde. 
Por fim, o impacto total devido ao uso de transporte para o HIPS verde compreende $2,7 \%$ das emissões de $\mathrm{CO}_{2 e q}$, complementando junto com os demais processos mencionados mais de $80 \%$ dos aspectos ambientais.

\subsubsection{Depleção da Camada de Ozônio}

A depleção da camada de ozônio é o impacto com a menor magnitude, em termos absolutos, para o perfil de desempenho do HIPS. A Tabela 89 apresenta a contribuição dos diferentes aspectos para esta categoria.

Tabela 89: Principais aspectos ambientais contribuintes para a categoria de Depleção da Camada de Ozônio na produção de HIPS

\begin{tabular}{lcccc}
\hline \multirow{2}{*}{ Aspecto Ambiental } & \multicolumn{2}{c}{ HIPS Fóssil } & \multicolumn{2}{c}{$\begin{array}{c}\text { HIPS parcialmente } \\
\text { renovável }\end{array}$} \\
\cline { 2 - 5 } & $\begin{array}{c}\text { Quantidade } \\
{[\mathbf{k g ~ C F C - 1 1} \text { eq] }}\end{array}$ & $\begin{array}{c}\text { Contribuição } \\
{[\%]}\end{array}$ & $\begin{array}{c}\text { Quantidade } \\
{[\mathbf{k g} \text { CFC-11 eq] }}\end{array}$ & $\begin{array}{c}\text { Contribuição } \\
{[\%]}\end{array}$ \\
\hline Metano, bromotrifluor-, Halon 1301 & $\mathbf{4 , 0 0 E - 0 4}$ & $\mathbf{7 9 , 8 \%}$ & $\mathbf{3 , 5 4 E - 0 4}$ & $\mathbf{7 6 , 2} \%$ \\
\hline Metano, bromodifluor-, Halon 1211 & $9,50 \mathrm{E}-05$ & $18,9 \%$ & $1,02 \mathrm{E}-04$ & $22,0 \%$ \\
\hline Outros & $7,00 \mathrm{E}-06$ & $1,3 \%$ & $8,00 \mathrm{E}-06$ & $1,8 \%$ \\
\hline Total & $\mathbf{5 , 0 2 E - 0 4}$ & $\mathbf{1 0 0 \%}$ & $\mathbf{4 , 6 5 E - 0 4}$ & $\mathbf{1 0 0 \%}$ \\
\hline
\end{tabular}

Observa-se a partir das informações da Tabela 89, que as principais emissões identificadas na manufatura do HIPS, para esta categoria, estão relacionadas ao uso e perdas de Halon 1301 e Halon 1211. Ambos os produtos são utilizados em sistemas de combate a incêndio nas refinarias de extração de petróleo internacional onshore, cujo processo representa $77 \%$ das emissões de CFC-11 eq para o HIPS fóssil e $70 \%$ para o HIPS parcialmente renovável.

\subsubsection{Acidificação Terrestre}

A respeito da acidificação terrestre, o impacto ocasionado pelo sistema de produto do HIPS parcialmente renovável é aproximadamente 170 vezes superior ao calculado para o HIPS fóssil. A Tabela 90 apresenta os valores de emissão de cada aspecto para esta categoria de impacto, no que tange a manufatura de HIPS. 
Tabela 90: Principais aspectos ambientais contribuintes para a categoria de Acidificação Terrestre na produção de HIPS

\begin{tabular}{lcccc}
\hline \multirow{2}{*}{ Aspecto Ambiental } & \multicolumn{2}{c}{ HIPS Fóssil } & \multicolumn{2}{c}{$\begin{array}{c}\text { HIPS parcialmente } \\
\text { renovável }\end{array}$} \\
\cline { 2 - 5 } & $\begin{array}{c}\text { Quantidade } \\
{\left[\mathbf{k g ~ S O}_{2 \text { eq }}\right]}\end{array}$ & $\begin{array}{c}\text { Contribuição } \\
{[\%]}\end{array}$ & $\begin{array}{c}\text { Quantidade } \\
{\left[\mathbf{k g ~ S O}_{2 \text { eq] }}\right]}\end{array}$ & $\begin{array}{c}\text { Contribuição } \\
{[\%]}\end{array}$ \\
\hline Dióxido de Enxofre & $\mathbf{3 , 4 8 E + 0 0}$ & $\mathbf{6 7 , 1 \%}$ & $2,80 \mathrm{E}+00$ & $0,3 \%$ \\
\hline Óxidos de Nitrogênio & $1,63 \mathrm{E}+00$ & $31,5 \%$ & $\mathbf{8 , 9 5 E + 0 2}$ & $\mathbf{9 9 , 1 \%}$ \\
\hline Outros & $7,60 \mathrm{E}-02$ & $1,5 \%$ & $5,63 \mathrm{E}+00$ & $0,6 \%$ \\
\hline Total & $\mathbf{5 , 1 9 E + 0 0}$ & $\mathbf{1 0 0 \%}$ & $\mathbf{9 , 0 3 E + 0 2}$ & $\mathbf{1 0 0 \%}$ \\
\hline
\end{tabular}

No que diz respeito ao HIPS fóssil, a queima e o processamento de gás natural $(47,7 \%)$, associados ao sistema de transporte (14,9\%) e a produção de polibutadieno $(26,8 \%)$ são os processos que mais aportam nas emissões de $\mathrm{SO}_{2 e q}$.

Neste contexto, vale salientar que a contribuição proveniente da manufatura do polibutadieno é composta pelo lançamento de $\mathrm{SO}_{2}, \mathrm{NO}_{x}$ e $\mathrm{NO}_{2}$ na atmosfera, cujas emissões advêm do consumo de gás natural utilizado como fonte de energia térmica, visto que $1 \mathrm{~kg}$ de polibutadieno consume cerca de $0,91 \mathrm{~m}^{3}$ de gás natural.

Já para o HIPS parcialmente renovável, 99,2\% da acidificação terrestre é resultado da plantação e do cultivo de cana-de-açúcar, pelos motivos discorridos na análise do GPPS.

\subsubsection{Eutrofização em Água Doce}

A eutrofização de corpos hídricos é uma das dez categorias onde o perfil desempenho do HIPS fóssil foi superior ao HIPS parcialmente renovável. A Tabela 91 discrimina os aspectos mais significativos para este impacto.

A partir dos resultados acima, observa-se que a emissão de fosfato em água doce compreende mais de $95 \%$ das emissões. O principal processo relacionado a esta categoria, para ambos os poliestirenos de alto impacto, é o envio de resíduos de carvão para aterro. No sistema de produto do HIPS fóssil, esta disposição final diz respeito a $84,5 \%$ da carga de $P_{\text {eq, }}$ enquanto que para o HIPS parcialmente renovável este processo representa $65,2 \%$. 
Tabela 91: Principais aspectos ambientais contribuintes para a categoria de Eutrofização em Água Doce na produção de HIPS

\begin{tabular}{lcccc}
\hline \multirow{2}{*}{ Aspecto Ambiental } & \multicolumn{2}{c}{ HIPS Fóssil } & \multicolumn{2}{c}{$\begin{array}{c}\text { HIPS parcialmente } \\
\text { renovável }\end{array}$} \\
\cline { 2 - 5 } & $\begin{array}{c}\text { Quantidade } \\
{[\mathbf{k g ~ P e q}]}\end{array}$ & $\begin{array}{c}\text { Contribuição } \\
{[\%]}\end{array}$ & $\begin{array}{c}\text { Quantidade } \\
{\left[\mathbf{k g} \mathbf{P}_{\text {eq }}\right]}\end{array}$ & $\begin{array}{c}\text { Contribuição } \\
{[\%]}\end{array}$ \\
\hline Fosfato & $\mathbf{2 , 2 2 E - 0 2}$ & $\mathbf{9 9 , 3 \%}$ & $\mathbf{5 , 1 6 E - 0 2}$ & $\mathbf{9 5 , 0 \%}$ \\
Fósforo & $1,50 \mathrm{E}-04$ & $0,6 \%$ & $2,70 \mathrm{E}-03$ & $5,0 \%$ \\
\hline Fósforo, total & $0,00 \mathrm{E}+00$ & $0,0 \%$ & $0,00 \mathrm{E}+00$ & $0,0 \%$ \\
\hline Total & $\mathbf{2 , 2 4 E - 0 2}$ & $\mathbf{1 0 0} \%$ & $\mathbf{5 , 4 3 E - 0 2}$ & $\mathbf{1 0 0 \%}$ \\
\hline
\end{tabular}

Com menor significância entre os processos está o cultivo de cana-de-açúcar, com 1,9\% das emissões para o produto de origem fóssil e 17,6\% para o HIPS parcialmente renovável. Neste cenário, a cana é utilizada tanto para a geração de energia elétrica quanto como insumo para a manufatura de eteno, utilizado na produção de HIPS verde.

\subsubsection{Toxicidade Humana}

No que tange a toxicidade humana, o sistema de produto do HIPS fóssil obteve uma magnitude da ordem de $68 \%$ do total inventariado para o HIPS parcialmente renovável. A Tabela 92 lista os principais aspectos ambientais contribuintes para a categoria de impacto em questão.

Tabela 92: Principais aspectos ambientais contribuintes para a categoria de Toxicidade Humana na produção de HIPS

\begin{tabular}{|c|c|c|c|c|}
\hline \multirow{2}{*}{ Aspecto Ambiental } & \multicolumn{2}{|c|}{ HIPS Fóssil } & \multicolumn{2}{|c|}{$\begin{array}{l}\text { HIPS parcialmente } \\
\text { renovável }\end{array}$} \\
\hline & $\begin{array}{c}\text { Quantidade } \\
{\left[\mathrm{kg} 1,4-D B_{\text {eq }}\right]}\end{array}$ & $\begin{array}{c}\text { Contribuição } \\
\text { [\%] }\end{array}$ & $\begin{array}{c}\text { Quantidade } \\
\left.\text { [kg 1,4-DB }{ }_{\text {eq }}\right]\end{array}$ & $\begin{array}{c}\text { Contribuição } \\
\text { [\%] }\end{array}$ \\
\hline Bário & $4,82 \mathrm{E}+01$ & $67,3 \%$ & $3,91 \mathrm{E}+01$ & $37,2 \%$ \\
\hline Manganês & $1,08 \mathrm{E}+01$ & $15,1 \%$ & $2,06 \mathrm{E}+01$ & $19,7 \%$ \\
\hline Cadmio & $3,00 \mathrm{E}-03$ & $0,0 \%$ & $1,69 \mathrm{E}+01$ & $16,0 \%$ \\
\hline Outros & $1,26 \mathrm{E}+01$ & $17,6 \%$ & $2,85 E+01$ & $27,1 \%$ \\
\hline Total & $7,16 \mathrm{E}+01$ & $100 \%$ & $1,05 E+02$ & $100 \%$ \\
\hline
\end{tabular}

Para ambos os HIPS, o lançamento de bário em corpos hídricos foi o principal aspecto identificado nos perfis de impacto. 
A emissão deste e de outros íons metálicos é resultante, em especial, do tratamento de efluentes da etapa de refino de petróleo, em que $54,5 \%$ dos poluentes associados a este processo são emitidos para o HIPS fóssil e 28,5\% para o HIPS parcialmente renovável.

Além dessas, 13,7\% da carga ambiental do HIPS fóssil e 8,7\% dos aspectos do HIPS verde são em decorrência do sistema de tratamento de água das refinarias onshore de petróleo internacional.

É válido salientar, ainda, que parte expressiva das emissões adicionais de 1,4-DBeq para o HIPS verde diz respeito a emissão de cadmio presente em defensivos agrícolas. Isto posto, o processo de produção de cana-de-açúcar compreende 22,6\% das emissões quantificadas para a toxicidade humana neste produto.

Finalmente, a disposição de resíduos de carvão mineral e linhata em aterros, também tem relevada importância neste impacto para ambos os materiais, de tal modo que a sua contribuição representa $15,0 \%$ do lançamento de 1,4-DB eq para o HIPS fóssil e 19,1\% para o HIPS parcialmente renovável.

\subsubsection{Formação de Oxidantes Fotoquímicos}

A formação de oxidantes fotoquímicos é a quinta categoria com a maior diferença de magnitude entre o HIPS de origem fóssil e o parcialmente renovável. A Tabela 93 traz de forma estruturada os aspectos ambientais de maior relevância para este impacto.

Tabela 93: Principais aspectos ambientais contribuintes para a categoria de Formação de Oxidantes Fotoquímicos de HIPS

\begin{tabular}{|c|c|c|c|c|}
\hline \multirow{2}{*}{ Aspecto Ambiental } & \multicolumn{2}{|c|}{ HIPS Fóssil } & \multicolumn{2}{|c|}{$\begin{array}{l}\text { HIPS parcialmente } \\
\text { renovável }\end{array}$} \\
\hline & $\begin{array}{c}\text { Quantidade } \\
\text { [kg NMVOC] }\end{array}$ & $\begin{array}{c}\text { Contribuição } \\
{[\%]}\end{array}$ & $\begin{array}{l}\text { Quantidade } \\
\text { [kg NMVOC] }\end{array}$ & $\begin{array}{c}\text { Contribuição } \\
\text { [\%] }\end{array}$ \\
\hline 24Compostos Orgânicos Voláteis ${ }^{25}$ & $6,51 E+00$ & $61,9 \%$ & $4,95 \mathrm{E}+00$ & $0,3 \%$ \\
\hline Óxidos de nitrogênio & $2,91 \mathrm{E}+00$ & $27,7 \%$ & $1,60 \mathrm{E}+03$ & $99,6 \%$ \\
\hline Etanol & $0,00 \mathrm{E}+00$ & $0,0 \%$ & $9,37 \mathrm{E}-01$ & $0,1 \%$ \\
\hline Outros & $1,09 \mathrm{E}+00$ & $10,4 \%$ & $1,02 E+00$ & $0,1 \%$ \\
\hline Total & $1,05 \mathrm{E}+01$ & $100 \%$ & $1,60 \mathrm{E}+03$ & $100 \%$ \\
\hline
\end{tabular}

24 Sem metano 
As atividades de obtenção, tratamento e transporte do gás natural e a produção de polibutadieno são os processos de maior significância nas emissões de NMVOC no sistema de produto do HIPS fóssil, aportando em 57,6\% e 13,8\% da carga ambiental, respectivamente.

No que tange a manufatura da borracha, ressalta-se que as emissões de NMVOC estão vinculadas a queima de combustível fóssil requerido para a geração de vapor no processo. De forma similar, o processamento de petróleo nas refinarias e a queima de combustíveis nestas somam 19,8\% dos aspectos para o HIPS fóssil, sendo o sistema de transporte responsável por outros 4,6\% da carga ambiental.

Apesar desses mesmos processos estarem entre os dez mais relevantes no sistema de produto do HIPS parcialmente renovável, o total dos aspectos ambientais por eles causados não ultrapassa 0,5\%. Nesse sentido, 99,2\% do impacto na formação de oxidantes fotoquímicos está relacionado à quantidade de óxidos de nitrogênio emitidos nos processos de plantação e cultivo de cana-de-açúcar.

\subsubsection{Formação de Material Particulado}

A respeito da formação de material particulado é possível constatar que o HIPS parcialmente renovável possui um valor absoluto de emissões 366 vezes superior ao identificado no sistema de produto do HIPS fóssil. A Tabela 94 expõe as contribuições mássicas e percentuais para os principais aspectos ambientais quantificados nesta categoria.

Tabela 94: Principais aspectos ambientais contribuintes para a categoria de Formação de Material Particulado na produção de HIPS

\begin{tabular}{|c|c|c|c|c|}
\hline \multirow{2}{*}{ Aspecto Ambiental } & \multicolumn{2}{|c|}{ HIPS Fóssil } & \multicolumn{2}{|c|}{$\begin{array}{l}\text { HIPS parcialmente } \\
\text { renovável }\end{array}$} \\
\hline & $\begin{array}{l}\text { Quantidade } \\
\text { [kg PM10 eq] }\end{array}$ & $\begin{array}{c}\text { Contribuição } \\
{[\%]}\end{array}$ & $\begin{array}{l}\text { Quantidade } \\
\text { [kg PM10 eq] }\end{array}$ & $\begin{array}{c}\text { Contribuição } \\
{[\%]}\end{array}$ \\
\hline Dióxidos de enxofre & $6,96 \mathrm{E}-01$ & $45,1 \%$ & $5,60 \mathrm{E}-01$ & $0,1 \%$ \\
\hline Óxidos de nitrogênio & 6,41E-01 & $41,6 \%$ & 3,52E+02 & $62,1 \%$ \\
\hline Particulados $<2,5 \mu \mathrm{m}$ & $8,80 \mathrm{E}-02$ & $5,7 \%$ & $2,02 \mathrm{E}+02$ & $35,8 \%$ \\
\hline Outros & 1,18E-01 & $7,6 \%$ & $1,14 \mathrm{E}+01$ & $2,0 \%$ \\
\hline Total & $1,54 \mathrm{E}+00$ & $100 \%$ & $5,66 \mathrm{E}+02$ & $100 \%$ \\
\hline
\end{tabular}


O processamento e transporte do gás natural consumido como matéria-prima e recursos energético são os processos de maior relevância nas emissões de PM10 eq para o HIPS fóssil, visto que representam $41,9 \%$ da carga ambiental.

De forma complementar, a queima de combustível no transporte transoceânico e rodoviário, bem como na manufatura de polibutadieno contribui, respectivamente, com $12,1 \%, 2,9 \%$ e 26,9\% do impacto na formação de material particulado no sistema de produto do HIPS fóssil. As emissões nestes processos são derivadas, em especial, do lançamento de óxidos de enxofre e de nitrogênio, além de particulados finos.

Muito embora esses processos também aportem em emissões no processo de fabricação do HIPS parcialmente renovável, a soma das suas contribuições totaliza cerca de $0,3 \%$ da carga ambiental para este produto. Isto porque, a etapa de cultivo de cana-de-açúcar, devido às queimas e preparações de solo, liberam para a atmosfera $99,0 \%$ das emissões de PM10 eq.

De forma menos significativa, encontra-se o processo de manufatura de etanol hidratado, em que o intensivo de consumo de energia representa $0,7 \%$ do impacto ocasionado pelo HIPS verde para a formação de material particulado.

\subsubsection{Ecotoxicidade Terrestre}

Sobre a ecotoxicidade terrestre, verifica-se que o HIPS fóssil apresentou um melhor desempenho ambiental em relação ao HIPS parcialmente renovável. Esta afirmativa pode ser corroborada com as informações descritas na Tabela 95.

Tabela 95: Principais aspectos ambientais contribuintes para a categoria de Ecotoxicidade Terrestre na produção de HIPS

\begin{tabular}{lcccc}
\hline Aspecto Ambiental & \multicolumn{2}{c}{ HIPS Fóssil } & \multicolumn{2}{c}{$\begin{array}{c}\text { HIPS parcialmente } \\
\text { renovável }\end{array}$} \\
\hline Diuron & $\begin{array}{c}\text { Quantidade } \\
\text { [kg 1,4-DBeq] }\end{array}$ & $\begin{array}{c}\text { Contribuição } \\
{[\%]}\end{array}$ & $\begin{array}{c}\text { Quantidade } \\
{[\mathbf{k g} \mathbf{1 , 4 - D B e q ]}}\end{array}$ & $\begin{array}{c}\text { Contribuição } \\
{[\%]}\end{array}$ \\
\hline Ametryn & $\mathbf{3 , 5 3 E - 0 2}$ & $\mathbf{4 1 , 9 \%}$ & $6,37 \mathrm{E}-01$ & $11,9 \%$ \\
\hline Bromo & $2,57 \mathrm{E}-02$ & $30,4 \%$ & $2,04 \mathrm{E}-02$ & $0,4 \%$ \\
\hline Carbofuran & $1,09 \mathrm{E}-02$ & $12,9 \%$ & $1,06 \mathrm{E}-02$ & $0,2 \%$ \\
\hline Outros & $0,00 \mathrm{E}+00$ & $0,0 \%$ & $\mathbf{4 , 5 1 E + 0 0}$ & $\mathbf{8 4 , 4 \%}$ \\
\hline Total & $\mathbf{1 , 2 4 \mathrm { E } - 0 2}$ & $14,7 \%$ & $1,67 \mathrm{E}-01$ & $3,1 \%$ \\
\hline & $\mathbf{8 , 4 3 E}-\mathbf{0 2}$ & $\mathbf{1 0 0} \%$ & $\mathbf{5 , 3 4 E + 0 0}$ & $\mathbf{1 0 0 \%}$ \\
\hline
\end{tabular}


A perda dos defensivos agrícolas diuron e ametrina totaliza 72,3\% das emissões do HIPS fóssil. Conforme mencionado anteriormente, esses defensivos são aplicados na produção de biomassa utilizada na geração de energia elétrica, de tal modo que este processo representa $73,0 \%$ do impacto neste sistema de produto.

Outro aspecto ambiental significativo identificado para o HIPS fóssil é a emissão de bromo, cuja contribuição chega a 12,9\%, em resposta às características do efluente da refinaria de petróleo que contribui com $12,0 \%$ da carga ambiental nesta categoria. Por outro lado, observa-se que a aplicação do defensivo agrícola carbofuran é o principal aspecto do perfil de impacto do HIPS parcialmente renovável. Nesse sentido, a produção e o cultivo de cana contabilizam 99,0\% das emissões de 1,4-DBeq.

\subsubsection{Ecotoxicidade Aquática}

De acordo com a caracterização dos aspectos ambientais para o ciclo de vida do poliestireno de alto impacto, a magnitude da categoria de ecotoxicidade aquática para o HIPS fóssil equivale a $41 \%$ daquela quantificada para o HIPS parcialmente renovável. As contribuições para este impacto podem ser verificados na Tabela 96.

Tabela 96: Principais aspectos ambientais contribuintes para a categoria de Ecotoxicidade Aquática na produção de HIPS

\begin{tabular}{|c|c|c|c|c|}
\hline \multirow{2}{*}{ Aspecto Ambiental } & \multicolumn{2}{|c|}{ HIPS Fóssil } & \multicolumn{2}{|c|}{$\begin{array}{l}\text { HIPS parcialmente } \\
\text { renovável }\end{array}$} \\
\hline & $\begin{array}{c}\text { Quantidade } \\
\text { [kg 1,4-DBeq] }\end{array}$ & $\begin{array}{c}\text { Contribuição } \\
{[\%]}\end{array}$ & $\begin{array}{c}\text { Quantidade } \\
\text { [kg 1,4-DBeq] }\end{array}$ & $\begin{array}{c}\text { Contribuição } \\
{[\%]}\end{array}$ \\
\hline Bromo & $6,20 \mathrm{E}-01$ & $40,6 \%$ & $5,94 \mathrm{E}-01$ & $16,0 \%$ \\
\hline Bário & $3,14 \mathrm{E}-01$ & $20,6 \%$ & $2,55 \mathrm{E}-01$ & $6,9 \%$ \\
\hline Hidrocarbonetos aromáticos & 1,42E-01 & $9,3 \%$ & 1,35E-01 & $3,6 \%$ \\
\hline Carbofuran & $0,00 \mathrm{E}+00$ & $0,0 \%$ & 1,35E+00 & $36,3 \%$ \\
\hline Íons de níquel & $1,88 \mathrm{E}-01$ & $12,3 \%$ & $3,63 \mathrm{E}-01$ & $9,8 \%$ \\
\hline Outros & $2,63 \mathrm{E}-01$ & $17,2 \%$ & $1,02 \mathrm{E}+00$ & $27,5 \%$ \\
\hline Total & $1,53 \mathrm{E}+00$ & $100 \%$ & $3,72 E+00$ & $100 \%$ \\
\hline
\end{tabular}

As emissões de íons de bromo, bário e níquel contribuem com 73,5\% da quantidade de 1,4-DBeq lançados em meio aquoso para o HIPS fóssil. 
Segundo a análise do inventário, esses poluentes são gerados no sistema de tratamento da água utilizada durante a extração de petróleo onshore, cujo processo abarca com $52,7 \%$ das emissões.

De forma adicional, parte do bromo e hidrocarbonetos emitidos tem sua origem nas correntes de efluentes da planta refino de petróleo, a qual representa 16,6\% da carga ambiental para o HIPS fóssil.

Assim como para o GPPS, o montante de íons metálicos emitidos pelo HIPS fóssil e parcialmente renovável em muito se assemelham, dado que os processos contribuintes são os mesmos. Deste modo, a representatividade das atividades de refino e de extração de petróleo onshore somam 20,3\% das emissões de 1,4-DBeq para o HIPS verde.

Todavia, observa-se que somente a emissão de carbofuran totaliza $36,3 \%$ da ecotoxicidade terrestre para o HIPS parcialmente renovável. Este defensivo é lançado em corpos hídricos durante a plantação e cultivo da cana de açúcar, de tal modo que estes processos aportam em $43,3 \%$ da carga ambiental para este impacto.

\subsubsection{Ocupação de Solo Agricultável}

A ocupação de solo agricultável é a categoria com a maior diferença entre o perfil de desempenho do HIPS fóssil e do HIPS parcialmente renovável. A Tabela 97 expõe de forma quantitativa e percentual a contribuição dos aspectos ambientais para ambos os poliestirenos de alto impacto.

Tabela 97: Principais aspectos ambientais contribuintes para a categoria de Ocupação de Solo Agricultável na produção de HIPS

\begin{tabular}{lcccc} 
Aspecto Ambiental & \multicolumn{2}{c}{ HIPS Fóssil } & \multicolumn{2}{c}{$\begin{array}{c}\text { HIPS parcialmente } \\
\text { renovável }\end{array}$} \\
\hline Ocupação, floresta, intensiva, normal & $\begin{array}{c}\text { Quantidade } \\
{\left[\mathbf{m}^{2}\right]}\end{array}$ & $\begin{array}{c}\text { Contribuição } \\
{[\%]}\end{array}$ & $\begin{array}{c}\text { Quantidade } \\
{\left[\mathbf{m}^{2}\right]}\end{array}$ & $\begin{array}{c}\text { Contribuição } \\
{[\%]}\end{array}$ \\
\hline Ocupação, floresta, intensiva & $1,70 \mathrm{E}-03$ & $\mathbf{9 5 , 5 \%}$ & $5,36 \mathrm{E}-01$ & $0,0 \%$ \\
\hline Ocupação de solo não irrigado & $1,00 \mathrm{E}-04$ & $2,4 \%$ & $8,04 \mathrm{E}-01$ & $0,0 \%$ \\
\hline Outros & $1,30 \mathrm{E}-03$ & $1,9 \%$ & $5,00 \mathrm{E}-03$ & $0,0 \%$ \\
\hline Total & $\mathbf{7 , 0 1 E - 0 2}$ & $\mathbf{1 0 0} \%$ & $\mathbf{1 , 8 3 E + 0 3}$ & $\mathbf{1 0 0} \%$ \\
\hline
\end{tabular}


Conforme apresentado na Tabela 97, a ocupação de florestas é o principal aspecto identificado para a manufatura de HIPS fóssil. O uso destas áreas está associado à produção de carvão vegetal requerido no processo de manufatura de insumos importados, tal como o polibutadieno, sendo este responsável por $96,7 \%$ da ocupação de áreas agricultáveis no sistema de produto do HIPS fóssil. É por esta razão que a representatividade deste impacto em termos absolutos é diminuta.

No que tange ao HIPS parcialmente renovável, o aumento significativo nos aspectos ambientais quantificados é devido, fundamentalmente, à ocupação do solo para cultivo de cana-de-açúcar, de tal modo que este processo corresponde a 99,9\% da carga ambiental deste produto.

\subsubsection{Transformação de Áreas Naturais}

A transformação de áreas naturais está entre as três categorias onde a produção de HIPS fóssil obteve um desempenho inferior ao HIPS parcialmente renovável, mesmo que pequeno. A Tabela 98 mostra as contribuições para esta categoria de impacto.

Tabela 98: Principais aspectos ambientais contribuintes para a categoria de Transformação de Áreas Naturais na produção de HIPS

\begin{tabular}{lcccc}
\hline \multirow{2}{*}{ Aspecto Ambiental } & \multicolumn{2}{c}{ HIPS Fóssil } & \multicolumn{2}{c}{$\begin{array}{c}\text { HIPS parcialmente } \\
\text { renovável }\end{array}$} \\
\cline { 2 - 5 } & $\begin{array}{c}\text { Quantidade } \\
{\left[\mathbf{m}^{2}\right]}\end{array}$ & $\begin{array}{c}\text { Contribuição } \\
{[\%]}\end{array}$ & $\begin{array}{c}\text { Quantidade } \\
{\left[\mathbf{m}^{2}\right]}\end{array}$ & $\begin{array}{c}\text { Contribuição } \\
{[\%]}\end{array}$ \\
\hline Transformação de floresta & $1,04 \mathrm{E}-01$ & $100,0 \%$ & $9,64 \mathrm{E}-02$ & $100,0 \%$ \\
\hline Total & $\mathbf{1 , 0 4 E - 0 1}$ & $\mathbf{1 0 0 \%}$ & $\mathbf{9 , 6 4 E - 0 2}$ & $\mathbf{1 0 0 \%}$ \\
\hline
\end{tabular}

Em ambos os sistemas de produto, a transformação de áreas naturais está vinculada ao consumo de energia hidroelétrica computada para a produção do poliestireno de alto impacto. Nesse sentido, a totalidade deste impacto para o HIPS fóssil é resultado da geração de energia hidroelétrica, enquanto que este mesmo processo representa $89,2 \%$ para o HIPS parcialmente renovável.

De forma análoga ao GPPS, o melhor desempenho do HIPS verde diz respeito ao menor consumo de energia elétrica da matriz nacional durante o seu ciclo de vida, visto que a indústria sucroalcooleira faz uso de seus resíduos para a produção in loco de energia. 


\subsubsection{Depleção de Água}

A respeito da depleção de água, observa-se que o HIPS fóssil apresentou uma magnitude de impacto quatro vezes inferior à calculada para o HIPS parcialmente renovável. A Tabela 99 traz de forma estruturada os aspectos ambientais de maior relevância para esta categoria de impacto.

Tabela 99: Principais aspectos ambientais contribuintes para a categoria de Depleção de Água na produção de HIPS

\begin{tabular}{lcccc}
\hline Aspecto Ambiental & \multicolumn{2}{c}{ HIPS Fóssil } & \multicolumn{2}{c}{$\begin{array}{c}\text { HIPS parcialmente } \\
\text { renovável }\end{array}$} \\
\hline Água de rio & $\begin{array}{c}\text { Quantidade } \\
{\left[\mathrm{m}^{2}\right]}\end{array}$ & $\begin{array}{c}\text { Contribuição } \\
{[\%]}\end{array}$ & $\begin{array}{c}\text { Quantidade } \\
{\left[\mathbf{m}^{2}\right]}\end{array}$ & $\begin{array}{c}\text { Contribuição } \\
{[\%]}\end{array}$ \\
\hline Água natural de origem não específica & $\mathbf{1 , 1 2 \mathrm { E } + \mathbf { 0 1 }}$ & $\mathbf{8 5 , 4 \%}$ & $\mathbf{4 , 9 0 \mathrm { E } + \mathbf { 0 1 }}$ & $\mathbf{9 4 , 4 \%}$ \\
\hline Outros & $\mathbf{3 , 1 9 \mathrm { E } - 0 2}$ & $\mathbf{0 , 2} \%$ & $\mathbf{1 , 1 5 \mathrm { E } - 0 1}$ & $0,2 \%$ \\
\hline Total & $\mathbf{1 , 3 2 E + 0 1}$ & $\mathbf{1 0 0} \%$ & $\mathbf{5 , 1 8 E + 0 1}$ & $\mathbf{1 0 0} \%$ \\
\hline
\end{tabular}

Para ambos os produtos, o consumo de água de rio foi o aspecto ambiental de maior relevância. No caso do HIPS fóssil, este consumo está atrelado à água utilizada como mecanismo de troca térmica nos processos de produção de poliestireno, refino de petróleo e manufatura de polibutadieno, os quais representaram $83,6 \%, 7,6 \%$ e 5,7\% da carga ambiental, respectivamente.

Já para o HIPS parcialmente renovável, o cultivo de cana-de-açúcar contribui com $93,4 \%$ do consumo de água, sendo que os demais processos anteriormente mencionados para o HIPS fóssil totalizam apenas 1,8\% da carga ambiental neste sistema de produto.

\subsubsection{Depleção de Recurso Fóssil}

$\mathrm{Na}$ categoria de depleção de recurso fóssil, o HIPS parcialmente renovável obteve 95,5\% da carga de impacto se comparado com o HIPS fóssil, mantendo o mesmo percentual identificado para o GPPS. A Tabela100 discrimina a representatividade dos aspectos ambientais compreendidos nesta categoria. 
Tabela 100: Principais aspectos ambientais contribuintes para a categoria de Depleção de Recurso Fóssil na produção de HIPS

\begin{tabular}{|c|c|c|c|c|}
\hline \multirow{2}{*}{ Aspecto Ambiental } & \multicolumn{2}{|c|}{ HIPS Fóssil } & \multicolumn{2}{|c|}{$\begin{array}{l}\text { HIPS parcialmente } \\
\text { renovável }\end{array}$} \\
\hline & $\begin{array}{c}\text { Quantidade } \\
{\left[\mathrm{m}^{3}\right]}\end{array}$ & $\begin{array}{c}\text { Contribuição } \\
\text { [\%] }\end{array}$ & $\begin{array}{c}\text { Quantidade } \\
{\left[\mathrm{m}^{3}\right]}\end{array}$ & $\begin{array}{c}\text { Contribuição } \\
{[\%]}\end{array}$ \\
\hline Petróleo cru & $6,00 \mathrm{E}+02$ & $64,3 \%$ & $5,64 \mathrm{E}+02$ & $63,1 \%$ \\
\hline Gás Natural & $3,29 E+02$ & $35,2 \%$ & $3,21 \mathrm{E}+02$ & $36,0 \%$ \\
\hline Outros & $5,28 \mathrm{E}+00$ & $0,6 \%$ & $7,80 \mathrm{E}+00$ & $0,9 \%$ \\
\hline Total & $9,34 \mathrm{E}+02$ & $100 \%$ & $8,92 E+02$ & $100 \%$ \\
\hline
\end{tabular}

O consumo de petróleo no processo de extração onshore, associado ao seu refino e incorporação no produto final compreendem $63,7 \%$ da depleção deste recurso para o HIPS fóssil e 62,4\% da carga ambiental para o HIPS parcialmente renovável.

De forma complementar, a extração, processamento e consumo de gás natural correspondem a cerca de 35\% dos aspectos ambientais para o HIPS fóssil e verde, respectivamente.

Tal como mencionado para o GPPS, a diferença entre a depleção do recurso fóssil para os poliestirenos de alto impacto é resultado da substituição deste insumo por matéria-prima renovável, o que justifica o melhor desempenho do HIPS verde.

\subsection{ANÁLISE COMPARATIVA ENTRE OS POLIESTIRENOS FÓSSEIS E PARCIALMENTE RENOVÁVEIS - INDICADOR ENDPOINT}

Com o intuito de averiguar, por meio de um indicador único, o perfil de desempenho dos produtos analisados por este trabalho, foi realizada a avaliação de impacto a partir do método ReCiPe Endpoint $(H)$ v. 1.07. Neste caso, as categorias de impacto quantificadas na etapa de caracterização foram normalizadas e ponderadas, de acordo com o modelo World Recipe $\mathrm{H} / \mathrm{H}$, bem como agregadas na forma de um único indicador.

Os resultados desta atividade estão apresentados nas Tabelas 101 e 102 para o GPPS e HIPS de origem fóssil e parcialmente renovável, respectivamente. 
Tabela 101: Resultados da Avaliação de Impacto, em nível endpoint, para o GPPS fóssil e parcialmente renovável.

\begin{tabular}{lccc}
\hline Categorias de Impacto & Unidades & GPPS Fóssil & $\begin{array}{c}\text { GPPS parcialmente } \\
\text { renovável }\end{array}$ \\
\hline Mudanças Climáticas (MC) & pts & $4,86 \mathrm{E}+01$ & $1,12 \mathrm{E}+02$ \\
\hline Depleção da Camada de Ozônio (DO) & pts & $3,30 \mathrm{E}-02$ & $3,10 \mathrm{E}-02$ \\
\hline Acidificação Terrestre (AT) & pts & $1,00 \mathrm{E}-02$ & $2,47 \mathrm{E}+00$ \\
\hline Eutrofização de Água Doce (EU) & pts & $0,00 \mathrm{E}+00$ & $1,00 \mathrm{E}-03$ \\
\hline Toxicidade Humana (TH) & pts & $1,20 \mathrm{E}+00$ & $1,76 \mathrm{E}+00$ \\
\hline Formação de Oxidantes Fotoquímicos (OF) & pts & $9,00 \mathrm{E}-03$ & $1,50 \mathrm{E}+00$ \\
\hline Formação de Material Particulado (MP) & pts & $7,01 \mathrm{E}+00$ & $3,53 \mathrm{E}+03$ \\
\hline Ecotoxicidade Terrestre (ET) & pts & $6,00 \mathrm{E}-03$ & $3,80 \mathrm{E}-02$ \\
\hline Ecotoxicidade Aquática (EA) & pts & $1,00 \mathrm{E}-03$ & $1,00 \mathrm{E}-03$ \\
\hline Ocupação de Solo Agricultável (SA) & pts & $0,00 \mathrm{E}+00$ & $1,70 \mathrm{E}+01$ \\
\hline Transformação de Áreas Naturais (AN) & pts & $1,02 \mathrm{E}-01$ & $9,50 \mathrm{E}-02$ \\
\hline Depleção de Recurso Fóssil (DF) & pts & $2,12 \mathrm{E}+02$ & $2,02 \mathrm{E}+02$ \\
\hline Total & Pts & $2,69 \mathrm{E}+02$ & $3,87 \mathrm{E}+03$ \\
\hline
\end{tabular}

Tabela 102: Resultados da Avaliação de Impacto, em nível endpoint, para o HIPS fóssil e parcialmente renovável.

\begin{tabular}{lccc}
\hline Categorias de Impacto & Unidades & GPPS Fóssil & $\begin{array}{c}\text { GPPS parcialmente } \\
\text { renovável }\end{array}$ \\
\hline Mudanças Climáticas (MC) & pts & $5,47 \mathrm{E}+01$ & $1,13 \mathrm{E}+02$ \\
\hline Depleção da Camada de Ozônio (DO) & pts & $2,90 \mathrm{E}-02$ & $2,70 \mathrm{E}-02$ \\
\hline Acidificação Terrestre (AT) & pts & $1,30 \mathrm{E}-02$ & $2,29 \mathrm{E}+00$ \\
\hline Eutrofização de Água Doce (EU) & pts & $0,00 \mathrm{E}+00$ & $1,00 \mathrm{E}-03$ \\
\hline Toxicidade Humana (TH) & pts & $1,11 \mathrm{E}+00$ & $1,63 \mathrm{E}+00$ \\
\hline Formação de Oxidantes Fotoquímicos (OF) & pts & $9,00 \mathrm{E}-03$ & $1,39 \mathrm{E}+00$ \\
\hline Formação de Material Particulado (MP) & pts & $8,92 \mathrm{E}+00$ & $3,27 \mathrm{E}+03$ \\
\hline Ecotoxicidade Terrestre (ET) & pts & $6,00 \mathrm{E}-03$ & $3,51 \mathrm{E}-01$ \\
\hline Ecotoxicidade Aquática (EA) & pts & $1,00 \mathrm{E}-03$ & $1,00 \mathrm{E}-03$ \\
\hline Ocupação de Solo Agricultável (SA) & pts & $0,00 \mathrm{E}+00$ & $1,57 \mathrm{E}+01$ \\
\hline Transformação de Áreas Naturais (AN) & pts & $8,70 \mathrm{E}-02$ & $8,10 \mathrm{E}-02$ \\
\hline Depleção de Recurso Fóssil (DF) & pts & $1,89 \mathrm{E}+02$ & $1,81 \mathrm{E}+02$ \\
\hline Total & Pts & $2,54 \mathrm{E}+02$ & $3,59 \mathrm{E}+03$ \\
\hline
\end{tabular}

Observa-se, segundo esta perspectiva, que a adoção de ativo renovável nos processos de manufatura do GPPS e do HIPS propiciou em um índice global desfavorável, cuja constatação pode ser verificada mediante os gráficos 7 e 8 . 


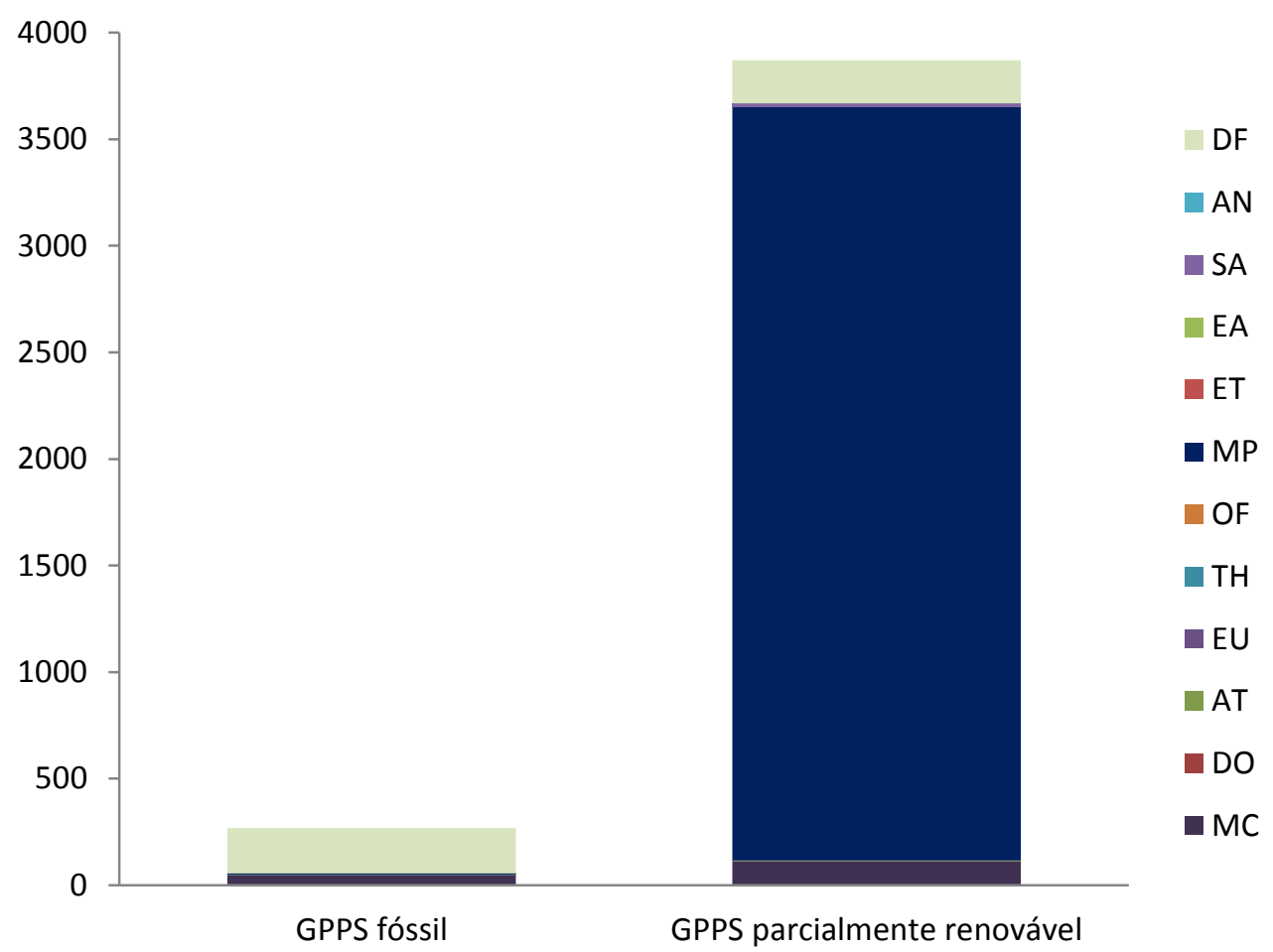

Gráfico 7: Avaliação de Impacto, em nível endpoint, para o GPPS fóssil e parcialmente renovável.

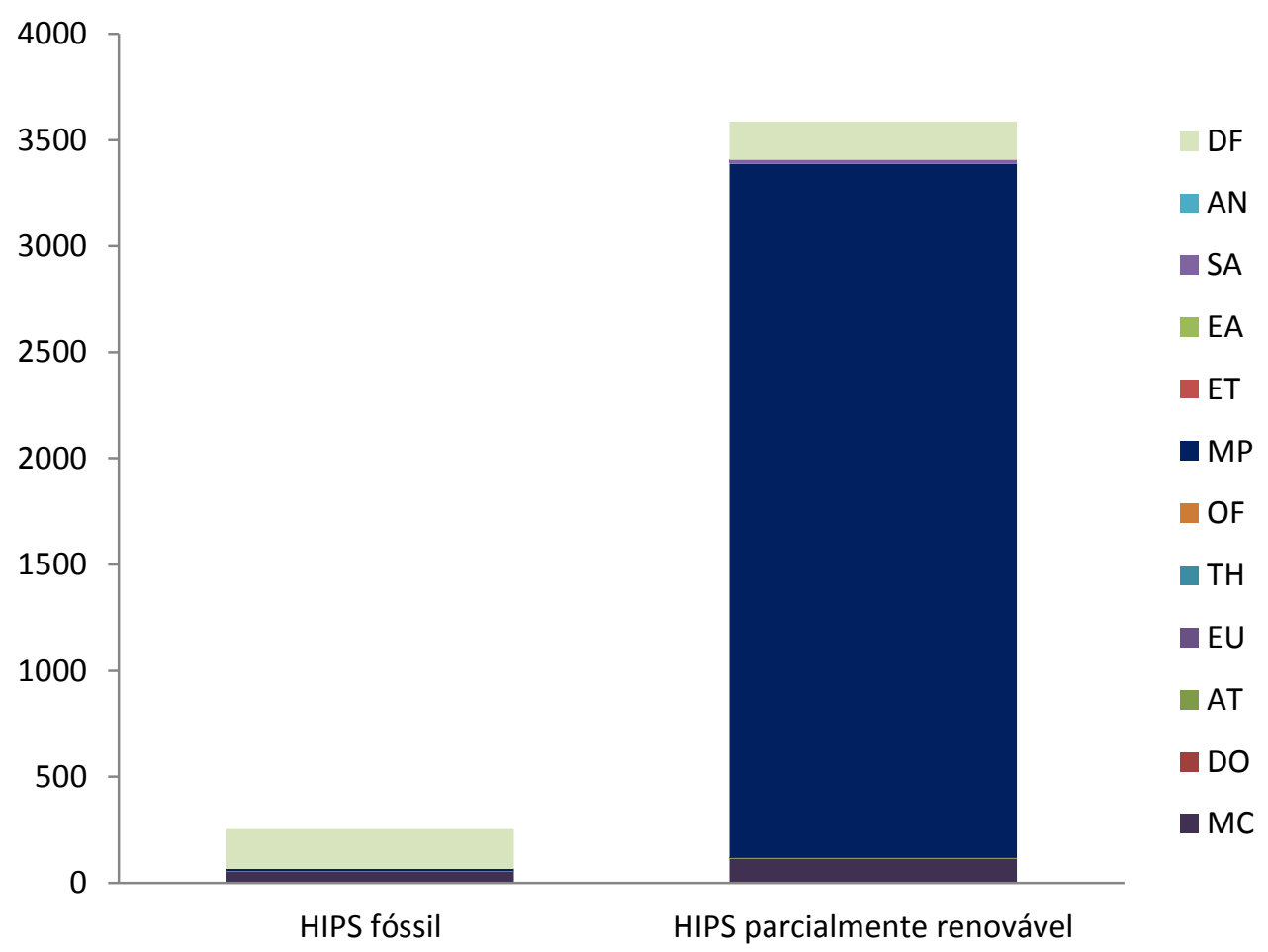

Gráfico 8: Avaliação de Impacto, em nível endpoint, para o HIPS fóssil e parcialmente renovável.

De forma comparativa à avaliação em nível midpoint, é possível averiguar que este resultado está em grande parte associado à emissão de material particulado, cuja origem está nas atividades de cultivo e plantação de cana-de-açúcar. 
Ainda, as características dos perfis ambientais obtidos pelo método ReCiPe Endpoint (H) v. 1.07 corroboram com aquelas encontradas em nível midpoint. Isto é verificado, uma vez que as diferenças de magnitude das categorias de impacto antes identificadas se mantiveram para os GPPS e HIPS.

Cabe destacar que os resultados ora indicados são válidos tão somente para as condicionantes estabelecidas neste estudo, tais como: fronteiras do sistema, fonte dos dados, critério de alocação, coberturas geográficas e temporais, entre outras. 


\section{CONSIDERAÇÕES FINAIS}

Os benefícios efetivos da substituição de eteno de origem fóssil por aquele obtido a partir de matéria-prima renovável, na produção de GPPS e HIPS, foram identificados em três das treze categorias de impacto avaliadas, quais sejam: depleção da camada de ozônio, transformação de áreas naturais e depleção de recurso fóssil.

Este resultado está diretamente relacionado a redução do consumo de recurso fóssil, nacional e importando, bem como no menor uso de energia elétrica no sistema de produto do GPPS e HIPS parcialmente renováveis, em decorrência da adoção de biomassa nas unidades de produção de etanol.

Por outro lado, maiores impactos foram identificados para as categorias de: mudanças climáticas; acidificação terrestre; eutrofização; toxicidade humana; formação de material particulado; formação de oxidantes fotoquímicos; ecotoxicidade terrestre; ecotoxicidade aquática; ocupação de solo agricultável e depleção de água. Tal condição está atrelada às características do processo de cultivo e plantação de canade-açúcar, no qual às atividades de queima e uso de fertilizantes e defensivos agrícolas aportaram em diferentes emissões de poluentes para o ar, o solo e a água. No que tange à comparação em nível endpoint, no qual os impactos são expressos em indicador único, verifica-se que a formação de material particulado é responsável pela maior contribuição negativa nos perfis de desempenho do HIPS e GPPS parcialmente renováveis. A representatividade desta categoria de impacto é de exatos $91 \%$ para ambos os produtos.

Nesse sentido, a melhoria no processo de colheita da cana-de-açúcar, por meio da redução das queimadas, pode ser uma das estratégias tecnicamente viáveis para melhorar a condição de impacto verificada para estes polímeros. A influência desta alternativa pode ser parte integrante de trabalhos de pesquisa futuros.

Ressalta-se, ainda, que tecnologias mais eficientes para a produção de etanol poderiam ser aplicadas com enfoque em otimizar a geração de energia elétrica a partir da queima de resíduos de biomassa. Em consequência desta ação, parte da energia excedente do processo seria integrada à rede de distribuição nacional, ocasionando na venda de um terceiro produto, além do etanol e do açúcar já quantificados para este sistema. 
Nesse sentido, pesquisas voltadas a análises da extensão de medidas de produção mais limpa trabalhariam na identificação das melhorias no perfil de desempenho ambiental do GPPS e HIPS parcialmente renováveis, avaliando os efeitos da alocação para este cenário.

Sobre a unidade de desidratação de etanol nos sistemas de produto dos poliestirenos derivados de eteno renovável, constata-se que esta contribui em diferentes impactos ambientais, seja pelo elevado consumo de energia térmica requerido no processo, seja pelas características dos modais de transporte. Por esta razão, as diferenças absolutas entre as categorias com melhor desempenho nestes polímeros não ultrapassaram $10 \%$ dos valores averiguados para os produtos de origem exclusivamente fóssil.

Assim, as vulnerabilidades decorrentes do processamento de etanol em eteno, do sistema de transporte adotado para a transferência de etanol e das unidades de utilidades desta etapa, deveriam necessariamente ser esgotadas quanto da realização de estudos específicos.

No que se refere às mudanças climáticas, o lançamento de poluentes atmosféricos durante o tratamento do solo para o cultivo de biomassa adicionado, mais uma vez, dos aspectos resultantes das atividades de queimada na colheita da cana-de-açúcar, foram fundamentais para que GPPS e HIPS parcialmente renováveis representassem mais que o dobro das emissões de gases efeito estufa se comparado aos poliestirenos de origem fóssil.

Em relação aos processos elementares em comum entre os sistemas de produto, cabe salientar que a importação de petróleo acarretou no acréscimo de carga ambiental para o perfil de desempenho tanto do GPPS quanto do HIPS. Estas emissões estão associadas às tecnologias de extração aplicadas nos países de importação, às características da matriz energética desses mesmos locais, bem como às perdas e consumos de combustíveis durante o transporte do insumo. Portanto, recomenda-se que novas iniciativas de trabalhos avaliem a interferência do percentual de importação de petróleo no desempenho ambiental dos bens contemplados por esta pesquisa.

No que diz respeito aos GPPS e HIPS fósseis, o consumo, processamento e transporte de gás natural foram atividades reincidentes em impactos como: mudanças climáticas, acidificação terrestre, formação de oxidantes fotoquímicos, formação de material particulado e depleção de recurso fóssil. 
Este insumo está presente no processo de manufatura destes produtos na forma de combustível para a geração de calor e de matéria-prima para a constituição de eteno. Desta maneira, os benefícios identificados para o GPPS e HIPS renováveis estão vinculados, também, ao menor consumo deste material.

Conclui-se, assim, que a substituição de recursos fósseis por renováveis é válida em situações específicas, nas quais são identificadas a escassez de petróleo e seus derivados. Além disso, esforços nas áreas de engenharia genética e produção devem ser verificados para a melhoria dos sistemas que envolvem a produção e transformação de cana-de-açúcar, a fim a consolidar tecnologias e aprimorar os perfis de desempenho do GPPS e HIPS parcialmente renováveis. 


\section{REFERÊNCIAS BIBLIOGRÁFICAS}

ABIQUIM - ASSOCIAÇÃO BRASILEIRA DA INDÚSTRIA QUÍMICA. Anuário da Indústria Química Brasileira: 2009. São Paulo: ABIQUIM, 2010.

ABIQUIM - ASSOCIAÇÃO BRASILEIRA DA INDÚSTRIA QUÍMICA. Anuário da Indústria Química Brasileira: 2010. São Paulo: ABIQUIM, 2011.

ABNT - ASSOCIAÇÃO BRASILEIRA DE NORMAS TÉCNICAS. NBR ABNT NBR ISO 14040. Gestão Ambiental, Avaliação do Ciclo de Vida: definição de objetivo e escopo e Analise de Inventario. São Paulo: ABNT, 2009.

ABNT - ASSOCIAÇÃO BRASILEIRA DE NORMAS TÉCNICAS. NBR ABNT NBR ISO 14044. Gestão Ambiental, Avaliação do Ciclo de Vida: requisitos e orientações. São Paulo: ABNT, 2009.

ACC - PLASTICS DIVISION OF THE AMERICAN CHEMISTRY COUNCIL. Cradleto-gate life cycle inventory of nine plastic resins and four polyurethane precursors. Kansas: Franklin Associates, 2011.

ALMEIDA, A. S. de P. N. Simulação de reatores de polimerização de estireno: modelagem cinética e termodinâmica. 2004. 186 p. Dissertação (Mestrado) Escola de Engenharia, Universidade Federal do Rio Grande do Sul, 2004.

ALMEIDA, A. S.; WADA, K.; SECCHI, A. R. Simulation of styrene polymerization reactors: kinetic and thermodynamic modeling. Brazilian Journal of Chemical Engineering, v. 25, n.2, p. 337-349, abril - junho 2008.

ALMEIDA, J. Introdução à Indústria do Petróleo. Rio Grande: FURG - CTI, 2006.

ALVARENGA, R. A. F. Avaliação de métodos de AICV: um estudo de caso de quatro cenários de ração para frangos de corte. 2010. 158 p. Dissertação (Mestrado) - Programa de Pós-graduação em Engenharia Ambiental, Universidade Federal de Santa Catarina, Florianópolis, 2010.

ANP - AGÊNCIA NACIONAL DE PETRÓLEO. Anuário estatístico brasileiro do petróleo, gás natural e biocombustíveis: 2010. Rio de Janeiro: ANP, 2010.

ANP - AGÊNCIA NACIONAL DE PETRÓLEO. Anuário estatístico brasileiro do petróleo, gás natural e biocombustíveis: 2012. Rio de Janeiro: ANP, 2012.

ANP - AGÊNCIA NACIONAL DE PETRÓLEO. Anuário estatístico brasileiro do petróleo, gás natural e biocombustíveis: 2011. Rio de Janeiro: ANP, 2011.

ANP - AGÊNCIA NACIONAL DE PETRÓLEO. Autorizações de Operação concedidas a dutos. 2012.

Disponível em:

www.anp.gov. $\cdot$ r $/$ ?pg $=14450 \& \mathrm{~m}=\& \mathrm{t} 1=\& \mathrm{t} 2=\& \mathrm{t} 3=\& \mathrm{t} 4=\& \mathrm{ar}=\& \mathrm{ps}=\&$ cachebust $=13495380$

77983. Acesso em: 27 de fevereiro de 2012. 
ANP - AGÊNCIA NACIONAL DE PETRÓLEO. Esquemas de produção no refino de petróleo. 2012.

Disponível em:

www.anp.gov.br/?pg=7854\&m=\&t1=\&t2=\&t3=\&t4=\&ar=\&ps=\&cachebust $=139485252$ 41. Acesso em: 27 de fevereiro de 2012.

ANTUNES, A. Setores da indústria química orgânica. Rio de Janeiro: E-papers, 2007. $242 \mathrm{p}$.

ARAUJO, M. A. R. Avaliação de desempenho de artefato de poliestireno de alto impacto reciclado. 2006. 87 p. Dissertação (Mestrado) - Instituto de Química, Universidade do Estado do Rio de Janeiro, Rio de Janeiro, 2006.

AYARZA, J. A. C. Alternativa para aumentar a produção mundial do etanol anidro combustível no curto prazo: o potencial dos méis da cana. 2007. 137 p. Dissertação (Mestrado) - Faculdade de Engenharia Mecânica, Universidade Estadual de Campinas, Campinas, 2007.

BACKES, D. Análise e Perspectivas de Mercado do Butadieno. 2011. 30 p. Trabalho de Diplomação (Engenharia Química) - Departamento de Engenharia Química, Universidade Federal do Rio Grande do Sul. Porto Alegre, 2011.

BAPTISTA, A.L.M.C; PINHO R.A; GILBERT R.W. Processo para Maximização de Destilados Médios de FCC com a Produção de Insumos Petroquímicos e Máxima Rentabilidade. PI 0605009-3, Rio de Janeiro, 2006.

BARROCAS, H. V., LACERDA, A. I. Processo para a produção de eteno a partir de etanol de álcool etílico. Instituto Nacional de Propriedade Industrial: Patente 0601803-3 A, 2006.

BARROCAS, H. V., SILVA, J. B., ASSIS, R. C. Process for preparing ethene. United States Patent: Patente 4.232.179, 1980.

BAUMANN H.; TILLMAN A. M. The hitch hiker's guide to LCA. Suécia: Studentlitteratur AB, 2004.

BERECHE, R. P. Modelagem e integração energética do processo de produção de etanol a partir de biomassa de cana-de-açúcar. 2011. 262 p. Tese (Doutorado) - Faculdade de Engenharia Mecânica, Universidade Estadual de Campinas, Campinas, 2011.

BNDES - BANCO NACIONAL DE DESENVOLVIMENTO ECONÔMICO E SOCIAL. Bioetanol de cana-de-açúcar: energia para o desenvolvimento sustentável. Rio de Janeiro: BNDES, 2008.

BORRELLY, D. F. Estudo comparativo da degradação de poliestireno e de poliestireno de alto impacto por envelhecimentos natural e artificial. 2002. 90 p. Dissertação (Mestrado) - Escola Politécnica, Universidade de São Paulo, São Paulo, 2002. 
BRASKEM. Braskem inicia recebimento de etanol por ferrovia. Disponível em http://www3.braskem.com.br/site/portal_braskem/pt/sala_de_imprensa/sala_de_impr ensa_detalhes_10269.aspx. Acesso em: 27 Janeiro 2013.

BURRI, D. R. et. al. Oxidative dehydrogenation of ehtylbenzene to styrene with $\mathrm{CO} 2$ over SnO2-ZrO2 mixed oxide nanocomposite catalysts. Catalysis Today, $\mathrm{n}$ 131, p. 173-178, 2008.

CAMERON, et. al. Process Design for the Production of Ethylene from Ethanol. Pennsylvania: University of Pennsylvania, 2012.

CETESB - COMPANHIA AMBIENTAL DO ESTADO DE SÃO PAULO. Emissões de Gases SF6. São Paulo: CETESB, 2011.

CGEE - CENTRO DE GESTÃO E ESTUdOS ESTRATÉGICOS. Bioetanol combustível: uma oportunidade para o Brasil. Brasília: CGEE, 2009.

CHEHEBE, J. R. B. Análise do ciclo de vida de produtos: ferramenta gerencial da ISO 14000. Rio de Janeiro: Qualitymark, 2002.

$\mathrm{CHEN}, \mathrm{G}$. et. al. Catalytic dehydration of bioethanol to ethylene over $\mathrm{TIO2} / \mathrm{v}-$ AL2O3 catalysts in microchannel reactors. Catalysis Today, n 125, p. 111-119, 2007.

CMAI - CHEMICAL MARKETS ASSOCIATES INC. 2011 World Styrene Analysis (WSA). Texas: CMAl, 2011.

CNI - CONFEREÇÃO NACIONAL DA INDÚSTRIA. A Indústria e o Brasil - gás natural: uma proposta política para o Brasil. Brasília: CNI, 2010

CONAB - COMPANHIA NACIONAL DE ABASTECIMENTO. Acompanhamento da safra brasileira: cana-de-açúcar safra 2008/2009. Brasília: Conab, 2008.

CONAB - COMPANHIA NACIONAL DE ABASTECIMENTO. Perfil do Setor do açúcar e do etanol no Brasil: safra 2010/2011. Brasília: Conab, 2013.

CONAB - COMPANHIA NACIONAL DE ABASTECIMENTO. Acompanhamento da safra brasileira: cana-de-açúcar safra 2010/2011. Brasília: Conab, 2011.

COSTA, M. P. M. Estudo da tenacificação do poliestireno com elastômeros butadiênicos. 2002. 127 p. Dissertação (Mestrado) - Instituto de Química, Universidade do Estado do Rio de Janeiro, Rio de Janeiro, 2009.

DIAS, M. O. S. Desenvolvimento e otimização de processos de produção de etanol de primeira e segunda geração e eletricidade a partir de cana-de-açúcar. 2011. 253 p. Tese (Doutorado) - Faculdade de Engenharia Química, Universidade Estadual de Campinas, Campinas, 2011. 
ECOINVENT CENTRE - Swiss Centre for Life Cycle Inventories. Implementation of Life Cycle Impact Assessment Methods. Ecoinvent Report 3. Dübendorf, 2007.

EPA - ENVIRONMENTAL PROTECTION AGENCY. Organic Chemical Process Industry. 1995. Disponível em: http://www.epa.gov/ttn/chief/ap42/ch06/final/c06s063.pdf. Acesso em: 15 fevereiro 2012.

EPE - EMPRESA DE PESQUISA ENERGÉTICA. Balanço Energético Nacional 2012: Ano Base 2011. Rio de Janeiro, 2012.

FAHIN, M.; AL-ALSAHHAF, T.; ELKILANI, A. Introdução ao Refino de Petróleo. Rio de Janeiro: Elsevier, 2012. 457 p.

FERREIRA, J. V. R. Análise do Ciclo de Vida de Produtos. Viseu: Instituto Politécnico de Viseu, 2004.

FORTE, M. M. C.; DAL PIZZOL, M. F. Aspectos morfológicos e relação estrutura - propriedades de poliestireno de alto impacto. Polímeros: Ciência e Tecnologia, v. 11, n.3, p. 158-168, 2001.

GASNET. Gasodutos em operação.

Disponível em: http://www.gasnet.com.br/novo_gasoduto/operacao.asp. Acessado em: 19 de Janeiro de 2013.

GLOBAL BUSINESS INTELLIGENCE. Polystyrene (PS) and Expandable Polystyrene (EPS) Global Market to 2020.

Disponível em:

www.marketresearch.com/GBI-Research-v3759/Polystyrene-PS-Expandable-EPSGlobal-6744076. Acesso em: 31 maio 2012.

GOEDKOOP, M., et. al. ReCiPe 2008 - a life cycle assessment method which comprises harmonized category indicators at the midpoint and endpoint level. First Edition. Netherlands: Ministerie van Volkshuisvesting, 2013.

GOMES, G. L. Análise da integração refino-petroquímica: oportunidades econômicas, estratégicas e ambientais. 2011. 268 p. Tese (Doutorado) - COPPE, Universidade Federal do Rio de Janeiro, Rio de Janeiro, 2011.

GRASSI, G. V; DAL PIZZOL, M. F. Caracterização morfológica do poliestireno de alto impacto (HIPS). Polímeros: Ciência e Tecnologia, v. 18, n.13, p. 12-19, 2008.

GREET - Greenhouse Gases, Regulated Emissions, and Energy Use in Transportation, version 1.8d. Argonne National Laboratory. Argonne, Illinois, USA, 2010.

GRISOLI, R. P. S. Comparação das emissões de gases de efeito estufa no ciclo do etanol de cana-de-açúcar no Brasil e os critérios de Diretiva Europeia para Energias Renováveis. 110 p. Dissertação (Mestrado) - PPGE, Universidade de São Paulo, 2011. 
GUINEE, J. B. et. al. Life Cycle Assessment: an operational guide to the ISO Standards. Final Report. Leidein University, 2001.

HOLTZ, R. D. Obtenção de catalisadores de vanádio e magnésio suportados em carvão ativado para a produção de estireno. 2008. 111 p. Dissertação (Mestrado) - Instituto de Química, Universidade Federal da Bahia, Salvador, 2008.

HOSSAIN, M. M. Kinetics modeling of ethylbenzene dehydrogenation to styrene over a mesoporous alumina supported iron catalyst. Chemical Engineering Journal, 1-14, 2012. Disponível em: http://dx.doi.org/10.1016/j.cej.2012.06.108.

IPCC - INTERGOVERNMENTAL PANEL ON CLIMATE CHANGE. Guidelines for national greenhouse gas inventories, Vol. 4 - Agriculture, forestry and other land use. Intergovernmental Panel on Climate Change, 2006.

JENSEN, A. A., et. al. Life Cyle Assessment: a guide to approaches, experiences and information sources. United Kingdom: European Environment Agency, 1997.

KRIK, R.; OTHMER, D. F. Encyclopedia of Chemical Tecnology. 5th. New Jersey:John Wiley \& Sons, Inc., 2007.

KULAY, L. A. Uso da análise de ciclo de vida para comparação do desempenho ambiental das rotas úmida e térmica de produção de fertilizantes fosfatados. 2004. 314 p. Tese (Doutorado em Engenharia Química) - Escola Politécnica, Universidade de São Paulo, São Paulo.

LANXESS ELASTOMEROS DO BRASIL S.A. Nossas unidades no Brasil. Disponível em:

http://lanxess.com.br/at-a-glance-brazil/our-sites-in-brazil/?L=3. Acesso em: 07 janeiro 2013.

LEITE, H. E. B.; OLIVEIRA, A. C.; RANGEL, M C. Ação promotora do zinco em catalisadoes de síntese do estireno. Química Nova, v. 27, n.2, p. 247-250, 2004.

LIMA, A. M. Estudo termodinâmico, cinético e otimização da produção de etileno a partir de etanol em alumina e óxido misto de cério-zircônio. 2010. 106 p. Dissertação (Mestrado) - Engenharia Química, Universidade Federal de Uberlândia, Minas Gerais, 2010.

MACEDO, I. C.; SEABRA, J. E. A.; SILVA, J. E. A. R. Greenhouse gases emissions in the production and use of ethanol from sugarcane in Brazil: The 2005/2006 averages and a prediction for 2020. Biomass \& Energy, v. 32, p. 582-595, 2008.

MADIVAL,S. et. al. Assessment of the environmental profile of PLA, PET and PS clamshell containers using LCA methodology. Journal of Cleaner Production, $\mathrm{n}$. 17, 1183-1194, 2009.

MARIANO, J. B. Impactos ambientais do refino de petróleo. 2001. 279 p. Dissertação (Mestrado) - COPPE, Universidade Federal do Rio de Janeiro, Rio de Janeiro, 2001. 
MARQUES, J. J. O plástico "verde" e o mercado brasileiro de etanol. 2010. 143 p. Dissertação (Mestrado) - Faculdade de Economia, Administração e Contabilidade, Universidade de São Paulo, São Paulo, 2010.

MARTINS, A. T. Projeto de um controlador PI-MIMO para uma planta de produção de poliestireno. 2009. 98 p. Dissertação (Mestrado) - Escola de Engenharia, Universidade Federal do Rio Grande do Sul, Porto Alegre, 2009.

MDIC - Ministério do Desenvolvimento, Indústria e Comércio Exterior. Sistema AliceWeb. Disponível em: < http://aliceweb.desenvolvimento.gov.br/>. Acesso em: 9 novembro 2011.

MELO, C. A. A expansão do sistema de distribuição de gás natural no Brasil: a dinâmica dos investimentos, da renda e das emissões de $\mathrm{CO}_{2}$. 2005. 81p. Dissertação (Mestrado) - Faculdade de Engenharia Mecânica, Universidade Estadual de Campinas, Campinas, 2005.

MHE - MINISTERIO DE HIDROCARBUROS Y ENERGÍA. Balance Energético Departamental de Bolivia 2010. La Paz: MHE, 2010.

MONTEIRO, M. F. Avaliação do Ciclo de Vida do fertilizante superfosfato simples. 2008. 177 p. Dissertação (Mestrado) - Escola Politécnica, Universidade Federal da Bahia. Salvador, 2008.

MORSCHBACKER, A. Bio-ethanol based ethylene. Journal of Polymer Reviews, v.49, n. 2, p. 79-84, 2009.

MOURAD, A. L.; GARCIA, E. E.; VILHENA, A. Avaliação do ciclo de vida: princípios e aplicações. Campinas: CETEA;ITAL, 2002.

NETZER, D. Benzene supply trends and proposed method for enhanced recovery. In: 2005 WORLD PETROCHEMICAL CONFERENCE, 2005, Houston. Disponível em:http://www.petrochemicals.dnetzer.net/articles/article-3.05.pdf. Acesso em: 17 janeiro 2012.

NOVAES, M. R. Análise da redução da queima na colheita da cana-de-açúcar por meio da modelagem dinâmica espacial. 2010. 153 p. Dissertação (Mestrado) Instituto Nacional de Pesquisas Espaciais, São José dos Campos, 2010.

NUNES, D. S. S.; COUTINHO, F. M. B.; MELLO, I. L. Principais aspectos da polimerização do 1,3-butadieno. Polímeros: Ciência e Tecnologia, v. 15, n. 4, p. 296305, 2005.

ODIAN, G. G. Principles of polymerization. 4th Ed. New Jersey: John Wiley \& Sons, Inc., 2004.

OLIVEIRA, A. C. et al. Efeito do cromo nas propriedades catalíticas da MCM-41. Química Nova, v. 28, n.1, p. 37-41, 2005. 
PASSUELO, A. C. B. Aplicação da Avaliação do Ciclo de Vida em embalagens descartáveis para frutas: estudo de caso. 2007. Dissertação (Mestrado) Programa de Pós-graduação em Recursos Hídricos e Saneamento Ambiental, Universidade do Rio Grande do Sul, Porto Alegra, 2007.

PEREIRA, R. A. Análise dos principais processos críticos para produção de insumos petroquímicos e sua evolução tecnológica. 2010. 146 p. Dissertação (Mestrado) - Escola de Química, Universidade Federal do Rio de Janeiro, Rio de Janeiro, 2010.

PEREIRA, R. A. et al. Tendências Tecnológicas e mercadológicas dos principais produtos petroquímicos básicos: eteno e propeno. In: CONGRESSO BRASILEIRO DE PESQUISA E DESENVOLVIMENTO EM PETRÓLEO E GÁS, 4, 2007, São Paulo. Anais... São Paulo: PDPETRO, 2007. p. 21-24.

PEREIRA, S. W. Análise ambiental do processo produtivo de pisos cerâmicos: Aplicação de avaliação do ciclo de vida. 2004. 122 p. Dissertação (Mestrado) Centro Tecnológico, Universidade Federal de Santa Catarina, Florianópolis, 2004.

PETROBRAS. Processos de Refino. Curitiba: Petrobrás, 2002.

PINHO, A. et. al. Renewable Raw Materials for fuel and petrochemicals production. In: World Petroleum Congress, 2008.

PLASTICSEUROPE. Environmental Producti Declaration of the European Plastics Manufacters: polysterene. Belgium: PlasticsEurope, 2008.

RIBEIRO, P. H. Contribuição ao banco de dados brasileiro para apoio à avaliação do ciclo de vida: fertilizantes nitrogenados. 2009. 343 p. Tese (Doutorado) - Escola Politécnica, Universidade de São Paulo, São Paulo, 2009.

SALAZAR, K. J. M. Uso de água e análise exergética na produção integrada de etanol de primeira e segunda geração a partir de cana-de-açúcar. 2012. 197 p. Dissertação (Mestrado) - Faculdade de Engenharia Mecânica, Universidade Estadual de Campinas, Campinas, 2012.

SANTOS, C. Prevenção à Poluição Industrial: Identificação de Oportunidades, Análise dos Benefícios e Barreiras. 2005. 287 p. Tese (Doutorado) - Escola de Engenharia de São Carlos, Universidade de São Paulo, São Carlos, 2005.

SANTO, E. M., et. al. Gás natural - estratégias para uma energia nova no Brasil. São Paulo: Annablume, 2002.

SCHUCHARDT U.; RIBEIRO, M; L. A indústria petroquímica no próximo século: como substituir o petróleo como matéria-prima?. Química Nova, v. 24, n.24, p. 247-251, 2001.

SCHUTTE, G. R. Elo Perdido: Estado, Globalização e Indústria Petroquímica no Brasil. São Paulo: Annablume, 2004. 259 p. 
SEABRA, J. E. A. Avaliação técnico-econômica de opções para aproveitamento integral da biomassa de cana no Brasil. 2008. 274 p. Tese (Doutorado) - Faculdade de Engenharia Mecânica, Universidade Estadual de Campinas, Campinas, 2008.

SEJIMO, W. N. Obtenção do álcool anidro. 2011. 45 p. Trabalho de Graduação (MBA em Tecnologia em Biocombustíveis) - Faculdade de Tecnologia de Araçatuba, Araçatuba, 2011.

SERFATY, M. E.; MONTENEGRO, R. S. P. Aspectos gerais do poliestireno. BNDES Setorial, Rio de Janeiro, n.16, p. 123-136, setembro 2002.

SILVA, G.A.; KULAY, L. A.: Avaliação do Ciclo de Vida. In: VILELA, A.; DEMAJOROVIC, J. Modelos e ferramentas de gestão ambiental: desafios e perspectivas para as organizações. São Paulo: Editora SENAC, 2006.

SOUSA, S. N. Normalização de critérios ambientais aplicados à avaliação do ciclo de vida. 2008. 73 p. Dissertação (Mestrado) - Engenharia Ambiental, Universidade Federal de Santa Catarina, Florianópolis, 2008.

SUGAWARA, E. T. Comparação dos desempenhos ambientais do B5 etílico de soja e do óleo diesel, por meio da Avaliação do Ciclo de Vida (ACV). 2012. 240 p. Dissertação (Mestrado) - Escola Politécnica, Universidade de São Paulo, São Paulo, 2012.

SUWANMANEE, $U$. et. al. Life cycle energy consumption and greenhouse gás emissions of polylactic acid (PLA) and polystyrene (PS) trays. Natural Science, $n$. 44, 703-716, 2010.

TALAVERA, R. M. R. Caracterização de sistemas, simulação e otimização de etapas da planta de processamento de gás natural. 2002. 154 p. Tese (Doutorado) - Faculdade de Engenharia Química, Universidade Estadual de Campinas, Campinas, 2002.

TAVARES, M. E. E. Análise do refino no Brasil: Estado e perspectivas - uma análise "cross-section". 2005. 384 p. Tese (Doutorado) - COPPE, Universidade Federal do Rio de Janeiro, Rio de Janeiro, 2005.

TGB - TRANSPORTADORA BRASILEIRA GASODUTO BOLÍVIA-BRASIL. O Gasoduto - características.

Disponível em:

http://www.tbg.com.br/portalTBGWeb/tbg.portal?_nfpb=true\&_pageLabel=pgCaracte risticasGasoduto. Acessado em 03 de Fevereiro de 2013.

TRANSPETRO. Relatório Anual 2010. Rio de Janeiro, 2010. Disponível em: www.transpetro.com.br/portugues/relatorio_anual/2010/pt-en/index.html. Acesso em: 23 março 2012.

UNEP - UNITED NATIONS ENVIRONMENT PROGRAMME. Global Guidance Principles for Life Cycle Assessment Databases: A basis for greener processes and products. Paris: United Nations Publication, 2011. 
ÚNICA - UNIÃO DA INDÚSTRIA DE CANA-DE-AÇÚCAR. Setor Sucroenergético Mapa de Produção. 2012.

Disponível em: www.unica.com.br/content/show.asp?cntCode= [D6C39D36-69BA458D-A95C-815C87E4404D/\}. Acessado em 14 junho 2012.

VIANNA, F. C. Análise de Ecoeficiência: Avaliação do desempenho econômicoambiental do biodiesel e petrodiesel. 2006. 183 p. Dissertação (Mestrado) - Escola Politécnica, Universidade de São Paulo, São Paulo, 2006.

WÜNSCH, J.R. Polystyrene: Synthesis, production and applications. United Kingdom: Rapra Technology Ltd., 2000.

ZABANIOTOU, A., KASSIDI, E. Life cycle assessment applied to egg packaging made from polystyrene and recycled paper. Journal of Cleaner Production, n. 11, 549-559, 2003. 